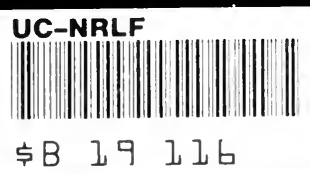

\$B 29 1 16 


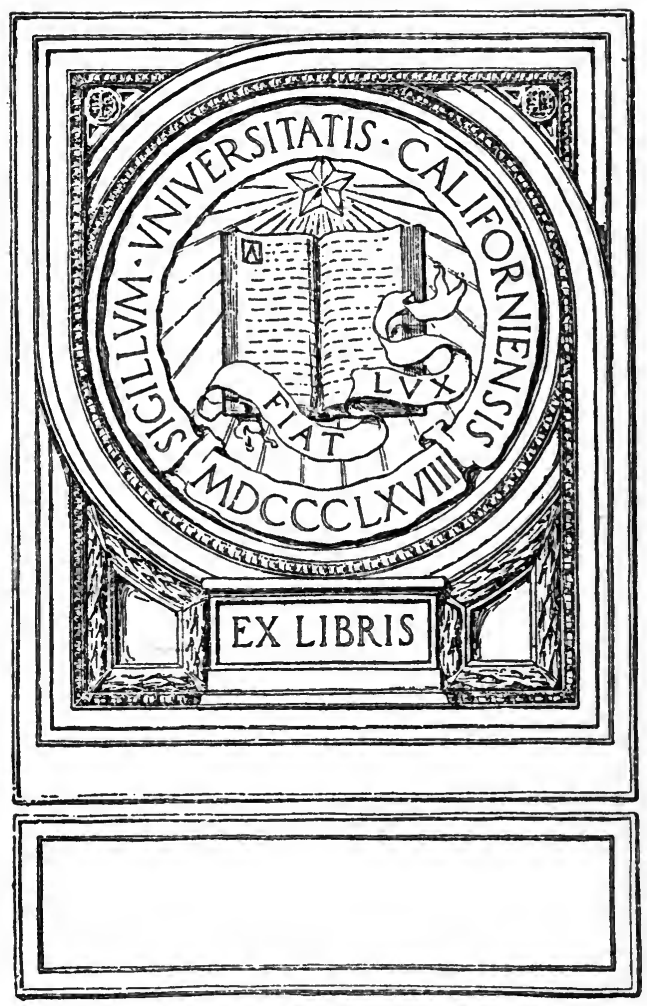


Digitized by the Internet Archive in 2007 with funding from Microsoft Corporation 


\section{THE PRINCIPLES OF ECONOMIC GEOGRAPHY}




\section{FROM THE SAME PUBLISHERS}

\section{ECONOMIC GEOGRAPIIY}

By John McFarlane, M.A., M.Com.,

Lecturer in Geography in the University of Manchester.

This important work will appeal with special force to all those who have recognized the necessity of organizing our teaching of commercial subjects on a more rational and scientific basis. The present volume will be found to be one of the most complete works on geographical science which has been produced.

In demy 8vo, cloth gilt, 568 pp., with illustrations, 10s. net.

London: Sir Isaac Pitman \& Sons, Ltd. 


\section{PITMAN'S ECONOMIC LIBRARY}

\section{THE PRINCIPLES OF}

$\mathrm{E} \mathrm{C}$
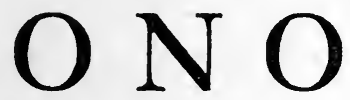

$M$

I

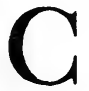

GEO G R A P H Y

BY

R. N. RUDMOSE BROWN, D.Sc.

Lecturer in Geography in the University of Sheffield

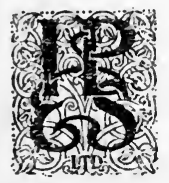

LONDON

SIR ISAAC PITMAN \& SONS, LTD. PARKER STREET, KINGSWAY, W.C.2 BATH, MELBOURNE, TORONTO, NEW YORK 


\section{HF1027 \\ 385}

Printed By

Sir Isaac Pitman \& Sons, Ltd.

Bath, ENGLAND 


\section{PREFACE}

THis volume attempts to give little more than an outline of the principles of economic geography in a readable form. The scope of the subject is liberally interpreted in the belief that the deeper and wider the foundations the surer the edifice that can be built. For this reason several matters are touched on which are not often dealt with in works on economic geography. Statistical matter, as far as possible, has been avoided as out of keeping with the aim of the book. Moreover, statistics for recent years, even when available, do not illustrate the normal features of production and trade, owing to the dislocation caused by the war.

It is hoped that the following chapters, by indicating that there is more in the subject than the description of places and their products, will help to justify the inclusion of economic geography in the higher branches of modern study. Properly understocd and appreciated, economic geography is a help in the solution of many of the political problems of the time.

The book should be read with the help of a good modern atlas, without which no volume on geography is complete.

It is impossible to acknowledge all the sources to which I am indebted, but the list of books at the end, although not exhaustive, includes the principal works consulted. It may be added that an intelligent use of the daily and pericdical press is the best way to keep abreast of developments in economic geography.

\section{R. N. RUDMOSE BROWN.}





\section{CONTENTS}

CHAP.

PAGE

PREFACE

InTRODUCTION-Scope of Economic Geography-Man and his Environment

I. The Physical Environment-Rocks and SoilsClimate

II. The Influence of Climate $\cdot \quad \cdot \quad \cdot \quad \cdot \quad \cdot \quad \cdot 9$

III. The Influence of Vegetation a $\quad \cdot \quad \cdot \quad \cdot \quad \cdot 16$

IV. The Influence of Animal life $\quad$ - $\quad$ • $\quad$ • 25

V. Some Important Crops-Food Crops and Stimulants . 34

VI. Some Important Crops-Industrial Crops . • . 49

VII. Live Stock and Animal Products • • . $\quad$. 56

VIII. The Distribution of Minerals . • . . . 61

IX. Sources of Mechanical Power . . . . . 72

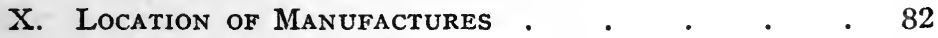

XI. The Distribution of Population • . . $\quad$ • 87

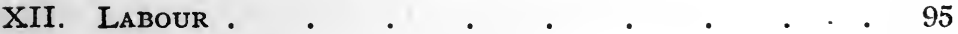

XIII. Race Transference and Colonization . . . 104

XIV. Transport and Communication-Land Transport-

River Transport-Canals-Ocean Transport-Aerial

Transport-Post, Telegraphs, and Languages . . 117

XV. The Development and Course of Trade-Barter and Early Trade-Trade with the East-Oceanic Period-The Slave Trade-North-East and NorthWest Passages-Modern Trade . . . . 138

XVI. The ORIgin and Growth of Towns . $\quad$. $\quad .157$

XVII. Trade Routes by Sea-Sail and Steam-Atlantic Routes-Eastern Routes-Pacific Routes-Panama Routes

XVIII. LANd Routes-Europe-Asia . . . . . 179

XIX. LAND Routes (continued)-Africa-Australia . . 189

XX. LAND Routes (continued)-North America-South America . • • • . . • . 197 APPENDIX-References to Books . . . . 205 INDEX . . . . . . . . . 206 



\section{INTRODUCTION}

\section{SCOPE OF ECONOMIC GEOGRAPHY}

Economic geography is that aspect of the subject which deals with the influence of the environment, inorganic and organic, on the economic activities of man. As Mr. G. G. Chisholm has pointed out, it embraces all geographical conditions affecting the production, transport and exchange of commodities. These conditions must be studied in the past as well as the present in order that their changing nature may be appreciated and future possibilities foreseen. Unless the subject is to be narrowly limited it includes that aspect of geography which deals with the settlement of lands, migrations of people, and the economic problems involved in the meeting of diverse races.

It is obvious that in a subject like geography which considers the distribution of many different kinds of phenomena, facts must be borrowed from other studies. The sciences of geology, meteorology and biology are of chief importance, but metallurgy, economics, anthropology and history give their contributions, and even physiology helps. It remains for the geographer to treat these facts geographically. In this volume many facts are recorded which are not in themselves geographical, but their geographical bearing is shown. An adequate knowledge of the tributary sciences is helpful but not essential to the geographer : it is their conclusions which he requires.

Economic geography, like other branches of the subject, must be treated scientifically : cause and effect must be studied. Thus the facts fit together and the structure of the

Scientific

Treatment

Necessary science is built. It promotes clear thinking to distinguish between the science and its application. Facts are recorded, explanations traced and tendencies indicated. The application of the principles deduced may or may not follow. The facts of the conditions of the growth of cotton, involving considerations of soil, climate, labour, transport, markets, and perhaps tariffs can be discovercd 
by an examination of existing cotton lands. This knowledge may then be applied to the extension of cotton growing areas. The facts of colonization can be gathered from a survey of past and present colonies. It remains to apply this knowledge to the settlement of new lands. The aim of the study is to discover the facts and laws of economic geography and not primarily to promote commerce or to make money. These facts are like all other knowledge, an asset in practical affairs, but their value in this respect depends on the intelligence with which they are applied.

\section{MAN AND HIS ENVIRONMENT}

Wherever man lives he has to adapt himself to his surroundings in order to get the two fundamental necessities of food and shelter. The need for clothing, which is a form of shelter, is decided by the climate. Physically an unequal match for the larger and quicker animals at whose mercy he was, primitive man had to fight these with brains or the human race would have been lost. The adaptations to his conditions of life which man exhibits are not structural but intellectual and occupational. These in their turn react on his mental activities and influence his thought. Each primitive occupation develops its own characteristics in man. There is a human nature for each and not one for all in common. The hunter's nature is to destroy, and death becomes his ideal. The shepherd conserves and so idealizes life: age and experience rather than youth and physical prowess are respected. Hence his veneration for tradition, birth and lineage. The agricultural nature is one of construction and development. It idealizes peace because war is incompatible with the fixity of agricultural life and is destructive of resources. In a similar manner the urban nature with its detachment from the soil tends to instability, new departures and a lack of attachment with the past. It is no mere coincidence that agricultural England in the main follows one line of political thought, and industrial England another, or that the Scottish highlander and lowlander from time immemorial have taken divergent points of view and seen little good in one another. It is not an accident that Australia and British Columbia take similar attitudes towards Asiatic immigration, and it was no chance that made the northern and southern states of America take opposite 
views on the question of slavery. These are but a few examples of political problems which have their roots deep in the environment and can be understood only by a study of geographical relationships.

Human society is not an abstraction that can be studied apart from the milien in which it lives and works. Any attempt to do so by ignoring the agencies which mould it tends to invalid conclusions. Man, his work and the place where he lives, are parts of a single study of much complexity. The human community is a growth of the region it occupies.

In the subtler forms of its influence the impress and influence of the environment may be overlooked. Man speaks of his con-

\section{Influence of}

Environment

quest of Nature and imagines himself entirely a free agent. His conquest of nature means that he has found in some measure how to utilize the forces of nature to his advantage and how to escape their detrimental influences. He gains a certain mastery over energy and the power to direct it to his well-being. Man is discovering nature's laws, but he cannot make himself an exception to their operation. The tropics are still the tropics for all he can do. It is still impossible to cultivate bananas in Ireland or vines in Lapland. Man discovers the conditions of life required by banana and vine, but his cultivation of them is still confined to those regions which have the necessary climatic conditions.

Railway routes in a mountainous district follow more or less the lines of former traffic by valley and pass although they tunnel under the summits. Africa still stands athwart the ocean route from Europe to the East and the narrow isthmus of Suez still focuses traffic: the Suez Canal is merely an improvement on the old overland route. In some ways mankind is more dependent on his environment than of old. Coal enters much more into the economy of civilized man year by year. Dependence on imported food gives the inhabitants of Britain less freedom of movement, than use of local supplies. This was impressed on all during the period of severest rationing in war.

At most it may be said that man, among the more favoured classes of civilized communities, has escaped the servitude of Nature. Among more primitive people, whether in the African forest or in the fields and cities of western Europe, man is still in the grip of his environment and responds closely to its influence. 
It must be borne in mind that material environment does not embrace all the moulding influences. Less obvious and more

\section{Influence of}

Traditions subtle are the traditions and social heritage of a people. Escape from one material environment to another is possible but emancipation from the traditions of childhood and the social code of schooldays is singularly difficult. These intangible influences, for better or for worse, are at the root of education in its widest sense. In the formative years of childhood and adolescence the imprint of the mental atmosphere makes a deep and lasting mark. The problems of human migration are complicated by the problems of the migration of tradition, social codes and culture as a whole.

No doubt to a great extent the mental equipment of a people, as expressed in their beliefs, traditions, and prejudices, is the outcome of the material environment of the past. It is the social heritage of the nation. That is why the social code is so full of anachronisms. Overloaded with the influences of the past it has never caught up on the existing conditions of life: It binds the community to a bygone era, and the results of the physical and mental environment of to-day will be absorbed into the social heritage only when the age is past. If man has to struggle in the grip of physical nature he can at least discover the road of least resistance and pursue it to his advantage. His social environment is a more domineering master. A mountain range can be crossed by a path, a narrow strait can be tunnelled, and an arid land can perhaps be irrigated, but a breach of the social code, an offence against the traditions of a people or an attack on the fabric of society brings swift retribution in its train. It is beyond the province of the geographer to analyze and estimate the force of the social environment but its existence and importance are factors which he must bear in mind.

There is surely another side to all this : "That man, like any other vigorous organism, is a forceful agent, full of effort and endeavour, often with a bow slightly bent." That is true, but it applies rather to the individual than to society as a whole. A community of human beings lacks the initiative of the few mentally active individuals it includes. Mankind in bulk expresses the type and not the exception. The mean level in mental freedom and intellectual force of any community lags far behind the few. 
The geographer has to deal with groups and not individuals: to him it is the type or mean level of the community which counts. A forceful personality is a rebel against his social environment which often succeeds in crushing him : he becomes an organizer and leader only in measure as he escapes from one social environment to another in which his exceptional mental activity finds favourable surroundings.

At the same time the reaction of man on his environment must not be overlooked. In the reclamation of waste land, the irrigation of deserts or the sane planning of towns are exam-

Function of

Geography ples of the application of geographical control to human well-being and advantage. Geography can find an ampler justification than academic research when it becomes formative and constructive. The utilitarian side of economic geography has been too much emphasized solely as an aspect of commercialism. The function of geography is to explain and interpret. Later comes the application of its principles to the betterment of mankind, not merely to the furtherance of moneymaking. If geography teaches anything it is the insanity of the reckless exploitation of the world's resources, organic and inorganic.

It is a prevalent habit to attribute to races, or supposed races, traits and characteristics which in all probability are not inherent but are merely expressions of the imprint of the Racial
Characteristics environment, and in that respect are not peculiar to one race rather than another. The geographer must go deeper and seek the explanation of so-called racial characteristics.

Human races are biologically merely varieties of one species. There is a tendency to exaggerate the differences between them. It is not certain to what extent racial characteristics are germinal variations in the species or modifications which occur in response to environment. ${ }^{1}$ In any case there is little evidence that racial differences are of much importance as adaptations to environment nowadays, except as regards acclimatization. Under these circumstances race has comparatively little geographical significance. On

1 For a further consideration of these problems reference should be made to some work on biology, e.g., Heredity, by Prof. J. Arthur Thomson, London, 1919, or Evolution, by Prof. P. Geddes and J. A. Thomson, in the Home University Library. 
the other hand there is the abundant proof of environment having a moulding influence on man quite irrespective of race. Sections of the same race differ widely in mental characteristics under different conditions of life. Moreover, in a continent like Europe intermingling of races has gone on to such an extent that the task of disentangling them is most perplexing and controversial. It is doubtful if any sure ground can be reached in an attempt to correlate the racial elements of Europe with the mental attributes of its various peoples.

At the same time it is idle to deny that certain races are mentally higher than others, and the differences appear to be inherent. No change of environment suggests that the negro can be raised to the level of the white man or that the Australian aborigine can develop intellectual powers. Variations in these human stocks, to cite only two, do not appear to be in the direction of mental prowess.

There is much need to revise the long accepted assertion that nationality is an expression of race. In the United States the diverse racial elements of Europe in one or at

Nationality and Race most two generations lose their old and assume a new nationality. Canada, Australia, and other self-governing dominions each evolve a nationality distinct from those of their component races. The various states of Central America have strong national feelings despite the races common to all. Slight racial differences cannot explain the diversity in nationality of Scotland and Ireland. And the wide difference in outlook and nationality between north Germany, Holland, and eastern England is far greater than can be explained by the small racial distinctions between those countries. A nation is born of the land in which it lives.

Language less than race is a criterion of nationality. There is no attribute a people gain or lose quicker than language. Linguistic frontiers are unstable.

Recent events have brought into prominence the whole question of nationality. Various writers have tried to find its basis. Not only race and language but history, tradition, and religion have been suggested, and no doubt all are contributory factors. Dr. M. Newbigin has probably got nearest to the truth in admitting all these factors but laying stress on a community of economic interests. This is perhaps at the root of nationality, and if so it suggests that 
nationality is not an immutable quality but may change from age to age. Economic interests may even overrule tradition, which is the strongest of all other fibres in the fabric of nationality.

The geographer sees in the diversity of communities in the modern world a reflection of the diversity of physical and other conditions which it is his task to recognize and

Selfdetermination study. He realizes that any attempt to impress uniformity on diverse communities is doomed to failure because it ignores the fact that physical environment cannot be changed. Geography emphasizes the individuality of every community. This individuality has a need for expansion, which is admitted when the principle of self-determination is recognized. The difficulty in the application of this principle is the common human difficulty in knowing where to draw the line. Nationality is but one degree in regional consciousness. Despised parochialism, county patriotism, national sentiment, and pride in imperial heritage are various steps. While the smaller unities are very real the larger ones become somewhat abstract, and the larger the unities the looser the bonds. Powerful motives, whether in war or in commerce, may bind smaller into larger unities temporarily and strengthen loose bonds for a time, but under changed conditions the ties dissolve. An empire may hold together when the daughter nations are linked solely by ties of sentiment to the motherland, but is more likely to split asunder if the shackles of a central bureaucracy try to bind it. The nations of an empire grow more diverse in each generation and resist attempts to order the lines on which their growth is to proceed.

A common interest bound together most of the nations of the world in the European war, but the League of Nations which seemed so real in those days, lacks vitality in time of peace. Political and commercial interests divide and subdivide communities when no common purpose unites them. The immediate interests of nation, province, region, and city then find expression. Geography teaches that regional consciousness in all its degrees is a function of mankind, and that internationalization, in so far as it attempts to stifle regional expression, is a fallacy. 



\title{
THE PRINCIPLES OF ECONOMIC GEOGRAPHY
}

\author{
CHAPTER I \\ THE PHYSICAL ENVIRONMENT
}

ROCKS AND SOILS

DRY land covers only about one-fourth of the total surface of the globe; two-thirds of the land lie in the northern hemisphere. Australia and Antarctica are the only two continUnequal ents which are entirely within the southern
Distribution of Land

hemisphere. This unequal distribution of land on the surface of the globe determined that human development should make most progress north of the equator. Furthermore, the land masses in the northern hemisphere are more or less close to one another while those in the southern hemisphere are separated by wide stretches of ocean. Africa, South America, and Australia are each in closer relations with the lands of the northern hemisphere than with one another.

In every land mass, for which continent and island are but relative terms, certain types of land forms can be recognized. Mountain, valley, plain, and plateau are terms

Types of which express to everyone familiar images. These
Land Forms land forms are continually changing under the influence of running water, wind, sunshine, atmospheric action, plant life, and sometimes volcanic action. There is no permanence in surface features. Rivers are cutting valleys out of the plains and plateaux, leaving blocks standing as mountains. Weathering influences are changing the outlines of upland and lowlands. Plains are growing seaward as river-swept waste is deposited in shallow water. The waves of the sea are cutting away and destroying the cliffs. Furthermore, the land is seldom stable but is either slowly sinking or rising. These changes, except in the case of volcanic and earthquake occurrence, are generally very gradual, but some are rapid enough to be appreciable within a few years' time. 
The many different kinds of rock which form the surface features of the globe can be grouped into certain divisions according to their origin. Igneous rocks are those which have Kinds of Rocks solidified from a molten state; they are unstratified and crystalline in structure. Some, like granite, have solidified deep below the surface under enormous pressure, and their exposure to-day is due to weathering influences acting through long ages having removed the superincumbent rocks. Others, like lava, have generally been poured on the surface in a molten state, and have solidified in contact with the air. Sedimentary rocks are composed of water-, ice-, and wird-swept waste which originally accumulated in the sea or on lake floors and has been since elevated to form dry land. These rocks are stratified, and as a rule fossiliferous. Limestone, sandstone, shale, coal and conglomerate are examples. Metamorphic rocks such as gneiss and schist, are sedimentary in origin, but by the agency of great pressure and high temperatures have been partly stratified and rendered crystalline.

The geologist recognizes the relative ages of rocks and classifies them according to periods of geological time without attempting to suggest a term of years for each period. The

Relative Ages of Rocks

main divisions in the geological record are Archaean, Primary or Palaeozoic, Secondary or Mesozoic, Tertiary or Cainozoic, and Quaternary, the last including the present period. While the consideration of the age of rocks is mainly one for the geologist these terms so frequently occur that the geographer must be conversant with them.

The different origins and ages of rocks enter into any study of scenic features and the evolution of surface relief. To the economic geographer their importance is rather in the soils Geographical to which they give origin. Soil is formed of Rocks

weathered and decomposed rock with or without the addition of matter of plant and animal origin. Soils may either be of local origin or have been transplanted from a distance by the agency of running water, glaciers or wind. Variations in the composition, texture and depth of the soil affect the crop that can be grown and more particularly its yield. The most fertile soils are as a rule those due to the decomposition of lava, or alluvial and wind-swept soils. Alluvial soils may be of river or 
glacial origin. They owe their fertility largely to their fine state of division and the diversity of their constituents. They are one of the factors which have always encouraged populations to settle in river valleys. The chief wind-swept soil is loess or black soil, noted for its fertility, in China, southern Russia, and some of the central plains of North America.

While the study of surface feature is of great importance in geography as forming the basis of the subject, it belongs, properly speaking, to the more general side of geography and cannot be treated in any detail in a book devoted only to the economic aspects.

\section{CLIMATE}

Climate as opposed to weather means the average state of atmospheric conditions. Weather refers to a single occurrence. The climate of a locality leads to important economic results but exceptional weather conditions may have marked effect. In a study of climate certain climatic elements can be distinguished, namely, temperature, pressure, winds, and humidity.

Generally speaking, temperature decreases from the equator polewards, the regions with more insolation having a higher temperature than those with less. But two considerations

Temperature profoundly modify this ideal simplicity. First, the inclination of the earth's axis to the plane of its orbit which results in the alternation of summer and winter in all except equatorial regions: secondly, the unequal distribution of land and water. Land is heatcd more rapidly than water by the sun's rays, and on the other hand loses its heat more rapidly when the insolation is withdrawn. The effect of this is that oceans and seas tend to equalize temperatures in their vicinity and prevent the great ranges of temperature which temperate continental interiors experience.

The atmosphere when free from impurities is heated by radiation from the earth's surface. The lowest strata are the warmest, and temperature falls an average of about $1^{\circ} \mathrm{F}$. for every $300 \mathrm{ft}$. of elevation. High elevations experience low temperatures. Altitude counteracts the influence of latitude as far as temperature is concerned. 
Ocean currents exercise a considerable influence on temperature. The influence is mainly felt in association with the prevailing winds on which also the currents are largely dependent.

Effect of Currents on Temperature The contrast in climate between east and west coastal lands in temperate regions is very marked. Warm currents wash the western coasts and the prevailing winds are from the south or west. On the other hand, eastern coasts are bathed by cold currents and have a high proportion of northerly winds. The result is seen in the ice-free harbours of the British Isles and Norway, or British Columbia, and the frozen harbours of Labrador or north-eastern Asia.

A heated land or water surface results in ascending currents of heated air and the formation of a low pressure system. A cooled surface conversely leads to a high pressure system.

High and Low Pressure Areas

Air currents flow inwards, deflected by the earth's rotation, to fill up a low pressure area : they flow outwards from a high pressure area to lower pressures surrounding. The strength of the winds depends on the contrasts between the two pressures or, in other words, on the pressure gradient.

Certain high and low pressure areas are more or less permanent in position and give rise to regular winds.

The heating of the air in equatorial regions results in a permanent belt of low pressure and calms known as the doldrums, towards which winds normally blow through tropical regions. These equator-seeking winds are deflected by the earth's rotation and blow as the north-east and south-east trade winds. Their presence is marked only over the ocean as a rule.

At the poles the cooling of the atmosphere causes permanent high pressure and out-blowing north-easterly and south-easterly winds. These are in too high latitudes to enter much into consideration of trading vessels except in rounding Cape Horn from east to west.

Beyond the polar easterlies a belt of low pressure girdles the earth owing to the higher temperatures. This belt is continuous and permanent in the southern hemisphere where little or no land breaks the sweep of the ocean. Between lat. $60^{\circ} \mathrm{S}$. and $40^{\circ} \mathrm{S}$. blow the brave west winds in the roaring forties (and fifties). In the northern hemisphere the alternation of land masses with oceans interrupts the continuity of this low pressure belt. It is 
found in the North Atlantic and North Pacific well marked in winter but less noticeable in summer owing to the low pressure over heated North America and Asia. The westerly winds over the North Pacific and North Atlantic oceans are normally winds pouring spirally into these two oceanic low-pressure systems.

Seasonal low and high pressure systems over the continents are dependent on seasonal changes of temperature and result in air currents flowing respectively into and out from Monsoons the continent. Under some circumstances this reversal of winds is very marked and characterizes the seasons. In these cases the winds are known as monsoons. They are most prominent and have been longest known in India and south-eastern Asia, but monsoons occur in various other parts of the world, notably West Africa and northern Australia. The land and sea breezes commonly experienced on our coasts in summer months are monsoons in miniature.

All precipitation, whether in the form of rain or snow, is eventually derived from the sea. Under most circumstances lands near the sea experience more precipitation than far Rainfall interiors, but this is not invariably the rule. Some coastal lands are dry owing to the normal winds being off shore. Such is the case with those tropical lands from which the trade winds blow. Those lands, on the western side of the continents, are largely deserts. A great deal of tropical rain falls irrespective of winds, and is caused by the condensation of moisture in ascending air currents. But as a general rule precipitation reaches the land by the vehicle of winds, the moisture held in suspension being condensed for one reason or another in contact with the land. High land causes condensation of moisture partly because it directly cools the air currents and partly because it forces the air currents to ascend, expand, and so cool. Mountains lying athwart prevailing onshore winds thus receive a heavy rainfall which is shared to some extent by plains on their seaward side. Land to the leeward of such mountains receives less precipitation : if the mountains are high enough it receives practically none. The close relationship between rainfall and elevation is well shown in a rainfall map of the British Isles which roughly corresponds with the orographical map.

Lands which receive most rainfall are those which lie all the year 
round in the track of onshore winds, provided the elevation of the land is sufficient to cause condensation of moisture. Lands at a distance from the sea are generally much drier but great elevations may in a sense compensate for distance and result in heavy rainfall.

The seasonal distribution of rainfall is of great importance to the geographer. The belts of prevalent winds noted above swing north and south with the apparent " movement"

Importance of of the sun or, more strictly speaking, with the Seasonal Distribution revolution of the earth round the sun. Moreover, the reversal of pressure over the continents, particularly the temperate ones, results, as described above, in reversal of winds. In temperate regions oceanic borderlands as a rule receive most of their precipitation in winter, but summer is not dry. Far interiors receive most of their little precipitation in summer. Towards the tropics there is a zone which is outside the westerly regime in summer. This is the region characterized as having a Mediterranean climate, the name being derived from the area where the climate is best developed and most studied. Mediterranean rainfall is in the winter : the summer winds of the ocean blow seawards and cause a rainless season.

In the monsoon lands rainfall is heavy in the season of onshore winds, that is, the season during which the sun is overhead in the hemisphere in question. The reverse season is normally dry.

Equatorial regions have normally two wet seasons and two dry seasons during the year. The period and duration of these seasons varies with distance from the equator. In many cases the two wet seasons merge into one, or they may be alternate with a less wet season and a long dry season.

The annual amount of precipitation varies very greatly. Its amount in relation to vegetation and human life must always be

Variation of Rainfall considered in relation to the prevailing temperature of the rainy season. Less than $10 \mathrm{in}$. a year generally results in arid or desert conditions. The annual fall may be spread over every week in the year, as in the British Isles, and not amount to over $30 \mathrm{in.,}$ or it may fall exclusively in a few months and amount, as in the case of the eastern Himalayas, to over 400 in. a year.

The prevalence of cloud is an important geographical consideration in its effect on vegetation. Over temperate ocean and seas 
and on bordering lands cloud is very common. In seas where cold and warm currents meet, the prevalence of fog is a continual menace to shipping. The fogs on the Newfoundland banks are a good example of this phenomenon.

Owing to the climatic contrasts obtaining near the sea and at a distance from it, it is convenient to distinguish two types of climate, maritime and continental. The first is characTypes of teristic of islands and coastal lands: the second
climate of continental interiors. These contrasts more or less hold in all climates. A third type of climate characterized by altitude may also be distinguished.

Numerous attempts have been made to classify climates. For these reference must be made to works on general geography.

The rough division into equatorial, tropical,

Classiffeation

of Climates temperate, and polar is useful, but hard and fast boundaries cannot be laid down. It must be remembered that transition climates link adjoining zones.

Equatorial climates are characterized by high temperatures throughout the year with no cool season and heavy rainfall in nearly all months. The mean annual temperature is over $70^{\circ} \mathrm{F}$.: the daily range is greater than the annual range which seldom exceeds $5^{\circ} \mathrm{F}$. Drought is unknown, the rainfall averaging about $100 \mathrm{in}$. a year.

Tropical climates have a mean annual temperature of not less than $68^{\circ} \mathrm{F}$., with an annual range as a rule not much over $10^{\circ} \mathrm{F}$. As a result there is no cold season but a period that is comparatively cool. Rainfall is seasonal and very variable in amount. When it is under 10 in. a year hot deserts like the Sahara or the Atacama desert occur. The term subtropical is often used for the transition climate known as the Mediterranean.

Temperate climates show most diversity. The contrasts between oceanic and continental conditions are marked. Temperate climates are characterized by considerable range in temperature between summer and winter. Range of temperature rather than range of precipitation marks the seasons. The warmest month has a mean temperature not below $50^{\circ}$, and the coldest month often has a mean below $32^{\circ} \mathrm{F}$. Precipitation is not heavy as a rule and may occur at all seasons, or principally in summer.

Polar regions have a continuously low temperature except for 
a very brief summer. The mean of the warmest month is under $50^{\circ} \mathrm{F}$., and that of the long winter well below $32^{\circ}$. In Antarctic regions the annual summer mean is below $32^{\circ}$. Precipitation is about 10 in. a year. In this climate the cold deserts of the world occur.

In these zones of climate exceptions occur in lands at high altitudes. These form regions of temperate or even polar climate in the midst of tropical climate, or of polar climate in temperate lands. 


\section{CHAPTER II}

\section{THE INFLUENCE OF CLIMATE}

No factor of his environment exercises a wider influence on man than climate. Its influence is largely indirect in its relation to vegetation and crops, but ultimately it is the dominant control of human activity. Perhaps it is needless to dwell on the fact that moisture and heat, two climatic factors, are essential to human life, for in this respect human life shares the requirements of the whole organic world : moreover, there are few places on the surface of the globe where the requisite temperate and moisture do not occur. Climate, however, rules some regions practically out of account as possible homes of man. The ice deserts and snow caps of the world are of this nature : human life can exist but only with considerable difficulty and the transport of all necessities except water.

Climate is a factor of the environment which makes itself felt through the primitive wants of food and shelter at every step.

It is a condition which cannot be modified. Man Man's can cut through an isthmus or bridge a river, but Dependence on he cannot affect the rainfall or change the winds.
Climate The best he can do is to remedy the deficiency of rainfall in a desert by borrowing surplus rainfall from elsewhere with which to irrigate the ground. But this can be done only on a small scale: the great deserts remain deserts and will do so unless man discovers new means of harnessing solar energy. In man's attempts to escape the thraldom of climatic influences lie his adaptations of food, shelter, and clothes. The extent of these adaptations is a measure of his success and progress, but at the same time they make his dependence on the climatic factor.

Climate is also the controlling factor in trade, except the trade in minerals, because climate localizes the growth of plant and animal products, and to a great extent decides the nature of the manufactured goods required in exchange. 
In its broad effects the operations of climatic control are so obvious as often to be overlooked. The birth of civilizations in warm, temperate and subtropical regions, and

Operations of Climatic Control their gradual migration to cool temperate regions with their rapid growth under these conditions, are indirectly due to the influence of climate. So also is the backwardness of civilization in the damp, tropical regions and the polar lands. Both have a repressive influence on the progress of man.

Again, the habitability of high latitudes on the west side of continents and the comparative inhospitality of the east sides in the same latitudes are the result of differences in climate. One has only to compare Britain and Norway with Labrador, or British Columbia with Kamchatka to realize this distinction. Direct climatic influence is shown in the effect of freezing of rivers and seas. The isolation of Siberia is largely due to the fact that its magnificent natural waterways are frozen for about seven months every year, and when flowing freely in summer lead to a sea which is intermittently blocked with ice. Russia, Finland, and to some extent Sweden, suffer from the freezing of the Baltic and the closing of most of their seaports in winter. This circumstance was largely responsible for trend of Russia's policy in the Black Sea as illustrated in her repeated attempts to control Constantinople and so obtain a winter route to the open sea. It led also to the construction of the Murman railway in the north with its outlet on a sea kept open in winter by a branch of the warm Atlantic drift. For the same reason the revived state of Finland aims at a seaport on Pechenga fjord.

Summer and winter in temperate regions, and for that matter in polar regions, even more so, are alternations between active and dormant periods in plant growth : they are respectively seasons of growth and sleep. This alternation is reflected in the type of agriculture pursued, and not only makes summer a period of great activity in the fields and a time when food must be grown and stored to tide over the winter, but also ensures a long winter of restrained activity and enforced leisure. Man has not wholly lost his hibernating habit in northern regions. The long winter evenings spent indoors have had much to do with the high standard of education among such people as the Scots, Norwegians, and 
Icelanders, and this in spite of primitive conditions of life and a hard struggle against Nature.

In another chapter (Chapter XIII) reference is made to the problems of human migration in relation to climate, and it is shown that similar climates encourage people to spread over $\underset{\text { Migration }}{\text { Human }}$ wide areas. They lead to great similarity in mode of living, even among widely divergent races. The climate of the tundra, and its correlated vegetation, has effected this in the case of the Lapps of Europe, the various tribes of northern Siberia from the Samoyedes to the Chukchecs, the Eskimo of Bering Strait, and even the Indians of Alaska. Marked climatic barriers stem the tide of migration as effectively as mountains or seas.

In a minor way climate largely decides the movements of invalids and idlers. Summer means a migration from London to cooler Scotland or Norway : winter is the time to scurry southward beyond our harsh climate into the sunshine of the Mediterranean which is only left when the sun becomes too strong and spring at home beckons the wanderers northward. Less favoured classes can migrate to the country only for a few weeks in summer, and it is noticeable how this migration is delayed until comparatively late in the season owing largely to the fickle spring, but no doubt in some measure because of a lothness to break away from the gregarious life of the towns.

A more vital migration dictated by climate is that of the European administrators in the tropics from the plains to the hill stations during the hot, wet season. Thus the importance of such places as Simla or Coonoor in India, Maymyo in Burma, or Nuwara Eliya in Ceylon. All the capital cities of tropical America, with the exception of Rio de Janeiro are at considerable clevations; and Rio's existence is incomplete without Petropolis on the heights of the plateau near by.

Climate influences the type of architecture, the plan of buildings, and the material employed in construction. Stone, concrete, or

Effect of

Climate on

Architeeture, ete. fire-baked bricks and sloping roofs covered with slate or thatch, are a necessary protection against the prevalent low temperature and heavy rainfall of the British Isles. In hot countries with little rain, such as Mediterranean lands, the flat roof serves as a vantage 
point and a living place more airy than enclosed rooms. The verandah of tropical houses, like the courtyard of Mediterranean architecture, gives the dwellers open air without direct sunshine. Perhaps on the same principle hot countries have narrow streets in their towns : the wide street is more suited to northern towns in latitudes where the sun is low. At the same time it must not be forgotten that narrow streets were broad enough when there was less and slower traffic. The use of sunblinds and punkas is dictated by latitude and climate. Double-walled timber houses with intervening air-spaces are a protection against the cold in the far northern winter, just as latticed blinds are a characteristic of very sunny countries. The squat or rounded structures of lighthouses and signal stations on the coasts are designed to resist wind pressure. In like manner the frail houses of tropical peoples give all the shelter required in climates where the temperature is always high enough for living out of doors. The snow hut of the Eskimo expresses a climatic adaptation in building material. The construction of a wireless station in Spitzbergen some years ago was rendered difficult by the fact that not more than ten weeks building season could be assured without the risk of frost which would prevent the setting of the cement.

The great open fires of British houses are so necessary in our uncertain, normally inclement and dismal weather that the hearth has become one of the symbols of home. In lands with a severer but less gloomy winter, such as central Europe, Russia, and temperate North America, the closed stove with its greater heating power replaces the cheerful open grate.

The climatic factors also have considerable influence on trade routes and means of transport. Snow may block passes and impede railways and heavy rainfall may undermine

Influence on embankments. Desert railways are always liable to be interrupted by drifting sand dunes. In the days of sailing ships prevailing winds largely determined trade routes, and ports on the open ocean were more favourably situated for vessels than river ports or ports on narrow seas. By the Cape of Good Hope outward and by Cape Horn homeward is the normal course for a sailing vessel to Australia and New Zealand. Neither the Suez nor the Panama Canal are of use to sailing vessels which would not only require towage through the canal but be obliged 
to waste time in navigating the regions of normally light winds in which both canals lie. The effect of sea-ice on trade routes has already been noted.

The use of the Plimsoll mark on vessels' sides to indicate the load line denotes a recognition of the importance of climatic influences in commerce. Fresh water, Indian summer, Summer, Winter, and Winter (North Atlantic) indicate the various depths to which the ship may be loaded under different conditions.

Land routes are much affected by snowfall. In countries where the fall is heavy, or at any rate lies long on the ground, sledges replace wheeled vehicles in winter. In northern Russia and Siberia - there is a season called rasputitsa, when no vehicles are of much use. This is in springtime when the melting snows make the ground sodden and impassable by wheel or runner.

Climatic factors frequently influence the localization of manufactures (Chapter X). An instance often cited is the greater suitability of Lancashire than Yorkshire for

Climate and

Manufactures cotton spinning. The more uniformly humid climate on the west of the Pennines is necessary for vegetable fibres free from fat, while the animal fibres charged with grease resist hygroscopic changes and so can be spun equally well on the drier east. A more striking instance of climatic control of mdustry is to be found in the new cinema film industry. In order to get the best effects in photography a clear climate with abundant sunshine and few cloudy days are required. California is said to be the best centre for this industry, and next come Italy and southern France. Climatic influences do not favour the production of films in the British Isles.

The division of Great Britain for coal rationing in 1917 signified a clumsy failure to realize the real climatic divisions of the country.

It is more difficult to trace the influence of the climatic factor on the mental life of people, and almost impossible to estimate the value of the various climatic elements, temperaEffect of ture, atmospheric pressure, winds and precipita-
climate on tion. Yet there is no denying the energizing effect of cool climates and the enervating effect of warm ones, particularly if moist. A cold climate has been rightly said to put a steadying hand on human heart and brain. The result is obvious if the means by which it is achieved are not 
clear : climate, not racial, difference is responsible since the same traits are found in widely divergent human stocks. There is a marked contrast betwcen the cool northern and warm southern states of the United States in the energy and vitality of the Americans as expressed in the numbers of lcaders of men and great thinkers they produce. Perhaps this same contrast finds expression in our own country in the tendency for light reading in summer as opposed to serious reading in winter. The "seaside novel" is notoriously trashy.

The depressing influence of gloomy weather and the exhilarating effect of dry sunny weather, especially if cold, are familiar to all. The climate of the British Isles is suitable for outdoor exercise at all seasons of the year : in fact the damp raw climate of more than half the year demands a certain amount of vigorous excrcise for the maintenance of health. This may explain the excessive addiction to sport of the British people, even to the neglect of education in youth and work in adult life. The lazy casygoing ways of scuthern Europeans and South Americans generally are probably also a response to climatic conditions. Eastern habits of procrastination and leisurely unconcern suit the climate of India far better than European business and American hustle, and after a little experience are generally adopted by whites.

National temperament is no doubt far more an expression of climate and correlated activity than a function of race. Proof may be difficult to obtain but there is every likelihood that the stubborn dogged perseverance, and the imaginative nature, strongly tinged with melancholy, which are characteristic traits of the Scottish highlander, are the outcome of the gloom and mist and wild climate in which he lives. The Irish Celt in more genial climatic circumstances is far more buoyant and mirthful and less tenacious of purpose. The sombre colour in dress beloved by most classes in the British Isles-it might also be said the fear of colour-is likely enough caused by the high humidity of the atmosphere and the consequent subdued tones in landscape. On the other hand the clear-cut features and the vivid hues of the dry Mediterranean atmosphere find their reflection in the Italians and Sicilians' love of bright colours. The Italian ice-cream shop is the one note of brightness in the uniform dullness of a street of any of our industrial towns. 
The American geographer, E. Huntington, has collectcd a mass of data bearing on the effect of climatic influences on human

Climate and Human Activity

activity. His conclusions are of interest, and if confirmed by further observations may have important bearings on economic development. He claims that records of several thousand workmen and students in the eastern United States and in Denmark show that man is physically most active when the mean temperature is $60^{\circ}$ to $65^{\circ} \mathrm{F}$., and mentally most active when the outdoor temperature is about $38^{\circ} \mathrm{F}$. with light frost at night. But an equable unchanging - temperature decreases bodily activity and the same is true of sudden changes of temperature. A high relative humidity, or in other words moist air, induces the best work, while storms are stimulating. Huntington found seasonal variations in activity most marked, and he believes that the best results in factory work would be obtained by slowing down machinery in winter, increasing its speed in spring, slightly decreasing it again in summer, and running it fastest of all in autumn. His researches tend to prove the ill effects of a monotonous climate: in which case our own climate should be the most conducive to a high development of energy.

The degree to which the physical characteristics of various races can be associated with climatic influences is very doubtful. In all probability there is little connection. The black races are not necessarily associated with regions of intense insolation, and conversely all tropical races are not dark.

Yet the close parallel of the American type of the plains, long, loose-limbed and hatchet-faced, with the North American Indian has not been explained, and certainly cannot be attributed to a strong admixture of Indian blood. A distinctive Australian type, which is by no means identical with the New Zealand type, is also evolving in the southern continent. 


\section{CHAPTER III}

\section{THE INFLUENCE OF VEGETATION}

Almost the entire land surface of the globe, except those regions covered with ice or devoid of water, has some kind of vegetation. Plant growth varies in luxuriance from the dense equatorial forest interwoven with hanging plants and creepers into an almost solid mass of vegetation, to the lichen covered rocks of high mountain peaks or the scattered patches of moss growth in polar lands. In our own country we need only contrast the rich meadow lands of Devon or Cheshire with the moorlands of the Pennines or the Scottish Highlands, or the marshy fenlands around the Wash with the short scrubby vegetation of the sand dunes of Hayling Island or the coast of Aberdeenshire. Without being concerned with the actual kinds or species of plants in each locality we notice a difference in the type of plant growth. It is in that sense that the term vegetation is used in contrast to flora. The forests of northern Siberia and Norway are composed of different species of coniferous trees, but they show the same type of vegetation.

Differences in vegetation are of great importance to the geographer since no aspect of his environment is in closer relation to man, or has more control over his occupations and mode

Distribution of Vegetation factors which control the distribution of vegetation. Heat, rainfall, snowfall, light, and wind are the main factors to which plant growth responds : soil has a secondary but mainly local influence. It is owing to variations in the amount and seasonal distribution of the climatic factors that different kinds of vegetation occur, apart entirely from the component plant species of each vegetation.

Plants derive their nutriment from the air, generally by way of their leaves, and from the soil by means of water which their root hairs can absorb. Water and air are thus essential to all plant growth. Light is also essential since it is only by the presence of light that the green matter of the leaves can turn the raw materials absorbed by leaves and roots into the food on which the living substance grows. Different plants require varying conditions of 
heat, light, and water, and plants being plastic and adaptable have developed various forms of growth to meet all conditions of environment.

Excess of heat or cold is not in itself hostile to plant growth. In hot deserts plants thrive at temperatures of $120^{\circ} \mathrm{F}$. or more, while Antarctic mosses subjected to temperaHeat and Cold tures of $-90^{\circ} \mathrm{F}$. do not perish. But in warmer climates plants as a rule grow more luxuriantly with greater spread of foliage than in cooler climates. Many plants while indifferent to low temperature during their resting season, require relatively high temperature during their season of growth, and in particular for the ripening of their seeds and fruits. This consideration is of much importance in determining the profitable growth of many cereal crops. Dry winds as a rule are hostile to most forms of plant growth because they cause rapid transpiration, or loss of water through the leaves. Plants living in regions of hot dry winds, or of hot dry atmosphere generally, develop various protective measures as down, wax, or resin on the leaf surfaces to prevent excessive transpiration. In some cases the leaves are much reduced in size and number ; in others the leaves disappear and the stems take on their functions. Many desert or subdesertic plants like cacti and prickly pears, have developed fleshy leaves or stems in which water is stored.

If strong dry winds take more moisture from the plant than the root hairs can supply, the plant perishes. This is the case when the soil is frozen in winter, and it is this combination of circumstances that determines the polar limit of trees. An excess of icy cold water in the ground is harmful, for water at that temperature cannot be freely absorbed by root hairs. Thus the Arctic tundras, though swampy in summer, have many drought-loving plants.

Light is a very important factor. The continuous summer daylight of high latitudes induces quicker growth than in lower latitudes. Thus cereals can be grown far north Light in spite of the short summer. Without strong light in our latitude where sunshine is usually weak, plants cannot flourish : at best they grow long and weak with little tendency to flower and seed. This tendency is taken advantage of in plants like rhubarb or celery, which are grown for their leaves and leaf stalks.

2-(1909) 
The importance of insects and birds in fertilizing flowers and aiding in the production of seed, the destructive action of other Insects and birds and insects, and the various other relations Birds between animals and plant growth can only be mentioned in passing.

Soil is essential to plants both as a holdfast and for the derivation of nourishment. Soils vary much in their composition and fertility, and also in their resistance to the percolation of

Soil water. A coarse or sandy soil allows water to drain away quickly. The soil in limestone districts dries quicker as the water soaks into the rock. Clayey soils, such as loams and marls, being more retentive of water, are generally more fertile. But soils and subsoils which are practically impervious cause swamps with their characteristic vegetation. The most fertile soils as a rule are those composed of fine-grained riverswept waste. Such alluvial soils owe their fertility to their fine division, varied composition, and the presence of a greater or less amount of organic matter.

Broadly speaking, two kinds of vegetation can be recognized, woodland and grassland: the absence of both is termed desert.

Woodland varies in nature from the rich tropical

Kinds of

Vegetation

forests to the far northern pine woods, and grassland may show every grade from luxuriant meadow land to semi-barren steppes. Trees have widely ramifying roots and a great spread of leaves. This enables them to take water from a wide area and to transpire it freely. Moreover, the depth of their roots makes them independent of the surface layer and enables them to rely on the subsoil. Grasses, on the other hand, being shallow rooted, can draw their moisture only from the surface layers of the soil. Their low growth and limited leaf surface gives them an advantage in minimizing transpiration.

Conditions favourable to woodland are abundant rainfall, either throughout the year or in any season, and a lack of dry winds which cause excessive loss of water. Grassland requires moisture spread throughout the season of growth, even if small in amount. On the other hand it is indifferent to dry winds in winter and little influenced by them in summer.

The effect of an unusually hot and dry period in summer illustrates well the distinctive wants of woodland and grassland. On 
such an occasion the leaves of the trees droop by day but recover by night when transpiration is checked. Meanwhile the grass does not appear to suffer but if the drought continues long dries up and dies. The trees survive none the worse for the experience.

Woodland conditions occurring in the tropics cause a dense forest growth in which the trees are of many kinds, but, having

Woodland

Conditions abundant moisture and no inclement season to face, are nearly all characterized by wide soft leaves. In temperate regions woodlands either lose all their leaves in winter, like the oak, elm, etc., or they develop a needle-like leaf which presents a minimum surface to winds : these are coniferous trees such as the pine, fir, and spruce.

Under drier conditions grassland as a rule develops if the seasonal distribution of rainfall is suitable. Rich grassland as a natural form of vegetation is rare, but poor grassland, Grassland Conditions including various kinds of steppe and scrubland, is common.

While the conditions that lead to tropical forests are too overwhelmingly in favour of tree growth to allow the forest to be permanently destroyed, those that cause temperate woodland are near the climatic balance between trees and grass. The softleaved temperate forests can be and are being replaced throughout the northern hemisphere by grass and turned into arable land. Temperate forests once destroyed can only with difficulty be restored, for their growth is slow.

It has already been pointed out how the forests of the world were originally the haunts of hunting communities, and the steppe lands the home of shepherds. This is still to a great extent the case. But the growth of population and increasing skill in agriculture, together with the demands of trade, have made new demands on the resources of sparsely peopled lands. The hunter is not allowed to retain his forest if the peasant can put the land to better use for agriculture or requires the timber for building. The nomadic herdsman of the desert has to yield his land to the farmer who has found means of turning it to account with the help of irrigation.

The forests of the world are now of importance mainly for their yield of timber. It is growing demand for timber that is year by year reducing the forest areas of the cool temperate regions and compelling serious consideration of their wasteful exploitation. 
Tropical forests are composed of many different kinds of trees, several of which give valuable hardwoods. Some of the tropical hardwoods are mahogany from the West Indies

Tropical

Forests and Central America, ebony from India, teak from

Burma and Java, greenheart from British Guiana, and rosewood from South America. The quest for sandal wood brought the earliest Europeans to the Solomon Islands, and it was the mahogany and logwood cutters in Central America who led to the foundation of British Honduras.

Temperate forests are composed of few species of trees. One kind is usually dominant throughout the forest and may even embrace over 90 per cent. of the trees. The soft-

Temperate Forests leaved forests are oak, elm, beech, maplc, lime and others. They are now best represented in the Alps, the Pyrenees, central Russia, the middle regions of Siberia, Japan, the Appalachian region in the United States, Patagonia, Fuegia, and southern Chile. In southern and eastern Australia there are great forests of eucalyptus. Despite the inroads on the oak forests in the past oak is still an article of trade in central Europe and in Canada. Elm, maple, birch, and walnut are also in some demand. Beechwood is used in making chairs while aspen is the best for match manufacture. The Australian eucalyptus forests furnish the hard jarrah and karri woods which are largely exported for paving blocks and harbour piles. Many other timbers have special uses.

It is, however, the temperate coniferous forests which are most important. Various kinds of pine and fir supply the soft woods

Timbers of Commerce which are the chief timbers of commerce. Besides the local use of these for fuel and building, enormous quantities are exported from timber lands to countries which lack a supply of their own, whether the industrial lands of Europe or the new countries of the southern hemisphere. The chief timber exporting countries of Europe are Sweden, Norway, Finland and Russia. Timber can be profitably exported only where there are easy means of bringing it to seaports. Waterways along which the logs can be floated in summer afford the cheapest transport. In this way many rivers, otherwise unnavigable and useless to man, obtain great economic importance. The winter snow in the forest lands gives an easy surface over which to haul 
the logs to the rivet banks. In many Canadian lumber districts the trees are felled in winter and hauled to the bank of the frozen streams where they wait for the spring floods.

As the nearer lands are more exploited, rcmoter forests come into the area of commerce. Already the vast forests of the Pechora basin east of the White Sea are being cut, but the forests of eastern and northern Siberia, except near the Pacific seaboard, remain untouched, safe in their isolation. It is estimated that Siberia contains about $1,250,000$ square miles of valuable timber, and that northern Russia has nearly 500,000 square miles.

Excessive felling soon destroys a forest. In the last century the world's timber resources have been so seriously depleted that on that account alone the price of timber has risen enorAfforestation mously. Most timber-growing countries are now trying to replant devastated areas, and protect young trees. Afforestation however is a slow task, and can only bencfit posterity. This generation has to pay for the follies of the last in order to save the next generation from want. The destruction of forests has a further effect than the mere loss of timber. By allowing the rain to drain off rapidly instead of soaking into the leafy soil and slowly percolating to the valleys, deforestation causes mountain torrents which sweep the soil off the hill sides and pile it up in the valleys, possibly destroying agricultural land. In this way the Romans did much to decrease the fertility of the Barbary States. But other agents besides man destroy forests. Goats were the principal agents in the destruction of the forests of Cyprus, Greece and Sicily : Morocco has possibly suffered in the same way. The island of St. Helena when discovered in 1502, was forested. The Portuguese thinking to do good to possible ship-wrecked or needy sailors in the future landed goats on the island, with the result that before long the young forest growth was destroyed and gradually the forests fell into decay.

Plants of economic value are found in every type of vegetation : even the Arctic tundra has its reindeer " moss." The people of Cultivation of every environment have discovered what kind of Plants plant supplies food. A later development was the cultivation of certain plants and their improvement by gradual selection of the best stocks until the present kinds of cultivated grains and fruits were evolved. Nearly all our 
cultivated food plants are prehistoric in origin : they reached more or less their present state, as compared with their wild ancestors, in the ages before human history was recorded. The wheat of ancient Egypt, from samples that have come down to us, was essentially the same as the wheat of to-day. In the Stone Age as many as five different varieties can be recognized as in cultivation in Alpine valleys. The cultivated banana was seedless as early as there were any records.

While the distribution of soil and climate were the chief factors which turned primitive man to the cultivation of crops as his principal livelihood, the distribution of possible

Cereal crops food crops must also be taken into account. Practically all the cereal crops, except maize, in their wild form were natives of Eurasia. This circumstance of course put agriculture at a great advantage in the early civilizations of the old world. Barley was probably the first cereal crop of the early Mediterranean civilization. It produces more grain per acre than wheat, yet wheat has largely replaced it for human food. Oats and rye are not well suited to the Mediterranean climate and are essentially crops of more northern latitudes with cooler and wetter summers. Maize or Indian corn is the only cereal crop which is a native of the Americas. The lack of indigenous cultivable grain in the new world undoubtedly had much to do with the slow progress and limited extent of civilization in America before its introduction, along with old world cereals from Europe. Maize requires a long hot summer with copious summer rains and abundant sunshine. It is rather a subtropical than a temperate crop, but too warm a summer hastens unduly the ripening of the grain and involves a loss in weight. At high altitudes in tropical zones, where elevation compensates in respect of latitude, maize gives the most abundant yield. Its wild ancestor probably grew on the Mexican plateau. It was under these conditions, with the help of irrigation, that maize was the staple crop of the indigenous civilizations of America, the Aztecs and Incas. Australia, when Europeans first discovered it, had no native food plants fit for cultivation ; and as we shall see later, no animal capable of domestication. With this poor endowment it is not to be wondered that Australia never gave birth to a civilization of her own: even with natives higher in the scale of 
human evolution it is doubtful if an Australian civilization would have independently arisen.

Africa had few plants fit for cultivation to offer the negro when he first peopled that continent. The yam, date palm, and certain species of millet were perhaps all. At an early date Arab slave raiders introduced to tropical Africa rice and sugar cane from India, and at a later period tobacco from America via Europe. Wheat, barley and other grains, as well as pumpkins, gourds, peas and beans spread from Egypt in prehistoric times. The Portuguese gave Africa manioc, ground nuts, sweet potatoes, onions, and maize, most of which they brought from Brazil. They are also supposed to have introduced one kind of monkey nut but another kind was native to Madagascar. Various fruits are also attributed to the Portuguese, such as the orange, lime, pineapple, and the tomato. Coffee and tea were late introductions to Africa.

An American geographer has emphasized the material advantages of the endowment of the old world (excluding Africa) in food plants by pointing out that within a radius of about a thousand miles of Nineveh were the habitats of the wild plants from which were cultivated wheat, barley, rye, oats, sesame, onions, garlic, beans, olives, date palms, figs, plums, apples, apricots, pears, cherries, peaches, most vines, coffee, flax, and several other useful plants. From the Malay Archipelago and adjacent lands came originally most of our spices ; from Assam came tea ; and from the East Indies rice. Tobacco came originally from America. The sugar cane probably came from Indo-China and at an early age spread westward, being brought from India to Egypt by the Arabs. America was the original home of the potato, sweet potato, and manioc or cassava, but the old world produced the other root crops. The tomato was American. Cotton and many other fibre crops came from Eastern Asia ; cacao from America. The best rubber-bearing trees are natives of Brazil. The cinchona, from the bark of which quinine is prepared, is native to Peru but has been introduced to Java, India, Ceylon, and Jamaica with great success. The vine has spread from the Near East to all climates suitable for its growth : new varieties evolved in America have been reintroduced into Europe and found to withstand the ravages of insect pests better than the original stock. 
Some industrial and other crops have not been improved by man and are used in their wild state even if grown in plantations.

Industrial Crops

Some are not food crops but supply material which modern manufactures demand in increasing quantities. In the main these industrial crops, as we may term them, are tropical crops. Their cultivation is the chief concern of the development of tropical lands by European powers and America.

The collection of edible fruits is practised by the most primitive tribes of hunters: the growth of tropical fruit trees from cuttings

Fruits of Commerce was very possibly the earliest form of agriculture and remains the only one in some environments. The growth of fruit for purely local uses enters little into the consideration of economic geography. But the considerable demands for fruit by the urban populations of industrial countries has caused a trade in fruit and led to fruit plantations on a large scale. The chief fruits of commerce are those which are resistant enough to suffer packing and carriage, like apples, and oranges, and lemons, and which gathered unripe attain their full flavour later. Thus many tropical and subtropical fruits are excluded while others like the pineapple (Azores), banana (Jamaica, Canaries, Central America), and coconut bulk largely in commerce. Soft berries like strawberries and raspberries can be carried only short distances. Fruits which can be dried without loss of flavour or with increased value are much in demand : dates from Persia and the Sahara, figs from the Mediterranean, dried grapes as raisins and currants from Spain, Greece, and Asia Minor, and nuts from the Mediterranean, Ceylon, Brazil, and the West Indies. The industry of drying soft fruits for export is confined to those lands which experience a long dry summer. Other fruits which will not keep long fresh are canned for export, such as the peaches and pineapples of California, the Sandwich Islands, and elsewhere. 


\section{CHAPTER IV}

\section{THE INFLUENCE OF ANIMAL LIFE}

MAN is in less close relation to the fauna of a country than to the vegetation. His intellectual powers and skill in the fashioning of weapons has made man more or less a match for beasts of prey. No lands are devoid of population solely on account of hostile animals. And yet beasts of prey exact a considerable toll on the life of man and his domestic animals. The construction of the Ugandá railway near Nairobi was delayed several weeks by lions attacking the Indian coolies at work. In India the annual mortality due to large tigers and panthers is said to amount to several thousand human lives and over 70,000 head of cattle. At different times in various lands head prices have been put on bears, wolves, and other animals with a view to their extermination. Venomous snakes account for some 20,000 human deaths a year in India : in other tropical lands the death roll is also heavy. Every country has its bird and insect pests which are injurious to crops, as well as those species which are beneficial and might with advantage be encouraged.

Many animals, in themselves harmless or even useful, may in certain circumstances become enemies to man. The goat, which is man's mainstay in certain poor pasture lands, is

Animals as Man's Enemies a great enemy to forest growth, and the rabbit although a useful food animal, is so omnivorous that farmers regard it as an enemy. The rabbit is a quick breeder : it has been calculated that, given favourable conditions, a single pair might increase in four or five years to a million. In Australia, where the conditions are ideal, a few pairs thoughtlessly introduced by early settlers have now multiplied to such an extent in some parts that whole countrysides are laid waste by their depredations. Efforts to exterminate them have failed : they continue to multiply and spread. The only protection against them is rabbit-proof fences, of which nearly 50,000 miles have been erected in New 
South Wales alone. In Western Australia a rabbit-proof fence, over 1,000 miles in length, crosses the country from south to north.

The common rat destroys food stores and standing crops and is a dangerous carrier of disease. It multiplies prodigiously in all lands. Measures taken to exterminate it promise to be quite futile and may merely lead to the more rapid multiplication of the numerous survivors. But human dwellings, possibly even towns, may be made rat-proof. It is less likely that efforts to prevent the transportation of rats on board ships will meet with success.

More insidious and difficult to combat are the insects which are now known to carry disease germs. It is only in recent years that the relation of the mosquito to malaria, yellow

Insects as

Germ Carriers fever, and other deadly diseases has been discovered. Mosquitoes are widely distributed throughout the world, from tropical to subpolar climates. In the tropics and the Mediterranean, eastern Europe and the Netherlands they are carriers of the germs of malaria of varying degrees of virulence. Yellow fever, which is the scourge of tropical Africa, Central and South America, Malaya, Indo-China and Burma, is carried by another species of mosquito. On the other hand in the Eurasian and American tundras, the swarms of mosquitoes seem to carry no specific disease although their irritation is maddening. A study of the natural history of the mosquito shows that the best way to exterminate it is to drain marshy lands or failing that to spread a thin film of oil over the water. By these means the health of many parts of the tropics and subtropical lands has been much improved. (See Chapter XIII.)

The tsetse fly of Uganda and other parts of tropical Africa carries the deadly sleeping sickness. Another species of the same fly attacks cattle but generally with less fatal results. The utilization of cattle in many of the grasslands of Africa depends on the extermination of this pest.

The distribution of the bacilli of tuberculosis, leprosy, plague, and other diseases which account for a heavy mortality, may be independent of geographical controls. Yet the spread of such diseases is an important factor in the distribution of mankind. 
An aspect of hunting dependent largely on the demands of civilized communities led to the extensive pursuit of fur-bearing animals. Many animals which live in cool,

Fur Trading temperate or polar climates develop a close covering of fur in winter as a protection against low temperatures. The fur industry must therefore be pursued under severe climatic conditions. During the polar summer the coats of these animals are of little or no value. The fur trappers of Canada were the first explorers of Arctic America and they soon rivalled in skill, endurance, and knowledge of woodcraft the Indian hunters themselves. The Hudson's Bay Company's forts or trading stations were pushed northward into the coniferous forests up to the shores of the Arctic Ocean. Many of the Canadian towns of to-day were originally fur-collecting stations and trading posts. Fur is the oldest established trade in Siberia, and many of the Siberian towns originated as fairs for skins, and retain that character to this day. Irbit, Yakutsk, and Nikolaevsk are still great fur markets. In European Russia the principal fair is at Nijni-Novgorod.

The demand for furs used to take Russian, and later Norwegian, trappers to Spitzbergen where the fur-bearing animals have been almost exterminated. Fur seals are hunted at the Commandcr and Pribilov Islands in the North Pacific. They are practically extinct in the Antarctic islands where they were previously hunted.

To meet the growing scarcity of valuable skins attempts are being made to breed Arctic foxes. Fox farms have been started in Labrador and Alaska, and there are proposals

Fox Farms to start them in Spitzbergen. The fur hunter is at length learning the lesson which his far-off ancestors on the central Asian steppe lands learnt in prehistoric days when they caught and domesticated their wild animals. There is no biological reason why animals should not be bred for fur-bearing qualities as well as for muscle, fleetness of foot, or quality of wool. Hunting must restrict its nomadic and progressively destructive nature if it is to survive. The sportsman shooting grouse on the Scottish moors realizes this, and hence the close scason which prevents the extermination of the birds. For the same reason restrictions of season have been placed on all the great sealing grounds. 
The slaughter of plumage birds is a kind of hunting which sup-

Plumage Birds plies a luxury trade, that fluctuates with the whim of fashion.

The sea teems with life and most seacoast peoples derive part or most of their nutriment from fish. Temperate seas are more prolific than tropical seas, probably because of the larger

Fish amount of vegetable life which is found in cool waters. Moreover, as in the case of forest trees in cooler climates, the number of individuals of fish is great and the species relatively few compared with the tropics. Although fish go to great depths in the ocean they seem to prefer shallow water. This is associated with the presence of waste material from the land which furnishes food if not directly to the fish at least to lower organisms on which the fishes live. A sea floor at no great depth probably also provides the most suitable spawning grounds.

The most important fishing grounds lie in the northern hemisphere and include the Newfoundland Banks, the North Sea, and the Sea of Japan. On the Newfoundland Banks,

Fishing Grounds where a cold Arctic current gives the death blow to the Gulf Stream, the mingling of waters seems to provide ideal grounds for cod. These fisheries have been important since early in the sixteenth century, when Norman and Basque fishermen first visited them. It was a traditional claim to her fishing rights that left France in possession of the small islands of St. Pierre and Miquelon when the rest of Newfoundland and all Canada passed to Great Britain. France also retained certain rights over the inshore fisheries on some of the Newfoundland coasts. The fisheries of the banks being on the high seas are open to all comers.

The North Sea fishing grounds are important principally for herring, haddock, soles, turbot, and cod. They are frequented by

North Sea

Fisheries all nations bordering the North Sea, many of whom send fishing vessels to the grounds around the Faroes, Iceland, and off the west of Scotland. Steam trawlers and drifters have largely replaced sailing boats except in the herring fishery, an occupation which migrates round the coast of Britain from the Hebrides to Yarmouth following the shoals. The larger trawlers capable of carrying 400 to 700 tons of 
fish stay several weeks at sea, keeping their fish on ice, but the smaller vessels which fish nearer home seek market more frequently.

The Norwegian fisheries, mainly pursued in sailing boats, are cod and herring fisheries along the coast. They form one of the chief occupations of Norway. The Baltic is

Norwegian Fisheries relatively poorly endowed with fish, its waters being only slightly saline and not favoured by most North Sea species. France has sardine fisheries on her Atlantic coasts and sardine and anchovy fisheries in the Mediterranean. But on the whole the Mediterranean affords poor fishing grounds, quite inadequate to supply the great demands of the many Roman Catholic dwellers on its shores. Much of the Newfoundland and Norwegian cod, dried or salted, finds its market in Mediterranean lands.

Much fish is also tinned for export, such as salmon in British Columbia and Alaska, sardines in France and Portugal, and young herrings in Norway. In the British fisheries the greater part of the catch is for home consumption although large quantities of salt herrings are exported.

Fishing causes the localization of people in suitable coves or inlets which afford harbourage for the boats. The best sailors are

\section{Localization of People} recruited from the fishing communities of any country. The men of Shetland, and of Cornwall and Devon have always had a great reputation as deep water sailors, and in France the Bretons are easily the best seamen. Life on a small fishing-boat, at sea in all weathers, is the best school for seamanship. We need only recall the services of the fishermen of Britain in the mine-sweepers and similar craft during the European war. As fishing-boats increase in size, steam replacing sail, and the cargoes obtainable are in excess of all local demands, the tendency is for the vessels to work from a large harbour which has direct railway communication with centres of demand. At such centres fish-curing works also arise, since, owing to the number of boats working from the port, they are assured of supplies. In this way Aberdeen has killed the small fishing ports along the coast from Stonehaven to Peterhead, and Peterhead in like manner has drawn to it the population of many small havens in the vicinity. 
Certain kinds of coast are unsuitable for fishing. These are generally high, rocky coasts without shelter in regions of strong winds. If the coastal lands are also unproductive,

Unsuitable Coasts as they probably are in these circumstances, population is scanty and often poor. On the other hand a low-lying harbourless coast, while unfavourable for fishing, is generally backed by a productive plain which makes the population independent of the resources of the sea.

Fresh water fisheries are not of great importance except in lands far removed from the sea. Sea fish have a finer flavour and are more in demand, with the exception of course of salmon, which is really a marine species that ascends rivers to breed. In the great rivers of Russia and Siberia, which flow through regions far removed from the sea, fresh water fisheries are of great importance. The roe of the sturgeon enters into commerce as caviare. The fisheries in the $\mathrm{Ob}$, Yenisei, Lena, and Amur, cause a migration of fishermen in summer, when the rivers are ice-free, to the mouths and estuaries, a sort of nomadic population of fishers and traders which recedes southwards in winter.

The term fisheries is generally used to embrace the capture of other marine animals besides fish, including oysters, shellfish, seals and whales. Whales are hunted in most of the

Whales, etc. oceans both for blubber, which is rendered to oil, and whalebone. The carcases are frequently used for the manufacture of bone manure. The Greenland or Right whale is now so rare in Arctic seas that it is no longer pursued. In the South Atlantic the closely allied southern whale is found. Both these are very valuable for the large amount of whalebone as well as oil which they yield. Various kinds of finner whales are now hunted in the Greenland Sea and North and South Atlantic. Their pursuit has brought human settlements to otherwise unpopulated islands like South Georgia and the South Shetlands. Three hundred years ago whaling gave rise in Spitzbergen to a summer town of 1,500 inhabitants but it has long since disappeared. Sperm whaling is followed in the tropical waters of the Atlantic, Indian and Pacific Oceans, generally by nomadic whalers, which remain at sea for long periods. Various kinds of seals are hunted for oil but excessive slaughter has much reduced the supply. 
Manykinds of molluscs, particularly bivalves, are fished in certain tropical seas for mother-of-pearl and pearls. The most important are now in various Pacific islands, the Malay Pearls Archipelago, northern Australia, and lower Burma. A marine invertebrate known as a holothurian, is cured as bêche-de-mer or trepang, in many eastern waters and finds a ready market among Chinese.

Man has a closer dependence on animals than in hunting and fishing. He has succeeded in domesticating and turning to his use certain animals either as beasts of burden or Man's
Dependence as food resources. Domestication is mainly conon Animals fined to herbivorous animals. They are comparatively easily tamed and thrive well in semicaptivity. It is interesting to speculate on the origin of the habit of domesticating wild animals. Man's natural affection for animals no doubt was a factor of importance; possibly also shepherding evolved from hunting. The fleet grass eaters on the open plains are very difficult to hunt and so made life most precarious to the hunter who depended on them for his food supply. This might easily suggest capturing the wild animals and breeding them in captivity. The dog was no doubt the companion of the early hunter and of considerable use to him both in chasing game and perhaps also as a scavenger in his encampment. Eskimo dogs are of great value in eating the offal of camp or village. The polar explorer, forced by hunger to kill and eat his faithful dogs, is perhaps recapitulating the habits of the first herdsmen: when hunger pressed the herds saved the tribe.

At a very early stage in man's story animals must have been tamed and used as beasts of burden and for labour in the fields. No ploughing on a large scale is possible without

Beasts of Burden help, and overland trade did not develop until animals were used for transport purposes. The successful management of herds of cattle and sheep was impossible without the help of horse and dog. Until quite recent times the main use of domestic animals was for transport and burden and, of course, many still are used for these purposes. There are parts of Burma and Malaya where the elephant is the only satisfactory carrier. The increasing utilization of mechanical power is now displacing the horse from the roads of many countries, and even 
ploughs are drawn by tractors. It is not improbable that in another generation the horse will be a comparatively rare animal in industrial countries like our own. Great importance used to be attached to the breeding of horses suitable for army purposes. In the European war, however, their value much decreased by the employment of motor transport and tanks. The ass and the mule are likely to survive in the drier, mountainous countries where their less fastidious feeding and their sure foothold on steep gradients and mountain tracks make them invaluable.

Meanwhile the breeding of cattle and sheep solely for food, and the institution of huge herds for this purpose in the new and little

\section{Breeding of Cattle} populated grass lands of the world, is a modern development of the pastoral life. It depends on the rapid growth in industrial centres of populations which produce no food directly and must draw on the surplus of other people. Imported food is the raw material which furnishes the necessary labour and skill. For the same reasons the tendency in industrial countries is always to grow fewer crops and to keep more land in permanent pasture. This gives a good profit to the farmer and necessitates less labour on the land. Of course the importation of fresh meat from overseas only became possible with the invention of refrigerating machinery and the construction of special vessels. These developments in mechanical skill gave a great impetus to meat eating in industrial Europe, especially Great Britain. A later phase in this intensive herding for meat production necessitates the growth of cereal crops to produce food for the herds. Thus in Iowa and Nebraska, in the United States, great areas are covered with maize which is harvested for fattening pigs for the meat factories of Chicago. Possibly as the new lands become fuller and the demand for meat increases, it will be necessary to keep larger flocks of food animals on a given area, and that can be done only by growing on the land more productive crops than pasture grasses. The great demand that grazing animals make on the land has long since led to their absence in the densely populated river valleys of China. The Danes, however, have shown how the cattle industry near the great industrial centres of Europe can be made very remunerative on comparatively poor soil. 
The production of quantities of milk is another function of the new lands where large herds of cattle are kept. For export the milk is either tinned, or converted into butter Milk

Production and cheese. Hence the great export of these commodities from North America, Siberia, Australia, and New Zealand, and the export of beef extracts from Uruguay. Rich pastures near centres of great demand prompt similar industries : Switzerland and Norway thus export condensed milk.

Herds of cattle, sheep, and other domestic animals yield many other products in addition to food. Wool, leather, horn, camel's Other Animal
Produets hair, etc., are all products of the world's grazing lands, and under certain conditions associated with the supply of fuel and labour lead to manufacturing activity. In other circumstances the raw material is sent to the place where fuel, labour, and technical skill are already located. 


\section{CHAPTER V}

\section{SOME IMPORTANT CROPS \\ FOOD CROPS AND STIMULANTS}

THE economic geography of certain important crops must be considered in relation to both their areas of cultivation and their entry into commerce. In the study of food crops it is necessary to bear in mind their relative food values. These are an important commentary on the local consumption, the import and export of food.

Without entering into problems of chemistry and physiology it may be explained that the principal constituents of food are proteins, carbohydrates and fats. Proteins, which

Food

Constituents are all nitrogenous, are flesh formers; carbohydrates and fats give heat and other forms of energy. All three substances are essential in a complete diet, but the relative proportions of each may vary widely with the conditions of work and environment. Food values are best expressed in calories, the calorie being a measure of energy. From a recent publication of the Ministry of Food the following table is extracted. A few foods of animal origin are added for comparison.

\begin{tabular}{|c|c|c|c|c|c|}
\hline & & Protein. & Fat. & $\begin{array}{l}\text { Carbo- } \\
\text { hydrate. }\end{array}$ & $\begin{array}{c}\text { Calories. } \\
\text { per } \mathrm{lb} \text {. }\end{array}$ \\
\hline Wheat flour & & 11 & 1 & 75 & 1,651 \\
\hline Oatmeal. & $\dot{0}$ & 15 & 8 & 60 & 1,732 \\
\hline Barley meal & : & 10 & 2 & 73 & 1,642 \\
\hline Rice . & . & 8 & - & 79 & 1,631 \\
\hline Maize meal & $\dot{0}$ & 7 & 4 & 66 & 1,544 \\
\hline Rye. & : & 12 & 1 & 72 & 1,625 \\
\hline Sago. & . & 9 & - & 78 & 1,635 \\
\hline Potato & $\dot{0}$ & 2 & - & 19 & 400 \\
\hline Carrot & $\dot{0}$ & 1 & 一 & 7 & 159 \\
\hline Turnip & $\dot{0}$ & 1 & - & 6 & 127 \\
\hline Banana & $\dot{0}$ & 1 & - & 14 & 298 \\
\hline Date (dried) & : & 2 & 2 & 69 & 1,421 \\
\hline Milk & . & 3 & 4 & 5 & 325 \\
\hline Butter & $\dot{0}$ & 1 & 85 & 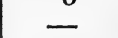 & 3,604 \\
\hline Cheese & : & 25 & 30 & 2 & 1,777 \\
\hline Egg . & . & 12 & 9 & - & 624 \\
\hline
\end{tabular}


From this table it is evident that there is little to choose in food value between the chief cereals except as regards oats, which lead in nourishing value. Rice and particularly maize Food Value of Cereals stand low and they are consumed almost entirely in warm countries where a less sustaining diet is required. The insufficient nutriment of a rice diet may not be unrelated to the lack of virility of the rice eaters in tropical deltaic lands. Root crops are poor foods and are always supplemented to a greater or less degree by cereals. Finland's population in the early history of the country used to subsist on turnips, and it was only at a later date when manufacturing industry brought the Finns the means to import grains that rye bread became their staple food. The natives of the Punjab live on millet, a cereal with a relatively low food value, exporting the more valuable wheat which they cultivate, to the rich industrialized countries of western Europe. Russian peasants (to speak of the pre-revolutionary era) used to grow wheat for export in the rich black earth lands of the south and lived on poor rye bread.

Wheat is cultivated in many varieties, most of which are the outcome of careful selection to meet varying conditions of soil and climate. Several of the chief varieties of wheat

Varieties of Wheat are of prehistoric origin and were cultivated by neolithic man. The number of varieties is being added to every year. All the varieties belong to the genus Triticum, a cereal of old world origin. Wheat cultivation has now been introduced to all lands which offer suitable conditions. The yield in grain and the value of the different varieties vary considerably, some being more suitable than others for flour milling. It must therefore be remembered that acreage is not the sole criterion of the success of wheat cultivation. A better estimate is derived from the number of bushels of grain per acre. ${ }^{1}$ This varies from an average of 32 in the best English wheat lands to about 9 in Ukraine and southern Russia. Low yield in some lands is attributable in certain cases to relatively unfavourable climatic conditions, and in other cases to a backward state of agriculture.

Generally speaking wheat requires a light clayey soil, but one that will drain well, allow the roots to spread, and afford easy

1 A bushel of wheat is 58 to 60 lbs. 
conditions of tillage. Like all grasses, it must have rain in the germinating season which should be fairly cool. This gives

\section{Wheat \\ Cultivation}

the best conditions for growth. The ripening period must be warm and dry, conditions which as a rule restrict the northward extension of wheat. A severe dry winter is hostile to winter (or properly speaking autumn) wheat, while a dry warm spring prevents the growth of spring wheat. In all cases an early and wet autumn is injurious to wheat cultivation : in England the chief wheat lands are in East Anglia, which is favoured with a drier and warmer summer than the west and north of the country. The Mediterranean climate, with its deficient rainfall amplified by irrigation, is an ideal one for wheat. The chief problems in the extension of wheat cultivation lie in finding varieties that will germinate with less rain and ripen with lower temperatures.

Wheat lands are found in the temperate, especially warm temperate, regions of the world. The most intensive cultivation is in densely populated parts of the northern hemisphere. In western Europe, although the wheat production is grcat, the import is considerable owing to the large manufacturing population which produces no food.

In 1914 , to take a year before the war conditions had seriously influenced the yield, the United States, with $891,000,000$ bushels,

was the greatest producer. This was nearly one

World's

Output of Wheat quarter of the world's output. A great but decreasing proportion of this is grown for export. Next came European Russia with $573,000,000$ bushels, mainly for export, France with $320,000,000$ bushels, for home consumption, India with $312,000,000$ bushels, chiefly for export. Asiatic Russia, mainly western Siberia, produced about $190,000,000$ bushels for consumption in Siberia and Russia, for the difficulty and cost of transport are too great to admit of profitable oversea export. Australia, in 1914, had an abnormally small wheat harvest owing to the prolonged drought; and the figures for 1915 , nearly $180,000,000$ bushels, give a better idea of the potentiality of the Commonwealth, although this was an exceptionally good year. This wheat comes mainly from Victoria and New South Wales. Italy yielded about $169,000,000$ bushels and the Argentine and Hungary each about the same amount, the latter 
two countries each having a large surplus for export. Canada's production was $161,000,000$ bushels and Germany's 146,000,000 bushels : in the case of Germany an insufficient amount to meet home demands. The yield of the United Kingdom was 62,000,000 bushels.

War conditions affected these figures in successive years. The Russian export supply failed, shipping difficulties and high freights decreased import to allied countries, but this was

Effect of

War Conditions balanced by more intensive agriculture at home. France had some of her best wheat lands ravaged by war. In 1917 the United States yield was only 650,000,000 bushels (but in 1918 it was increascd to $912,000,000$ bushels), the yield of France only $144,000,000$ bushels but that of India increascd to $379,000,000$ bushels. Australian ouiput was near its normal with $122,000,000$ bushels, the Argentine increased to 218,000,000 bushels, the Canadian to $234,000,000$ bushels, and that of the United Kingdom was $64,000,000$ bushels. The figures for 1918 showed a further increase all round but fell short of the high-water mark of production in 1913 when the world's total wheat crop reached over $4,000,000,000$ bushels.

For nearly a century the United Kingdom has preduced less wheat than is consumed at home. At present about 75 per cent. of wheat consumed in the United Kingdom is imperted.

In normal times the deficiency is met by import from the United States, Canada, India, the Argentine, Australia, and Russia.

In other words the exporting countries are either the new lands where agriculture is pursued on a large scale and food production is a staple industry, or those lands in which the population has teo low a standard of living to consume its own high-priced whcat. The import of cheap whcat from overscas much decrcascd home acreage during the last half century.

The high price of wheat has stimulated production in recent years and has increased the corn acreage in the United Kingdom. Home grown corn which has a relatively high cost of production can now hold its own with imported grain. That, however, is a condition of affairs that can be maintained only at the cost of the consumer.

Undeveloped wheat lands include grcat arcas in temperate South America, some of which are now used for cattle raising, 
large tracts in Canada, in northern, south and east Africa, and, with

Undeveloped

Wheat Lands irrigation, in Australia. Siberia and China will eventually produce greater quantities than at present but probably not for export.

Oats belong to the genus Avena, and are closely allied to wheat. Several varieties are cultivated, all of which mature best in a cooler and wetter climate than wheat and so on the whole 0ats are cultivated in higher latitudes. As a rule they do not grow so far north as barley, requiring a longer period of maturation. The Mediterranean climate, so favourable to wheat, is unsuitable for oats. This explains why the crop, although of prehistoric origin, seems to have been little cultivated until agriculture became general in northern Europe. The yield per acre varies from about 58 bushels in Belgium to as little as 16 or 17 bushels in the warm dry climates of Italy and the Argentine. Oats are one of the most nourishing cereals but few nations except the Scots have realized this truth. In most countries the main use of oats is for cattle and horse food.

The chief oat-growing countries are central and western Europe including the British Isles, and the northern United States and Canada. Production in the southern hemis-

World's Output of Oats phere is not of very great importance. The world's output of oats is about equal in number of bushels to that of wheat, but a bushel of oats is generally taken at $38 \mathrm{lbs}$. In 1914 the United States produced about one quarter of the world's output, Russia in Europe nearly as much, Germany about one-seventh, France about one-twelfth, and Canada a little less. The United Kingdom, with $161,000,000$ bushels, came sixth on the list. These proportions have been little altered by later conditions except that Canada now takes a higher place. France has a reduced output while Russian figures are unobtainable. The world's output of oats in 1917 showed a considerable increase over previous years.

Barley, which belongs to the genus Hordeum, is the most adaptable of cereals. Among its many varieties some thrive best in warm temperate lands and some are cultivated Barley farther north than any other cereal crop. It is a native of western Asia and was probably the earliest crop to be cultivated. In the Mediterranean climate it 
does best and produces more grain per acre than wheat. Barley was the chief cereal of ancient Mediterranean civilizations, but now is grown mainly in central and northern Europe where it still is important for human food. But generally speaking barley is now grown chiefly for the manufacture of beer and whisky. Imported wheat is taking its place as a food in Europe. Russia in Europe is the greatest producer of barley with about 25 per cent. of the world's output; next come the United States and Germany.

Rye, closely related to wheat and barley, belongs to the genus Secale. It is unknown in a wild state but probably grew originally and was first cultivated in south-eastern Europe. Rye It was not a crop of the ancient Egyptians. It is a hardy cereal and will grow on poorer soil than wheat and barley, but does not thrive far north, being injured by early frosts. In central and north-western Europe it was of old the chief cereal used for bread making. Rye bread is still much in vogue in Scandinavia, Finland, northern Germany and Russiaregions which have on the whole a poor soil and a climate unsuited for wheat. About 50 per cent. of the world's output of rye is raised in European Russia and 25 per cent. in Germany. Outside Europe there is relatively small production.

Maize, or Indian corn, a cereal belonging to the genus $Z e a$, is a native of America where it was cultivated in prehistoric times and was the basis of the indigenous civilizations Maize of America (p. 22). In the United States it is known simply as corn, in Europe frequently as Turkish or Spanish corn, and in South Africa as mealies. Corn flour and hominy are forms of maize.

There are several hundred varieties of maize which differ greatly in appearance, size, and composition of grain. All kinds require a long warm summer with abundant and frequent rains, much sunshine and a rich but easily drained soil. The amount and distribution of rainfall considerably affect the weight of the crop. Too rapid ripening gives a decreased yield. Consequently maize, although it thrives in tropical lowlands, is a more productive crop at higher altitudes or higher latitudes. It is essentially a warm temperate crop, and growing maize being injured by frost, it is a summer crop. The yield per acre varies from 54 bushels in 
Canada, to about 26 in the United States and 10 in European Russia.

The chief maize-growing country of the world is the United States, where it forms the principal cereal crop, and the yield is about 75 per cent. of the world's total. Ohio, Indiana, Illinois, Iowa, Kansas, Nebraska, and Missouri are the principal maize producing states. The last thirty years have witnessed a doubling of the area under maize, an outcome of the cattle and pig rearing for the export of meat. The Argentine output is increasing, and is about one-eighth that of the United States (1914). Hungary, Rumania, and Italy (particularly Lombardy) also produce much maize, and many parts of South Africa, especially Rhodesia, have growing importance.

Maize is not very suitable for bread making, but in Rumania, Italy, and Mexico it is a staple cereal, and in the United States and South Africa a certain amount is used for human food. Its importance in commerce is as a food for livestock.

Rice is a cereal belonging to the genus Oryza. It came originally from the East Indies and was cultivated in the earliest times.

Over a thousand varieties, differing in yield and Rice in the size and composition of the grain are known, but all require a tropical climate.

Rice needs a high summer temperature and a great amount of water during the growing season. Satisfactory cultivation entails growth actually in a few inches of water until near harvest. Under these circumstances its growth is so rapid that two or three crops can be gathered from the same land in the course of a year. The best results are secured in tropical deltas and alluvial plains where irrigation is possible. The abundant return accounts for the great density of population in such lands as the river plains and deltas of the Ganges, Yangste, Hoang Ho, Mekong, etc. Beans and peas grown alongside furnish the nitrogenous elements in which rice is deficient and so allow the rice cultivators to flourish on a vegetarian diet and one that takes less space to grow than a mixed diet of cereals and meat: hence increased density. With the use of less primitive methods of cultivation and the application of manure and machinery the output of rice could be considerably improved, but the peasant cultivators are conservative and loth to depart from immemorial precedent. A variety of rice known as hill rice 
grows under cooler conditions in a drier soil at elevations of several thousand feet, but is of comparatively small importancc. Rice, before the removal of the husk, is known as paddy.

Rice is distinctly an Asiatic crop and was only introduced to Europe in historic times. The Po valley in Italy, which is the

Cultivation
of Rice

principal European rice region, has grown it only since the Middle Ages. Its cultivation began in America soon after the foundation of the first English colonies. While rice is one of the most important of the world's crops and the chief cereal crop of Asia, it must not be assumed that all the population of Asia, even the subtropical and tropical parts, are rice eaters. In India only/about one-third of the population subsists on rice; in China a larger proportion. The inhabitants of Japan, Indo-China, Siam, and the Malay States and islands live mainly on ricc. Many of these countrics have to import rice to meet the home demand. Production is greatest in China, India, including Burma, Indo-China, Siam, Japan, and Java. In Europe the use of rice for human food is subsidiary to that of other cereals : a good deal is used in making starch.

Rice is one of the tropical crops cultivated on a large scale for the direct use of the cultivators: most tropical crops are mainly for the benefit of the inhabitants of temperate zones.

Millets include several cereals grown in tropical climates without the aid of irrigation. They are especially characteristic of India where they include Great millet or Guinea corn, Millets bulrush millet, and ragi. Millets demand much the same conditions for growth as maize. They are the staple food of all India outside the rice lands. In China, and in parts of Africa, millet is also used for human food. Durra and Kaffir corn are African names of millets. A species of sorghum is used in the United States and elsewhere as fodder.

Sugar cane is a grass native to southern Asia which has now been carried to all parts of the tropics. It is the juice of the stem and not the grain which gives this grass its value.

Sugar Cane Conditions of luxuriant vegetative growth are therefore of chicf importance. The plant is propagated from cuttings and not sced, which seldom mature in the cultivated plant. It is perennial and one plant bears shoots for many years, but since their value decreases it proves most 
economical to renew the plants every three or four years or even annually.

The climatic conditions required by the sugar cane are a long warm season with a temperature of $75^{\circ}$ to $80^{\circ} \mathrm{F}$., rainfall not less than 60 in. a year, and abundant sunshine especially at harvest time. These demands resemble those made by rice, but are less exacting as regards moisture. Irrigation is commonly employed on sugar plantations. Rich porous soils near sea-level are best for sugar, which does not succeed in hilly ground.

The demand for sugar in Europe dates from the Middle Ages, when it was introduced by the Arabs. In their days of greatness the Portuguese took it to Brazil and the Spaniards to Central America.

India and Java are the largest producers of cane sugar, but Cuba and Java are the largest exporters. Much sugar cane is grown also in Hawaii, the West Indies generally, the United States (principally Louisiana), Guiana, Brazil, Peru, the Argentine, Formosa, the Philippines, Queensland, Mauritius, and Natal.

The world's output of cane sugar has greatly grown during the last half century but would be quite unequal to the demand if it were not that beet sugar is now manufactured in large quantities. During and subsequent to the war, when supplies of beet sugar were cut off from the British Isles, the sugar shortage was keenly felt. The increase in post-war production of cane sugar is outbalanced by the reduced production of beet sugar and hence the continued deficiency in sugar supplies.

Beet sugar is a modern product. The first factory for the extraction of sugar from beetroot was erected in Germany in the end of the eighteenth century. Germany has always

Beet Sugar led in the output of this commodity. The manufacture of beet sugar not only popularized and cheapened sugar, making it a substance in universal demand, but by rivalry stimulated the cultivation of sugar cane. The sugar beet is a temperate crop and was probably derived by cultivation from a wild beet growing in Mediterranean lands. Several varieties have been evolved, including the mangel-wurzel and other food crops. The method of utilizing the beet means that it must be replanted every year, thus demanding more labour than the perennial sugar cane. The climatic requirements are a warm moist 
summer and a cool dry autumn. Too warm a summer and autumn is said to result in decreased yield of sugar even if the beets are larger. Soil must be well drained and well manured.

Beet is not so rich in sugar as cane, but careful selection and breeding have produced a beet with much higher sugar content than of old. It requires much more labour in planting and cultivation than cane but has the advantage of yielding a refuse, beet pulp, which is useful as cattle food. Further comparisons are that beet is grown where labour is dear but markets near at hand, while cane is grown where labour is cheap but markets are at some distance.

The leading country in the manufacture of beet sugar is Germany. Cecho-Slovakia, Hungary, France, Russia, Spain, and Belgium produce smaller amounts. The acreage in Europe under sugar beets in 1920 was 50 per cent. less than in 1914.

Experiments in beet growing have been tried in eastern England, and although it seems probable that deficient sunshine may result in a low percentage of sugar in the beets, there is not yet sufficient evidence on which to forecast the future of the industry.

The production of beet sugar and indirectly cane sugar, has been much influenced by Government action. The whole history of the fiscal regulations in Europe is very complicated, but briefly it amounted to a protective duty to keep out cane sugar and stimulate the beet sugar industry, followed by a bounty on export sugar which still further encouraged production. This led to large imports of beet sugar to the United Kingdom accompanied by a corresponding depression in the cane-growing islands of the West Indies. Eventually, however, the matter was settled by European states agreeing to stop export bounties. This raised the sugar consumption in the beet-growing countries and saved the West Indian cane plantations from collapse.

Vegetable oils are of growing importance. They are used in the manufacture of oil cake, margarine, etc., as well as soap, and so may be included under the heading of food Vegetable 0ils crops. They are derived from a number of plants, some temperate and others tropical in distribution. Of earliest economic importance was the olive tree, a native of Mediterranean lands and thriving best in the peculiar climate which obtains there. The oil from the fruit of the olive 
has contributed to the growth of Mediterranean civilization in supplying man with necessary fats which are lacking in a region where the conditions are adverse to dairy cattle and consequently butter. Most Mediterranean lands, especially Italy, France, Spain, and Asia Minor, produce large quantities of olive oil. Cotton seed oil comes from Egypt and the United States. Rape seed oil, derived from a species of mustard, is a temperate product and used chiefly as a lubricant. Linseed or flax seed oil is used in making oil cake for cattle as well as in the manufacture of paints, varnishes, and linoleum (see p. 53). Sesame is an important oil seed grown chiefly in India and Ceylon for local use.

The resources of the tropics in oil yielding plants are cnormous, and capable of great development. Coconut oil is produced from copra, which is the dried kernel of the coconut palm. Copra is the chief commodity of commerce in the Pacific Islands, for the palm, which requires a tropical climate, prefers a situation near the sea.

Coconut plantations have brought into prominence many islands, otherwise of little or no value to man. Coconut oil is much used in margarine, soap, and candle manufactures. The yield of Ceylon is considerable. Palm oil is one of the oldest trade resources of West Africa, and still the most important. It is derived almost entirely from wild trees and the industry is dependent on native labour, which is very wasteful in the extraction of the oil.

Another West African oil of great importance is ground nut oil. The plant is a native of South America, and Africa owes it to the early Portuguese traders. It is now grown also in India and in the southern United States.

There are many other vegetable oils of minor importance.

Coffee is derived from the fruit of a shrub which is native to the highlands of north-eastern Africa. The chief species in cultivation are the Arabian or highland and the Liberian or Coffee lowland, of which the former gives the finer coffee and is most in demand. From Arabia, to which the plant was introduced, coffee became known to Europe, but its use in Europe did not become prevalent till the seventeenth century. The popularity of coffee soon led to its wide cultivation in suitable climates and soils in the East Indies and tropical America. Coffee requires a rich soil, a warm but not necessarily hot climate, and a 
moderate supply of moisture. High winds and frost are both fatal. The plants when young must be sheltercd from strong sunshine, and with this end in view bananas, erythrinas, or other shady trees are planted on coffee estates. The Mocha plantations, which are near the sea, are shaded with wonderful persistence by sea mists during the great heat of the day. Three to five years are required for the plant to mature, after which it bears for some thirty years.

Coffee is a tropical product grown almost exclusively for export ; in most lands the large output depends on the supply of abundant cheap labour. The demand for coffee has done much to develop certain tropical lands like Ceylon and Brazil. In Ceylon coffee was the first crop to succeed on a large scale : by the middle of last century the coffee planting mania almost paralleled a gold rush in the scramble for land. But in 1870 the coffee leaf disease appeared and devastated the plantations. In ten years' time the planters, faced by ruin, turned to cinchona and later tea (see p. 46).

Brazil, especially the State of Sao Paulo, grows more than half the world's coffee. At an altitude of 1,800 to 2,500 ft. the coffee thrives best, that is to say in a climate where white labour, especially Italian, is successful. About half the world's coffee is exported from Santos and Rio de Janeiro. The highlands of Colombia, Venezuela, Central America generally, Haiti and Puerto Rico produce much coffee. Java and southern India are also coffee exporters. Comparatively little coffee comes from Arabia (Yemen), but it is of a very high quality. No coffee can be grown in temperate regions where the great demand for it occurs.

Tea is derived from the dried leaves of a shrub which is probably a native of China or possibly India. It has been in domestic use in China from the earliest times, but Europe did Tea "not know it before the seventeenth century while its common use in Europe was a century later. The tea plant has a wide range in subtropical climates, preferring those which are warm, moderately damp, and fairly equable. Excess of moisture is harmful so that well drained slopes afford the best sites for tea cultivation. The plant can survive exposure to frost. There are several varieties of tea plant, but the various kinds and grades of tea on the market are due principally to choice of leaves and process of manufacture. The finest tea, flowery Pekoe, is made only from the leaf buds at the tips of young shoots. 
Green tea is withered by steaming before fermentation has set in. The tea plant requires careful pruning and is ready for picking in three to five years. Cultivation and picking both require much labour and careful work. It is in those subtropical lands which have abundant cheap labour that tea is a productive crop.

Southern China is the greatest tea growing country and used, until some forty years ago, to supply the world's demands. Tea compressed in bricks used to be one of the great commodities of overland trade to Tibet, Mongolia, and via Kyakhta to Siberia and Russia. The great demand for tea in Europe in the middle of last century, when the import duty fell to a reasonable figure, before the Suez Canal was built, led to the construction of famous tea clippers which raced from China to Europe in ninety days, a speed never surpassed by sail. The object was to expose the tea to as short as possible a period of sea transport in order that its quality might not deteriorate. The home consumption of tea in China is very great, and exports have fallen off in the face of the competition of India and Ceylon which now supply most of the tea used in Europe. In India, Assam, the Darjeeling district, and the Nilgiri Hills grow large quantities, and since the failure of coffee (see p. 45) Ceylon has been a great producer. Above an elevation of 2,500 ft. tea is practically the sole crop in Ceylon. Tamil coolies from southern India supply the labour. Japan, where the cultivation has been long established, and Java, where it is relatively new, export large quantities. There are also tea estates in Natal, Brazil and California. The Australians, New Zealanders, British and Canadians are the principal tea-drinkers. The import to the United States shows much increase and will no doubt grow rapidly as a result of alcoholic prohibition. India's consumption is also growing. There seems in fact to be every likelihood of a shortage in the world's supplies within a few years. Production will be increased in India, Ceylon, Java and Sumatra, but it is doubtful if the increase can keep pace with the demand.

Cocoa and chocolate are derived from a tree which is native to tropical America. The valuable product is the fruit. The cacao tree needs a warm, damp climate with good rich Cocoa soil, shelter from winds and direct exposure to hot sunshine. Erythrinas and rubber trees are generally grown among the plantations to afford shade. Cocoa 
is essentially a plant of equatorial regions. Compared with coffee or tea, cacao requires comparatively little labour and so can be cultivated successfully in tropical America and West Africa. When the Spaniards came to America they found chocolate in use, and several of the chief areas of cultivation of the tree are still in America. The Gold Coast now leads in production, followed by Brazil, Ecuador, the West African islands of Sao Thomé, Principe, and Fernando Po, Trinidad and the West Indies. Ceylon and Java are also cocoa growers, and a beginning has been made in Uganda and the Fiji Islands. Most of the cocoa grown is sent to the United States, Britain, Germany, the Netherlands, and other parts of Europe.

Wine is the fermented juice of the grape but the name is also used to some extent for the fermented juice of other fruits. The vine is native to eastern Europe and western Asia, Wine but other species are natives of North America. In the eastern Mediterranean it was one of the first plants to be cultivated and it has now been carried to all suitable climates. There are many varieties, all of which require a long, warm, dry summer for the maturation of the grape. The northern limit of the vine is fixed by this consideration. Drought in summer is not harmful since the long deep roots of the vine draw moisture from the subsoil. Southward facing slopes are very favourable sites for vineyards for they drain well and have plenty of sunshine. Hence the predominance of vine cultivations in river valleys. Soil is also a factor of importance for the vine requires ground that is fairly retentive of moisture but never becomes waterlogged. The plants being leafless in winter are not injured by frost. The vine seems very susceptible to the attacks of certain plant and animal diseases. Phylloxera, an insect pest, ravaged the vineyards of many parts of France some thirty to forty years ago, with the result that the American vine, being less liable to attack, was introduced to redeem the wine industry from collapse. The American vine proved so fruitful that there was for some years a tendency to over-production of wine. Phylloxera occurs, but is now under control, in Australia and South Africa.

The vine is now cultivated principally, but not solely, where the Mediterranean climate obtains. The names of wines are derived as a rule from the localities of manufacture, such as champagne, 
bordeaux or clarets, rhine wines, port, madeira, etc. Variations of climate and soil, local skill, and methods of manufacture account for the differences in wines. The vintage changes in quality from year to year. France and Italy are the greatest producers of wine. Spain, Austria, Hungary, Algeria, Portugal with Madeira, and Germany are considerable producers.

In spite of high production in most years a considerable quantity of spurious wine of chemical preparation is on the market.

Tobacco is prepared from the leaves of plants which are native to tropical America. Several species are known. Tobacco was in use throughout the Americas before their disTobaceo covery by Europe, and it has now spread throughout the world, in some instances as in central Africa, by barter from tribe to tribe going ahead of European exploration. Although a tropical plant, tobacco has a very wide range, being grown in all parts of the world except the hot and cold deserts. It is injured by frost and requires a warm summer for the proper maturation of the leaf. A rich soil, well drained, with much lime and potash is necessary. Tobacco will grow outside the regions of commercial cultivation, but it fails to produce a leaf of any value, e.g., Irish-grown tobacco. Variations in kind and quality of tobacco depend on the species cultivated, the soil and climate, the choice of the leaves and methods of preparation. The cultivation and preparation of tobacco require a considerable amount of labour, but the dried leaves are generally exported unmanufactured to the countries of demand. The United States (Kentucky, Virginia, etc.), are the chief producers and exporters. A great deal is produced also in India, Russia, Cuba and other West Indian islands, the Malay Archipelago, especially Java, Sumatra and the Philippines, Brazil, Japan, Germany, Hungary, etc. Tobacco growing in Rhodesia promises well. Tobacco was one of the earliest commodities imported to Britain from America: its effect on the fortunes of Bristol has been very marked. 


\section{CHAPTER VI}

\section{SOME IMPORTANT CROPS}

\section{INDUSTRIAL CROPS}

UNDER this heading may be grouped those crops which are not cultivated for food or stimulants but provide the raw material for manufactures. Many food crops provide material for manufactured food products while they are, of course, the raw material by which human energy is produced and mankind maintained. The distinction between food crops and industrial crops may be more convenient than real as far as the term "industrial" goes, but the contrast has geographical value and so can be justifiably maintained.

Industrial crops are in few cases equal in antiquity to food crops, for they were not cultivated on a large scale, if at all, until modern industry had created a demand. The list is a Demand for long one and is being added to in every generation
Raw Material as manufacturers seek new sources of raw material. It is only necessary to recall the growing demand for rubber and the search for new kinds of rubber trees, or the large scale experiments recently made, when coniferous timber was scarce in war time, to find suitable fibres for paper-making. Sometimes the problem is reversed, and a use is sought for an abundant material with a view to developing the country where it grows. A large demand for the southern tussock grass might be a new source of prosperity to the Falkland Islands, South Georgia, and other poorly endowed lands.

Silk, a fibre of animal origin, is conveniently included in this chapter. Wool is mentioned under Animal Products.

Rubber, india rubber, or caoutchouc, has only recently become an important commodity of commerce. In origin it is the latex or sap of several species of tropical trees, including Rubber the Hevea braziliensis of Brazil (Para rubber), the Manihot spp., also of Brazil (Ceara or Maniçoba rubber), the Castilloa elastica of Central America (Mexican rubber), the Ficus elastica (Indian or Assam rubber), the Landolphia spp. 
(African rubber), the Funtumia elastica (Lagos rubber), etc. Para rubber is the best and is most in demand, but the name "india rubbcr" suggests that it was from India that the substance was obtained originally. It is not many years since all rubber was gathered from wild rubber trees by the native population of the region. This satisfied demands for a time but year by year necessitated new areas of forest being exploited since the rubber gatherers in tapping the trees were careless whether or not the trees survived.

Population in the thick tropical forests, where the best rubber species grow, is not dense, and as the demand for rubber for industrial purposes grew there tended to be much exploitation and brutal treatment of the natives in the hope of increasing the amount of rubber they collected. Native labour only can be employed for this work, and the forest native takes unkindly to arduous toil. Force was employed when inducement failed in many cases.

The supply of rubber can no longer be maintained by exploitation of wild trees, which after all is a wasteful use of the world's resources. Plantation rubber for some years has been inSupply of creasing in importance. After a failure with
Rubber Ceara rubber, Para rubber trees were planted in Ceylon with great success. A suitable environment has also been found and largely utilized in the Malay Peninsula, Sumatra, Java, and to a less extent in India. Para rubber thrives in a moist equatorial climate and grows best near sea-level. The castilloa or Mexican rubber requires less moisture and lower temperatures, and can thrive in poorer soil. It is cultivated in Mexico where labour is neither abundant nor cheap as it is in Ceylon. Labour is saved by the less frequent tapping of the latex which suits this tree.

In the West Indies there are plantations of lagos rubber, and some other tropical lands have made a beginning with one or other species of rubber tree. There are possibilities of great increase in rubber production.

More than half the world's supply of rubber is still from wild sources. Brazil overshadows all other countries in annual output. Far inferior in output come the Congo and the Malay Peninsula and Archipelago. 
Colton is obtained from the fibres surrounding the seeds of the cotton plant, a shrub of the genus Gossypium, of which several different species are cultivated. Uncertainty Cotton envelops the origin of cotton cultivation. Two of the thrce cultivated species are natives of the old world, India and Egypt possibly, and the third, now known as Barbados or sea island cotton, seems to be a native of South America. The American "upland " cotton, however, is an introduced species in the new world. Cotton was cultivated in prehistoric times at least in India, and was introduced to eastern Mediterranean lands in a very early period. The various species of cotton show differences in length and texture of the fibre. Even in the same species these qualities vary with soil and climate.

Cotton is a subtropical crop adaptable to a considerable range of climate provided that the summer is long and there is no chance of frost. An equable warm climate without excessive moisture suits it best. Roughly speaking, suitable lands lie between the northern and southern isotherms of $60^{\circ} \mathrm{F}$. mean annual temperature. Since bright sunshine is essential the requisite moisture is best supplied in many lands by irrigation. A light warm soil with limey constituents facilitates growth. The black volcanic soil of the north-west Deccan, with its tenacity for moisture, promotes cotton cultivation in the dry climate of peninsula India. The long stapled sea-island cotton thrives under moister conditions than the other species and seems to derive benefit from a saline atmosphere and soil. Other cottons are cultivated with ridges intervening between the rows, to facilitate drainage, in wetter districts.

The medium and long stapled cottons are the latest varieties and frequently tend to revert to the original short stapled variety. Carelessness in selection of seed leads to this reversion which has occurred in India and reduced the value of Indian cotton.

Cotton is generally grown as an annual which allows of a great extension of the cotton area since winter climatic conditions are of no account in a crop sown and harvested the same summer. Successful cotton cultivation requires abundant cheap, but not necessarily skilled, labour, especially in picking. 
The greatest cotton-growing country is the United States, where the cotton belt covers the warm temperate states between the Gulf of Mexico and lat. $35^{\circ}$ to $37^{\circ} \mathrm{N}$., and extends Area Under Cotton from the Atlantic to about long. $97^{\circ}$ or $98^{\circ} \mathrm{W}$. However, the best American cotton is the seaisland cotton grown in northern Florida, Georgia, and South Carolina. Negro labour is a great asset in American cotton fields. In the United States, especially in the Mississippi valley, the production per acre averages about $200 \mathrm{lbs}$. and there are about 53,000 square miles under cotton. The cotton lands could be increased tenfold in area. The production in 1918-1919 was some $11,600,000$ bales of $500 \mathrm{lbs}$. each.

Indian cotton comes from the Deccan, the Punjab, and the northwest provinces. As mentioned above, it is of poor quality with an average yield of only about $100 \mathrm{lbs}$. per acre. Efforts are being made to improve the yield by the selection of better stocks, improved methods of cultivation and preparation, and so forth. The acreage is about 40,000 square miles and the yield in 1918-19 was $3,600,000$ bales of about $400 \mathrm{lbs}$. each.

Egypt produces the most luxuriant yield per acre and its cotton is of fine quality. Cultivation, which is confined to the delta and lower Nile, is dependent on irrigation. The crop averages some 500 lbs. per acre. There are over 2,000 square miles under cotton and the yield in 1918-19 was 4,800,000 bales of about $400 \mathrm{lbs}$. each. The area under cotton in Nigeria is growing. Uganda, the West Indies, the Egyptian Sudan, Rhodesia, Peru, Brazil, Turkestan, and notably Japan are among other cotton producing countries.

The shortage in the world's supplies of cotton, the increasing home consumption of the United States and India of their own

Cotton Supplies British Empire. To the efforts of the British Cotton Growing Association are due the cotton yields of our tropical African and West Indian possessions.

The use of manure considerably increases the yield. In Egypt the yield can be thus increased by 30 per cent. In the United States phosphatic manures are employed. 
Fluctuations in the price of raw cotton naturally have much influence on the area put under cultivation. Some years ago overproduction led to a slump in prices, but now that prices have increased new plantations are being started.

The chief exporting countries are the United States, through such ports as Galveston, New Orleans, Charleston and Savannah ; Egypt from Alexandria, and India. China is a great producer but retains its cotton for home use. Japan takes over 50 per cent. of its raw cotton from India.

Cotton manufactures in England date from nearly three centuries ago when they began in Lancashire, where they are still centred, but great progress dates from the industrial revolution and the invention of various mechanical devices to facilitate spinning and weaving. Lancashire now owns considerably over one-third of the world's total of spindles.

Flax was one of the earliest vegetable fibres to be used in textile manufactures. A native of south-western Asia, it has been cultivated in Europe from prehistoric times, and was Flax used by the ancient Egyptians in the making of linen. Soon after their foundation it was introduced into the European settlements in America. Flax is a temperate crop thriving under a wide range of climate, but requiring a moist and fairly rich soil. The soil is soon impoverished unless its value is restored by manure or a long alternating period of other crops. Flax is more difficult to grow than cotton, and is an uncertain crop showing great variability in the product. It is grown either for the seed, which produces linseed oil (p. 44) or for the stem in which the fibres lie. Both products cannot be gathered from the same crop as the methods of cultivation and harvesting differ widely in the two cases. The necessity for much labour in flax cultivation largely confines the crop to those lands where there is a dense population with a low standard of living, such as India, Russia, northern Italy, and Ireland. In Ireland, Russia, Esthonia, central Europe and northern Italy flax is cultivated for fibre: in India, the United States and the Argentine it is grown for seed, either because the summer is too warm to favour good fibre growth or because abundant labour is lacking.

Linen is manufactured chiefly in and around Belfast, in parts of Germany, in France in and around Lille and Cambrai, and in 
Belgium and Flanders. Linen manufactures have for long been decreasing at the expense of cotton which is cheaper and easier to produce and manufacture.

Hemp is a coarser fibre than flax and is used for strong fabrics like canvas and also for ropes. Ordinary hemp (Cannabis) is a warm temperate crop native to central Asia and Hemp growing under much the same conditions of climate and soil as flax. Its short growing scason allows it to thrive far north. Russia, Ukraina, Hungary, and Italy are great producers of hemp. It is also cultivated in India and China, and the Unitcd States; in the last in rapidly decreasing quantity owing to the competition of other fibres.

Several other fibres are also known as hemp, including the New Zealand flax (Phormium) which is little used, Manila hemp and henequen or sisal hemp. Manila hemp comes from a species of plantain or banana. It requires a tropical climate and comes chiefly from the Philippines. Being strong, tough, and flexible, it is used for cordage and ship's rigging. Sisal hemp comes from several species of Agave. It is grown in Yucatan, the West Indies and Hawaii. Its use is principally for sacking and twine.

Jute is a fibre obtained from two species of Corchorus, native to south-east Asia. These plants require a hot damp climate and are cultivated for fibre in Bengal, China, and Formosa. Jute Export on a large scale is confined to Bengal, and is of comparatively recent date, the whole crop being used of old in India. At present the home consumption in Bengal is increasing as modern factories are being founded. The area under jute is very considerable, being in Bengal alone over 1,500 square miles. Next to cotton it is the most important tropical fibre crop. Jute is manufactured principally in India (Calcutta and vicinity), Scotland (Dundee), Belgium (Ghent), Germany (Brunswick). It is used mainly in the manufacture of sacking and similar coarse fabrics.

Silk is a fibre of animal origin, being derived from the silkworm, but it may conveniently be included with industrial crops since its production is dependent on the cultivation of the Silk mulberry tree. Silk is also obtained from other silkworms but these are little cultivated. The climatic range of the mulberry is wide as it can be grown in most 
subtropical and warm temperate climatcs, but the silkworm can be reared only where a second crop of leaves is obtainable. This restricts silk production to those lands having an average temperature of $55^{\circ} \mathrm{F}$. for about three months. The successful production of silk is dependent also on other factors. Much work of a careful and delicate nature is required which can be best supplied by women and children. On the other hand silk is one of the few commodities for which considerations of transport have little significance. Being light and valuable in proportion to its bulk, it can easily bear the cost of high freights, and so its production at a distance from water transport is quite practicable: In the early trade between the Far East and Europe silk was one of the commodities desired, the Chinese having grown it from the earliest times. China and Japan are the chief silk producing countries, but Italy is not far behind. The production of southern France has not recovered from the decline due to the destructive silkworm disease experienced about half a century ago. Asia Minor, Persia and India are among other silk producing countries. The great silk importing and silk manufacturing countries are France and the United States.

Paper-making fibres are of vegetable origin. Coniferous timber chiefly of spruce supplies most of the material, but esparto grass from northern Africa and southern Spain is very Paper-making Fibres important. Cotton, flax, and sometimes wool are used in the shape of rags. Experiments in the utilization of various other fibres have been made. In China the bark of the paper mulberry and in Japan seaweed is used. Straw is used for the coarser kinds of cardboard. The great demand for paper in the nineteenth century-due largely to the growth of the newspaper press-gave pre-eminence to the cheap paper produced from timber. The countries with coniferous forests found a new source of wealth. Norway, Sweden, Finland, Russia, Newfoundland and Siberia produce most of the pulp wood. Exports take the form either of the wood, or more usually of pulp, both mechanical and chemical. Water power is utilized to manufacture the pulp, which allows the fibre to be exported in a less bulky and so more economical form. The United States produces large quantities of pulp for its own use and imports further supplies from Canada. 


\section{CHAPTER VII}

\section{LIVE STOCK AND ANIMAL PRODUCTS}

THE domesticated animals are comparatively few in number and very widespread in distribution. They alone, if fish is excepted, contribute materially to the animal food of man. Most if not all of these animals provide not only food for man but also raw materials utilized in various manufactures. Some general considerations bearing on the distribution of live-stock have been noted in Chapter IV. Continual attention to breeding and the improvement of stocks, and the study of the diseases of domestic animals have already led to marked improvements in all progressive countries and promise developments in the future. Biological discovery and live-stock rearing owe much to one another.

Cattle have been domesticated from several wild species and are all essentially lowland animals with the exception of the yak of Tibet and Mongolia and a few other local varieties. Cattle Many breeds of cattle, especially the common species, are known. Generally speaking, cattle are bred for either meat or milk. Somewhat different conditions are required for the two types, although both have to be well fed. Cattle kept for meat are found as a rule in the newer countries where abundant natural pasture occurs, while dairy cattle are more numerous in the older and more densely populated lands. By reason of limited pasturage they often have to be fed on root crops, oil cake, and imported fodder. In Denmark, where the keeping of dairy cattle has reached the high level of perfection, about half the crops raised annually are used for cattle food. The state of the dairy industry in Denmark proves that milk cattle are not confined to the richest pastures although rich pasture land, near great industrial centres, naturally favours the production of milk and consequently the manufacture of butter and cheese. In England the regions famed for dairy farming, such as Cheshire and Devonshire, owe their pre-eminence to a rich soil and a mild wet climate. On poor pasture cattle thrive but have to be fattened on richer pasture before being slaughtered for beef. Thus cattle are reared on the dry ranching lands of the "range country" of 
the western United States and brought eastward to be fattened on maize. Irish "store" cattle from the lime-stone plains are exported to England for fattening on richer soils.

Cattle are animals of temperate climates but thrive in dry tropical regions such as India, the Sudan and East Africa. Insect pests are more injurious than adverse climatic conditions (see p. 26), but in warmer countries cattle are reared principally as draught animals and for meat.

The great cattle ranching countries of the world in order of head of cattle in each are India, the United States, Russia (at least before the present chaos), the Argentine, Brazil,

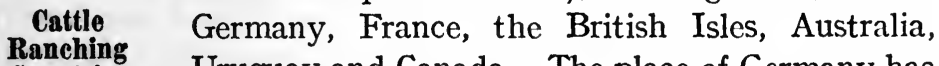
Countries Uruguay and Canada. The place of Germany has probably fallen and France has lost many head of cattle. India retains her cattle for her own use.

Exports of beef and cattle come principally from the United States, the Argentine, and Canada. In numbers of cattle per head of the population the Argentine is easily first, and consequently is in a better position for export than other countries.

Butter is exported in large quantities from Denmark, which has been aptly termed "one huge dairy farm," Holland and New Zealand with rich pasture land, Finland, which has adopted Danish methods, and Australia. Siberia used to export a growing quantity, and France formerly had a surplus.

Cheese for export is made in Canada, Holland, and Switzerland, but several other countries export small quantities of peculiar kinds for which they are noted. Bullock fat is the basis of oleo-margarine.

Another aspect of cattle grazing is the production of horns, hoofs, and skins. These are by-products of cattle ranching and meat production. Large quantities come from India and the Argentine and Brazil. The trade in horns, hoofs and skins includes the products of goats, sheep, etc.

Sheep are the most numerous of the world's domestic animals. They were domesticated in prehistoric times from various closely allied wild species. There are many diverse Sheep breeds, some of which are bred for mutton and others for wool. Very few breeds of sheep are kept for milk. Great Britain has long been one of the chief sheep breeding countries. British breeds are known throughout the 
world, and British wool, until the home demands retained most, was much sought by other nations. Sheep are found in most temperate climates but do not thrive in the tropics. A dry and fairly warm climate suits the wool-bearing breeds such as the merino of the Mediterranean, while a damp climate is more favourable to varieties bred for mutton. In sodden ground disease occurs in sheep. The sheep is essentially an upland animal, which makes sheep grazing an economical cccupation in that it does not employ land suitable for cereal growing. The growth of population in new lands does not encroach on sheep lands to the same exterit as on cattle lands. While cattle must eventually decrease in numbers, sheep will continue to increase, at least in the new lands, as more hardy breeds are discovered. In Europe and the United States numbers seem to be declining. Sheep constitute the chief source of wealth of many remote countries with inhospitable climates such as the Falkland Islands, Fuegia, and Iceland. The ccuntries in which sheep are most numerous are Australia, where they are the principal source of wealth, the Argentine, the United States, Russia including what was until 1917 the empire in Asia, Asia Minor, South Africa, the United Kingdom, Uruguay, and New Zealand. Per head of the population, and so in the best situation for export of mutton, the Falkland Islands, Australia and Uruguay lead.

Wool is derived chiefly from sheep. It varies greatly in different countries owing to variety in breed of sheep and in climatic influcnces. In certain breeds, as merino, all other qualities Wool are subordinated to the production of wool. The nature of the grazing lands affects the quality and value of the wool in cases where it has to be cleaned of extraneous matter. Long-fibred wools are the most valuable. Short-fibred wools find a use in blanket and carpet manufactures.

The chief wool producing countries are Australia, the Argentine, the United States, Russia, New Zealand, Cape Colony, and the United Kingdom. British wool is of high quality and in much demand. About 25 per cent. of the annual yield is still exported despite the home shortage and great imports of wool from other lands. The chief exporting countries are Australia, New Zealand, the Argentine, Cape Colony, and India. The United States not only uses all its own wool but imports large quantitics. In 1914 
the world's production of wool was about 3,000 million lbs. of which Australia produced over 25 per cent. and the United Kingdom about 4 per cent.

The chief manufacturing centres of woollen goods owe their original eminence to local wool and often to the occurrence of water power which, however, is now generally superseded by coal. They include England (Yorkshire), Scotland (the Border country), the United States (New England), Flanders, Italy (Tuscany and Piedmont), and Moravia. Wool is also derived from the camel, goat, and alpaca. These animals yield fine strong fibres. Camels hair comes chiefly from China and Turkestan, goats wool from Asia Minor, Cape Colony, and Kashmir, and alpaca wool, or mohair, from the Andean lands of South America.

Pigs were first domesticated by the Chinese in early times. From crosses between the Chinese pig and the British wild boar the various English breeds of pig took origin. Pigs They have since been introduced into America, where pig-breeding is followed on an extensive scale, especially in the maize region west of the great lakes. About half the maize crop is used to feed pigs which eventually provide hams, bacon, pork, and lard, but principally the last. In Denmark pig rearing, for bacon exports, is largely dependent on the byproduct of the dairy industry. The number of pigs was enormously decreased in the years of war and has not yet recovered. Although in the United States there is a close relation between the growth of maize and the hog industry, the world distribution of pigs is based on economic rather than geographical controls. They are kept in most lands but have no place in Mohammedan countries. In Europe oak and beech forests provide in the acorn a valuable and cheap food for pigs.

The origin of the domestic horse is lost in antiquity. It was an old-world animal, and one species of wild horse is known in

Horses central Asia. The horse was a domestic animal world in the earliest times and was introduced by the Spaniards into America where it had bccome extinct, probably before the age of man. No animal has been of greater service to man or played a more conspicuous part in the growth of civilization. The advent of the railway displaced the horse only in long distance 
travel in densely populated lands. It was not until motor transit became a normal means of transport that the usefulness of the horse began to pass (see p. 31). Many breeds are known, among which the Arab breed is the foundation of the English race-horse and thoroughbred. Ponies are special breeds. The mule, which is a cross between a donkey and a mare, is more sure-footed than the horse, more enduring, and less fastidious about its food.

The horse is used almost entirely for transport, but in parts of Europe horse-flesh is eaten. Hides and hoofs have considerable value for leather, glue, ctc.

In such great plain countries as Russia, the United States, and the Argentine, horses are most numerous. These and other countries export horses.

Donkeys were known in Egypt before the horse and were domesticated from an African species. They are very

Donkeys hardy and docile and are much used in arid countries.

Poultry includes the common fowl, domesticated in earliest times, the duck, goose, and turkey, of which only the last is a new world species. There are many breeds of fowls, some of Poultry which are specialized for egg production. Fowls are now kept in most countries, but chiefly in the vicinity of towns where the demand for poultry and eggs is great. In many lands poultry farming is an important industry which, like cattle and sheep grazing, is an outcome of the industrialization and consequent lack of sufficient food production of other lands. Several European countries, including France and Holland, normally export poultry.

A further aspect of poultry farming is egg production on a large scale for export. Denmark is a great egg exporter, and large quantities used to come from European Russia and western Siberia. Eggs also come from Italy, France, and Ireland, and a poor small kind from. Egypt. 


\section{CHAPTER VIII}

\section{THE DISTRIBUTION OF MINERALS}

THE occurrence of minerals began to have a decisive influence on man's movements and location at a later period than the distribution of plants and animals. Primitive man could make little use of minerals even if they were to be found in easily accessible places on the surface of the ground. Stones such as flints and fragments of bone made the earliest weapons. But at an early stage in civilization the use of the most easily reduced ores was discovered. It was probably a desire for tin which took the Phoenician traders to the British Isles, tin being required to mix with copper obtained in Cyprus in order to make bronze. Iron came into demand at a much later date, for although iron-ores are very abundant they demand some skill in reduction and a great deal of fuel. Agriculture never made any real progress, except on soft alluvial soil, until iron was used for ploughs. Heavy soil cannot be broken up or trees cut down without the help of iron. The rare occurrences of meteoric iron must have proved godsends to primitive people. Greenland Eskimo used to make long journeys to get a supply from some meteors near Cape York. Gold, which invariably occurs in a metallic state, was always sought for ornaments because it is easy to work and does not tarnish. The non-metallic minerals such as coal and petroleum have a short history, but as regards coal one that has modified the distribution of man, influenced his activities, and moulded his outlook both directly and indirectly more than any other factor in the world.

Unlike plants and animals minerals are fixed in their distribution. The mineral content of the surface layers of the earth's crustand this is all that concerns man-is fixed and

Distribution of unalterable. No action of man can increase the
Minerals amount of minerals although his skill is continually leading him to the discovery of fresh deposits. Once the minerals are taken from the earth they cannot be replaced. Mining is therefore a form of exploitation in that it destroys progressively, like hunting, and does not create like agriculture or stock-raising : it has been aptly termed a form of "robber economy." The supply 
of mincrals is not inexhaustible : already deposits have given out in some regions. The distribution of minerals is not dependent on the present climatic conditions, and therefcre leads man into all regions of the globe, from equator to pole. The demand for metallic ores in this age of steel and other metals, and the necessity for fuel with which to supply power for manufactures, results in a widespread and careful survey of all lands including those which are most unpromising for human settlement.

Metallic ores and coal are generally found in the older strata of the earth's crust. These are most frequently exposed or near the surface in regions where folding and faulting Mining Areas have disturbed the strata. In consequence mining is generally pursued in or in the vicinity of mountainous or upland regions. Coastal and river plains, which as a rule are built of newer rocks, are unlikely to contain valuable minerals, or at least none at moderate depths, with the exception of alluvial minerals, which have been worn out of the rocks by river action and washed down the streams from higher ground. Thus valuable mineral deposits tend to be at some distance from the sea and as often as not in regions where transport provides some difficulty. An exception must be made in the case of lands which have undergone extensive depression: in those cases the minerals are often near the sea. The deciding factor in the exploitation of minerals in nearly all cases is transport, and this changes from age to age. This and other problems relating to mining are touched on in Chapter XI.

In the following pages the economic geography of certain of the most important minerals is discussed. Minerals which furnish fuel are treated in Chapter IX.

The ores of iron are numerous and very widely distributed. Few lands are devoid of iron-ores, but the various ores have widely different values. Those of chief commerIron cial value are magnetite, haematite, or specular iron, limonite, brown haematite and sidcrite, and carbonate or spathic ores, including clay ironstone, and blackband ores. The presence of silica, sulphur, phosphorus, or arsenic in iron-ores is regarded as deletericus in the proportion of more than $\cdot 1$ per cent. (in the case of silica 10 per cent.). For certain kinds of steel, however, iron-ore rich in phosphorus is 
used. Iron pyrites, a compound of iron and sulphur, is a widely spread ore, but is of no use for the manufacture of iron. The richest iron-ores, haematites and magnetitcs, have about 65 or 66 per cent. of iron, but ores with over 40 per cent. are well worth working. Lower-grade ores are frequently worked when conditions of fuel, labour, and transport are suitable : they are usually concentrated for export. The neglect of lower-grade ores is due to the abundance of higher-grade ores in sufficient quantity to meet present demands. The lower-grade ores of northern Norway are now made into concentrates with the help of abundant water power.

The iron industry is old and widespread and has been marked by successive improvements in the treatment of ore and the employment of more economical methods. In early days when only comparatively rich ores could be worked on a large scale, charcoal was employed in reduction, but the iron industry is now centred mainly on coalfields (p. 83).

The United States is the greatest iron-producing country in the world, using mainly its own ores, which are found chiefly around Lake Superior in Minnesota, Michigan, and WisIron Produeing Countries consin, and in the southern Appalachian states. The annual output of pig-iron of the United States is more than half the world's annual production. Before the war the production of Germany slightly eclipsed that of Great Britain but by the severance of Luxemburg and the restoration of Lorraine to France, Germany has lost her best iron mines. Great Britain now imports half her iron-ore. Home supplies come from Cumberland, Cleveland, Lincolnshire, Northampton, etc., and imported ore comes from northern Spain via Bilbao and other parts, and Gellivara and Kiruna in Sweden via Narvik. The United States, Germany, and Britain together used to supply three-quarters of the world's total production of pigiron. France and Belgium are considerable producers. Sweden, with vast resources of high-grade ore, is short of fuel except wood and a little coal and so has to export most of the ore. The same applies to Spain. Russia has enormous quantities of good ore in the Urals, the Donetz coalfield and elsewhere, which are badly situated for export but with the help of local coal have given rise to a considerable iron industry. Poland will have considerable resources in iron-ore at the expense of Germany if the Silesian 
plebiscite area votes in favour of the former state. Ukraina produces much ore and pig-iron. China has begun to make use of her immense resources in iron-ore.

In the new countries of the world iron-ore is equally plentiful but comparatively little mined, while no doubt there are many deposits still unrecorded. Cuba, Newfoundland, Queensland, and Brazil are rich in ore. Siberia has many unworked deposits.

The manufacture of steel is a modern outcome of the iron industry. Steel is iron hardened by the addition of carbon and generally

$\begin{array}{cl}\text { Steel } & \text { toughened by the help of manganese, chromium, } \\ \text { nickel, molybdenum, vanadium or tungsten. The }\end{array}$ importance has made their ores valuable. Some of them have also other uses. Manganese-ores come chiefly from the United States, the Gold Coast, Caucasia, and Ukrania; chromiumores from Turkey and New Caledonia ; nickel-ores from Canada, New Caledonia and Norway, and vanadium-ores from Peru and the United States. For molybdenum see p. 67.

Steel-making is the monopoly of the iron-producing centres. The United States used to lead with about 40 per cent. of the world's production, with Germany (25 per cent.) second, and Great Britain (12 per cent.) third. The war however greatly stimulated British production which is now second to that of the United States. Swedish steel is small in amount but has considerable fame. Spanish steel has had a high reputation for several centuries.

Copper is not so widespread in occurrence as iron, but is easier to work in a metallic state. The demand for it, especially as a conducting medium for electric power, is conCopper siderable. Hardened with tin it makes bronze and with zinc it forms brass. The principal sources are native copper and sulphide-ores, known as copper glance and copper pyrites. Ores with less than 2 per cent. of copper pay to work. Countries which yield large quantities of copper-ore are the United States (Michigan, Arizona, Montana, etc.), Mexico, Chile, Japan, Cuba, Canada, Tasmania and Queensland. The Khatanga copperfield, in the Belgian Congo, is growing in importance despite its inaccessibility and the dearth of labour. In the production of metallic copper the United States leads, followed by Japan, Chile, Australia, Spain, Mexico, and 
Canada. The place of Chile is now higher in the scale than some years ago, when its production dropped owing to distance from centres of demand and expensive freights. Mexico has suffered much from revolution, but the Boleo copper mines being in Lower California enjoyed a comparative immunity from the disturbances on the mainland. Japan's high place is of recent acquisition, and Canada is gaining in importance as a producer of copper. Peru also is showing much activity.

Cassitcrite or tin oxide is the only ore of tin which has commercial value, and it has a restricted distribution. Tin is too soft for most purposes where metal is required, Tin and is chiefly used as a coating for thin sheets of iron, known in commerce as tin-plate and used in box-making. Tin and copper together form various alloys, bronze, gun metal, etc. The chief source of tin-ore used to be Cornwall. The Phoenicians obtained ore from the Cornish mines. The discovery of rich deposits in the Malay Peninsula and the Dutch East Indies nearly killed the industry in Cornwall. The greater part of the world's supply of tin, which is derived from alluvial sources, now comes from Malay States, via Penang and Singapore and considerable amounts from the islands of Banka and Billiton. Tin-ore also occurs in Lower Burma and the Siamese Malay States, but want of transport and labour hinders its exportation. Large deposits are being mined in northern Nigeria, at Broken Hill in New South Wales, and other places in castern Australia, but Bolivia now ranks second only to Malaya in output. There is much tin-ore in China, but the home demand takes all the production.

Zinc occurs in zinc blende and also in calamine and smithsonite. These ores are commonly associated with lead, iron pyrites and copper-ores. In early times it was imported from Zine the east in a metallic state, but the ores are now reduced in Europe and the United States. It is much used to coat or galvanize iron in order to prevent rusting. Crude metallic zinc is known as spelter. Zinc oxide, manufactured from metallic zinc, is used in white paint. In Europe zinc-ore is mined chiefly in Silesia, and in Moresnet in Belgium. These two countries and the United States (Missouri and Kansas) produce most of the world's supply. Zinc-ore is also mined in France, Britain, Spain, and Sardinia.

5-(1909) 
The chief ore of lead is galena or lead sulphide. A less important ore is cerussite or carbonate. Silver is generally found in association with galena. Lead is soft and malleable, Lead and has a low melting point. These qualities, together with its power of resisting weathering influence, have brought it into growing demand for pipes, roofing, etc. Pewter and solder are both alloys of lead and tin. Oxides of lead, known as white and red lead, are of importance in the manufacture of paint. The United States, principally Idaho, Missouri, Utah, and Colorado, produce most of the world's supply of lead. Large quantities are also produced in Spain (Cordoba), Germany, Mexico and Australia (Broken Hill, N.S.W.), but lead ores are widespread and several other countries have some production. Britain derives the greater part of her supplies of ore from Australia and her metallic lead from Australia and Spain.

Aluminium combines lightness with great toughness and durability and oxidizes only very slowly. It is also an excellent conductor of electricity, being better in this respect

Aluminium than copper. Compounds of aluminium are of universal distribution and are said to form nearly one-twelfth of the earth's crust. Only a few of the ores are of importance, and even in the case of these the production of the metal is expensive. This explains why aluminium has only recently come into general use in spite of its unique qualities. Various alloys with small proportions of cadmium, calcium, and magnesium are used in aeroplane manufacture. It is mainly produced in electric furnaces from bauxite, with the help of cryolite, another aluminium-ore, which serves only to dissolve the bauxite. Cryolite is found only in south-west Greenland, where it forms nne of the few commodities of trade. Bauxite is found in small deposits in several places in the United States, France, Germany, Italy, Guiana, and Ulster. Production of aluminium is not yet extensive but more than doubled during the war. The chief producing countries are the United States, Switzerland, France, and Scotland. In recent years Italy, Norway, and Canada have come to the fore as producers.

The high temperatures required in the production of aluminium necessitates cheap power. This has tended to locate the works where water-power is abundant, as for example at Niagara Falls 
in America, or the Falls of Foyers and Ballachulish in the Scottish highlands.

Molybdenum occurs in molybdenite, molybdite, and wulfenite. It is used in the manufacture of high-speed steel. The demand for molybdenum is of recent origin and promises Molybdenum to exceed the supply unless, as is not improbable, new deposits of the ores are found. Canada has a considerable amount especially in Ontario and Quebec. In the United States the ores have been found in various localities but principally in Arizona. Norway produces a good deal and there is a growing production in Australia. The ores are also reported from Peru, Mexico and Japan.

Quicksilver or mercury is the only metal in use which maintains a molten state at ordinary temperatures. Its chief ore is cinnabar or mercuric sulphide. Quicksilver readily forms Quicksilver amalgams with many other metals. This quality makes it of value in the extraction of gold and silver from crushed rock, a use which formerly brought it much into demand but has now been largely replaced by other processes. Quicksilver is also used for scientific instruments, in dentistry, and with tin for silvering mirrors. The value of the metal makes it possible to work low-grade ores. Spain (Almaden) used to dominate the world's supply, but New Almaden in California now produces large quantities. Other sources of supply are Croatia (Idria), Italy and Bolivia. China's supplies are used at home.

Platinum is a rare metal. Its ores are of little importance : practically the only source of supply is from alluvial deposits of the native metal. It is an exceedingly hard Platinum metal, very resistant to air, acids and high temperatures, and so is invaluable in scientific work and in jewellery manufacture. Platinum comes almost entirely from the Urals in Russia where the placers are becoming exhausted. It also occurs in parts of Siberia, in Colombia, and in California and Oregon in small quantities. The shortage of supply and growing demands have made platinum more valuable than gold.

Silver is found in a native state and in many ores. Nearly all lead and copper-ores contain some silver, the desilverization of 
which accounts for a large proportion of the world's output of the metal. Silver is used in jewellery and for plating base metals. Hardened with a proportion of copper it is Silver minted for coins, but in most countries silver coins are only tokens, gold being the standard. Recently however the price of silver has risen so high that many silver coins are worth more than their face value. The chief producers of silver are Mexico and the United States, which together yield over two-thirds of the world's supply. In Mexico the mines are on the high plateau and in the United States chiefly in the Rockies and Great Basin region of the west. Other silver producers are Australia (Broken Hill, N.S.W., etc.), Bolivia, Peru, Canada, and Gèrmany. Silver being a relatively high-priced metal, leads to great mining activity where discovered in rich lodes, even if these occur in relatively inaccessible and inhospitable lands (p. 93).

Moreover, silver-ore being relatively easily obtained from the crushed rock, can be profitably mined with the help of unskilled labour. Among the mineral riches of Mexico mining was for many years largely concentrated on silver. The scarch for silver was one of the chief motives in the early Spaniards' penetration of Central America.

Gold occurs only in a native state either in quartz veins, chiefly in older sedimentary rocks and granites, or in placer deposits in alluvial soils, where it is, of course, derived from Gold veins further up the stream. Most gold is obtained from placer deposits. Gold is widely distributed throughout the world, few countries being without any traces of it, but rich deposits of considerable extent are comparatively rare. Alluvial gold is easy to obtain : little skill and no capital are required, and the metal is of such high value that questions of transport, even of food for the miners, are of little moment. Local supplies of labour are unessential. Quartz-crushing on the other hand requires considerable capital and so represents a later phase of gold mining often after the alluvial gold which showed the location of the veins has been exhausted. No region on the face of the globe is too barren or inhospitable to draw gold miners in large numbers when a "strike" is reported, e.g., the heart of eastern Siberia, Klondyke, and Alaska (p. 162). Gold is soft, malleable and ductile and does not tarnish on exposure to air. These qualities, combined 
with its colour and high price, give it a great vogue in jewellery and ornamental work. Its chief use, however, is for a medium of exchange. Gold is hardened by the addition of a little copper for use in coinage. The chief gold-producing countries of the world are the Transvaal, the United States (Colorado, Alaska, California, Nevada, Dakota, Montana, Arizona), Australia (Western Australia, Victoria, Queensland), European Russia, Siberia, Mexico, Rhodesia, and Canada. The world's production greatly increased about the middle of last century with the discovery of the rich gold fields of California and Australia, and towards the end of last century with the development of the South African gold fields. Most of the British imports of gold come from within the British Empire.

In addition to the metallic ores a few non-metallic ores of economic importance may be mentioned. Certain rocks, or agglomerations of various minerals are of value, not for the ores they contain but for building and other purposes.

Graphite, plumbago or blacklead, is a form of native carbon found in igneous rocks and altered limestones. It has a wide use in the manufacture of crucibles, lubricants, polish, Graphite and lead pencils. Artificial graphite can be made in electrical furnaces. Austria is the chief producer of natural graphite and hence the fame of Austrian lead pencils. A great deal also comes from Passau, in Bavaria, but the output of Ceylon is second to that of Austria. Italy, Mexico, the United States, Canada, and Indo-China also produce considerable quantities. The excellent graphite mines at Borrowdale in Cumberland are now practically exhausted.

Sulphur is found in a native state in regions of volcanic activity or is derived from iron pyrites (sulphide). It is used in the manufacture of gunpowder, sulphuric acid and vulSulphur canite. Native sulphur is mined principally in the United States (Texas, Louisiana), Sicily, Japan and Spain. The sulphur deposits of Iceland, at one time of much importance, are now neglected. Transport difficulties have had much to do with the abandonment. Pyrites has a wide distribution. Large quantities are mined in Spain, the United States, Italy, Norway, Canada, France, Portugal, Japan, and Hungary. Copper-ores are frequently associated with the pyrites and copper is produced as a by-product. 
Gypsum is a hydrated sulphate of calcium. Burnt to expel the water it produces plaster of Paris, which is widely used in building. Gypsum is also in demand as a fertilizer, and in Gypsum the manufacture of certain kinds of paper. It occurs among comparatively recent clays and marls. The United States has the greatest output, and is followed by France, Canada, and England (Nottingham, Cumberland, Sussex). There are enormous deposits of pure gypsum in Spit zbergen.

Asbestos is a mineral, valuable on account of its resistance to fire and low power of heat conduction. Its fibrous nature permits of its being woven into a kind of cloth suitable Asbestos for covering steam-pipes, etc. Most asbestos comes from Canada (Quebec). South Africa (Transvaal) is now producing a good deal and has eclipsed Russia (Urals) in output.

Phosphates are in great demand as fertilizers. Phosphate rock of a suitable nature occurs in various parts of the world, but deposits with less than 50 per cent. of phosphate are Phosphates scarcely worth working since they do not pay for the erection of the plant, tramways, etc. The greatest producers are Florida, Tunis, Algeria, France, and Belgium. In recent years certain islands have come to the fore and eclipsed France and Belgium in output. Christmas Island, in the Indian Ocean, and Ocean Island (Gilbert Islands) in the Pacific are inhabited solely for the exploitation of phosphates. The rich Nauru Island, formerly German, was annexed by Britain for the same purpose. Other Pacific islands have attained temporary importance for their phosphates, being deserted on the exhaustion of the beds. Phosphates enter largely into the composition of guano, e.g., Peru, and bone manure from the Argentine and Uruguay.

Under the heading of nitrates may be grouped the natural nitrates of Chile, largely of animal and plant origin, the artificial compounds now manufactured by the fixation Nitrates of atmospheric nitrogen in Germany and Norway, and the saltpetre produced by the promotion of bacterial activity in organic waste. The use of nitrates in munitions of war greatly stimulated the Chilean output in recent years. The greater part of the output used to come to Europe 
but latterly the United States has taken more than half. Artificial production will relieve the demand for Chilean nitrates and eventually decrease their value.

Glass sands and china clays are other mineral

Glass Sands, substances of some importance in stimulating
etc. manufacturing activity.

Precious stones, like silver and gold, draw population, and if valuable enough, stimulate great activity. Diamonds used to be

Precious

Stones found chiefly in India in conglomerate soil, but now practically all the world's supply comes from South Africa. In the Kimberley diamond mines, started in 1870, diamonds are found in an igneous rock. Mines of that nature require much capital and labour. Diamonds are also found in Brazil, New South Wales, and British Guiana. Artificial diamonds of a tiny size can be made, but so far it has been found impossible to make large ones. Other precious stones have comparatively little geographical importance, but it is worth mentioning opals in Queensland, emeralds in Colombia, rubies in Upper Burma and sapphires in Ceylon.

Pearls and mother-of-pearl shell are secretions of calcium carbonate of animal origin. Pearls occur in various species of bivalve and Pearls other molluscs, including mussels in British rivers. The best fisheries are in various tropical seas: excessive exploitation is exhausting some of the banks (see p. 31). 


\section{CHAPTER IX}

\section{SOURCES OF MECHANICAL POWER}

IN the early ages of man human energy was the only source of power available. Under such circumstances manufactures except on a domestic scale were impossible.

Hand labour in manufacturing industry is not extensively employed to-day. The hand-loom weavers of Great Britain are now almost extinct. There are few trades which

Decrease of Hand Labour machinery has not invaded. Perhaps the cobbler of boots and shoes persists longest, but even he is being ousted by boot-repairing machines in which the skill is not in the craftsmanship but in the care of the machine-a type of mechanical style adaptable to almost any machine. Peasant industries are found in some lands which have no other form of power than manual labour available, but they seldom long survive the competition of machine-made goods. That is one aspect of the decay of the Indian jewellers' craft or Moorish brasswork. Thus the European manufacturer in his search for markets kills native crafts and arts of other civilizations. European culture is not an unmixed blessing to all lands.

The early form of assistance which man secured was by the use of animals. The hoe and the hand-plough gave way to the horse or bullock-plough: larger fields and greater

Animal

Power productions were the results. Horse-drawn vehicles replaced pack animals and the earlier wasteful human carricr (see Chapter XIV).

The earliest forms of mechanical power were wind and water. Their use marked a great development in manufacturing activity and had some influence on transport. The wind Wind Power driven ship even with a small spread of canvas was far more efficient and economical in working than the row-boat or the galley manned by slaves. 'Windmills for grinding corn are still common in some countries but are tending to fall into disuse. At best they are slow and cumbrous, and often cannot operate for want of wind at the time when they are most in demand. However, a windmill effects an enormous saving of labour compared with hand-grinding. 
Free exposure to wind located the earliest smelting hearths in the Sheffield district on the top of hills : these were known as Bole hills.

Water power was utilized at an early date in Great Britain for working looms. The streams flow all the year round, being interrupted by neither frost nor drought. Effective

Water Power water power is only obtainable in the upper or hill courses of streams, or less often at a fall in the valley or plain track. This resulted in the location of manufactures in valleys among the hills. The woollen weaving of England used to find a favourable location in the Pennine dales in proximity to both the wool from local sheep and the power to drive the looms. In Scotland the use of water power brought fame to certain textile centres in the Tweed and adjacent valleys, such as Hawick and Galashiels. Similar reasons led to the establishment of the linen industry in the north of Ireland. Water power is still extensively used in flour milling as at Minneapolis, the great wheat centre on the Mississippi river. In timber lands such as Canada, Norway, Sweden and Finland water power operates the saw-mills. The "fall-line" in the rivers of the United States Atlantic coastal plain has stimulated industry in many centres.

The cutlery trade for which Sheffield has been famed for several centuries, owed a great deal in its early days to the abundance of water power in the upland valleys converging

Mill-Dams on the town. In the sixteenth century there were over 100 mill-dams each with its grinding wheel in the vicinity of Sheffield. Their remains are still visible and one or two persist in use.

With the application of electricity to industry water power has revealed a new phase of usefulness which has been enhanced by the discovery of the means of transmitting electric Electricity power by cables for some distance. Lands devoid Power of coalfields but well supplied with water power may in years to come be great centres of industrial activity. It is not improbable that in the course of a century the regions of dense industrial population will no longer be confined to coalfields. The use of electric power in the manufacture of aluminium is mentioned elsewhere (p.66). In Norway, which has no coal, electric 
power derived from waterfalls is extensively used in the manufacture of calcium carbide, artificial nitrogenous manures, and wood pulp. The Lapland railway in Sweden, and at least two short lines in Norway have been electrified. Finland is developing manufactures by the use of water power. It was proposed shortly before the war to supply electric light to Petrograd from the Vuoksi River, in the isthmus of Karelia. Germany employs much water power. In Switzerland and Canada waterfalls also drive machinery which generates electricity for industrial and illuminating purposes. The Chaudière falls light Ottawa and the Niagara falls provide power for aluminium works and factories at Buffalo. Denmark, without coal, short of timber and lacking water power, is ill equipped with any source of mechanical power. A project was lately proposed of importing electricity from Sweden by means of a cable on the floor of the Sound.

If the transport of power on a large scale becomes possible over long distances it will open up a great vista of possibilities and effect great changes in the site values of places. Countries which now import sources of power (coal, oil), may eventually have enough power (electricity) for their own use and a surplus for export.

The French Government, in studying the water power resources of France, recently (1919) published an estimate of the water power available in Europe. Naturally it is merely Europe's Water approximate and subject to correction. The
Power Resources figures signify millions of horse power available: France 8, Norway $7 \frac{1}{2}$, Sweden $6 \frac{3}{4}$, Austria Hungary (before the Peace Treaty) $6 \frac{1}{2}$, Italy $5 \frac{1}{2}$, Spain 5 , Switzerland 3, Germany $1 \frac{1}{2}$, Great Britain $\frac{1}{3}$. It will be noticed that the countries richest in water power are, on the whole, those poorest in coal. The highlands of Scotland are said to have at least 500,000 H.P. available. An estimate of United States water power gives 28,000,000 H.P. of which only about a quarter are developed. In the settled areas of Canada, excluding the far northern regions, there are said to be $8,000,000$ H.P. available of which less than $2,000,000$ are developed (1918). In Newfoundland the fine water power resources of the Grand Falls have for some years been utilized in connection with local timber in extensive paper mills. Iceland, a country of scanty resources, is rich in water power which has been estimated 
at 4,000,000 H.P. Some is already being utilized for electrochemical works, and it has even been suggested that Iceland would be a convenient place for milling the grain which comes from Canada to Europe by the Hudson Bay route.

From early times wood has been employed as fuel and is still used in countries which lack coal. Many of the locomotives of the

Finnish and Swedish railways do their steaming Timber on wood fuel. River steam-boats in little developed or coalless countries use wood. In the days when the Mississippi river was the great highway in North America steamers had to tie up to the bank at frequent intervals to load wood. The wood pile was a feature of that river, as it is of the Congo and other rivers to-day.

Timber can of course be transported, and in this respect it has an advantage over a river as a source of power. On the other hand it is bulky and expensive to carry while the source of supply is continually receding. Since it is not profitable to transport timber for any considerable distance, its use localizes industry near the source of supply.

The use of coal as a source of power on a large scale is comparatively recent. London used coal for domestic purposes as early as the thirteenth century, importing it from Coal Newcastle, but it was early in the eighteenth century before coal or rather coke was used in the smelting of iron-ore on the coalfields. Coal soon became the almost universal source of mechanical power, and industries began to be localized on the coalfields. This led to a complete change in manufacturing activity, commonly referred to as the industrial revolution, so rapid and widespread were its consequences. The change was accompanied by the introduction of machinery on a large scale, the use of which only became possible when considerable power was available.

In the use of coal for heating purposes there is a considerable proportion of waste due principally to incomplete combustion : on an average it amounts to at least 25 per cent. of the coal used. Gasification of the fuel results not only in great economy but in more cleanliness.

In the present age coal is of vital importance to the well-being of most nations, and those nations where territories are best 
endowed with coalfields or whose coalfields are most developed have become the leading and most powerful nations in the world. Industrial supremacy to-day is measured by the coal resources of the country.

Coal of economic value occurs principally in two forms, anthracite and bituminous. Anthracite contains a very high proportion of

Varieties of Coal carbon and is of value especially in cases where great heat is required: most Welsh and Pennsylvania coals are anthracite. Bituminous, including house and steam, coal has less carbon but more coal tar and gas than anthracite. It burns with a bright flame and is often smoky. This kind of coal is used in the manufacture of coal gas and coke. Splint and cannel coal are names applied in Scotland to certain varieties of bituminous coal.

Among bituminous coals a distinction is made into caking and non-caking coals. The former burn freely but cake into clinkers and so give much work in stoking : the latter, as the name implies, do not cake and so are easy to stoke.

A poor form of coal with a relatively low percentage of carbon is that known as lignite or brown coal. In lignite the vegetable matter from which coal is formed has been imperfectly carbonized. The newest coals, geologically speaking, are generally but not always lignite.

Coal is widespread in occurrence but can be worked profitably only under certain conditions. The seams must be of sufficient thickness, relatively free from dirt, and at moderate depths. The deepest coal mine is only some 4,000 feet in depth.

Labour in sufficient quantities must be available and transport facilities must be good, either to export the coal or to import the raw material for the use of factories localized on

Labour in Coalfields the coalfield. The import of food for the mining and manufacturing population is also of great importance. More technical considerations are the nature of the floor and roof, the inclination of the coal strata, the liability to gas and the tendency to flooding. Rising prices of coal due partly to increased demand but chiefly to increased working expenses, have brought new coalfields, such as those of Spitzbergen, into the area of profitable exploitation.

A good deal of waste occurs in coal mining by reason of pillars 
left for support and other causes. This materially reduces the amount of coal likely to be mined in any coalfield : at present the average waste is about 25 per cent. of the coal.

The chief coal-producing countries of the world in 1913 were the United States, Great Britain, and Germany. In that year

Coal-producing these three countries together produced about Countries six-sevenths of the world's estimated total production of nearly $1,500,000,000$ tons. The United States output was over a third, the British nearly a fifth, and the German over a seventh of the world's total. Until 1899 Great Britain had the greatest output; her output is now about $235,000,000$ tons a year. The Sarre coalfield which for the present is lost to Germany, used to provide about 6 per cent., and the lost Silesian coalfield about 23 per cent., of the German coal output. A further serious loss to Germany is the amount of coal that must be handed over annually to the Allies, for various periods of years by way of reparation. This amounts to about $45,000,000$ tons a year, or about one-fifth of the annual pre-war output. Fourth in the world's output in 1913 was Austria-Hungary. Much of the coal-bearing area of this shattered empire is now in Cecho-Slovakia. Austria's chief supplies are now lignite. France was fifth, Russia sixth, and Belgium seventh. No other European countries were important coal producers, and many of them, like Norway, Denmark, and Finland, have no coal resources.

Outside Europe, with the exception of the United States, Japan led in output, her production having risen in thirty years from $1,000,000$ to $24,000,000$ tons. The output of India is slowly increasing but the Indian coalfields are little developed so far. China has enormous resources in coal but her output is little greater than that of Canada. In Australia the principal coalfields are in New South Wales. South America and South Africa are relatively poorly endowed with coal. The geographical isolation of the few coalfields in the southern hemisphere gives them greater importance than the amount of their output might suggest. Thus New South Wales, which normally produces five-sixths of all the Australian coal, exports beyond Australia nearly $3,000,000$ tons a year, which is rather over a quarter of the output of the State. These exports are chiefly to New Zealand, which produces about as much locally, Chile, which produces little but lignite, and Java. 
Other Pacific ports absorb the rest of the export, some curiously enough going to San Francisco and other United States ports. This anomaly of exporting coal to a country having plenty of its own is explained, first by the poorness of California in coal, and secondly by the cheap freights offered by sailing vessels which have arrived in Australia from home ports with general cargoes and proceed to United'States ports to load wheat for Europe. Similar considerations apply to the export of Australian coal to Chile.

Contracts have recently been signed for the import to Sweden of Australian coal. This is the result of low production in Great Britain, and inability of Germany to find coal for export beyond the demands of the Allies mentioned above.

South African coal is mined chiefly in Natal, the Transvaal, and the Orange Free State. Except for the quantity used in bunkering steamships its consumption is mainly in South Africa. There are several undeveloped coalfields in South Africa and Rhodesia. A promising coalfield has recently been discovered in southern Nigeria.

The deficiency of good coal in South America is very marked and militates against its future in manufacturing industry. Colombia and Peru both have considerable deposits but they lie at great elevations at some distance from the coast and are little mined. Chile alone has coal seams at low elevations near the coast, but the coal is relatively poor. Argentine and Brazilian coals are too low-grade to be of much value.

During the war there was a great stimulus to coal mining in most countries, but shortage of labour adversely affected the output and the world's total production was decreased, the United States and Italy almost alone being successful in increasing their production. ficcurate figures are not obtainable for many countries since 1914.

Coal is the only raw material exported from Great Britain in large quantities, if fish is excluded. The export used to be chiefly

Coal

Export to France, Italy, Germany, Sweden, Russia, the bunkers of steamships. Holland, Belgium, and Denmark. In addition large quantities of coal are exported annually in

Of the total British output of coal in 1913 about 38 per cent. was exported, about 30 per cent. used for power production at 
home, and about 32 per cent. used for industrial and domestic purposes. At present less than 10 per cent. of British coal is exported annually.

The possibility of the early exhaustion of coal resources has frequently been discussed. The Royal Commission to inquire into the coal resources of the United Kingdom reported in 1905 that the net amount of coal still in the ground in British coalfields was $100,914,000,000$ tons. At the present rate of consumption this supply should last about 300 years. Since the date of that estimate geological discoveries have considerably extended the area of possible coalfields in Great Britain. The coal reserve of the British Isles, according to a more recent estimate, are over $189,000,000,000$ tons or about one-fiftieth of those of the entire world.

The Coal Conservation Committee of the Ministry of Reconstruction in 1918 laid stress on the necessity for more economical use of coal by the conversion of coal into electrical

Economy in use of coal power. This would increase the power obtained from the coal and so save energy and leave more coal for export, an important aspect of national prosperity. By large power stations under national control it is asserted that onethird of our home consumption of coal could be saved and greatly increased power obtained.

Petroleum is a natural oil of wide occurrence. The oil or its derivatives are used as lubricants, illuminants, or fuel. Petrol is a volatile distillate of petroleum which is much

Petroleum used for motor engines. Kerosene or American paraffin oil is a light distillate used for illuminating purposes. British paraffin, although essentially of the same nature, is obtained by the distillation of bituminous shales. The product is solid at ordinary temperatures and is used for candle making. The heavier oils are mostly of use as lubricants. Naptha, benzine, and vaseline are other products of petroleum. The growing use of mineral oil as a source of power has resulted in an enormous increase of output subsequent to the discovery and exploitation of new oil fields.

Eagerness to secure the oilfields of Persia and Mesopotamia is at the root of British policy in the Middle East.

Mineral oils are rapidly displacing vegetable oils for all purposes. 
In few areas where natural oil wells occur is the petroleum utilized as fuel on the spot : it is generally exported to other centres more advantageously placed for manufacturing. Oil can easily be transported by pipe lines : in some cases it is carried hundreds of miles to centres of demand or sea ports. As a fuel the advantages oil has in contrast to coal are its greater calorific power, its more complete combustion, and its greater convenience in storing. On the other hand it affords some danger from explosion.

The chief petroleum fields of the world are in the United States, in Pennsylvania, Ohio, Kansas, Oklahoma, California, Texas, Illinois, and other states. From Illinois and Chiof Kansas pipe lines lead to Atlantic and Gulf of
Petroleum

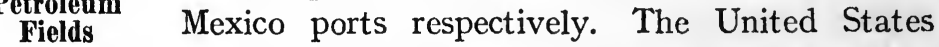
mineral oil production which in 1860 was only about 400,000 barrels, was $377,700,000$ barrels $^{1}$ in 1919 which was nearly 70 per cent. of the world's output.

Twenty years ago the Russian output from the Caucasian oil field somewhat exceeded that of the United States. In 1919 it was only $34,000,000$ barrels, or only one-sixteenth of the world's output, in contrast to nearly one-half at the former date. The oil is carried in a pipe line from Baku to Batum on the Black Sea. Next in importance to the United States is Mexico with an output in 1919 of 87,000,000 barrels. The exploitation of the Mexican oilfields began only about twenty years ago. Unsettled political conditions and lack of tank steamers alone prevent a much greater output. An economical method of loading oil is being employed at Tuxpam. The ends of the pipe line are carried out to the steamer's anchorage off the coast where loading proceeds, thus doing away with the necessity of harbour construction on a harbourless coast.

The Dutch East Indies, Sumatra, and Java produced 15,780,000 barrels and Burma 8,500,000 barrels in 1919. Other countries which helped to make up the world's total output of $557,000,000$ barrels were Austrian Galicia (now in Poland) with 6,200,000 barrels, Japan and Formosa with 2,120,000, Peru with 2,500,000, Trinidad with 2,780,000, Egypt with 2,500,000, and Persia with $8,300,000$. The Rumanian output, which in pre-war days was over

${ }^{1}$ A barrel holds approximately 42 gallons. 
$13,000,000$ barrels a year, fell to about $6,000,000$ barrels owing to the partial destruction of the wells.

Western Europe has few oil wells, and reports of oil in England have failed to materialize on a scale of any importance. Some progress is being made with the development of the new oil fields in Persia.

Natural gas is the lightest product of petroleum. In many oilfields it is wasted but in Pennsylvania, Ohio and adjacent states the natural gas is conveyed in pipes to Pittsburg,

Natural Gas Toledo, Cleveland, and other industrial centres, fuel. where it is of considerable importance as cheap

Alcohol promises to hold a place of growing importance among sources of power. It is used as a substitute for petrol on account of its low price. The future of alcohol as a fuel Alcohol lies in the fact that it can be produced from an endless number of vegetable materials. The sources of its supply, being dependent on growth, are inexhaustible.

Man has failed so far to utilize several sources of power. On all ocean coasts there is a tidal rise and fall of the waters several feet twice a day. An even greater source of power

Other sources of power is the energy of solar radiation in such clear, cloudless regions as the Sahara. The discovery of means to utilize effectively this energy might make the borders of hot deserts the great manufacturing regions of the world. 


\section{CHAPTER $\mathrm{X}$}

\section{LOCATION OF MANUFACTURES}

THE collection and production generally of raw material leads to manufacturing industry, sometimes near the place of origin of the material and sometimes at a distance. It is important to trace the geographical controls which influence the localization of manufactures. A knowledge of the principles involved is of great value in deciding the locality in which a new industry is likely to succeed. These results are reached by an analysis of the factors which have promoted success in the manufactures now existent and in those which from time to time have failed.

Of the various factors which decide the locality of successful manufacturing ventures the majority are geographical, while those which are more purely economic are so closely

Geographical interwoven with geographical considerations that they cannot well be ignored in this study of the subject. The different factors may be mentioned separately, but their interaction must be continually borne in mind.

Every manufacture requires raw material which sometimes occurs or is produced in the vicinity, but more frequently is brought from a distance. Manufactured articles for which Material ${ }^{\text {aining }}$ the requisite raw material cannot easily be carried must be manufactured on the spot. The canning of milk, fish and meat, and the preparation of fish and whale manure must be carried on in the centres of production or convenient seaports near the fishing grounds. Water as raw material is used in such manufactures as brewing and distilling, but good water is of such widespread occurrence that other factors usually decide the localization of these industries. It is said, however, that the waters of the Trent have peculiar qualities that favour brewing at Burton. In the occupation of dyeing and cleaning of fabrics and fibres pure water favours a site near the upland courses of rivers above all other towns, such as Perth or Bradford. In papermaking abundant pure water is also of great importance. Paper mills are on the up-river outskirts of great towns. A bulky raw material like granite which in manufacture undergoes no change 
except in dressing, leads to an industry where it occurs, provided always that transport and labour are available. Hence the industry of Aberdeen in granite setts and monuments.

As a rule, however, a consideration of more weight than proximity to the raw material is the occurrence of fuel or other sources of power. This applies especially to manufactures using metallic ores or raw metals, but is seen also in textile spinning. Wool from the uplands led to weaving among valley populations of Great Britain at an early date, while a later use of water power in many cases did not displace the industry. Later, however, it concentrated on the Yorkshire coalfield where the best source of power was available and skilled labour was to be found.

The discovery of the method of using coke in place of charcoal in the smelting of iron-ores moved the iron industry from the woodlands of England to the coalfields. The proximity of coal and iron-ore transferred the industry from such districts as the Wealden forest to places like Sheffield and Leeds. The local supplies of ore are now quite inadequate for the demands of the founderies, but for other reasons, considered later, the industry grows on imported ores.

The tin mines of Cornwall, now practically abandoned, originated the tinplate industry of South Wales which thrives at present on imported tin.

The tendency of manufacturing is to carry raw materials to the fuel and hence the congestion of industrial centres on coalfields. Those industries which require comparatively Avoiding little fuel can be economically pursued at some
Congestion distance from the coalfield where other advantageous factors come into play. In this way London has many varied industries despite its considerable distance from coal.

It has already been explained that water power is tending to rival coal as a source of power and so effect a redistribution of manufacturing activity (Chapter IX). The growing manufacture of wood pulp and paper on the site of the raw material is an illustration of this tendency.

When timber was the only material from which ships were built, the occupation of ship-building was pursued in ports near to the best growing timber. Time was when Whitby had a name for its ships owing to the oaks of the Esk valley and Cleveland hills. 
Scandinavian countries, with their timber supplies, still build wooden vessels and are indeed the only lands where such ships can now be satisfactorily built.

The flour mills of Minneapolis are a product of the wheat belt of North America as much as the windmills of England were a response to local production of corn.

Labour is, of course, an important consideration, especially as regards skilled labour. The establishment of manufacturing industries always tends to draw labour from Labour agricultural pursuits partly owing to the higher wages in factories than on the land, but partly owing to the natural gregarious tendency of the human species. A more important geographical bearing of the labour question is the growth of specialized skill and traditional efficiency in certain districts. This helps to root an industry in its locality even when the original controls have ceased to operate and promotes the introduction of allied industries. Skill in labour causes towns to grow but not to originate. It explains the so-called geographical inertia in virtue of which the localization of an industry is often explicable only by a knowledge of the history of the district.

Cotton came to Lancashire largely because of the skill of the textile workers, long engaged in woollen manufactures. So also jute came to the flax-spinning districts of eastern Scotland.

Sheffield has long since outgrown its local ore and local production of iron but retains its eminence as a steel centre, even though the raw material is now brought from near and far.

So important is technical skill that new industries frequently have to rely in the beginning on imported skilled labour which can be dispensed with only when local operatives have learnt the trade.

Cheap land may localize a new industry requiring much space at a distance from the source of fuel. This consideration weighs

\section{Advantages of Cheap Land}

particularly in the case of those manufactures which demand comparatively little fuel in proportion to the value of their finished articles. Railway companies being advantageously placed with regard to the transport of coal generally find it economical to locate their locomotive and carriage works at some place on the system where there is no industrial congestion. The North-Eastern works at 
York, the Midland at Derby, and the Brighton and South Coast at Brighton are examples.

Facilities for reaching markets are very important to the success of any manufacturing industry and scarcely less important, although on occasions outweighed by other factors, is Marketing accessibility to raw material or rather to seaports at which it arrives. The bulkier a commodity is in reference to its value the more important does this consideration become. Bulky cargoes require to be carried by the cheapest transport to their areas of use (p. 131). The skill in dealing with local granite has led to the import of Baltic granites, gabbros, and other igneous rocks to Aberdeen, where the material is cut and fashioned practically at the harbour side. The manufacturers of Sheffield, in order to get economical transport for their bulky manufactures, contemplate a ship canal to the Humber. In the case of Sheffield it is the problem of transport also which localizes the heaviest manufactures in the Don valley, leaving lighter work to higher ground. Newcastle and Fifeshire coal have always been better placed for export than coal from most other fields in Great Britain.

In this connection a factor of the greatest economic importance is that of railway rates. Cheap railway rates are necessary in order that agricultural produce from as wide an arca

Railway Rates as possible may reach large centres of population at reasonable prices. Cheap and bulky vegetables still reach Covent Garden by slow but economical farm wagons. Any increase in railway rates after industries are once established falls most heavily on manufactures which require long rail transit to ports or centres of demand. It tends to kill the remoter to the advantage of the nearer manufactures.

The importance of skill in giving geographical momentum has been noted. Somewhat similar results are due to long established transport arrangements and control of markets. The construction of the Manchester Ship Canal did not rob Liverpool of its oversea trade at the expense of Manchester. It had in fact no adverse effect on the trade of Liverpool. Similarly the creation of the port of La Plata did not kill Buenos Aires even when the latter place had quite inadequate harbour facilities. Although the jute mills are growing in number in Calcutta, Dundee is not unduly 
apprehensive of the loss of its own jute trade. Established markets, combined with skill of workers, have securely rooted the indus!ry in Scotland.

Climatic factors in the establishment of manufactures are touched on in Chapter II.

Reasons of a geographical nature are found to be operative in the localization of most manufactures. But some industries seem to originate and flourish irrespective of geographical influence. There appears to be no particular geographical reason for the manufacture of confectionery at York or rubber goods at Edinburgh. The occurrence in all agricultural towns of breweries is the outcome of local demands. In the same way agricultural wagons, carts, and implements generally are widely made in market centres even though the requisite timber and metal have to be imported. 


\section{CHAPTER XI}

THE DISTRIBUTION OF POPULATION

MANKIND is widespread throughout the earth : the tide of human life has swept up to the borders of the ice deserts of the poles and the high mountain peaks of the world. Even the most unpromising lands have their human inhabitants. The Eskimo find a home in the barren Arctic lands and the Nilotic negroes live in the dismal swamps of the Bahr-el-Ghazal: in the heights of the Andes, in southern Peru, there are dwellers at an elevation so great that the atmospheric pressure is reduced to half the normal which we experience : the arid deserts of Arizona, among the most uninviting spots on the earth's surface, are inhabited by miserable nomadic Indians. Human life, however, is very unevenly distributed : some regions retard the growth of population and others foster it. Some lands with great potentialities for population are sparsely inhabited while others of apparently less attractiveness are densely populated. In a general way it is true that most of the earth's human inhabitants dwell in the lowland regions of the continents, and that the zone of dense population lies in temperate regions of the northern hemisphere.

Variations in density of population depend on various factors among which the most important is obviously the productiveness of the land. Food being the elemental want of

Question

of Food

Supply man, there is no more fundamental control of growth of population than food supply. A rich agricultural land produces more grain per acre than a poor one, and this allows more people to live on a given area. Similarly a pastoral land fit for cattle supports a denser population than one fit only for the grazing of goats because cattle yield more milk and meat than an equal number of goats. An entirely unproductive land supporting neither animals nor vegetation, affords no homefor man. An expedition to theinterior of Greenland has to carry all its food since the ice plateau yields none. The hot deserts of the world, with their scanty vegetation, support little animal life and a very sparse human population. Luxuriance of vegetation does not necessarily mean great density of human life. Tropical 
forests which express the most luxuriant plant growth in the world are thinly populated, and the coniferous forests of northern Canada and eastern Siberia support very few inhabitants. This is an illustration of the law that food supply determines density of population. Man's chief occupation wherever he is found is to acquire food for himself and his family.

In the tropical forest trees afford some edible fruit, while in the more open spaces along the river banks small patches of banana, manioc, and other tropical plants can be grown, but cereal crops cannot be cultivated. The absence of grassland precludes domestic flocks. The surest if not the only way to procure food is by hunting wild animals and by fishing in the rivers. Game animals are neither numerous nor easy to hunt in the forests, and their numbers and distribution decide the extent of the population. Whether in the African jungle or the Scottish deer forest, hunters must wander singly or in small parties. For the same reasons there is a sparsity of population along the Arctic shores where the Eskimo wander in search of seals and fish in the sea, bears on the ice, and reindeer on the land.

Fishermen are but hunters in the sea : their wanderings are by water instead of land. Fishing communities cluster along the

$\begin{array}{cl}\text { Fishing } & \text { coasts but their number depends on the supply of } \\ \text { Communities } & \begin{array}{l}\text { fish in the sea and the skill of the fisherman in } \\ \text { capturing it. The primitive Patagonian with his }\end{array}\end{array}$ frail boat and poor weapons cannot get from the sea a yield equal to that of the better equipped Malay, who in his turn is far outclassed by the Scottish fishermen with their steam-power and huge trawl nets. Probably in the early days of man on the globe the only communities which reached any density of population were those of fisherfolk on the coasts of shallow temperate seas where fish are abundant.

Under other conditions of environment the surest way of acquiring a safe food supply is by the domestication of animals and the tending of flocks. This mode of life lacks the precariousEnsuring
Food Supply ness of hunting, ensures from want, and permits of a higher density of population and greater prosperity. In the pastoral activity everything depends on the nature of the pasture. In poor steppe land the flocks wandering from place to place in search of nutriment, force their 
owners to become as nomadic as hunters. The pastoral tribes of the Old Testament, or in more modern times the cowboys of America or Australia, illustrate this nomadic life. In richer grassland the flocks not only prosper better, and cattle can replace sheep and goats, but there is less call for nomadism. The population is thicker and more sedentary, as in the cattle lands of eastern Australia or nearer home in Ireland or the plains of Cheshire and Yorkshire.

Grassland under suitable conditions of moisture and temperature admits of an occupation still more secure and reliable, namely, agriculture. Cereal crops are grasses with varying climatic requirements. Root crops are less exigent in their demands but not equally nourishing. Wherever agriculture in one form or another is profitable, it has generally become the principal occupation of the land. That agriculture induces a sedentary life is obvious. The farmer is rooted to his fields and cannot leave them without imperilling his livelihood.

The fertility of the soil, the nature of the crop, and its suitability for the climatic conditions control the density of population. The

\section{Fixity of Population} earliest sites of intensive agriculture were river valleys, like those of the Euphrates, Tigris, Nile, Ganges, Yangste, and Hoang. Rich alluvial soils abundantly watered by natural rainfall or by flood and irrigation, with high summer temperatures and long days of bright sunshine, make ideal conditions for cultivation. No other occupation gives as certain a livelihood. The more labour and care that is put into the fields the more abundant the return, and in like measure is the fixity of the population established and its prosperity assured. Leisure from the daily quest for food results in the development of art, education and culture expressed in literature, architecture, decorative art, household furnishings, and personal adornment. In short, it is agriculture that gives the greatest scope for progress and the growth of civilization. It is the occupation with the highest potentialities and has formed the basis of all the progressive civilizations of the world from the earliest times.

Agriculture leads to a denser population than pasturage or hunting. Wheat with its one crop cannot support as many people as rice can with its possible three crops a year. The yield of crop can generally be increased by careful manuring, but some lands are 
so rich as not to demand this attention. For want of adequate manure most lands become exhausted or impoverished, and must be allowed to lie fallow or bear a rotation of crops. In newlysettled countries, where land is cheap and manure not easily obtainable, it is more economical to bring new land under cultivation than to manure the ground which has borne crops. These methods in time give way to intensive agriculture and correlated density of population.

China can support her huge population, which is mainly agricultural, by the careful renovation of her fields in which every scrap of manure available is utilizcd. In many cases the same fields bear wheat or barley at one scason, and millet, sweet potatoes or soya beans at another. The application of scientific discoveries often increases the agricultural output of a region, and in other cases extends the possible area of tillage. Espccially important is the value of science in lands that seem to have reached the limit of their production and consequently of population.

Certain irrigation gives greater security to the inhabitants of an agricultural land than uncertain natural rainfall. Irrigation on a large scale has been carried out in many of the Irrigation dry sunny lands of sub-tropical regions, with the result that these lands are regions of dense population. Irrigation in the valley of the middle and lower Nile, which dates from very early times, has rendered great areas habitable. Recent improvement to the barrage below Cairo, and the construction of the Asyut and Aswan dams by saving the surplus water of the Nile floods and regulating its flow in the dry season, has immensely increased the cultivable area of Egypt. The irrigation works in Mesopotamia, which lapsed under Turkish indifference, are to be restored with the help of a great barrage on the Euphrates at Hindieh. There is sufficient water available to irrigate several million acres of good soil. In New South Wales the great irrigation works depending on the Burrinjuik reservoir on the Murrumbidgee will permit of the settlement of 400 square miles of hitherto useless land. In India, especially those parts which are liable to a deficiency of rainfall in a weak monsoon, agriculture is founded on irrigation. About 80 per cent. of the cultivable area of Sind is irrigated, and in the whole of British India there are over 60,000 miles of irrigation canals. The danger 
of famine is thus greatly reduced. In the United States much irrigation has been successfully accomplished and over 20,000,000 acres of arid land have been made productive.

In some lands water can be obtained in large quantities by sinking wells, but this type of irrigation has only local results. New oases have been created in the Algerian Sahara and led to a settled if small population. In the so-called artesian basin of eastern central Australia hundreds of wells have been sunk. They are mainly of value for the watering of stock.

Other applications of science to agriculture may be mentioned. They have a direct bearing on the potentiality for population of the land. In discovering how to fix the free Application of nitrogen of the air for the nutriment of plants
Seience to Agriculture the chemist is making the farmer independent of the import of natural nitrates. The biolcgist by a study of variations and the facts of inheritance, is able to select stocks for particular conditions of climate and soil. Entomology has contributed to agriculture by a knowledge of insect pests, and to stock-raising by discoveries relating to the insect carriers of diseases (p. 26). The engineer has brought new land under crops by constructing railways and building ports, and the metcorolcgist by his study of weather and accuracy in forecast has made agriculture less precarious.

Increase in crop production is not necessarily associated with local increase in population. The amalgamation of many small into a few large farms results in an actual decrease in population, while the introduction of agricultural machinery leads to a decrease in the amount of labour required. But an increased produce is available for export from the locality and encourages an incrcase in population in some other place.

It must always be remembered in studying the present distribution of population on the globe that few lands are full : almost all could support increased numbers of people by

Utilization

of Resources necessary adequate utilization of their resources.

Many agricultural lands would yield more by improved methods of farming : forests could give way to arable land as they have done in most parts of western Europe : dry lands and even deserts might be irrigated as far as water is available. The tendency is towards better utilization of 
the land, to make two blades grow where one grew before, even if there are occasional relapses in the process when arable land reverts to pasture or goes out of use altogether.

While intensive agriculture supports a dense population fairly uniformly distributed, the quest for minerals and their utilization result in a denser but irregularly distributed population. An agricultural population is limited in number by the food the region produces. There is no incentive to allow further increase by the importation of food. A mining or manufacturing community produces little or no food. Importing practically all its supplies from a greater or shorter distance, it is divorced from local food production and so the limits of its growth are dependent only on its facilities for importing.

Industrial activity on a large or exclusive scale is a secondary occupation which is dependent, as far as food goes, on a surpius $\begin{array}{cl}\text { Spread of } & \text { production in some other land. The spread of } \\ \text { Industrialization } & \text { industrialization means more nations competing } \\ \text { for food from the new lands of the world. The }\end{array}$ situation becomes more complex as these new lands in their turn become fuller of population and have less surplus food to export. In their own time many of them will become partly industrialized; witness the United States or to a less degree India. The peasant working at a lower wage feeds the industrial worker who, with a higher wage, has a better standard of living. Ultimately the peasant pays the price of manufacturing industry.

A further illustration of the independence of mining activity of local food production is its possible location in barren lands or

Mining deserts. In fact the only controls are the occurTowns rence of minerals in quantity or value sufficient to allow transport to centres of demand. To the Kalgoorlie goldfield of Western Australia water has to be brought in a pipe $\mathbf{3 5 0}$ miles long. The towns of the Yukon valley in Canada and Alaska, are virtually cut off from the world for many months every year by the freezing of the Yukon River. In Spitzbergen coal mining continues through the long polar night when the only link with the outside world is by wireless telegraphy. The location of mining towns is further discussed in Chapter XVI.

A population engaged in alluvial mining is scattered along the lower slopes of the valley, but ore miners are generally concentrated 
near the places where the ore outcrops or is most easily reached by shafts. The rapid exhaustion of alluvial gold encourages a seminomadic population. Report of gold leads to an instantaneous rush of people, experienced and inexperienced, whatever the difficulties and dangers of the journey may be. They come with little equipment and bivouac on the goldfields, only to pass away as quickly when the yield of metal decreases.

The deep mining of metallic ores and other minerals results in a closely packed population, whose permanency is assured provided the supply of mineral persists. On mining being followed by manufacturing a further degree of density of population ensues. Since minerals occur chiefly in old rocks, which are more likely to be exposed in hilly districts than in plains, mining and allied manufactures are normally associated with the upland parts of a country. Provided the mining country is fertile a certain amount of agricultural activity persists and may even be stimulated by the demands of the towns. Market gardening and poultry farming are instances of this tendency, but the agricultural population is a small percentage of the whole. In Lancashire the population reaches a density of over 2,500 per square mile and in the West Riding of Yorkshire it is over 1,100 per square mile. The figure in Belgium used to be nearly 700 in spite of large areas of sparsely populated uplands. France with relatively little industry compared with its intensive cultivation, had a density of 190 per square mile. In Russia, which is an agricultural country with much waste land, the corresponding figure is only 50 .

It is impossible to foresee the degree of increase of industrial populations: none has yet reached its limits, and vast mineral resources remain untouched while others are only

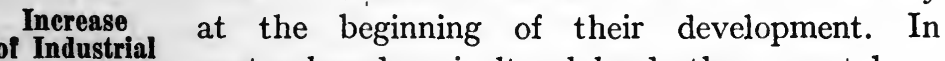
Populations pastoral and agricultural lands there must be a limit to density even when all the possible agricultural improvements are foreseen. The prospects of increasing the possible resources of lands have already been noted. Of more immediate importance is the extent to which agricultural lands are full according to present resources. China must be approaching her limits of population unless she can import food on a large scale. Japan is feeling the stress of pressure due largely to her growing industrialization. In both countries the best land is so 
intensely cultivated that agriculture merits the name of horticulture. India and Java are full to overflowing.

Canada and the United States have still room for millions apart from land that might be reclaimed from swamp or desert. Even Alaska is not without possibilities. Enormous areas in Siberia are waiting for people who will come only with improved communications and a stable government. Siberia could probably support another $80,000,000$ inhabitants. Manchuria and Korea have room for several millions. The temperate grasslands of South America round the Plata estuary and in Patagonia, have room for a huge population. South Africa, from the Cape to Rhodesia, has vast areas of vacant land of which a great deal is of value. East Africa, at an elevation of $5,000 \mathrm{ft}$. or over, is a temperate land with abundant space for human population. About 40 per cent. of Australia, or about $1,250,000$ square miles, is suitable for temperate agriculture, but the whole continent has a population of only about 5,000,000. The potential population of tropical Australia has been estimated to be nearly $1,500,000$ as against an actual total of 170,000 to-day. New Zealand has room for a much larger population than it has.

The population in most tropical lands falls far short of what they could easily support. The problems connected with the development of tropical lands are referred to in Chapter XII. 


\section{CHAPTER XII}

\section{LABOUR}

A MOsт important consideration arising out of the distribution of population is the degree of productiveness of various peoples. On this depends to a great extent the course of commerce, and also the development of lands.

The expansive civilizations of the world all grew in temperate lands from which the people passed to the economic and political conquest of other and less progressive people.

Native In the temperate lands in both hemispheres this
Population led to colonization by the people of Europe, but in tropical lands where conditions are averse to settlement and colonization by temperate people, it caused exploitation of the natives in some form or other. For in tropical lands, for reasons that are explained elsewhere, the natives were discovered by the Europeans in a primitive non-productive state, and as a rule in small numbers. As a producer above his meagre daily need, the average inhabitant of the tropics is of little account : he produces no surplus for trade. The white man insists on tropical lands yielding their riches. As a result a serious labour problem has arisen in those lands of lowly civilization or none at all, which are unsuited for European labour and settlement, but at the same time are of high potential value for food and industrial crops or for mining. The earliest answer to this labour problem was the growth of African slave trade in response to the demands of Europeans in America. This was not the origin of the trade in African negroes, which had existed long before America was discovered. The earliest importation of African negroes into Europe was the outcome of the wealth and urbanization of the Roman people. But the trans-ocean trade in slaves originated in the European settlement and exploitation of the Americas. Slavery in Africa, or even in Mediterranean Europe, was a kindly bondage compared with what the black man had to face in America and on the way thither. The Spaniards found in the West Indian islands a sparse population of semi-nomadic forest people little suited and less willing for arduous labour in the fields and mines. The white men themselves were unable to do the 
work and so began the importation of negroes from Africa (see pp. 149-152).

The African negro has great physical strength coupled with a docile, cheerful disposition, a nature singularly adapted for servitude. Whatever may be said against the cruelty Negro Labour involved in methods of transport and the practice of slavery there is little doubt that the West Indies, the southern plains of the Mississippi, and other parts of tropical and subtropical America owe a great deal to this negro labour. Without its help those lands could never have reached their present state of economic development. The opposition of the northern states to slavery and the insistence of the southern states on its continuance led to the American civil war of 1861-65. The division of opinion was largely the outcome of different economic needs, the north being suitable and the south unsuitable for white labour.

A growing tenderness of conscience eventually led to the abolition of the trade in slaves. At first the export from Africa was prohibited and later servitude in America was ended. Abolition The slaves remained as free wage-earning labourers Trading and their rapid rate of increase has led to an abundance of negro labour in the southern states of America and the West Indies in sugar, cotton, tobacco, and other plantations. The bulk of the negroes remain in the former slave states and the excess moves westward. The boundary between subtropical and temperate climates which approximates to the parallel of lat. $38^{\circ} \mathrm{N}$. across the United States is, broadly speaking, the northern boundary of the black labourers.

While the labour problem in the warmer United States and West Indies found its solution in freed slaves, the economic demand for

Tropical labour in other parts of the tropics remained. Natives The demand for tropical products had increased : tea, coffee, spices, and other things that once had been regarded as luxuries were now looked on as necessities. Something had to be done to make the lands of the tropics yield more than the casual native produced. If it was wrong to force people to work they must nevertheless be induced to do so, and the only way to encompass that end was by holding out the prospect of gain. But a tropical native has few wants, and unless his wants can be 
increased gain is to him no allurement. Clothes which he does not need, and trinkets and mirrors that appeal to his vanity may be enticements, but firearms and drink are the two things that stimulate him most and do him most harm. . With his low standard of civilization a tropical native can with difficulty be induced to do more than a modicum of work. Until their wants increased, why should they work? An instance occurred in a recent report on West Africa. Owing to a rise in the price of rubber the native collecter got as much money; or goods, for a less quantity. The result was that he brought the trader less rubber than before : until he acquired new wants he saw no object in harder work.

As a rule the method of inducing the indigenous native to work for wages has met with little success unless it has degenerated into slavery. The abuses of the system in the rubber regions of the Congo and Peru were lately exposed. The natives nominally received payment for the amount of rubber they brought in from the forest, but in actual practice their taskmaster insisted on a certain amount, and if this were not forthcoming, punished and maltreated the native. In the Congo and in Putumayo the system led to barbarities far in excess of anything that took place in the days of slavery, and it is not many years since the methods of recruiting and employment of negro labour in some of the cacao plantations of tropical Africa were virtually those of the slaver.

A system of forced labour primarily intended for public works is found in many countries, and is only a logical development of the idea underlying military conscription. In Forced Egypt, in the sixties and seventies of last century, it amounted to enslavement on a large scale. In the former German islands in the Pacific, however, the practice worked well and fairly.

The alternative to forcing local population to work is the importation from afar of willing labourers, who are suited for the conditions of climate. That is to say, the labourers must be

Imported Labour

brought from another tropical or subtropical land and one by preference in which some form or other of agriculture is the predominant occupation. China and India, with their vast overflowing populations, afford the best recruiting grounds for indentured labour. Coolies from these lands working for a certain wage for a term of years are found in 
many tropical lands, excluding of course those with a population of freed negro slaves and their descendants. Natives of India under these conditions are found in parts of Burma, the Straits Settlements, Mauritius, Natal, some of the West Indian Islands, Fiji, and in British Guiana, while Chinese are employed in the Malay States, the Straits Settlements and elsewhere, and Japanese in the Hawaiian Islands. Brazil having an inadequacy of labour in the freed slaves tried some years ago the introduction of Japanese coolies to southern Brazil. The experiment was not very promising at first but later attempts appear to have been more successful. Some 18,000 Japanese contract labourers arrive annually. It must not be forgotten that the southern provinces of Brazil have proved fit for European settlers and so do not require Asiatics to further their development. But the few tropical lands that have no industrious alien labour remain at a low level of economic development, New Guinea for instance, the Philippines in Spanish days, and many parts of tropical America. There is far more difficulty in developing the tin deposits of Lower Burma than those in adjoining Siamese territory because of the difficulty the British Government puts in the way of the introduction of Chinese labour.

In theory the practice of imported labour works well, but it is liable to many abuses. Imported coolies working for some profit to themselves no doubt do more work than slaves

Abuses of Imported Labour with no incentive to do their best when the overseer's back was turned. There have been many cases of indentured labour, although actually paid, degenerating into slavery. Most notorious is the case of the South Sea island labour in the sugar plantations of Queensland. These " Kanakas," inhabitants of the islands of the south-western Pacific, were nominally willing recruits but in many cases were actually kidnapped by the traders. "Blackbirding" became a lucrative occupation in South Pacific islands until it was put an end to in 1890 by the Queensland Government prohibiting the importation of further labour from the South Sea islands.

But just as slavery helped to develop certain lands, so has indentured labour done likewise, even if the distinction between the direction of a lower race and their mere exploitation is one so fine that it tends to disappear in a fog of words. 
The importation of alien labour not infrequently gives rise to serious economic problems in the mingling of diverse stocks. These difficulties must not be overlooked.

Alien Labour But if indentured labour is to go the way of slavery something must take its place, for the economic problem of the development of the tropics is always with us and always increasing in intensity. Perhaps in more cases than are generally admitted the indigenous native may be induced to work. Many authorities believe that the negro, for adequate return and generous treatment, can be induced to supply all the labour required in his home lands. He has done no less in tropical America and the southern United States. The negro's social organization should be studied and preserved, and he should be led to greater effort along his own lines. To force him to accept an alien organization and discipline is not merely a blunder but a policy that in the light of experience is doomed to failure.

Some regions may prove less unsuited for European labour than was formerly supposed. The opposition to Chinese labour in the South African mines led to its withdrawal and Emigration its place has been taken by Kaffir labour. Possibly Settlement the conditions of climate will admit white labour being utilized when it is obtainable. Another way in which the labour problem in the tropics may be settled is by the free immigration and settlement of people from crowded tropical and subtropical lands, that is to say, principally from China but from India and Japan also.

In -Australia this problem is being faced already. The abolition of "Kanaka" labour in tropical Queensland led to an economic difficulty which was met only by its temporary A "White reintroduction. But this again resulted in an outcry in favour of a "White Australia." It is noteworthy that this outcry originated in temperate Australia, which beyond any doubt is a white man's country, as he there finds d climate little different from that of western and southern Europe, or in any case sufficiently akin to that of Europe not to cause any serious problems in acclimatization. The greater part of the population of Australia being found in the south and south-eastparts which require no Asiatic labour and are consequently opposed 
to it-had the predominant voice in the decision and practically stopped the influx of Chinese and Japanese into the north. Tropical Australia suffers and protests, and there the problem remains at present. The advocates of a white Australia keep out Asiatic labour for political reasons and in order to preserve the purity of the white race, but a continance of this policy will delay the development of the tropical north, which is unsuitable for white labour. A territory of many thousand square miles is awaiting the introduction of satisfactory labour to give a good return.

In Natal there have been comparable difficulties with regard to natives of India, but probably in virtue of the climate the white settler will prevail there in the long run.

Closely akin to these labour problems are the difficulties which have arisen in California and British Columbia in regard to the immigration of Asiatics. The entry of Japanese

Emigration of Asiatics has been restricted to a few hundred a year since 1908 , before which there was a steadily growing influx.

The close contact of peoples of widely different economic standards or divergent civilizations always leads to problems of great complexity. In a few cases where the differences

Extinction of Races are not great the two peoples may eventually

fuse. The Maoris and the British immigrants in New Zealand after a long and sanguinary war settled down side by side on a footing of equality. Between the Lapps and northern Norwegians there has been much intermarriage. In other cases the problems are solved by the virtual disappearance of the people in the lower scale of life. The Tasmanian is extinct and the Australian aborigine is confined to the lands the white man does not want. In North America the native Indians are on the road to extinction. In tropical lands little suited for white settlement the disappearance of the aborigines is a much slower process, even if their demoralization is speedy as in the case of the natives of the Pacific islands. It is said to have been the policy of Rajah Brooke in Sarawak to retard the construction of roads and railways in the hope of preventing or at least delaying the exploitation of his country by Chinese and Europeans with whom the natives would compete at a disadvantage. 
In some cases the more efficient competitor cannot displace the native, but the alien culture may sap the long-established one which local conditions have formed and moulded

Caste System for ages. British rule in India, characterized by justice for all and symbolized by railways, roads, educational projects and Christian missions, has done much to destroy the caste system by raising the lower castes from their state of subjection. The result is the growth of a new educated caste which questions authority and is responsible for much of the prevalent unrest.

Asiatic and white man in competition show great rivalry, but a rivalry in which the white man is seriously handicapped. With their undeniable industry and frugality, Chinese

Asiatic and White

Competition and Japanese are an asset in any land where they settle but their simpler diet and cheaper food allow them to undercut their white competitors. This success, coupled with their alien outlook and civilization, makes them disliked by white men in lands where the races meet on equal terms. Hence the measures already mentioned to exclude Asiatics. The outcome of these problems is difficult to foresee, but two tendencies are quite clear. The overflowing populations of China, Japan, and to a less extent India, must find outlets, and the Asiatics will inevitably move to the least crowded lands available around the Pacific.

Temporary migrations of labour to the tropics sometimes occur on a large scale. Especially noteworthy is the influx of labourers from Europe to Brazil for the coffee harvest. Temporary Some 50,000 Portuguese, Italian, and Spanish
Migration labourers arrive in Brazil every year for the coffee harvest and then move on to the Argentine for the wheat harvest and home to Europe.

The most suitable and most available labour for the Panama Canal was found in the negroes of Jamaica and the Barbados. As many as 40,000 of these were working at one time on the canal. Italian labourers are often engaged in large numbers on engineering works in various parts of the world, as on the railways of the United States or in Russian Asia.

In temperate regions labour problems are of a different order if we except such cases, important though they are, of the entry of 
Asiatics into temperate North America. The same race which directs the land can supply the labour. There is no need of introducing people of widely divergent stock;

Demand for

Population in fact every geographical and economic argument is opposed to so doing. New lands in temperate regions can and do become colonies of settlement for people from the overcrowded lands of Europe, and so the problem of labour resolves itself merely into a sufficiency of immigrants. In most new lands the supply is unequal to the demand, and hence the allurements offered to intending emigrants in the form of free grants of land and assisted passages, and the advertisements and emigration offices of the various colonies of the British Empire. Wages are high as a rule because the supply of labour is limited and because the cost of living in a new land which imports most of its manufactured goods is greater than at home. Such new lands begin solely as agricultural colonies, and it is only when population increases that the mineral resources can be developed and manufactures started. An abundance of cheap land means a good return for work and a high standard of living, and so tends to retard industrial development. Or, in other words the scanty population of a new land remains agricultural since that is the path of least resistance. Every man works for himself, and prefers to be his own master rather than become the employé of another.

This state of matters continues so long as there is land available within access of market for the produce either by sea or navigable

\section{A Racial} Danger river, or later by railroad. But when the best lands are occupied, that is to say, best in the geographical as well as the purely agricultural sense, labour fares less well and is easily induced to work for an employer, which in any case ensures a fixed wage free from the precariousness of farming. Growing density of population has thus stimulated industry in Canada, the United States, Australia, and other colonies of Europeans and their descendants. The cry for more immigrants is frequently heard from Australia, New Zealand and Canada, but in course of time this demand will be satisfied without any incentive to emigration except growing economic pressure. And the only urgency in the matter lies in the danger of Asiatics occupying lands close to their home countries, which are unoccupied or sparsely peopled by whites. That of 
course would be a racial danger and a threat to the white civilization.

With questions of labour supply in old countries no space can be devoted here. It raises problems of capital and labour, trades unionism, factory acts and other considerations, economic and not geographical. 


\section{CHAPTER XIII}

\section{RACE TRANSFERENCE AND COLONIZATION}

THE problems of the utilization of tropical lands and the growth of colonies is intimately related to the question of acclimatization, and though a study of this subject introduces ideas that are nongeographical it has bearings of too great geographical importance to be overlooked.

The difficulties of health that Europeans have to contend with in the tropics are well known. No one who has had experience of

\section{Health Difficulties} the tropics can refuse to believe in a kind of degeneration due to the heat that leads to an inability for prolonged arduous work without extreme exhaustion. The period of service in our Indian Civil Service is about twenty years, including leave, after which an official is entitled to retire on pension. The civil and military administrators of tropical dependencies can only maintain their health and vigour by great care and periodic visits to cooler hill stations, or long leave at home. Hence the importance to India, Burma, and Ceylon of such hill stations as Simla, Coonoor, Maymyo, and Nuwara Eliya. This especially applies to women and children who rapidly lose their health in most tropical climates.

The old sea catch "Beware and take care of the Bight of Benin, for one that goes out, there are forty go in," implied no great exaggeration of the deadly nature of the West

Tropical

Unhealthiness
African coast. Sierra Leone used to be termed the White Man's grave and did not belie its reputation. One of the best evidences to-day of the danger of the tropics to Europeans is the extra premium charged by insurance companies for travellers or residents in these climates. The premium is an accurate measure of the risk.

However, a great deal of the deadly reputation of the tropics has always been due to ignorance of the rules of health and to disease. Modern discoveries have done much successfully to combat tropical unhealthiness. Many diseases peculiar to the tropics are more liable to attack Europeans than natives, for the latter have gained a certain measure of immunity. The northern races have not become adapted to withstand such scourges as malaria, 
yellow fever, plague and dysentery, to say nothing of sunstroke. In a similar way the negroes of Africa or the Polynesians of the Pacific rapidly succumb to an introduced disease like consumption, which is epidemic in temperate lands and to which, in consequence, Europeans have attained comparative immunity. Until the source of infection of tropical fevers was discovered little could be done to meet their ravages. Curative methods in themselves were of small avail until preventive measures could be taken.

In this connection is one of the most striking examples of the value of scientific research. The bacteriologist working in his laboratory detected a parasite in the blood of Value of Scientifle the patient and traced it to the mosquito which Research acted as a carrier. The problem then admitted of solution. Keep the mosquitoes away from man, or better still exterminate them, and there will be no more malaria or yellow fever. Work on these lines in many parts of the tropics has led to speedy and striking results. In Havana city, Cuba, the Americans almost wiped out yellow fever in a year. In the Panama Canal zone they reduced the white death rate from 60 per 1,000 to less than 10 per 1,000 in a few years, and made Panama city almost a health resort.

The bacteriologist, quite as much as the engineer, made the Panama Canal. The same story could be told of malaria, yellow fever, and other tropical diseases wherever adequate preventive measures have been put in force. Many of the towns of West Africa, especially French West Africa, have been cleansed of their evil reputation for fever, and in time to come these diseases may be as rare in towns as small-pox is in this country. But to exterminate the mosquitoes and other disease-bearing insects throughout tropical dependencies would be an Augean task. In course of time a great deal can be done; meanwhile, armed with the knowledge of the source of infection, the white man can take necessary precautions and hope to escape attack.

Important as these discoveries are, they do not touch the problem of the acclimatization of the race. Preventive medicine affects the individual and lessens the cost in lives of

Acclimatization directing and controlling tropical dependencies, but it does not bring any nearer to solution the settlement of the tropics by white peoples. A race, to be 
acclimatized, must be able to live generation after generation in the new environment, with undiminished vigour and unlessened fertility, and without periodic transference to a cooler climate or admixture of fresh blood. Unless these conditions are fulfilled the race is not at home in its new environment and there can be no question of acclimatization. This problem does not arise in the transference of a race, or part of a race, to a climate similar to its own. When British colonists go to New Zealand or Canada they find a cool temperate climate, not, it is true, identical with their own but in neither case so widely different that their mode of life has to be changed.

Since civilization has developed in temperate regions while the tropics have always been the home of backward people, the problems of acclimatization are mainly those of

Transference peoples from temperate lands settling in tropical of Tropical
Races races to higher latitudes-the only example on a large scale is the influx of African negroes to North America. But since as a race they have remained in warm, temperate and subtropical North America their case does not throw any light on the problem. The fortunes of individual negroes, or even of a few families in cool temperate climates, proves nothing and so need not be considered. ${ }^{1}$

Much of the wastage of life in the tropics is due to preventable disease, but apart from that there is no evidence to show that white races can fulfil the conditions of acclimatization in tropical lands. Throughout the tropics it is found necessary to employ native labour, or in the event of this being unsuitable or unobtainable, to introduce alien subtropical labour (p. 97). Nowhere has colonization of warm lands taken place from cold.

Experiments in this direction in various tropical lands have invariably met with failure. A single instance may be cited. In the Bahama Islands there is a number of white Degeneracy settlers, in the main descendants of colonists in Resulting from America who left the United States a century and a
Transference half ago on the American declaration of independence. Most of the present generation of white descendants have

1 During the years 1914-1917 there was considerable migration of negroes from the southern to the northern United States, the total being said to amount to about half a million. This movement was probably due to temporary conditions. It is yet too early to judge its effect and success. 
degenerated in physique, energy, and culture, approximat ely to the negro standard. The only real distinction between the two races in the Bahamas to-day seems to lie in the greater mental capacity of the white, a racial attribute beyond climatic control. And this is in a climate which is merely subtropical, without the extreme heat and moisture of equatorial climates.

All available evidence goes to prove that there is no such thing as acclimatization in the human race by transference of a community to a widely divergent climate. Climates, however, are not as a rule separated by well-defined boundaries. Intermediate or frontier climates may not prove drastically unsuitable to two communities both of which enjoy a climate not markedly different from the one in question.

It must, of course, be admitted that gradual acclimatization with the help of natural selection has occurred. It is only in this

\section{Gradual} Acelimatization way that the world became peopled with the human race. The slow adaptation of racial stocks to new environments by the gradual elimination of the least fit is the only possible explanation of the present distribution of man. In that way no doubt the white races could colonize tropical Africa moving slowly through many centuries via immediate climates. But that, of course, is not a practical policy for any state to pursue. Moreover, there is every probability that the human type which eventually would evolve as most suitable to the tropical climate would be lower in mental energy and cultural ability than the people from which it sprung. At least that is what the characteristics of tropical peoples suggest.

The significance of these considerations in problems of colonization is great. The colonies of settlement of the white races are all in temperate climates. The northern Europeans

Colonization go to Canada, the northern United States, southern ISouth Africa, Patagonia, temperate Australia, or New Zealand. Many Russians migrate eastward in more or less the climate of Russia into Siberia. The southern Europeans, with their more subtropical Mediterranean climate, find homes also in the warmer regions of America such as the southern United States, Mexico, southern Brazil, and the Argentine.

It should be noted that in many of these cases altitude compensates for latitude, and though a place may appear to be in the 
tropics its elevation gives it a temperate climate. For these reasons Rhodesia and many parts of the East African plateau can be successfully colonized by Europeans. The regions of East Africa at an elevation of over 5,000 ft. although they lie in the tropics, come within this category. The southern temperate provinces of Brazil have large numbers of German, Austrian, and Russian settlers.

The Chinese have probably a greater power of expansion than Europeans because their lands have a range of climate from cool

temperate with great extremes to subtropical

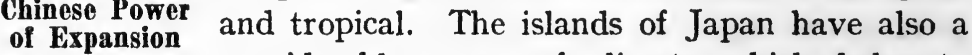
considerable range of climate which helps to widen the possible scope of Japanese oversea settlement.

The story of the attempts at colonization of Algeria and Tunis forms a valuable commentary on the question of acclimatization.

The Vandals, in the fifth century, had little suc-

Unsuccessful

Attempts at

Colonization

cess there, in contrast to the Arabs from Arabia, with its similar climate, two centuries later.

Other Mediterranean people, Phoenicians and Romans, had found no difficulty in accommodating themselves to the conditions of environment. Last century, after the French had became masters of Algeria, attempts were made to settle European colonists on the soil. Practically the only ones who succeed are those from Italy, Sicily, Malta, and Mediterranean France, that is, say, those who transfer from a similar climate. The northern French have little success: the Alsatians and the Germans fail. It is not a question of disease but of dwindling strength and decreasing birth-rate coupled with an inability to meet the unaccustomed conditions of agriculture and new ways of life that the climate demands.

The true measure of success of a colony is neither the number of immigrants that enter it nor the volume of trade per head of the inhabitants. Both these figures are frequently

Guide to

Prosperity cited but both are fallacious as an index of prosperity. The rate of natural increase of the population, or in other words the excess of births over deaths, is a surer guide. If the birth-rate is maintained well in excess of the death-rate the prosperity of a colony is fairly certain. Its future probably lies in the hands of those elements of the population 
with whom the birth-rate is highest. Thus, in South Africa the balance is in favour of the Dutch element. The entry of British colonists is small and their birth-rate is low. Unless they increase rapidly the Boers and Cape Dutch will swamp the British and the negroes will outnumber both.

The estimate of a country's prosperity based on this numerical criterion must not be pushed too far. Quantity is often less important than quality of population. France

Quality of has an almost stationary population, yet the French nation not only maintains but enhances its greatness. And even in a new country numbers are not all important if the quality is low. The self-governing Dominions and the United States are now taking great pains to refuse entry to immigrants undesirable on physical or moral grounds.

It must not be forgotten that in a young colony the figures for the birth- and death-rates will show anomalies in the beginning that will probably disappear as the colony grows

Birth and

Death Rate Statistics and gets into its stride. In its early days a colony consists mainly of young people in the prime of life and consequently its birth-rate is high: as time goes on the population gradually gets its normal proportion of old and of children, and so statistics show an apparent decline in the birth-rate which is not real. Fallacious arguments have been based on this to prove that Australia is unsuitable for Europeans. Take the case of New South Wales-a fall in the birth-rate from 42 per 1,000 in 1860 to 28.9 per 1,000 in 1914 looks alarming but in reality can easily be explained, and in point of fact the figure for 1914 is considerably higher than in most parts of the United Kingdom. Arguing from the high proportion of young people and the absence of old in a new colony one might expect a low deathrate. But the proportion of accidents among pioneers is high, and medical help is often unobtainable. These reasons and the hardships inevitable in the early settler's life, give a high death-rate. Infant mortality is one of its largest factors. In after years the death-rate falls, and in the course of several generations steadies at a certain level, which may be taken as an index to the health of the colony.

Furthermore, in examining the vital statistics of any colony distinction must be drawn between the natural increase, which is 
excess of births over deaths, and the increase of population due to immigration or excess of entries over departures. Unless these distinctions are borne in mind statistics Distinctions to may be unduly misleading. A steady increase in
be Borne in Mind both will bring prosperity to a colony; a rising natural increase will do the same but at a slower rate, while an increase alone in the excess of entries over departures-if such ever was the case-would promise ill for the future of the colony.

Lastly, a word of warning is not out of place as regards the population statistics published by various colonies. Entries alone are not sufficient: departures must be deducted.

Misleading Statistics

The immigrants to the United States are swollen in numbers by the settlers en route for Canada via United States ports, and the entries to Australia include many immigrants who merely tranship at Sydney for New Zealand. Some South American statistics are most misleading as they involve no mention of the departures. In the Argentine some thousands of Italian labourers arrive annually for the wheat harvest and leave for Italy when it is over. The inclusion of these among the immigrants, without any corresponding deduction, gives fictitious value to the published figures.

A consideration of the motives which lead to emigration and colonization involves first of all a word by way of definition. The wor d "colony" is derived from the Latin colonia,

The Term "Colony" meaning a possession in land or a farm, hence an abode or dwelling and a settlement: The allied word colonus means a husbandman or tiller of the soil. In its literal meaning "colony" conveys the idea of a landed possession where agriculture is the chief occupation, and a colonist in the true meaning of the word is an agriculturist or peasant. The term " colony " should be restricted-in the cause of clear thinking - to a possession in which definite settlement takes place wholly or mainly by people from the home country, to which in fact there is definite race transference accompanied by transference of language, icustoms, and social institutions-in short a transference of civilization. The idea implies, in the beginning at least, the common nationality of the original settlers until such time as the colony has evolved its own nationality, with or without separation from the nation 
that gave it birth. The colony is then in a position to assimilate emigrants of divers nationalities without any drastic change in its social state and civilization. Any possession that does not embrace these characteristics, at least in large part, is not properly speaking a colony, but a dependency of the home country. In practice the terms are often loosely employed, yet the distinction as a rule is marked even if there are a few anomalous cases.

Colonies generally owe their origin to the more or less unconscious action of the democracy of a country in contrast to dependencies which originate more often in the Origin of Colonies conscious action of a government, whether the dependency is acquired by military conquest, as Gibraltar, or by annexation of a trading area, as the Gambia and many other African possessions of Britain and other European countries.

The empires of Rome and of Spain, as the present French empire, were acquired by the action of the central government either by military conquest or by annexation, previous to any form of settlement. On the other hand, our colonies in North America and in New Zealand originated in settlement by adventurous emigrants before annexation took place. There are, of course, cases in which these distinctions tend to break down. A dependency may take on the characteristics of a colony. East Africa is a case in point, although the change is only beginning. South-West Africa will furnish another instance in years to come.

It is noticeable that Europe, China, Japan, and to a less extent India, are the lands of origin of the true colonizing peoples. They

\section{Colonizing} People have provided, and still provide, from their dense populations colonists for the less crowded lands. The motives that have resulted in the growth of colonies are varied, and though some of them are not geographical they cannot be ignored here on account of their wide-reaching geographical results. It is suicidal to geography to narrow its outlook.

It: was a desire for spiritual freedom which drove the Puritans in 1620, to set sail in the Mayflower, and by the foundation of New Plymouth in Massachusetts' Bay, to. lay the foundations of the present-day United States of America. It was a similar need for 
religious liberty that drove the Huguenots to South Africa in 1688 and the Doukhobors from Russia to Canada in 1898. Finns, in order to escape Russian tyranny, used to go to the United States in large numbers. The results in all cases were beneficial to the lands that received the refugees, for men and women whose liberty of conscience means more to them than home ties and their native land have grit and determination beyond the ordinary and are the very people best suited to develop a new land. When Ferdinand and Isabella, in 1692, expelled the Jews from Spain, Holland and England benefited by the settlement in these lands of cultured Jews. The agitation against Jews in southern Russia a few years ago did nothing but good to Italy and southern France and harm to Russia.

In passing it might be noted that a selfish argument against the foundation of a Zionist state in recaptured Palestine is, that if the new state proves too attractive, it will rob Europe of some of its most capable human stock.

In the main, however, two motives have been at work, and are always at work in the growth of possessions, first, the desire for trade, and secondly, the need of new agricultural

Growth of

Possessions land to relieve the pressure at home.' The desire for trade leads to the formation of trading stations and dependencies : this is discussed in Chapter XV. The other motive, pressure of population, results in the settlement of new and relatively empty lands having more or less the same environment as the mother country. It signalizes escape from a less favourable environment to a more favourable one, just as the emigration of people to ensure spiritual liberty marks the search for a freer intellectual environment. In Chapter XI are discussed the varying degrees of density which population can attain. It was seen that in land largely devoted to industry population increases most rapidly and out of all proportion to local resources. Hence such lands tend to have a large proportion of over-crowded towns, and people whose prosperity depends entirely. on the state of employment. A bad state of trade means many thrown out of employment. To them emigration is specially attractive as it offers a sure livelihood. But on the other hand urban dwellers do not make the best colonists, for what the new colony wants above all is agricultural settlers. 
Crowded lands supply plenty of these, especially when the colony can offer more attractive conditions than the home country. The Irish famine of 1846-7 started the flood of Irish

Causes of Emigration emigration to America, and the stream from the poor lands of Scotland to the richer fields of Canada never ceases. Scandinavians must become sailors or emigrate : the unproductive lands can support but a limited number : men must be exported. Hungarians and Austrians crowd over the seas. Many Germans used to go to Australia, since the days when Germany began her career as an industrial land. Portuguese and Spaniards seek new homes in South America in the civilizations which are essentially their own. Italians leave Italy in numbers : almost any land could offer them a better living than the unproductive soils of the greater part of southern Italy, mountainous and deficient of water and often on the lower ground rife with malaria. France sends few emigrants overseas but France is in the main a rich agricultural land with so low a birth-rate that its population is practically stationary. An agricultural land breeds a population sedentary in proportion to the richness of its fields, and if in addition it has no surplus there is no incentive to emigration.

Most of the lands of the world suitable for colonization by Europeans are, or have been held by Britain. She was first in the field and the first to become a manufacturing Great Britain as Colonizer land with a crowded population and a need for raw materials and food. It was only when Germany became an industrial country-about the middle of last century-that she acquired any overseas possessions, but she was too late to acquire colonies. The British colonies have now all attained virtual independence. America broke off in 1776 and became a separate power. Canada, Australia, New Zealand, and South Africa are, to all intents and purposes, independent powers bound by common interests to the home land and so to one another.

It is noticeable in reference to what has been said before (p. 110) that all these colonies, including the United States, owe their chief

Agricultural prosperity to agriculture in some form or other.

Resources

and Success

The richness of their agricultural resources is a measure of their success and wealth. Canada is the best of all our colonies, but Canada is older than the others, and being nearer home draws a large proportion of the emigrants 
who seek new lands overseas. New Zealand has, on the whole, a climate more similar to that of Britain than any other colony, a factor which, despite the great distance of New Zealand, has always favoured its settlement and progress. Canada, New Zealand, Victoria, New South Wales, Tasmania, south-western West Australia, the more fertile parts of Cape Colony, and the northern states and California in the United States, absorb the British emigrants. No other part of the world as yet serves as an outlet for our surplus population.

The figures vary from year to year but in 1913, the last normal year, about 40 per cent. of British emigrants went to Canada, about 27 per cent. to the United States, about

\section{British} Emigrants 17 per cent. to Australia and New Zealand, and less than 5 per cent. to South Africa. The remainder went partly to other lands in the British Empire but largely to foreign countries.

All these emigrants, of course, do not settle on the soil. Agriculture and pasturage attracts most but mining takes a good number, and with the growth of industries in these new lands and the spread of urban areas many immigrants remain in the towns. In Australia this is one of the least encouraging features of the times. Forty per cent. of Australian population is urban.

The United States receives a medley of all the peoples of Europe. It is a veritable melting-pot from which emerges the characteristic American type. Britain is the only nation in Europe (if Russia with Siberia is excepted) whose emigrants can find a home in her own colonies. The nationals of other lands have to adopt a new nationality and are permanently lost to the mother land.

While numbers of Russian emigrants used to go to the United States others took advantage of the inducements offered them to settle in Siberia. It will be long till Siberia

Russian Emigrants outlives the bad name which its sole use as a convict settlement gave it in the past. Exile to Siberia was abolished in 1900 but restored for political offences in 1914. Western Siberia, however, is really an attractive land and until the war and subsequent upheaval in Russia was annually drawing numbers of emigrants from European Russia and Finland.

Under the Tsar's regime the Russian government did much to 
encourage emigration from European Russia to Siberia by grants of land, loans, nominal railway fares, and exemption from military service. Land was granted for the perpetual use of the settler but it remained state property and he had no right to sell or mortgage it. The classes from which emigration were drawn were settled by state decree under the hide-bound regime of the Tsar. From 1896 to 1905 about $1,000,000$ settlers entered Siberia. Then there was a great increase, the annual number growing in 1908 to over 660,000 , subsequently falling gradually to about 200,000 at which it stood when war broke out. Since then no figures are available.

During the war emigration from Europe ceased, at least as far as males were concerned. The requirements of the army and allied

War's Effect on Emigration occupations absorbed all the surplus population with ease. This applied to practically all countries of Europe. And a reversal of the usual movements of population set in by the despatch to Europe of large contingents of troops from all the British colonies. This, of course, was but a temporary movement as most of these troops returned in the course of time to their civilian occupations in the colonies. But meanwhile, by the depletion of their male population, the progress of the colonies was seriously curtailed, more so than the home country which at all events had a large female population available to maintain most of the essential occupations. There can be no doubt that before long a stream of emigration will set out from the British Isles and many other European lands. Already there is an increase in the proportion of female emigrants who in former year were not equal in numbers to males. This will help to equalize the proportion of the sexes in the new countries.

In the Eastern world India, China, and Japan all send out large numbers of emigrants annually, partly in the form of contract or coolie labour as far as India is concerned (Chapter $\begin{array}{cl}\text { Eastern } & \text { XII). While this occurs also from China and } \\ \text { Emigration } & \end{array}$ of free settlers to tropical and warm temperate lands. The difficulties resulting from competition with white settlers are discussed in Chapter XII. In Formosa, and later in Korea, Japan has had her own way with no European competition and with either a little civilized or a scanty population to face. Both these lands 
have become Japanese colonies. Manchuria annually receives a large influx of Chinese settlers, and the same is occurring in the Amur region further north, a province of the late Russian Empire too remote to attract Russian settlers until nearer Siberia is fuller than at present. 


\section{CHAPTER XIV}

\section{TRANSPORT AND COMMUNICATION}

\section{LAND TRANSPORT}

IN all forms of trade, whether barter or modern commerce, an essential consideration is transport. Obviously the topography of the land has considerable influence on the means

Influence of

Topography of land transport adopted. Communication over mountains is difficult compared with the ease of movements over plains. Hence the easy conquest of plains and the difficulties of invasion in mountainous countries. A recent illustration was the German invasion of Belgium and France in 1914, and history affords many comparable examples. The Blue Mountains of Australia pent the early colonists on the Pacific coast for some fifty years until the difficult crossing to the plains beyond was accomplished; and the rugged afforested Appalachians stemmed the tide of settlers on the coastal plain of North America. The geographer finds a fundamental explanation of the growth of Prussian power in central Europe in the ease with which the north German lowlands were unified by virtue of facility of communication and transport.

The development of means and methods of transportation are of great importance. Their change from age to age gives varying value to topographical features as factors in geographical circumstance. Advances in mechanical skill are always tending to lessen the effect of physical barriers and by shortening the time of journeys to facilitate intercommunication. Man is continually reducing the value of distance by accelerating speed of travel : as the remotest lands are brought closer to one another the world becomes smaller.

Man himself was the earliest beast of burden and under some circumstances remains the chief transport agency to-day. In both tropical Africa and America porters are

The Human Carrier almost the sole carriers and are being replaced by railways on only the great arteries of traffic. Along jungle paths and through swamps the human carrier is the only feasible transport agency until European skill has built a hard broad road suitable for wheeled traffic. Since an African 
porter carries a weight of only some $60 \mathrm{lbs}$. this form of transport is wasteful of human labour. Chinese porters carrying tea over the mountains into Tibet are said to carry $200 \mathrm{lbs}$. each at a rate of 6 to 7 miles a day for twenty days. The Newhaven fishwife rivals this feat with her load of $224 \mathrm{lbs}$. carried several miles in hilly Edinburgh. In frontier lands the prospector carries his kit on his back and the explorer often has no other means of transport. The employment of human porters frequently leads to slavery (p. 140).

The replacement of human porters by domestic animals is a great economy. The animals principally employed differ in various

\section{Animals Used} lands, some being more efficient than others. for Transport The horse needs good nutriment and is more useful in plains than among hills. In many parts of the tropics it cannot be used owing to its liability to attack by disease-bearing insects. The ass and mule can thrive on poor grasslands and the latter is specially valuable in mountainous districts. Mountain gun batteries are drawn by mules. The ox is used in some parts of Europe and South Africa, the llama in the Andes, and the yak in the Himalayas. The camel can live and prosper in conditions too desertic for any other beast of burden, for it can do without water for six or seven days at a stretch.

The camel has justly been called the ship of the desert since without it the hot deserts of the world could not be traversed. In Arabia and the Sahara the camel is the principal

\section{Camel \\ Transport} or only beast of burden, and it is used also in western Asia and in the dry lands of Australia. The single-humped camel or dromedary of Arabia and the Sahara can carry an average of $400 \mathrm{lbs}$., but the double-humped one, a larger species, can take twice that load. Transport by camels is generally organized into caravans which may contain as many as 500 or 600 animals. A caravan has the drawback of travelling not more than about 25 miles a day.

The elephant is a beast of burden in south-eastern Asia, but the African elephant is not thus employed nowadays. The elephant can carry enormous weights and is particularly Elephants as
easts of Burden valuable in jungle lands devoid of roads. In the Malay Peninsula, for instance, much tin is brought down to the coast for shipment on elephants. The elephant can also be taught to lift heavy loads like the famous teak-lifting 
elephants of Burma. So valuable are these animals that the hunting of them throughout India and Burma is under government control.

Where the ground is covered with snow in winter animals are often used to draw sledges. This facilitates transport. The horse is thus employed on the snows of the Russian Animals winter, or the reindeer in Lapland, or the dog Transport. among the Eskimo of Greenland and Arctic Canada. A reindeer can run about 100 miles a day with a half-ton load on a sledge, or a team of ten to twelve Eskimo dogs can pull nearly the same weight, over hard snow, for about eight hours.

The most economical way of using beasts of burden is with wheeled carts. Occasionally these are drawn by men, as in the jinrickshaw of Colombo or Japan, or the hand

Use of

Wheeled

Vehicles barrow of the street hawker. Whatever animal may be employed with a wheeled vehicle, greater efficiency is assured than if the same animal is burdened with packs. A horse can draw 2 to $2 \frac{1}{2}$ tons, but on his back can carry not much more than about $200 \mathrm{lbs}$. Other animals are occasionally employed, such as oxen in many parts of Asia and South Africa or on the plains of the United States, or the dog for light vehicles in Belgium and Germany.

Wheeled vehicles, of course, necessitate some sort of road, the smoother the better, so that their use restricts traffic to certain routes. Good roads are quite a modern invention. English
Roads True, there were tracks in England at a remote period, but these were largely used for packhorses. Similar tracks are formed to-day in new colonies before the growth of population results in metalled roads. Old English roads were probably far worse than any of our country lanes. The Romans built good paved roads, which ensured communication and traffic with a minimum waste of time and energy, and so were a help in Roman domination. But from the Roman days until modern times our roads were again little better than tracks. In bad weather drivers left the tracks and took their carts over the adjacent land, with the result that the roads grew in width every year. Evidence of that can be seen to-day in the wide strips of waste land that lie on either side of many of our main roads. 
Modern road-making in Britain dates from the beginning of the nineteenth century and in France from the initiative of Napoleon I. Many countries are still ill supplied with good roads. In Russia there are few and in France beyond the wide straight military routes the roads are poor. Britain has better roads throughout than any other country, but they vary in different parts, largely with the road metal available. The gluey winter mud and the white summer dust of Derbyshire roads are common to all limestone districts if no other road material is at hand. Basalt, if available, is frequently used to obviate these drawbacks. In regions of new rocks road-making is most difficult, and the metal generally has to be imported.

A later development of roads is their use for motor vehicles. In recent years a certain amount of heavy traffic has abandoned railways for roads. Passenger traffic, especially

Advent

of Motor

Vehicles in the vicinity of large towns, has done so to a great extent. Year by year motor buses push their routes further out into the country. Many of the Post Office parcels mails are now roadborne. This revival in road traffic has effect on the nature of the roads. New methods of preparing the surface have been invented, roads are widened, and many of the curves are softened. Some roads that were falling into disuse have once again become arteries of traffic. The effect is noticeable in many old English inns with their broad archways, roomy courtyards and ample accommodation for man and beast. After a period of neglect when the railway robbed the road of nearly all its traffic, some of these inns are coming into their own again with stables transformed into garages.

The railway strike of 1919 demonstrated in a remarkable way the extent to which motor transport can serve the needs of the country.

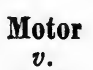

Rail In a few days'time, thanks largely to the legacy of motor wagons which the war had left to the country,

a fairly efficient service of road transport was organized for the food supply of the country. If the stoppage of the railways had continued much longer several of the motor routes might have become established rivals or adjuncts to the railways.

In order to decrease the friction between the wheels and the ground, and so reduce the amount of energy required in transpcrt, 
parallel lines of smooth stones are sometimes laid along a road. A further step was to fix metal rails and thus the tramway originated. On a tramway a horse can draw a much greater load than on a road. Horse tramways are still used Tramways in collieries and other mines: until recently they were to be seen in the streets of Oxford and are still in use in a few leisurely watering places. The tramway has followed an evolution of its own principally as a conveyance for passengers within urban areas. In nearly all large towns the electric tram has superseded the horse, cable, or steam tram. The latest development is the trackless tram run by trolley wires but on ordinary roads without rails. Tramways occasionally run far into the country leaving the road and becoming light railways beyond the town area as in Dublin and Sydney, N.S.W. Owing to the speed that can be attained by means of electric propulsion tramways enable people to live far from the heart of a town and yet reach their work quickly and relatively cheaply. They have stimulated the growth of towns along their routes and have been the cause of moving radially outwards the residential quarters of wage earners and less highly paid professional classes. In parts of Lancashire and Yorkshire where the spreading towns closely adjoin it is possible to travel from town to town by tramway. There are practically continuous routes between Leeds, Manchester, and Liverpool.

From the tramway there evolved the railway although, in point of fact, it came after an age of canals. With the invention of the steam locomotive in the nineteenth century Railways railways spread throughout the civilized world. Afghanistan is the last remaining country without a mile of railway.

Generally railways have more or less followed the routes of roads but railway gradients must be as easy as possible, if speed is to be maintained : this has entailed the construction of embankments and cuttings and the boring of tunnels. Although more dependent on physical relief than roads, railways have a much greater efficiency for traffic and so have been constructed in many lands before roads at considerable difficulty and cost.

Railways pushed ahead of civilization open new countries to settlement or exploitation. Distance from centres of population 
in many cases is too great for any other form of transport. The Canadian and Siberian railways are examples of lines that have opened up new countries. Without railways linking their capitals the union of the Australian colonies into a Commonwealth would have been impracticable and probably never seriously considered. The great distances which separate Adelaide, Melbourne, Sydney, and Brisbane are overcome only by fast trains which make a common government possible. The new transcontinental line in Australia also brings the Commonwealth into closer relation with Britain by decreasing the time spent in transit by passengers and mails (p. 195).

Railways foster the exploitation of minerals in lands difficult of access, or unproductive. The Swedish iron ores of Gellivara find a quick and ready outlet by rail at the Atlantic

Railways Facilitate Mining ice-free port of Narvik in winter. Finland being practically cut off from overseas communication in winter by the freezing of its Baltic coastal waters seeks a strip of territory from Norway or Russia through which a railway can be built to an open port on Varanger fjord. Similarly, northern European Russia used to have its only winter outlet to the ocean by the single narrow gauge line to Arkhangel. This slender line of communication proved totally inadequate when the European war, closing all other land and sea routes, made Russia practically dependent on Arkhangel for communication with her European allies. The Arkhangel railway was widened and double-tracked, while the work was pushed on so rapidly on the new Murman railway that a temporary line was ready for use in 1915. The Murman railway leading to Murmansk, on the Kola Inlet, gives Russia a winter ice-free port.

In the arid interior of New South Wales the silver and lead ores of Broken Hill and the copper of Cobar are mined extensively by the help of railways to the coast.

The value of railways in war for the rapid transport of men, food, and munitions is enormous. Without the network of field railways along the Allies' western front successful Railways operations against Germany would have been
in War impossible. The Trans-Siberian railway allowed Russia, in 1905, to wage a war against Japan over 5,000 miles from home. Later, under changed conditions, the same railway served 
Russia for the importation of Japanese arms and ammunition for use in Europe.

The British campaign against German South-West Africa demanded the linking of the British and German railways at Kalkfontein, while it was the Herero rising some years previously that had led to the German line from Lüderitz Bay.

Uniformity of gauge within any country is most important. In Great Britain there is now only one gauge but on the mainland of Europe there are several gauges. This does not

The Rail Gauge necessarily mean break of bulk in transferring goods across the frontier, since wagons can be built with adjustable wheels, but it entails delay and discourages the speedy and frequent intercourse so necessary for the growth of good relations between contiguous people. Sometimes this difference in gauge between adjacent countries was for purposes of defence. The standard Russian gauge of $\mathbf{5} \mathrm{ft}$. is said to have been chosen in order to prevent German rolling stock being serviceable in Russia. The principal Indian gauge is $5 \mathrm{ft} .6$ in., which will not permit Russian wagons to run in India in the event of central Asian lines being extended to the Indian frontier.

The break in gauge between the railways in Cape Colony and those in South-West Africa promised to be a hindrance to General Botha's troops in 1915. The Germans themselves, with widely different intentions, helped to remove this difficulty. As they retreated before the advancing Cape forces they removed the rails to hamper pursuit. In reality this action saved the British the labour of removing the narrow line before laying their own wider gauge and so facilitated General Botha's advance.

Light railways are coming more into favour largely as the outcome of experience during war when they served the battle areas.

A line of $2 \mathrm{ft}$. gauge can be constructed more

Light

Railways cheaply and quickly than a standard gauge line, and being able to negotiate sharp curves, is useful in a rugged country. Light steam locomotives burning wood, coal, or oil are the means of traction employed.

\section{RIVER TRANSPORT}

Transit by water has attracted man from his earliest days because of its ease and cheapness. To navigate a river, as every 
school-boy knows, needs little skill or experience in boat-building. Rivers were the world's earliest highways, and river basins gave birth to all the great civilizations. Primitive man

The World's has always devised some means of utilizing rivers Highways whether by a dug-out, a simple boat, or a birchbark canoe, and the evolution of the sail naturally followed. Every people has its own type of boat and sail adapted to its own special requirements. Even in treeless countries boats are fashioned by stretching skins over reed or willow frameworks. Rivers are highways provided ready for man's use and entail no cost of upkeep. In low-lying alluvial lands, in some climates most favourable to human progress, rivers have low gradients and so are easy to navigate : moreover, they are specially desirable highways owing to the difficulty of road construction in the soft soil.

Before modern road-making was invented rivers were of course of more use to man than to-day, but provided only that they are navigable for larger vessels they are still of prime

Importance of River Transport service, even if railways have somewhat diminished their importance in many lands. The incomparable waterways of the Mississippi system before the railroad era were busy steamer routes through the great plains of North America. The wharves of St. Louis, in the heart of the system, and New Orleans at its sea outlet were hives of activity. The Amazon, navigable from the sea to the foot hills of the Andes (even a British cruiser once went to Iquitos, in Peru), is the only streak of civilization in the wilderness of the Brazilian forest. All the great rivers of Africa, Nile, Zambesi, Congo, and Niger have steamers on their navigable stretches which are linked together in most cases by railway tracks. So important was the Congo considered as a highway that during the scramble for Africa, towards the end of the nineteenth century, the European powers agreed that it should be open to the vessels of all nations. Later, in 1911, on the readjustment of the divisions of the Congo region Germany's successful demand that her Cameroon territory should touch the River Congo in two places was eloquent of the value of that river in trade. The right of navigation of the River Uruguay was for long a source of contention between Brazil and Paraguay and some sixty years ago led to war between those two republics. 
The Treaty of Versailles indicated the value of rivers in its clauses which made international the waterways of the Danube below Ulm, the Niemen below Grodno, the Oder from the heart of Silesia and the Moldau and Elbe from Prague.

Rivers opening to remote or ice-bound seas like the $\mathrm{Ob}$, Yenisei, Lena, and other great rivers of Siberia, which are frozen for several months in winter, are of little use for external communication.

It often happens that a river can be made navigable to vessels of modern requirements by dredging, removal of rocks, or local canalization in places. Navigation on the Danube

\section{Local
Canalization} was for long impeded at the Iron Gates, a series of rocky defiles 60 miles in length where the river passes through the Alpine folds, but effective blasting cleared a channel, and since 1896 the river has afforded passage into the heart of Hungary for small vessels. Many English rivers have been canalised in places to allow barge navigation from the coast ports to the heart of the industrial area. Recently it has been decided to dredge the Trent sufficiently to allow sea-going vessels to reach Nottingham.

Before dredging was undertaken no vessel drawing over $12 \mathrm{ft}$. could depend on reaching Montreal from the sea. Now there is a depth of $30 \mathrm{ft}$. and dredging is to be continued until a channel of $40 \mathrm{ft}$. is available from the sea.

In the case of comparatively few rivers is navigation practicable by sea-going vessels, because most large rivers have deltas whose shoals afford an impediment to deep-draught vessels. The Mississippi system or the Ganges, or on a smaller scale the Rhone or the Rhine, are good examples of this. But vessels of 2,500 tons can pass the Danube delta and ascend the river as far as Galatz.

\section{CANALS}

Navigable rivers are often connected with one another by canals, thus affording a cheap and satisfactory system of inland communications. A great deal more might be done Neglect
of Canal System in this direction in many countries, and there are numerous examples of canals, especially in England, which have fallen into comparative disuse and often bad repair, which might be improved and with advantage utilized for the more bulky commodities of commerce. 
By canal and river it is possible to pass across England between east and west, or from the Thames to the Mersey or Humber. In the plain of Germany canals have been constructed and Continental Canals to connect the navigable rivers, thus affording east and west as well as north and south routes.

Projects to improve the connections between the Rhine and Danube, and the Danube and Elbe, have also been suggested. The Dortmund-Ems canal was constructed to afford an outlet through German territory for the industrial area of the Ruhr coalfield in Westphalia, the products of which formerly found their way eastward by the Rhine to Rotterdam. From Emden a canal leads to Wilhelmshaven, the German naval harbour on the North Sea, thus affording a direct route for war material from Essen to the sea.

The many deep slow-flowing rivers of the Russian plain have been connected so easily with one another by canal that waterborne traffic in vessels up to 1,000 tons burden can pass from the Caspian Sea to Petrograd and Kronstadt. In this way wheat from the south and timber from the north-east reach the Baltic for shipment.

In North America canals are of great importance and many more might with advantage be constructed. The Erie Canal, built in 1825, from Buffalo on Lake Ontario via the North
Ameriean
Canals Mohawk valley to Troy on the Hudson River, affords easy transit between the great plains and the port of New York. The construction of this canal is said to have made possible the export of flour via New York which was formerly impracticable owing to the cost of overland freight, and it had no little influence on the growth of New York to its position of ascendancy among American Atlantic ports.

The great lakes of North America are connected by canals forming the finest system of inland navigation in the world. The Welland Canal, 27 miles long and $14 \mathrm{ft}$. deep, links Lake Oritario with Lake Erie, overcoming the interruption in the Niagara River caused by the Niagara Falls. Lakes Huron and Superior are joined by the Sault Ste. Marie canals, generally known as the "Soo" canals, one on the Canadian, and two on the American side of the rapids. These three canals, and especially American ones, carry annually some $60,000,000$ tons of freight. 
The great lakes, aided by these canals, afford a waterway 1,410 miles in length. Specially constructed steamers of shallow draught are employed. The depths of the canals determine the draught, but many of the steamers are equal in size to ocean liners. The cheapness of this form of transport compared with railways is remarkable. To ship iron-ore by water from the west of Lake Superior to the manufacturing centres on Lake Erie cost before the war one-fifth of the charge by rail.

Physical factors are of great importance in the construction of canals. Over level plains the cost is, of course, least, especially if little or no blasting of rock is required. For this Canal
Construetion reason canals often wind considerably in order to maintain the same level. But few canals can be constructed without locks. This adds to the expense and the delay in transit, but with a sufficient number of locks considerable elevations can be surmounted. The Welland Canal with twenty-six locks, reaches a level to $246 \mathrm{ft}$. above sea-level in Lake Ontario to a level of $572 \mathrm{ft}$. in Lake Erie. In the course between Montreal and the head of Lake Superior a vessel has to rise $551 \mathrm{ft}$. and pass forty-eight locks.

The Trollhättan-Göta Canal, which links the Kattagat with the Baltic via the great lakes of Sweden, has sixty-four locks and rises from sea-level to $300 \mathrm{ft}$. To surmount the Falls of Trollhättan there is a veritable ladder of six locks.

The Huddersfield Canal, in the north of England, passing between the Calder and Mersey pierces the Tame-Colne water-divide in a tunnel over three miles long.

A consideration of great importance is the water supply for a canal. A sea-level canal is of course supplied from both ends, but a high-level canal must have its supply Canals
and Water
Supply renewed either from rivers or reservoirs at the highest level, since every time a vessel passes through a lock a quantity of water is lowered from a higher to a lower level.

The most modern phase of canal construction is the ship canal suitable for the large vessels of modern commerce. Most of these are so important that they must be considered in detail.

The Suez Canal, across the narrow low-lying neck of land between the Mediterranean and the Red Sea, which links Africa to Asia, 
was mooted many centuries ago and actually begun about 1300 B.C., but the modern canal dates from 1869. The total length from Port Said to Port Ibrahim, by Suez, is 87

The Suez Canal miles of which 66 are actual canal, the rest being a dredged passage through several lakes. The canal is at sea-level throughout and there are no locks. Vessels pass along under their own steam at about 4 knots. The depth is now $36 \mathrm{ft}$. practically throughout, and the width sufficient to allow two vessels to pass one another in almost any part of the canal.

In 1914 the total number of vessels which made use of the Suez Canal was 4,802 with a tonnage of $19,500,000$. In 1913 , before trade was affected by the war, the total of ships was 5,084 .

The Panama Canal is the only other ship canal on a scale comparable with the Suez Canal. After a chequered history during which valiant but unsuccessful attempts were

The Panama made by the French to dig a sea-level canal, the United States Government started operations in 1906 with a high-level canal. Its unostentatious opening in the autumn of 1914 marked the completion of the most colossal engineering undertaking of all time. It joins the Caribbean Sea with the Pacific Ocean across the isthmus of Panama-a length of only 50 miles from deep water to deep water, of which only 15 miles are at sea-level.

Seven miles from the Atlantic end vessels ascend the three Gatun locks to an elevation of $85 \mathrm{ft}$. above sea-level. At this level they pass along the dredged channel in the artificial Features of Gatun Lake. From the Gatun Lake the canal Panama Canal Construction passes through the Gaillard Cut in a mountain ridge $312 \mathrm{ft}$. high, and after $31 \frac{1}{2}$ miles at high level descends by three locks, the Pedro Miguel and the two Miraflores, to the Pacific stretch of 11 miles. The minimum depth of the canal is intended to be $41 \mathrm{ft}$. and the minimum width $300 \mathrm{ft}$. The immense locks are each 1,000 ft. long and $110 \mathrm{ft}$. wide. All the locks are doubled in order that passing vessels need suffer no delay. There is nothing in its construction to prevent the largest vessel afloat from passing through the Panama Canal. Considerable trouble has, however, been caused by the landslides in the Gaillard Cut, which at various times during the first two years of the canal's existence partially or completely stopped traffic. Water 
for the canal is obtained from the Chagres River, which is fed by the abundant tropical rainfall. By the construction of a great dam across the lower valley of this river the immense Gatun Lake was formed. This not only prevents destruction of the canal by the violent floods of this capricious river but ensures a plentiful supply of water for the high-level reaches of the canal. Excess of water in the lake can be drained off to the original lower Chagres valley by the spillway capable of passing 137,000 cubic $\mathrm{ft}$. a second. As a further safeguard the culverts of the locks can be made to discharge 170,000 cubic ft. a second. During the year 1917 the number of vessels which passed through the Parama Canal was 2,048 with a total tonnage of about 7,500,000 tons.

In the British Isles the most important ship canal is the Manchester Ship Canal, the completion of which, in 1894, after seven years'work, made Manchester a seaport for vessels Manchester up to 12,000 tons capacity. The canal is entered at Eastham from the Mersey and is $35 \frac{1}{2}$ miles in length. It is $28 \mathrm{ft}$. deep and has a minimum bottom width of $120 \mathrm{ft}$. There are five sets of locks, each lock being $600 \mathrm{ft}$. long. Steamship lines now connect Manchester with all parts of the world, and the total trade of the port in 1914 was nearly 5,500,000 tons; Manchester being the fourth port of the United Kingdom. Before the construction of the ship canal the trade of Manchester and district was dependent on the port of Liverpool or to a lesser extent, Hull. While Manchester hoped that the construction of its ship canal would enable it to trade more advantageously than via Liverpool, by eliminating rail transit in the import of raw cotton and the export of manufactured goods, Liverpool vicwed the undertaking with some apprehension. It seemed possible that some of Liverpool's oversea trade would be lost. Results to a great extent justified the hopes of Manchester but not the fears of Liverpool. The great proportion of raw cotton for the Manchestcr manufacturing area, and. of finished cotton tissues and cotton yarn still pass via the port of Liverpool, although large quantities of raw cotton arrive by steamer in Manchester. Probably Liverpool is as convenient a collecting centre for the cotton weaving towns as Manchester, but to some extent this is certainly an example of geographical momentum (p. 84). It takes some time for a new market to acquire the organization of an old market. Trade is 
not easily disturbed from its accustomed routine unless by changes more drastic than these.

The fourth important ship canal is the Kiel Canal. This canal runs across Holstein from Holtenau, near Kiel, to Brunsbüttel, on

The Kiel Canal the mouth of the Elbe, a distance of about 61 miles, thus saving the long detour round Denmark for vessels bound from the Baltic to the North Sea. It is $144 \mathrm{ft}$. wide at the bottom and $36 \mathrm{ft}$. deep, and has four locks at each end. The Kiel Canal was completed in 1895 and deepened and improved in 1914 with a view to the requirements of the German navy for whose use it was primarily built, as affording a short passage within German territory between the Baltic and North Seas. It is now open to the vessels of all nations.

Other ship canals have been mooted but none have yet taken shape. The Caledonian Canal, built nearly a century ago across the highlands of Scotland by Glenmore from

The Caledonian Inverness to Port William, was originally intended
Canal for sea-going ships in order to obviate the long and stormy passage round Cape Wrath and the Pentland Firth. But its average depth of $18 \mathrm{ft}$. renders it useless for modern vessels of any size. Fishing boats and small coasting vessels can alone make use of it. The canal between the Forth and Clyde is older still. It has, however, been suggested to build a new Forth and Clyde canal suitable for large vessels from Grangemouth via Stirling to Loch Lomond and thence with two exits, one by the Vale of Leven to Dumbarton and the other by Arrochar to Loch Long. No progress has yet been made with the scheme but the construction of a great naval base at Rosyth empliasizes the high strategic value of such a canal.

\section{OCEAN TRANSPORT}

The cheapest and most satisfactory means of communication is by sea-going vessels. The cost is solely in the construction and working of the vessel. The road incurs no expense and is free to all, though navigation in coastal waters requires lighthouses, lightships, beacons, and pilots, to say nothing of the necessity of harbour facilities to safeguard vessels and to expedite and cheapen the handling of cargoes. The fact that the long highways of the open ocean are supplied ready for use and sometimes, that is in the 
case of sailing ships, the motive power is furnished by Nature, gives ocean transport a cheapness out of all proportion to land transport.

Oceans are no longer barriers as they were in the earlier days of civilization: they are links between countries, and the more

Ocean

Highways and

National

Advancement advanced the progress of any people the greater advantage do they take of the ocean highway. Those countries with a long and easily accessible seaboard, that is accessible both externally and internally, are the more advantageously placed in developing trade.

In another chapter (XV) the origin and develcpment of lorg distance sea commerce is traced. It is shown how seamanship gradually improved and vessels increased in size as first the Mediterranean and later the open ocean came to be used by traders.

Until the nineteenth century all ocean navigation was by sailing ships. They seldom attained a size of over 600 to 700 tons : a sailing ship of 1,500 to 2,000 tons is still considered

Sailing Ships a large vessel. The largest ever built was probably the Preussen, of 5,000 tons, which was lost by collision a few years ago.

About 1840 iron began to replace wood and later steel was used in the construction of sailing ships : auxiliary motors are sometimes installed. The speed of a sailing ship depends on the force of the wind and the skill with which the ship is handled. Ten, twelve, or even fifteen knots may be attained. Calms and light winds cause protracted passages. The competition between Britain and America for the China tea trade in the fifties and sixties of last century led to the construction of fast sailing ships, known as clippers, among which some Aberdeen vessels were famous for their speed. The Thermopylae ran from London to Melbourne in sixty-three days. At a slightly earlier date many American clippers were built in response to the rush for the goldfields of California : they competed also in the tea trade.

Sailing vessels nowadays generally carry cargoes which are cheap in proportion to their bulk and for which there is no immediate hurry. Grain, coal, nitrate, timber, and ice are typical cargoes. While large sailing ships are decreasing in number year by year they will probably remain on certain routes (Chapter XVII). The majority of deep-water sailing ships are now owned in Norway, which is a country where conditions have always promoted seafaring. 
Early in the nineteenth century steam-power began to be utilized on vessels, first as an auxiliary to sail and later as the sole motive power. It is curious to note how the masts and Steamships spars of the ship persisted on the steamer long after the use of sails had practically been abandoned and the graceful clipper bow of the sailing ship only recently gave way to the forceful square bluff bows of the modern steamer, more economical of carrying space but undeniably ugly.

Screw steamers soon replaced paddle boats, and during the last century there have been continuous developments in marine engines, with a view to increasing the initial pressure of the steam and fuller utilization of the heat. Single cylinders were followed by compound engines and then various forms of turbines were introduced. Internal combustion engines are now used in some large steamers. The size and speed of vessels have continually increased since the early days when the paddle steamer Great Western, $230 \mathrm{ft}$. long, took fifteen days to cross the Atlantic. The Mauretania, which is $762 \mathrm{ft}$. long and has a tonnage of 31,938 tons, can cross in four and a-half days. The largest steamers, which were originally German, are the Imperator of 51,969 tons, and with a length of $882 \mathrm{ft}$., the Leviathan (late Vaterland) of 54,282 tons and $907 \mathrm{ft}$. long, and the Bismarck of 56,000 tons and $912 \mathrm{ft}$. in length. The Olympic of 46,359 tons, with a length of $883 \mathrm{ft}$., is the largest British-built ship. These huge vessels are not constructed for exceptional speed. The average cargo steamer varies from 1,000 to 6,000 tons, and has a speed of 9 to 10 knots.

Steamships being largely indifferent to wind and weather, take the shortest route from port to port. Only the worst weather

Steamship Routes seriously interferes with a full-powered modern steamship. Calm and adverse winds do not detain them. Where possible steamships generally follow great circle routes.

A great circle route is the arc of a circle whose centre is the centre of the earth. It is therefore the shortest distance between any two points on the surface of the globe. All meridians being the arcs of great circles, the shortest north and south route is always along a meridian. Parallels of latitude, except the equator, are not great circles. In consequence for east and west courses a great circle route is represented by a curved line to the poleward side of 
a parallel. The higher the latitude the greater is the departure from the parallel.

Regular liners follow certain charted routes slightly different for outward and homeward courses in order to reduce the chance of collision and at the same time to ensure the prospect of help in case of accident.

The size of steamships is decided by their trade and the route on which they are employed. The largest vessels are the great liners on the North Atlantic routes between Atlantic Europe and America on which speed, combined with luxurious passerger accommcdation, is demanded. The largest vessels in this trade require special harbour facilities and are not easy to handle in a confincd space. For this reason trans-Atlantic liners some years ago abandoned their former call at Qucenstown, Ireland, and recently several of the largest have changed their British port from Liverpocl to Southampton. Increase in the size of steamers necessitatcs the dredging of many harbours and estuaries and lcads in several cases to the construction of outports (p. 160). The Panama Canal is deep and wide enough even in its locks, to admit the largest ships afloat, but the Suez Canal, when it was only $30 \mathrm{ft}$. in depth, used to restrict the size of steamers in the eastern trade. Considerations such as these change the geographical value of ports and routes from time to time. The larger the vessel the fewer ports can it enter and the more restricted the range of its activities. On these grounds alone there are limits to the size of the average " tramp."

At the same time it pays to carry goods in as large a vessel as possible provided it can be filled. This reduces the freight of the cargo per ton. And since, first, it is costly to

Cheapness of

Sea Transit break bulk, that is, transfer from one means of transit to another of the same or different kind, and, secondly, sea transit is always chcaper than land, it pays to carry bulky cargoes occupying a whole vessel to the port nearest to their destination. Hence such commodities go to many small ports while the more valuable, less bulky commodities arrive in large vessels, as parts of a general cargo at large ports.

Special kinds of steamers are built for particular cargoes. Mention has already been made of shallow draught steamers for canals and rivers. Vessels fitted with tanks and with engine room in the 
stern are used to carry petroleum in bulk. Ore carriers are built with large hatches and holds and various devices for speedy loading and unloading. Vessels with refrigerating installations carry frozen and chilled meat. On some routes in the Baltic and on the great lakes of North America train ferries carry part or the whole of a train on board from one shore to the other. During the European war a train ferry, which could carry 54 10-ton trucks, ran across the English Channel between Richborough and Dunkirk, Calais and Boulogne. Lastly, the specialized vessels used as icebreakers should be noted: they have geographical importance in keeping open during winter, or part of the winter, seaports which would otherwise be closed by ice. In the Baltic, White Sea, St. Lawrence, and North American lakes they are much used: there are icebreakers on Lake Baikal in Siberia.

A steamer must have coaling stations along its track: their distribution to some extent determines routes. It is for this reason that many small islands like St. Vincent in the Coaling Stations Cape Verdes, Las Palmas in the Canaries, or Perim in the Red Sea have considerable importance. The opening of the Panama Canal may give rise to new coaling stations in the wide Pacific.

In number of seagoing vessels and total mercantile tonnage the United Kingdom has long had the lead, but loss of vessels by enemy action from 1914 to 1919 , as well as great shipThe World's building activity in the United States have con-
Merchant

Tonnage siderably decreased our mercantile ascendency. During the war no less than 2,479 British merchant ships of a total tonnage of $7,759,000$ were lost by enemy action.

The following figures give the approximate merchant tonnage, in millions of tons, of the principal ship-owning countries before and after the war. The great increase in American tonnage is the most noticeable.

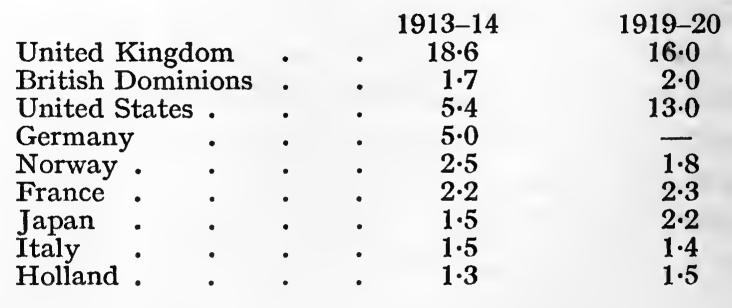


Accurate post-war figures for Germany are not available, but by the Treaty of Versailles all tonnage over 1,600 tons was handed over to the Allies. The total will considerably increase during the next few years and the relative position of different countries may change. Britain, Canada, the United States, France, Holland, Italy, and Japan are showing great activity in their shipyards, but unless the rate of British ship-building considerably increases Britain's lead will not be maintained.

\section{AERIAL TRANSPORT}

Air transit is the latest phase in the history of transport. The development of aeroplanes and airships, and skill in their manipulation, made great strides during the European

Aerial

Transport war, but the science of aviation is still in its early stages. Two types of air vessels must be distinguished. The airship relies on the use of a large volume of gas to give it buoyancy and so is lighter than air. The aeroplane has no gas container and is heavier than air. So far progress has been made chiefly in the use of the aeroplane which can now be flown more or less independently of weather conditions and with comparatively little risk of accidents. For trade purposes the aeroplane is unlikely to be of use because of its small capacity for cargo, which is further diminished when large quantities of petrol are carried. However, for the rapid transit of passengers and mails the success of flying is assured. A daily service takes four hours between Paris and London including land transit to and from the aerodromes on the outskirts of both towns.

It is estimated by experts that the air route between London and Sydney should be covered in six stages of a day each at a speed of 100 miles an hour by an aeroplane carrying sixteen passengers or one ton of mails. The provision of suitable aerodromes and landing places exercise a certain geographical control over the course of air route.

\section{POSTS, TELEGRAPHS AND LANGUAGES}

Postal and telegraphic facilities have developed in response to the demands of trade, and have done much to bring into close relations lands widely apart in distance. The introduction of penny 
postage within the United Kingdom in 1840, the formation of the Universal Postal Union in 1874 (to facilitate and unify as far as possible the systems between and in various

Universal

Postal Union countries) and the institution of Imperial Penny

Postage in. 1899 were great landmarks in postal communication. The European war caused many facilities to be withdrawn and postage rates to be considerably increased.

All countries in the world now belong to the Universal Postal Union and the only inhabited lands with which there is no communication are the remoter parts of northern Siberia, Tibet, and central Asia, and the Sahara and inner Arabia. Most countries pay considerable subsidies to various steamship lines to carry mails on condition that regular services and fixed times are maintained. Mails also go by other lines at poundage rates.

The electric telegraph came into general use less than a century ago. It is now used in all civilized countries. The first submarine cable was laid across the North Atlantic in 1866.

Electric

Telegraph Since then cables have multiplied to such an extent that practically all lands are linked by telegraph. Various isolated oceanic islands like Ascension in the Atlantic, Cocos in the Indian and Fanning in the Pacific Ocean, have come into prominence and been put into direct relationship with the busy world as relay stations for submarine cables.

Wireless telegraphy has probably made greater strides than any other modern invention. It was only in 1902 that wireless communication was established across the Atlantic,

Wireless

Telegraphy and now there are high-power wireless stations throughout the world. There being no expensive cables to lay and keep in repair, wireless telegraphy can compete successfully with ordinary telegraphs. It is doubtful if any more submarine cables will be laid as the rate of transmission by wireless is considerably cheaper. The installation of wireless on vessels has been invaluable if only in ensuring safety in case of accident.

The telephone is mainly used for short distance communication, but long distance telephony is possible. It is in Scandinavian countries and the United States that the telephone

Telephone is in most extensive use. In Great Britain the system is less widespread and has much deteriorated since it was nationalized some years ago. 
The distribution of various languages in commerce is of much importance. While English is most widely spoken, owing to the cxtent of the Empire and even more to the preLanguages valence of British shipping, it is by no means of universal value. Spanish is the language of all tropical and South America except Brazil, where Portuguese is spoken. In northern Africa, ircluding the Sudan, Red Sea, and Persian Gulf and East African ports, Arabic is a necessary language for commerce. French and German are of relatively little use outside Europe, and Russian is spoken only in Russia and Siberia, but in both these lands it is essential. In India a form of crude Hindustani is the lingua franca, but English is known by the educated classes.

In Pacific lands there are two bastard tongues known respectively as pigeon English and bêche-de-mer English which have a wide vogue. Pigeon English is a lingua franca between Europeans and Chinese labourers while bêche-de-mer English is used in the islands of the south-western Pacific. 


\section{CHAPTER XV}

\section{THE DEVELOPMENT AND COURSE OF TRADE}

\section{BARTER AND EARLY TRADE}

TRADE is the result of the unequal distribution of commodities depending on different conditions of soil and climate and the occurrence of different minerals. Every community lacks certain things and can produce a surplus of others.

The shepherd has an abundance of skins, wool, and woollen cloth, but is in want of corn, which the peasant who is in need of wool, has in quantity. Both may lack salt of which Barter the coastal fisher folk have an abundant supply. From this inequality in the distribution of necessities, or it may be luxuries, arose barter, a form of direct exchange which still obtains among primitive folk. Trade with remote and isolated people even partakes of this nature. The Eskimo has an abundance of bear and fox skins. On the other hand he desires knives, needles, and many simple manufactured articles. The whalers used to barter a bear skin for a knife, or a few packets of needles. Both were content, for Eskimo and whaler had each got what he wanted in exchange for something of considerably less value to him. But nowadays the Eskimo have learnt that the white man values a few skins far higher than a knife or a small looking-glass, and they demand more in exchange for their skins. Time was when in Africa a trader could purchase a pair of elephant tusks for a few glass beads, or when in Lower Burma the primitive pearl fishers would barter a large pearl for half-a-dozen red cotton handkerchiefs or a few pounds of rice. That sort of trade, so lucrative to the white man, is nearly over ; even the most primitive people are learning what the white man values and how much he values it. If a certain sense of conscience stopped the practice of bartering bad gin for valuable native produce, and a sense of self-defence put an end to the sale of firearms, even inefficient ones, the native himself bade fair to stop the practice by demanding more than the white man chose to give.

Articles of trade are often bartered from one tribe to another and so filter through long distances, in the end reaching a people 
of whom the originators never heard, or with whom, at any rate, they have had no personal contact. Siberian products-skins, jade, and metal-take an average of five years to reach the Eskimo of Baffin Land in this way. In like manner tobacco reached the remotest parts of Africa ahead of Europeans.

The Phoenicians, who were the earliest maritime people in the Mediterranean, carried this type of unequal barter a step further. For theirs was not a frontier but a long distance The Phoenicians trade. They went by sea in search of the primitive folk with whom to exchange commodities. The Phoenicians had manufactured articles of metal, linen, wool, and glass, beside products of India, dyes, drugs, and silks, to barter with the peoples of the western Mediterrancan and Atlantic seaboard. In return they obtained metallic ores and grain-at Phoenician valuation, and so the road to wealth was quick and easy.

The "colonies" of the Phoenicians were merely trading stations and generally on defensible positions (e.g., Gades = Cadiz), secure against attack from land and easily accessible Phoenician from the sea. Carthage grew to be the greatest
Colonies and most wealthy. Its position favoured it as the link between eastern and western Mediterranean in close touch with the trade of Africa and the fertile Barbary States. The strategic value of the site of Carthage in the past finds its modern counterpart in the situation of the French naval base of Bizerta, a little further south on the same coast, or in our own possession of Malta as one of the keys to the command of the Mediterranean route.

The development of overland trade is another type of long distance commerce. The earliest overland traders were pastoral people: the geographical conditions that induce Development the pastoral life generally favouring commercial Trade enterprize. A pastoral people by virtue of their occupation are nomadic, and the poorer the grasslands the more the people must wander. This nomadic life brings them into contact with settled agricultural peoples on the richer borderlands or in the productive oases where springs give fertility to the steppes or deserts. And thus a pastoral people become carriers of commodities from one distant tribe to another. 
Their inducement to trade depends on the productivity of the borderlands, while their ability to carry on a successful trade is largely determined by the beast of burden they possess. The Arabs are the best example of long distance overland traders. In Arabia and the Sahara they instituted an overland trade that still persists and probably will always continue to do so. This trade most likely originated in carrying salt from the Sudan and Barbary States to the desert oases where there are no local supplies. But it rapidly developed into a trade in ivory, gold, spices, skins, and ostrich feathers which reached the Mediterranean from tropical Africa, in return for cloth and metal, and from the seventeenth century onwards, tobacco.

The Arabs employed as a.beast of burden the camel, which they brought with them from Arabia into Africa. To-day the trade across the Sahara is still dependent on camel caravans and there is little likelihood of railways displacing them. The caravan is certainly the only possible means of reaching the scattered oases. The produce of Turkestan still reaches India in camel caravans which arrive every season at Peshawar from the north.

It is not improbable that raids on more settled, and consequently more prosperous people, who are a tempting prey to nomads, helped to suggest to the Arab the possibilities of

Arab Trade trade, and especially the slave trade. Of all commodities of commerce the negro slave proved the most lucrative to the Arab. This was not the beginning of the slave trade: for it probably started with the Egyptians raiding slaves in the Sudan. But it was the Arabs who pushed the ramifications of the slave trade into the remotest parts of Africa. Most of the Mediterranean lands bought negroes: they were in demand in Turkish harems and were sold in Arabia, Persia, and India. Throughout the Mediterranean pericd in civilization the Arabs finding a steady demand for slaves retained the trade in their hands. Slaves materially assisted the transport of goods across the Sahara and proved economical since they cost little and could be sold for a high price at the journey's end. The stoppage of slavery in the nineteenth century seriously curtailed the trans-Sahara trade. Further aspects of the slave trade are discussed later (p. 149). 


\section{TRADE WITH THE EAST}

The trade with the East, promoted by the Phocnicians, persisted in the Mediterranean. The richest products of India, Malaya, and

China reached the civilized lands of the Mediter-

Eastern

Trado

ranean either via the Red Sea or through Mesopotamia. The whole history of Mediterranean civilization is intimately bound up with that trade. It was essentially a trade in luxuries, for they alone could bear the heavy expenses of the long and laborious journey in small ships and caravans. Low valued articles, especially if of a bulky nature, would never pay the traders. The eastern ends of these routes to the Persian Gulf or the Red Sea were mainly in Arab hands. Caravans carried the goods up the Euphrates Valley and through Syria to Tyre and Sidon. Later the traffic went through Palmyra and Damascus to Egypt, or northward through the Cilician Gates and across Asia Minor to Constantinople, making that city for many centuries the great mart of the East. From the Red Sea the trade routes reached Cairo and Alexandria, or crossed the Isthmus of Suez. The destruction of Tyre and the foundation of Alexandria by Alexander the Great was the outcome of an attempt on the part of the Macedonians to divert this lucrative trade from Phoenicia.

As northern Syria was destined by geographical circumstances to be a centre for the Eastern trade, and the Phoenicians to be middlemen between east and west, so the Greeks in their turn found themselves in conditions scarcely less advantageous.

The factors which made the Greeks a maritime nation are most obvious; abundant harbours, land-locked island-studded waters of the Aegean Sea and all the Mediterranean Greek Trading inducements to seamanship, with, on the other
Stations hand, a relatively infertile hinterland, or at any rate one in which fertility is localized in the valleys. While Phoenician influence was felt along the southern shores of the Mediterranean, the Greeks established their trading stations along the northern coasts and in the Black Sea. They werc to be found in Asia Minor, Crete, Cyprus, Cyrenaica, Sicily, southern Italy and as far west as the plains at the mouth of the Rhone where Massilia was the origin of modern Marseilles. Byzantium (modern Constantinople) was the most important of all. 
In these days practically all Europe's long distance trade was with the East. Northern Europe was an unknown region of barbarians from which only a little Baltic amber reached the Mediterranean or filtered through to the East.

It was under the Romans that an oversea trade in necessaries, in contrast to luxuries, first began. The urban population outgrew the production, potential or actual, of the region Roman around Rome and the importation of food was Trade necessary. They imported grain from Sicily from the Barbary States, and from Egypt to Rome.

But in the days of the Mediterranean era of civilization the long distance trade - and that is the trade of geographical importancewas essentially one in luxuries. As the population grew in numbers and wealth this demand increased. In modern times the trade has undergone changes in nature and in route but it still remains one of the most important to Europe.

Early Mediterranean seamen scarcely ventured out of sight of land. They navigated their ships by landmarks. Not only were their vessels somewhat inadequate for bad weather

Early

Maritime

Trade away from the shelter of a harbour, but the seamen had no means of finding their way back when once they passed out of sight of land. Probably the compass was not introduced into Europe until the twelfth century. These early navigators avoided sailing by night whenever possible, and anchored their vessels during the darkness. Thus there were difficulties in the way of maritime trade that are not easy to appreciate nowadays. Physical considerations had more control than they have at present. But gradually as man acquired greater skill in shipbuilding and greater knowledge of navigation he boldly ventured forth across the seas, steering by the stars and sun, and so was enabled to push into the remoter western parts of the Mediterranean. It was no longer necessary to hug the coast. Ships went further, routes were more direct, and voyages quicker.

All through the Middle Ages the trade with the East remained the most important in Europe. A little of it passed overland. There were trade routes north of the Caspian Sea and across Russia to the Danube Valley or to Baltic Europe, but most of it reached the Mediterranean seaboard first on its way to the 
West. It still continued to be a trade in luxuries : silks, spices, drugs, jewels, and perfumes remained the commodities of commerce. Spices, especially, were in extraordinary demand the Middle Ages

ity, and especially that of pepper, was doubtless due to the general use of dried and salted meat, tasteless or unpalatable as they both are.

This particular phase of Mediterranean trade reached its height in the hands of the seamen of Venice and Genoa. Other great

\section{Mediterranean Trade}

trading centres arose in the western Mediterranean such as Pisa and Florence, but they were never the equals of the two first named. Venice is singularly well situated as an emporium of trade and a distributing centre for Europe, and her central position in the Mediterranean was more in her favour in the world of the Middle Ages than it is to-day, when the development of the West has changed the focus of Europe.

Situated amid the lagoons that fringe the Adriatic coast of Lombardy and protected by a natural storm-beach from the sea, Venice grew in a position that was not only

The Rise of Venice defensible from land attacks but was admirably suited, in fact inevitably destined, for expansion by sea. In the comparative peace that her secure position afforded her Venice was enabled to develop rapidly finding many customers in the mainland and through the Alpine passes in northern and western Europe. It was only when hostilities threatened to control the passes that Venice began to extend her territory. The Venetians fetched the Eastern produce from Levantine ports and Alexandria to Venice whither came the people who sought it. In return the Venetians took East corals, oil, wine, silver and other metals. Venice grew rich and developed manufactures of her own, favoured by the prosperity of her citizens. Venetian glass, lace, armour, leather, cordage, soap, and goldsmith work became famous. The effect of this prosperity derived from the East is most noticeable in the Oriental atmosphere in the buildings of Venice. The cathedral of St. Marks, lavishly decorated with gorgeous stones and marbles, is bright in colour but incongruous in scheme. It is a museum of Eastern splendour to which the Venetians brought all the best and most beautiful they could find. Its architecture is largely Eastern 
and suggests a Mohammedan mosque rather than a Cluristian cathedral. Even the bones of the patron saint of St. Marks were "looted" from Alexandria. The hold that Venice had for three centuries on the Ionian Islands was the outcome of this ascendancy in the eastern Mediterrancan. An echo of her greatness is heard to-day in Italy's claim to a share of Asia Minor.

Genoa and other cities on the west of the Italian peninsula were never so well placed for trade with Levantine ports. The distance was greater and they had less easy access with the rest of Europe.

\section{OCEANIC PERIOD}

The great blow to the Mediterranean trade was the discovery of the sea route to India in 1498. Geography is not largely concerned with dates but the year of that discovery was

Discovery of Sea Route to India important. Not less so was the year 1453 in which the Turks seized Constantinople, soon after which the trade routes across Syria fell into their

hands. It was this occurrence and a sense of envy for the virtual monopoly of Venice that stimulatcd Portugal to seek a new and independent route to the East.

The geographical position of Portugal destined that country to take the lead in oceanic navigation. Civilization by this time

Portuguese

Seamanship had spread almost throughout Europe. Portugal was near to Mediterranean influences but somewhat cut off from the rest of Europe. The Portuguese learnt their seamanship in the sterner waters of the Atlantic and were seamen of no mean ability. The natural line of Portuguese expansion was over the ocean. No doubt their proximity to Africa and their foothold on the ccast of Morocco had taught the Portuguese something of the trade of the Gold Coast and tropical lands. Europeans had traded with West Africa at an earlier date, for the Normans had stations on the Guinea coast in the fourteenth century.

The early Portuguese voyagers hugged the African coast fearing to be far out of sight of land. Year by year their progress was marked by new trading stations on the African coast. Some of these were little more than resting places for watering and provisioning, but they did a lucrative trade in gold, ivory and slaves. 
In 1487 Bartholomew Diaz reached Algoa Bay and in 1498 Vasco da Gama rounded the Cape of Good Hope, and steered across the Indian Ocean from near Mombasa to Calicut in India. The sea route to the East was discovered and the trade of the East began to pour into Lisbon: Venice soon suffered decline.

Every year fleets of several ships left Portugal for India and frequently went on to Cochin to complete their loading for Lisbon.

Compared with modern ships they were small, probably only 200 to 400 tons, so that the total freight that reached Lisbon every year was not more than about 2,000 tons. In time these ships grew somewhat larger and were less encumbered with fighting men. This not only enabled them to carry more produce but increased their capacity for food and water and so diminished the numbers of calls on the road. Moreover, as the terrors of the tropics were overcome and greater confidence gained in the ocean, the fleets ceasing to hug the shore sailed more direct, thus gaining time and reducing the number of vessels lost by wreck. Among the trade commodities of this period were pepper, cloves, nutmegs, ginger and maces, sapphires, rubies, pearls, diamonds, musk, and various drugs. In return for these valuable commodities the Portuguese took to the East coral, lead, silver, copper, quicksilver, alum and other goods.

The Portuguese went beyond India in their search for trade and reachcd the Malay Archipelago and China, and they practically ousted the Arabs from the trade in the Persian

Portuguese Trading Stations Gulf. A few of their trading stations in the East still remain in Portuguese possession, as Diu and Goa in India, Timor in Malaya and Macao in China. They are reminiscent of Portugal's great past. Like the Phoenicians in the Mediterranean the Portuguese in the East placed their trading stations on defensible spots like islands.

When once the route to the East was discovered-the real objective of the Portuguese mariners-most of the African trading ports were neglected except those connected with the slave trade. The majority ultimately passed into other hands, and had it not been for Portugal's interest in the slave trade she would probably have no African possessions to-day. Those that she has, Guinea, Angola, and Mozambique, are but little developed. Portugal's power in the days of its greatness was built on trade and not on 10-(1909) 
territorial acquisition to which she did not aspire. Portuguese influence along the African coast and in islands on the route to the East is evident in many place names not to speak of racial admixture. Portugal's foothold in South America was an outcome of her Eastern trade The north-east trade winds and the equatorial current carried Cabral too far east on his road to India and led to the discovery of Brazil. In the whole of South America Brazil is the only land which is Portuguese in history, language and tradition, although it has long been independent of Portuguese rule.

Lisbon, on the outer edge of Europe, was never a good distributing centre and could not compare with sites on the mouths of the Scheldt, Meuse, or Rhine. Dutch vessels were in the habit of coming to Lisbon to fetch Eastern produce for the lands of northern Europe. In time they went east to the source of the trade. No doubt the activity of the Dutch was also stimulated by the mportant woollen manufactures of the Netherlands.

The Dutch followed the Portuguese as masters of the Eastern trade. The Netherlands with their fertile soil, and central position, had a population prosperous in agriculture,

The Duteh and Eastern Trade manufactures, and trade, while the Zuyder Zee and the mouths of the Rhine were conducive to the development of maritime interests. The Dutch passed first to Malaya, China, and Formosa but also frequented Ceylon. Ships had grown larger, the journey safer, and ports of call less necessary so that Dutch influence in Africa, arising out of this trade, was confined to the extreme south where Table Bay was a port of call and later the site of a settlement. From Ceylon they brought cinnamon and from Malaya pepper, spices, pearls, and coffec. Dutch influence in the East is recalled by the present extensive possessions of Holland in the Malay Archipelago, including the Celebes or Spice Islands.

Following the Dutch, other nations followed the Cape route to the East in search of trade. The result of the French enterprise in this direction was the acquisition of much territoty in India of which now merely a few towns remain, Pondicherri, Karikal, Yanan, Mahé, and a small suburb of Calcutta, Chandernagore.

The French acquisition in Indo-China, though of a much later date, were really inspired by similar motives, and so was the earlier French possession of the Seychelles, Rodrigues, Mauritius, and 
Madagascar. The interests of France in Africa did not originate in their Eastern trade but were the outcome of independent endeavours. ${ }^{1}$

Britain, on her entry into the Eastern trade, became a rival to the French interests and rapidly assumed a position of great importance. Surat, on the Gulf of Cambay on Eariy British the west coast of India was the earliest British Trading

Ports trading port, but Madras on the Bay of Bengal soon eclipsed it as having easier access to a larger hinterland. Calcutta, the cxit of the rich Ganges Valley, attained chief importance in time and became the capital, administrative and commercial. It must be remembered that in these days the only route from Britain to Calcutta was round the Cape of Gccd Hope, and for a sailing ship by that route ports in the Bay of Bengal were as near as those on the Arabian Sea. The effect of the re-opening of the Mcditerranean route by the digging of the Suez Canal will be noted later.

Spain's share in the Eastern trade has still to be considered for it had important and far-reaching geographical results. A Genoese

Discovery of seaman, Christopher Columbus, who had made America
voyages in Portuguese ships along the African coast, came to the belief that the shortest route to Cathay (China) and Cipango (Japan) was westward across the Atlantic. From the Canaries to Cipango he put the distance at 2,500 miles. Of course in these days the existence of America was undreamt of, for the early Norse discovery of that continent had been completely forgotten probably because it had resulted only in the discovery of infertile and uninviting lands. And so it was once again the lure of the Eastern trade that drew Europe westward and resulted in the discovery of America by Columbus with a Spanish fleet in 1492. The feat of sailing west into the unknown was no mean undertaking. The largest ship was one $90 \mathrm{ft}$. long by $20 \mathrm{ft}$. broad, and the other two were only half-decked and of smaller size. The landfall was one of the small islands of the Bahama group whence Columbus believed the great cities of Asia were ten days sail to the west. This discovery was followed rapidly by others, and gradually the whole of the West Indies and tropical America

1 Most nations in Europe took part in the trade with Africa, especially the Guinea coast, but the object of this chapter is to trace the effect of the Eastern trade and not to give a history of Africa. 
became known, the term "Indies" and that of "Indians" being misnomers applied in the belief that India had been reached by a new route. A new trade, but still largely in luxuries, set in to Spain; drugs, logwood, sugar, and precious metals could all be carried in small ships in sufficient quantities to yield a profit on the voyage. Yet it was the quest of precious metals rather than trade which held Spanish interests in America.

The search for a route to the East-when once it was realized that the Americas stood in the way-carried Spanish
Exploration Spanish explorations down the south of South America and ultimately led to Magellan's voyage (1519) through the strait that now bears his name, into the Pacific Ocean.

Meanwhile, however, and for long after the Spanish overran tropical and South America in the search for wealth, trading stations grew up at Vera Cruz, Puerto Bello, Spanish
Acapulco, Buenos Aires, and a host of other

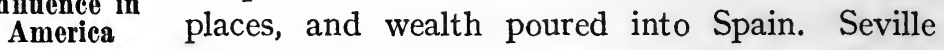
was the port that had most of the trade with America. Its position at the head of the westward flowing navigable Guadalquiver in the heart of fertile, wealthy Andalusia marked it out for this function. Throughout Central and South America, except in Portuguese Brazil, Spain's influence was everywhere and has remained to this day. The people, the language, the customs, the place names are all Spanish and independence is nowhere more than about a century old. In the West Indies Spain's power lingered till the United States took the last of her possessions, Cuba and Puerto Rico, in 1899. The growth of Spanish interests in America to these dimensions did not deter Spain from her ambition of reaching the East. Magellan's voyage paved the way for Spanish trade and power in the Pacific. Although her possessions have now all gone, sold or ceded to other powers, her territory and influence were great until recent years.

In Africa, apart from the north-west corner near to Spain, Spanish interests and influence were always of small concern. In the days of the great voyages Spain took the American and Portugal the African route to the East. They kept to their respective spheres into which the Pope Alexander VI with sublime arrogance had seen fit in $\mathbf{1 4 9 4}$ to divide the globe. 
It is worth noting that the Portuguese and Spaniards did more than discover two new roads to the East and bring new lands to the world's knowledge. Important as these dis-

Effects of Oceanic Seaboard coveries were they were of small account compared with the realization that the oceans are not separated but are all linked together-a discovery which led to the occan becoming the chief highway of the world, the transference of power and importance from the Mediterranean to the oceanic seaboard, and the rise of empire based on control of the oceans.

\section{THE SLAVE TRADE}

European intercourse with Africa and the development of America led to an expansion of the slave trade. It has already been shown that this trade was as old as civilization, but it was not until the Portuguese began to visit West Africa that the Arabs had any serious competitors. Then developed a wider aspect of the trade, which had far-reaching geographical results.

The economic causes which led to the slave trade are discussed elsewhere (p. 95) : some of its geographical effects must be noted.

In the early years of the sixteenth century Span-

Geographical Effects of Slave Trade iards landed the first cargo of slaves in America, at Hispaniola. They came from Portuguese trading stations in Africa and were destined for plantation work in America. Before this, however, the Portuguese had brought slaves to Lisbon where some 10,000 were sold annually during the sixteenth century. For a considerable time after its discovery by the Portuguese no slaves were carried to Brazil but they were at length introduced to work the gold mines of Minas Geraes. Slaves poured into America from the sixteenth to the ninetcenth centuries. In Mexico and Peru the Spaniards required them for their mines, in Cuba and other West Indian islands they demanded them for the sugar plantations. From 1790 to 1820 nearly a quarter of a million African negroes were landed in Cuba, and as late as the years $1845-1855$ some 55,000 arrived.

The population of Jamaica is mainly negro to-day while Haiti and San Domingo are negro states where the Africans, throwing over their French and Spanish masters, proclaimed their independence. The slave trade was first in Spanish hands but when 
England started tobacco plantations in Jamaica and other West Indian islands she soon outdid Spain and her demand was greater than the Spanish. In the English colonies in Negro
population $\begin{aligned} & \text { North America slavery was practised from an } \\ & \text { carly date and persisted in the south until } 1862 .\end{aligned}$ Here cotton, sugar, and tobacco plantations absorbed the slaves. It has been calculated that from 1680 to 1780 about $1,250,000$ African slaves were imported to English American colonies alone.

In the United States to-day there are about $10,000,000$ negroes, or about one negro to every eight white men. Sir Harry Johnston has calculated that in North America, Central America, the West Indies, and Brazil there are now over 24,000,000 negroes.

To supply the demand for slaves Portugal maintained many trading stations on the coasts of tropical Africa. It has alrcady been pointed out that but for the slave trade many of the ports of call of Portugal, on her eastern road, would have been abandoned. All these stations were in tropical regions where the supply of negroes was abundant and many of them were posts previously held by Arabs for the same purpose.

The early slaves brought to America by the English came from the neighbourhood of the Gambia River, and that is how Gambia is the oldest British dependency in Africa. Few rivers on the African coast afford an entry to the land but the Gambia is an exception. Over a wide bar that can be crossed at all tides the slaver could ascend 200 miles into an open forest and savannah country which tapped the Sudan with its dense population of peaceful agricultural negroes. About the Niger delta was another rich area. But in the main the savannah lands were most productive of slaves and the impenetrable and sparsely populated forests least so, except along the rivers which formed the natural highways into the interior.

In the eighteenth century and late in the seventeenth, the African slave trade was at its height. The lines of export to the West Indies and North America were from Guinea Mfrican including what is now Sierra Lcone, the Gold and
Slave Trade Slave coasts, and the Niger mouths, and to a less extent from the Zambesi region. To Spanish Central America the slaves came from Corisco Bay in the Bight of Biafra, the only 
Spanish possession in tropical Africa to-day; and to Brazil from the Congo, Angola, Mozambique, and Portuguese Guinea-all Portuguese possessions to-day.

- Early in the nineteenth century the oversea slave trade ceased. In 1830 Britain paid Portugal a large sum to prohibit the export of slaves from any Portuguese possession, but it was fifty years later before it ceased in Brazil, and all that time occasional cargocs of negroes were run across. Once the trade was prohibited it became more lucrative than ever. The horrors of the "middle passage," as the voyage across the Atlantic was called, nevcr reached their worst until the negroes were smuggled.

The slave trade, even within the boundaries of Africa, is now extinct, but persisted in some parts of the Sudan as late as the beginning of this century.

The effect of the slave trade on. Africa was considerable. The influence of the slave raider went far beyond his footsteps and induced raids and enslavement on the part of African
Slave Raiders tribes who know little or nothing of the raiders themselves and merely understood that somewhere far away there was a market for men and women. Certainly slavery did much to perpetuate, and in cases, to initiate savagery in negro Africa, and to despoil it of population and so retard its development. And if Arab influence missed any region, Portuguese probably touched it, for after the Arabs the Portugucse were the principal slave raiders in Africa, even if the English excelled them in enterprise and, sad to relate, in cruclty. But there is another side to the picture. The Arab, and later the Portuguese, acquired a great deal of knowledge of the heart of Africa. The Phoenicians may have learnt of the sea south of Africa from Arabs, and it was from Arabs that Ptolemy learnt the truth about the sources of the Nile.

The influence of both Arab and Portuguese is found in the far interior. Yet little of what they knew survived, for little was put on record. To divulge the more fruitful slave areas was to defeat the aim of the slaver and so many an Arab and Portuguese kept his knowledge to himself. There are, however, old maps of Africa prepared by Portuguese which show topographical features in the far interior about the great lakes and the Congo, which were forgotten and not rediscovered till two centuries later. 
The Arabs introduced some useful crops to tropical Africa (see p. 23), and also the horse. The Portuguese gave Africa, in addition to many vegetable products, the pig and turkey, and several breeds of cattle. So that even if they helped still further to decrease the negro population the Portuguese did some good to Africa.

Lastly, it might be noted that to the African slave trade is due the independent negro republic of Liberia in West Africa, which was formed for freed and repatriated American slaves.

Independent Maryland, another such settlement, was absorbed
Negro Republic in Liberia, and a third one, Sierra Leone, has become a dependency of Britain.

\section{NORTH-EAST AND NORTH-WEST PASSAGES}

To return again to Europe's trade with the East. While a route to Asia and its riches was being sought by the Spaniards through the islands they had discovered in the west (West

European Trade Indies) and later on round South America, the Engwith the East

lish were not idle. The British merchants dispatched Cabot, a Genoese by birth, and Venetian by adoption, on a voyage to the West in 1497. His discovery of Labrador, which he took for some land north-east of Asia, was really the beginning of the search for a north-west passage to the East.

And half a century later the expeditions sent by London merchants to seek a passage north of Asia for trade with China, though they resulted only in opening up commercial The
North-West Passage relations with Arkhangel, initiated the search for a north-east passage. Again and again the merchants of London, and of Holland also, equipped expeditions to seek for these passages. The greater part of our knowledge of Arctic lands is thus due to Europe's thrust for the Eastern trade. The majority of these voyages were to the west but Hudson went north between Greenland and Spitzbergen in a vain attempt to reach Japan across the Pole. The expedition of Sir John Franklin in 1845, which met with disaster, and the numerous search expeditions in succeeding years proved beyond all doubt that the north-west passage, although it existed, was not a practical commercial route, and it was not until 1905 that 
the Norwegian, Roald Amundsen, actually accomplished it, taking a small vessel round the north of North America.

The north-east passage was first traversed in 1878 when The Baron A. E. Nordenskjöld circumnavigated North-East Europe and Asia, but it, too, is of no commercial Passage value as a through route.

These northern sea routes were useless for trade and so they came to be replaced by overland railways. In a sense the Canadian Pacific and the Canadian Grand Trunk railways, and the TransSiberian railway are the practical fulfilments of the dreams of north-west and north-east passages.

\section{MODERN TRADE}

To trace the influence of European demand for Eastern products leads to the story of the exploration of the world. Enough has been said to show that the voyages in the grcat era Development of maritime discovery owed their inspiration to of Ocean Commerce this demand, and resulted in most of the sea coasts of the world becoming known. With this development of ocean commerce ships grew in size and seaworthiness and skill in navigation increased. The result was not only that a ship could carry a much larger cargo than of old but could carry it more safely and quickly. This had the effect of bringing a greater abundance of Eastern products into Europe and of lowering their prices, until eventually with the growing civilization of Europe luxuries came to be looked upon as necessities, and such commodities as tea and pepper were in universal demand. The coming of the steamer and its displacement of the sailing ship on most routes further accentuated this change.

In 1869 the opening of the Suez Canal caused the virtual abandonment of the Cape route and the return of the Eastern trade to the Mediterranean route. That sea regained some Revival of measure of its old importance and became again
Iediterranean Mediterranean a highway of trade. The new route to the East
Trade by the canal is considerably shorter than the old route by the Cape. From London to Calcutta via the Suez Canal is 3,700 miles shorter than via the Cape.

It was the necessity of securing our route to the East that led to British and French interference in Egypt in 1878 and subsequent 
British control. In 1915, when several lines to the East announced their temporary change from the Suez to the Cape route it was the Turko-German threats to the Suez Canal that caused this retrograde step. The Turkish menace, which in the fifteenth century had checked the Mediterranean trade and taught Europe to look to the Atlantic recurred after more than four hundred years, and led to similar results.

It is not merely by the curtailing of distance that the Suez route offers advantages. Traffic by the canal passes close to Mediterranean lands and can make many profitable calls which entail little deviation. The Cape routc offers none of importance except Cape Town.

The Baghdad railway which, under German auspices, was begun at Scutari and laid across Anatolia to the Euphrates valley, was to be a new overland route to the East. Its

The Baghdad Railway object was to link central and northern Europe with the East independently of the Mediterranean sea way. When Germany courted Turkey and drew that unfortunate country into the war, it was with the hope of obtaining control over a route to the East independent of our Mediterranean route and one that could at the same time threaten it. The Drang nach Osten, as Miss E. C. Semple has pointed out, was but a recurrence of Phoenicia's penetration of Mesopotamia and her establishment of trading colonies, of Alexander the Great's eastward march to the Euphrates, and of Rome's expansion into this strategic region. The geographical factors have remained the same through the ages though the actors have changed in race, nationality, and civilization.

When the Mediterranean once more became a great highway trade had taken on some new aspects. The use of coal for industrial purposes by this time had led to great manufacturing activity in certain lands, notably Great Britain.

The result of this was twofold : first, it gave rise to a demand for raw materials, second, it created a need for imported food for those growing manufacturing communities which Demand for produce none. Although, as a rule, manufactures
Food and Raw Materials at first depend on local raw material they eventually have to import. Many manufactures come to depend wholly on imported raw material. Extensive 
manufacturing leads to a demand for markets for the manufactured goods. A new type of trade arises.

The carriage of raw materials, food, and manufactured goods are the chief aspects of world commerce to-day. The trade in luxuries, while it still continues, is relatively less important than of old. The Phoenician ship-

"With a cargo of ivory,

And apes and peacocks,

Sandalwood, cedarwood, and sweet white wine,"

was a characteristic of that era of trade as the tramp steamer is of this.

" Dirty British coaster with a salt-caked smoke stack

Butting through the Channel in the mad March days,

With a cargo of Tyne coal,

Road-rails, pig-lead,

Fircwood, iron-ware, and cheap tin-trays."

A highly organized industrial country with a great diversity of manufactures, draws raw materials from near and far. Generally speaking it is the lands with abundant coal which

Overseas

Industrial

Development import raw materials, and it is the tropical lands and the new countries which export raw materials and import manufactured goods. Europe having led the world in manufacturing activity used to take the bulk of the available raw materials, but as the new lands become more densely populated by settlers from Europe and natural incrcase, industrial development began overseas. The tendency is for the new countries to decrease their export of raw material and their import of manufactured goods.

No civilized country with complex wants can become entirely self-supporting: certain materials are always wanting. The United States, owing to its size and range of climate, alone approximates to a state of self-support, but they lack certain tropical products and certain mincral ores. America is now using more of her raw materials and food and has less of both to export. Within her vast domain there are wide markets for her own manufactured goods but many are exported.

Australia at one time exported all her raw materials but now is utilizing many in home manufactures. A land like the Argentine 
Republic, deficient in coal, can never become a manufacturing country on a large scale unless other sources of power are utilized.

The manufacturing nations of the world are in temperate regions, chiefly in the northern hemisphere, and they will continue to demand from the tropics commodities which they

Exports and Imports cannot grow, rubber, cocoa, spices, various fibres, palm oil, copra, different kinds of timber and many fruits. In return they will send machinery, cloth and various manufactured goods. This trade will persist, for it is unlikely that tropical lands will ever become centres of manufacture. On the other hand the east and west trade between temperate lands will tend to change as raw materials are manufactured in their land of production, and each land becomes more and more self-supporting as far as temperate products are concerned. In the course of time no doubt the export of food from new colonies of settlement to older and more densely populated ones will cease, as the new lands increase their population and as a large proportion of the people, engaged in manufacture, cease to produce food. That will lead to a state of matters in which each land, by more intensive agriculture, must produce its own food or import from the luxuriant lands of the tropics which, under white supervision, will be made to yield a surplus. 


\section{CHAPTER XVI}

\section{THE ORIGIN AND GROWTH OF TOWNS}

VILLAGES and towns do not arise haphazard over the country side. Their origin and growth is a material expression of the activities and mode of life of the community. The segregation of man into definite centres of greater or less size is an outcome of the operation of geographical controls, past and present. No explanation of urban geography is complete without a study of the history of the region. That alone can explain certain manifestations of which the cause no longer operates. A town must be regarded as an evolving social organism. As Prof. Patrick Geddes has expressed it, a city is not only a place in space, it is also a drama in time.

Important as geographical factors are in the interpretation of the origin and growth of villages and towns, it must not be forgotten

Population of that the other factors also operate. To a certain Towns extent size begets size : a town of vigorous growth attracts population beyond the immediate requirements of industries. The gregarious habit of man, which he shares with many of the lower mammals, leads to crowding for crowding's sake. Town life has a kind of magnetic attraction especially for the less individualized types of mankind. This leads to a depopulation of the countryside and smaller centres of population in favour of the larger ones, quite apart from and in addition to the normal growing demand for labour in centres of increasing manufactures. When once a town attains the position of a national or even regional capital, circumstances favour its continued growth. Moreover, a capital attracts population not necessarily dependent on its activities. Incidentally, it may be noted the gregarious trait in mankind is a factor which adds to the other difficulties of city improvement and the gradual loosening of congestion in urban areas.

In analysing the geography of a town distinction must be made between the general situation in regard to the neighbouring countryside and the actual site. Thus a situation midway between the Pentland hills and the Firth of Forth was obviously favoured 
in the early days of Scottish history as commanding the route from England to the heart of Scotland. The actual site of Edinburgh was decided by the volcanic plug accessible only from

Situation of Towns one side and fringed with marshes on the north. Changed times have not decreased the value of the situation but assess the site rather from its picturesqueness than from its utility.

The wide estuary of the Thames leads into the best part of agricultural England and opens to the narrow seas across which lie the ports of the mainland. These reasons were sufficient in the early days of England to give capital value to the estuary but it was firm ground on the swampy fringes of the river that decided the actual site of London.

Again it must be noted that the factors which originally caused population to segregate in a spot are not necessarily the factors which promoted the growth of that village to a town or city. It was as a market village for the neighbouring dales that Sheffield originated, but its great growth is due entirely to the steel industry. Scarborough began its existence as a fishing haven but grew to its present size as a watering place.

Only the chief factors in urban geography can be noted, but a passing reference must be made to such vital influences as the occurrence of drinking-water at all seasons of the

Growth of Towns year, the proximity of fertile land, the confluence of routes, the river ford, the meeting of diverse rural activities, and defensive positions. Before the road and railway era water transit was a factor of much importance. These and other factors bring the village into being. The growth of a town is dependent, as a rule, on its being either a focus of trade routes or an industrial centre.

A market town grows large and important if the tributary area is rich and prosperous, but as a rule no market town outgrows the locality, that is, the area easily reached in

Market Towns half a day by slow farm wagons, unless it turns to manufactures on a large scale. Some market towns, however, lie on important trunk routes or at the focus of several, in which case their tributary area is larger than otherwise. Leeds commanding the easy Aire Gap leading through the Pennines, Salisbury at the convergence of many routes, Carlisle in the heart 
of an isolated plain, or Winchester at a gap in the downs, are examples, although manufactures in most of these cases have also stimulated growth.

Where goods in large quantity break bulk trade towns grow quickest. This explains the trade centres where a navigable river makes its widest detour, like Timbuktu and its

Rivers and

Trade Centres port where the Saharan caravan trade transfers to river transport. Perm, on the Kama, where the road-borne trade of Siberia meets the river routes of Russia, is another example. Chicago marks the southern end of the great North American lakes: traffic between Boston, New York, and other eastern ports on the one side and the well-populated northwestcrn states on the other must pass that point. A good instance of a railway causing the growth of a trade centre is to be seen in the case of Novo-Nikolaevsk, which stands on the River Ob at the crossing of the Siberian railway. Here the trade of the rich lands of the Altai coming by the $\mathrm{Ob}$ is transferred to the railway. NovoNikolaevsk has grown in less than twenty years from a tiny village to a town of nearly 100,000 inhabitants.

Change between sea and land transport affords the best examples of the growth of trading towns. Few seaports probably originated as trade centres. They were rather fishing havens with local interests in the beginning. On the other hand scme towns of ancient standing, like Alexandria, Marseilles, and Cadiz were founded for trade purposes. Later examples are such ports as Immingham, La Plata, and the new West African port, Port Harcourt.

Many considerations, some of which change from age to age, make a useful seaport capable of growth. In general terms these factors may be separated into two groups, those Factors in which pertain to the sea and those which pertain Seaports to the land. A seaport must contain a harbour which is easy of access by water deep enough for large vessels and reasonably clcar of reefs and shoals. It must have good sheltered anchorage in shallow water with soft ground in which anchors can get a firm hold. These considerations were more important in the days of sail than in this age of steam. Provided these conditions are fulfilled the further inland a seaport arose the more likelihood it had of growth because of the larger area with 
which it was in direct communication. This consideration had more force before the railway period than nowadays. Hence one reason for the growth of towns at the head of navigation on rivers. Such sites were good distributing and collecting centres.

All natural harbours do not give rise to seaports. On many coasts there are fine harbours that are practically devoid of population. An essential factor in the origin and growth of a seaport is a productive and populated hinterland. Without this trade cannot arise. The area of the hinterland of a port depends on various factors. Physical circumstances may restrict land communications or limit the area of dense population; the rivalry of other ports may make itself felt. Railway connections may make the hinterland very extensive if not for all at least for some aspects of the trade of the port. Thus Aberdeen sends most of its fish to London, the demand of which made the trawling industry grow to its present dimensions and brought great prosperity to the town. Narvik, on a barren part of the Norwegian coast, has its only hinterland some $\mathbf{1 7 0}$ miles distant by railway in the Gellivara ironfields of Sweden.

Growth in the size of ocean-going vessels has led to a new type of seaport which supplements the older ports up rivers. These outports, nearer to or actually on the sea, grow

Modern Vessels Effect on Seaports rapidly by virtue of railways to the hinterland. Examples are Rouen with its outport of Havre, Bremen and Bremerhaven, or London and Til-

bury. In most cases the older port has been so long established as a trade centre that its prosperity is not adversely affected but rather enhanced by the new port which becomes a kind of trade suburb. The old port remains the trade centre. Artificial measures frequently have to be taken by a river port to secure a channel for moderate-sized vessels. It is only by constant dredging of river silt that Glasgow remains accessible to large vessels.

The growth of a port is not always in direct relation to the size and productiveness of its hinterland. Entrepôt trade, that is to say goods in transit, may be landed and distributed again by sea or minor routes. Much of the trade of London is of this nature. 
Seaports may arise on coasts which afford few facilities for approach or harbourage provided the demands of the hinterland are sufficiently insistent. A trade centre may Artificial thus be created which leads to the necessity of
Harbour Harbour
Construction artificial harbour construction. Madras is a case in point, and Buenos Aires is largely another illustration. Dover is an example in which the demand is a traffic not in trade commodities but in passengers and mails.

Success leads to greater success and growth begets growth. The process once started bears itself forward. The urban organism may not be healthy, but health is not a necessary criterion of growth. Trade pours into a town: its hinterland widens : traffic in transit increases. A town which is busy with trade and receives much raw material starts manufactures. Even if fuel is absent other circumstances are favourable. No better example can be found than London with its numerous factories most of which bear no relation to geographical conditions except a populous market at hand, abundant labour and facilities for distribution. The glass, leather, and metal ware of mediaeval Venice were the result not of local material but of wide trade relations.

In contrast to trade centres which owe their size to nodality on

Industrial

Towns

The great industrial towns on coalfields owe their growth, but rarely their origin, to the use of coal in manufactures. Towns like Newcastle, Leeds, Sheffield, or Glasgow were

Growth of

Industrial Towns trade routes, there are great industrial towns many of, which are little more than gigantic workshops, with a very high proportion of artisan population. originally market centres or seaports which have proved valuable sites for manufacturing industry. Towns of this nature are freed from the geographical controls which limit the size of market towns and their proximity to one another. Manufacturing centres grow out of all proportion to regional considerations and two or more adjoining ones may even coalesce. Villages are absorbed as the urban organism spreads over the countryside and remain imbedded in the growing town as suburban foci. The rapid growth of manufacturing towns in many cases has led to crowding, unsightliness, and conditions far from healthy from both physical and moral standpoints. But there is no reason why a town whose future expansion 
is foreseen well ahead should not grow on well-planned lines carefully decided in relation to the site and environment. Here the regional survey of the geographer comes to the help of the town planner.

The rapid growth of smoky manufacturing centres led, in the nineteenth century, to the growth of another type of town. The health resort and pleasure town which is generally Health Resorts an overgrown fishing haven, is the direct outcome of the industrial era. Every developed coalfield that supports a dense manufacturing population stimulates the growth of seaside or upland pleasure resorts. Great capitals also have their dependent seaside resorts. A few of such towns are artificial creations, generally of railway companies which can offer sufficient inducements in the way of fast direct trains, to give their experimental resorts a good start.

The mining of gold, silver, and metallic ores not infrequently gives rise to towns of phenomenally rapid growth. Such towns are mainly distributing centres for the adjacent Mining Towns mining fields. Dawson City was founded in 1896, at the beginning of the great gold "boom" in Klondyke. In three years it was a city of 25,000 inhabitants, but by 1913 , with the partial exhaustion of the goldfields, had shrunk to 2,000. San Francisco was a tiny port for the cattle ranchers of the Californian valley when gold was discovered in the Sierra Nevada in 1848. In one year a village of 1,000 inhabitants grew to a town of over 15,000 . The discovery of the Comstock silver lode in Nevada made Virginia City, and the exhaustion of the silver caused its rapid decline.

Lastly there must be noted a small category of towns whose site has been arbitrarily chosen, or at least where growth is not due to geographical factors. Canberra, the Federal capital of the Australian Commonwealth, is being built on an entirely new site in a valley of the Australian Alps. Washington was chosen in $\mathbf{1 7 9 0}$ as the capital of the United States and has grown in consequence. Petrograd founded in 1703 by Peter the Great, had little in its situation or site to favour its importance and yet it grew because for two centuries it was the nominal capital of the Russian Empire. 


\section{CHAPTER XVII}

TRADE ROUTES BY SEA

\section{SAIL AND STEAM}

Ir has already been shown that from the early days of long distance commerce the way east and west between the Indian Ocean and the Mediterranean surpassed all others in importance. The Portuguese and Spanish discoveries laid the foundation of ocean trading and the complex web of routes that now cover the oceans of the world. The steamship, with its precision in navigation, established fairly definite ocean highroads in place of the ill-defined ways followed by the sailing ships.

The world's seaborne commerce to-day is carried on by both sailing ships and steamers. Although the number of deep-water

Sailing Ship sailing ships is decreasing they persist on certain Routes

is to leave a European port for Australia with a general cargo of manufactured goods. Waiting for a fair wind the ship goes down the English Channel and tries to make long. $10^{\circ}$ or $12^{\circ} \mathrm{W}$. before standing to the south into the north-east trades. She crosses the equatorial calms usually well to the west and sails more or less south by east through the south-east trades into the roaring forties making a long detour that often brings her within sight of Tristan da Cunha, and reaching the meridian of Greenwich in about lat. $36^{\circ} \mathrm{S}$. Thence "running down the easting" to Australian or New Zealand ports is comparatively easy. A homeward course is frequently from Newcastle, N.S.W., with coal for the South American coast, perhaps Valparaiso, which is reached by the help of the westerly winds after a southerly course. Further north at Iquique, Antofagasta or other Chilean port a cargo of nitrate may be loaded and the vessels return home round Cape Horn again taking advantage of prevailing winds. In the Atlantic she turns north-east of the Falklands depending on the westerlies till she picks up the south-east trades. The doldrums are crossed in about long. $28^{\circ} \mathrm{W}$., sometimes very slowly, and then the northeast trades necessitate a wide sweep into the western ocean and Sargasso Sea till the westerlies are caught about the Azores and take the vessel to the English Channel. 
Other sailing ships load wheat in Australia and return direct to Europe via Cape Horn, while others go from Australian ports to San Francisco or Portland (Oregon) to load wheat for the homeward voyage. A vessel provided only with sail power bound from Australia to California has to follow a somewhat devious route. which shows seasonal variations but seldom permits a quick passage.

In the days of sail and auxiliary steam the P. \& O. liners went to Australia by the "Cape" and returned by the "Horn" to take advantage of the winds. Certain steamers between Britain and New Zealand, until a recent date, took a similar course.

Sailing ships are not confined to these routes but in no seas do they find more favourable conditions of wind. Sometimes they try to round Cape Horn from east to west, against

Wind

Conditions the prevailing wind. That is a difficult task and may baffle a ship for weeks on end. She has either to hug the land and watch a chance to slip round in a lull of wind or stand south to pick up the polar easterlies and run the risk of encountering ice.

A voyage from Australia, New Zealand, or California to Europe takes a sailing ship about three months during which she probably sights no land. There is greater safety in the open sea. A cargo of grain, nitrate, or perhaps ore is not as a rule shipped to a definite port. Its ultimate destination is generally unknown when the vessel puts to sea, for the cargo is sold while underway. Sailing ships bound for Europe generally sail for the United Kingdom or the Continent bound for Falmouth or Queenstown for orders. The wind blowing at the time the vessel reaches the English Channel determines which port is made. Her orders send the ship to the port in which the cargo has found a buyer.

The Suez Canal route to the East is always avoided by sailing ships. It would entail towage through the canal which, in addition to canal dues, would stultify the chief value

Routes

Avoided by

Sailing Ships of the sailing ship, namely, its cheapness. And the towage would have to be continued in the Red Sea, in most months of the year. Similarly the Panama Canal route will never be used by sailing ships. The landlocked Caribbean Sea is none too happy a place for a ship without steam power, and the Gulf of Panama is dreaded by sailors on account of its prevalent calms, which indèed are as 
hostile to sailing vessels as head winds: the latter may be overcome by tacking if there be sea room, but the former admit of no release except by slow drifting.

Ocean traffic by steamers is either in regular liners or " tramps." Liners have definitely appointed routes and ports of call and usually sail on fixed dates. Cargo destined for

Liners' Ports of Call liners must be brought to their ports of call by land transit or coasting vessels, and there transhipped. Many liners carry passengers and mails as well as cargo and others carry cargo alone. On a few of the most frequented routes passengers are specially catered for, but on most routes they are a consideration secondary to cargo from a paying standpoint.

Tramp steamers, on the other hand, have no regular routes. As their name implies they tramp the oceans picking up cargo whenever they can and are available in any port

Routes of Tramp Steamers of all the oceans where need and profit calls them. Generally they endeavour to have a cargo every time they put to sea, but if a profitable freight offers at a distant port a tramp goes thither in ballast to avoid lying idle until an outward freight turns up. Sometimes a tramp is on a time charter, that is for so many months or years she is hired to run between specified ports with certain cargoes, say between Buenos Aires and England, taking grain homeward and coal outward. Sailing ships often follow the tramp principle but their sphere of usefulness is restricted, for reasons already discussed. A tramp having to make what she can, takes low freights rather than none at all. The competition among this class of steamer is particularly keen because the cost of embarking on such an enterprise as the ownership of a tramp steamer is comparatively small and the ocean highway being free to all there is a fair chance of a quick return for capital invested.

Freights vary with the amount of tonnage required and available. During the war the tramp owner had a rich harvest. The Government requisitioned much tonnage and enemy

"Tramp" action took a heavy toll, with the result that the number of ships left for commercial purposes was quite inadequate, and so freights rose to a figure they had never before reached.

The successful management of a line of tramp steamers requires 
a considerable knowledge of commercial geography in order that the vessels may be available where they are most required. The time of the harvest of food and industrial crops in all parts of the world, their success or failure depending on climatic causes, labour conditions affecting harvest and influencing demand, dislocations of markets caused by wars and social upheavals-all these and other considerations must be borne in mind. The reporting of the movements of all vessels by Lloyd's signal stations materially helps. A tramp owner must always look well ahead or he may find his ships unemployed or at a port far distant from where the paying freight offers. This question of freights, more than distance from coalfields, determines the price of coal at the world's coaling stations on ocean routes.

A return freight for the collier cheapens the coal which it brings. If the vessel has to return the whole or part of the way in ballast,

Homeward Cargoes

the outward-borne coal must pay for both journeys and so be sold at a high price. Coal at Gibraltar is little cheaper than at Port Said although Gibraltar is not half way from Cardiff to Port Said. At Gibraltar no homeward freight is likely but if no freight offers at Port Said the Black Sea ports with their grain traffic, or other Egyptian ports with their cotton, are near at hand and will furnish a cargo. Even Colombo can sell Welsh coal, despite the Suez Canal dues, at a reasonable price because India and Burmese ports are sure to provide homeward cargoes, it may be rice from Rangoon, jute from Chittagong, or other commodities. At Aden, on the other hand, coal is dear because Aden lies on the edge of a barren land which produces little for export except coffee, or by transhipment from Africa a certain amount of ivory and ostrich feathers. Coal at Buenos Aires would be more expensive if the vessels that brought it were not in eager demand to take back wheat and maize, wool and hides. On the other hand at the Falkland Islands coal is ridiculously dear for the demand is small and return freights are unobtainable. ${ }^{1}$

\section{ATLANTIC ROUTES}

The greatest volume of ocean traffic follows the North Atlantic route from British and continental ports to the United States.

1 These considerations are applicable to normal times. The effect of the dislocation caused by the war is still being felt in shipments of coal. 
It is not generally realized that the traffic goes south of west to reach the American ports, for the English Channel and the Gulf of St. Lawrence or southern Labrador are in the same latitude. Furthermore, great circle routes, which are a great advantage in these high latitudes, take ships well to the north.

More northerly and so shorter tracks are followed from August to January, than during the rest of the year when the prevalence of polar ice on the Newfoundland banks necessitates North
Atlantic Route

a safer course. The loss of the Titanic in April, 1912, by collision with an iceberg recalls the dangers of ice. The autumn route from Liverpool to New York is 3,079 miles, and the winter and spring route is 3,207 miles. From June to November shipping bound to and from the St. Lawrence takes a still more northerly route and passes north of Newfoundland. From November to April the St. Lawrence ports are closed by ice and Canadian traffic has its own terminus in Halifax, Nova Scotia, or United States ports. Great circles, which can only be well understood on a globe, cause vessels from the southern Atlantic ports of the United States and the Gulf ports to steam more or less parallel to the coast of North America before turning eastward to join the great stream of North Atlantic traffic. This enables such vessels to call at Norfolk, Virginia, for coal without deviating to any considerable degree from their course. There are no mid-Atlantic islands to serve as coaling stations on these tracks.

The greater part of the North Atlantic traffic has its American terminus in New York but a fair proportion uses Philadelphia, Baltimore, Boston, and the Canadian ports.

Apart from the enormous quantity of freight carried on this route it has the greatest passenger traffic of all ocean routes. The largest and most luxurious as well as the fastest

Passenger Traffic liners run between North America and Europe. This is also the principal route for emigrants. The passenger traffic sets west, and it is only at the height of the American tourist season that there is a considerable eastward stream, but this, of course, does not affect the emigrant steamers. On the other hand, the cargo traffic, largely in raw materials, as cotton, tobacco, timber, and certain ores as well as corn, meat, and other foods, sets eastward. A great many westward bound 
cargo vessels must make the journey in ballast as European manufactured goods are not imported to America in sufficient bulk to fill them.

With the opening of the new Hudson Bay railway, Port Nelson, on Hudson Bay, will become an Atlantic seaport for at least four months in the summer and early autumn. Wheat from the western plains of Canada, say Saskatoon, now reaches Liverpool by rail to Port Arthur, 1,489 miles, lake steamers to Montreal, 471 miles, and sea to Liverpool, 2,888 miles. The Hudson Bay route will entail only 697 miles of rail transit and 2,966 miles of ocean transit. If this route proves useful it will cause the most northern stream of traffic in the Atlantic.

Several other noteworthy trade routes cross the North Atlantic. That from American ports to the Mediterranean will be considered with the Eastern routes. The route from Europe other to the West Indies and Central America runs Important
Atlantic Routes south-west across the North Atlantic. The traffic on this route is now augmented by shipping bound to and from the Pacific via the Panama Canal (p. 173). Lastly, there are the routes to South America from both American and European ports. These join near the equator. The terminus for much of the shipping on these routes is Buenos Aires, but a great deal goes to other ports on the Atlantic coast while many steamers pass through the Straits of Magellan to the southern Pacific ports of South America. Before the opening of the Panama Canal all the trade of Pacific South America with Europe, and most of that with North America, had to pass via the Straits of Magellan. The trade to South America from northern temperate regions is mainly in manufactured goods and in coal, for the continent is poorly endowed with that mineral. The return freights are raw materials and food. There is also a good deal of outward passenger traffic on this route but the emigrant traffic is almost exclusively from the Mediterranean.

Between tropical Africa and Europe there is much commerce, and since the Sahara cuts off from Europe the greater part of Africa nearly all this commerce is seaborne. The

The Airiean Sea Route their cargo. The most important, and one of the oldest routes, 
is not to tropical Africa but to temperate South Africa ; that is the route from Britain to Cape Town. This has the choice of Madeira or the Canaries for coaling stations. This route is also followed by the steamers which reach Australia via the Cape. Ascension and St. Helena are off the direct route to the Cape and only intermediate vessels and not the fastest mail boats touch there. On ocean routes to Africa there is comparatively little passenger traffic, even in emigrants, to South Africa.

African trade resembles South American as far as the homeward trade in raw materials and outward trade in manufactured goods are concerned, but there is little in it to compare with the trade in food to Europe that occurs from the Argentine.

Of the outward freights to South Africa, excluding those which go on to Australia, only a little more than half returns direct. The rest makes chiefly for Indian ports in ballast or with Natal coal to pick up profitable freights for the return journey via the Suez Canal.

Between Buenos Aires and Cape Town there is little traffic and no regular trade because the two continents are mutually independent in their products and wants.

\section{EASTERN ROUTES}

Second only to the North Atlantic route in volume of traffic is that via the Mediterranean and the Suez Canal to and from India, East Africa, Australia, and the Far East.

The strength of the outward trade stream is from British and other North Sea and Channel ports. At Gibraltar-the first coaling station-it is augmented by some American Mail and traffic. From there the direct route is via Malta to Port Said, the northern entrance of the Suez Canal, and, mean and discreditable town as it is, the gateway between the Western and Eastern worlds. The mail steamers to the East and Australia make deviations from the direct course in order to pick up passengers and mails. The P. \& O. steamers call for this purpose at Marseilles, but in the outward journey they used to receive their mails at Port Said whither they were carried by express boats from Brindisi. The overland route to Brindisi allowed mails and a limited number of passengers to leave London two days after the mail boat had sailed, and overtake it at Port Said. On the homeward journey the same plan was adopted. 
Marseilles is reached by the steamer one week after leaving London but is within twenty-four of London by rail. The Orient boats for Australia call at Toulon and Naples for passengers and mails. Formerly they shipped their mails at Taranto in southern Italy. This last call was not made on the homeward journey when the mails were transhipped at Port Said for Brindisi to the P. \& O. mail express.

From Port Said, where coal is shipped, the eastern traffic traverses the canal and goes down the Red Sea. Aden is another coaling station. Here the route divides; the main Coaling stream going to Colombo but important branches Stations en route making for either Bombay or the many East African ports. At Colombo, which is an important coaling station, the route again divides. The main stream of traffic goes east to the Straits of Malacca, via Penang and Singapore to the Pacific, but the Australian traffic turns south-eastward and enters the long stretch of 3,120 miles to Fremantle. Routes also diverge to Madras, Calcutta, and Rangoon.

The Mediterranean-Asiatic route passes through the heart of the world, touches more lands and serves more people than any other route. It has been calculated that with its many Mediterranean ports of call it reaches one way or another about Asiatic Route three quarters of the total population of the globe. Along this highway the East sends its raw materials and food to Europe receiving in return the manufactured articles of the Western world. The Suez Canal, aptly termed the Ditch, is the chief nodal point of the route and because of its liability to attack from land the weak link in the chain of world wide trade.

The wheat, wool, gold, and copper of Australia, the wool and much of the mutton of New Zealand, the teas of India, Ceylon, and China, the sugar of Java, the rice of Indo-China

\section{Eastern}

Goods Traflie and Burma, the jute of Bengal, the wheat of the

Punjab, the cotton of the Deccan, the sugar and tobacco of the Philippines, the spices of Ceylon and Malaya, the dates of the Persian Gulf, the coffee of Arabia, the soya beans of Manchuria, the tin of the Straits Settlements, the petroleum of the Persian Gulf and Burma, the cloves of Zanzibar, the pearls and pearl shell of Burma and Australia, the copra of the Pacific Islands, 
the rubber, ivory, and hides of East Africa-all pass through the Suez Canal to Europe. In return there go eastward machinery of all sorts, iron and steel work, Welsh coal, manufactured cotton goods and clothing and an endless variety of the industrial products of Europe's manufacturing activity. Some of these Eastern goods go direct to America across the Atlantic but America's share is small in comparison with the whole and much of it is transhipped in London. Along the Mediterranean also passes the commerce of the Black Sea and the Levant, including grain and petroleum from Black Sea ports, and wines and fruits from Mediterrancan ports. And all along the route there is, of course, intermediate traffic. Japan at the further end, year by year increases her import of food and raw materials, cotton, sugar, and rice from India, Java, and Indo-China, while conversely her coal and manufactured products go further west. Japanese coal goes as far as Singapore, and it is some years now since Japanese matches almost ousted Swedish ones in India. Japanese household articles are now pouring into Britain. In time to come Chinese manufactured goods will also find Western markets.

Another important steamer track across the Indian Ocean is that between South Africa and Australian or New Zealand ports. By this route the greater part of the emigrant

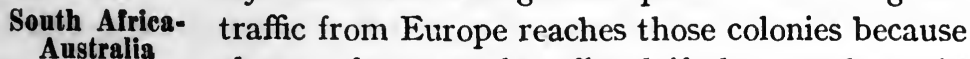
Route cheaper fares can be offered if the vessels avoid the high dues of the Suez Canal. For the same reason a great deal of the trade, except passengers and mails, from Europe to Australia passes that way although it is about 1,000 miles longer than via Suez. The vessels call at Cape Town for coal. Of the homeward traffic from Australia perhaps half goes by the Cape and half via Suez. Wool, an important homeward cargo, is valuable enough to go by the shorter route. Most of the vessels which return by the Cape coal at Durban and not Cape Town. This is owing to a northerly course being followed in order to escape the full force of the westerly winds.

On the route between South Africa and Australia vessels avoid the great circle track which, dipping to lat. $62^{\circ} \mathrm{S}$., is too near to Antarctic icebergs and pack-ice to be safe, espccially in winter. A more northerly course which remains north of lat. $44^{\circ} \mathrm{S}$. is followed although it adds several hundred miles to the journey. 


\section{PACIFIC ROUTES}

Commerce in the Pacific Ocean developed later than in other oceans. Most of the frequented routes followed the coasts until the opening of the Panama Canal brought several

Pacific Routes trans-oceanic tracks into prominence. There is a certain comparison between Atlantic and Pacific Oceans in direction of routes but not in volume or nature of traffic. The important North Pacific route is between Vancouver or San Francisco and Yokohama, Shanghai or Hong Kong. The great circle route between North America and Japanese or Chinese ports takes vessels as far north as the Aleutian Islands and so has to be lengthened by the flattening of the arc. The nearest approach to a great circle route which the distribution of land allows a vessel to follow from Panama to Japan goes within about 100 miles of San Francisco and so virtually coincides with other North Pacific routes. For steamers on this route San Francisco should afford a convenient coaling station 3,200 miles from Panama and 4,300 miles from Yokohama.

A globe shows clearly the advantageous commercial position of Yokohama since great circle traffic between ports from Singapore and Manila to Shanghai on the west and Prince

Pacific Commerce Rupert to Panama on the east must pass near it and will probably coal there after the long coalless stretch across the ocean. San Francisco, in want of local sources of coal, has to import supplies from British Columbia, Japan, and Australia. The chief volume of commerce across the North Pacific sets towards Asia with manufactured goods and food to Japan and China, for Japan has now to import food. Return freights are less easily obtained though valuable enough, even if not bulky, when they take the form of silk and Oriental art work. But an exception is the case of sugar from the Hawaiian Islands, which goes east to American ports or via the Panama Canal direct to New York. In some respects this North Pacific route is an alternative to the Suez Canal route to China and Japan but scarcely a rival, even as regards passenger traffic ; while the long overland journey in Canada effectively prohibits it being used as a route for goods from Europe to the East. Of course for passengers and mails to China, Japan, and even Australia via the Atlantic, the way by North America and the Pacific is the quickest if only because a large section 
of it is by rail and not by steamer. Regular steamer traffic across the tropical Pacific used to be confined to a few lines of steamship between San Francisco, Vancouver, and Australian ports via the Hawaiian, Samoan, Fiji or Society Islands, but now most of the fast traffic between Europe and New Zealand takes that route. Between South America and Australia there is little traffic since there is little to exchange. Most of what occurs is eastwardbound coal from New South Wales, as often as not in sailing ships. The South Pacific is an immense stretch of deserted ocean till to the south in the forties and fifties of latitude is the eastbound traffic via Cape Horn for Europe, Australian wheat and wool, New Zealand mutton and hides, and New Caledonian nickel-ore. The Australian coal for Chilean ports takes this route also when in sail, and for North American ports for part of the way across the ocean. The great circle route between Wellington and Cape Horn dips to lat. $67^{\circ} \mathrm{S}$. Vessels follow a course some 450 miles longer which keeps north of lat. $53^{\circ} \mathrm{S}$. till it has to bend south to round the Horn itself.

\section{PANAMA ROUTES}

The Panama Canal has already given rise to several new routes and to certain alterations in old routes. To understand these it is necessary in the first place to realize that practi-

Panama Canal cally the whole of South America lies to the east of Trade Routes North America, and secondly that the only sea route previous to the opening of the canal between eastern and western America was by Cape Horn or the Straits of Magellan. This is equivalent to saying that the Pacific Oceanthe last ocean to come into the world of commerce, excepting, of course, the Arctic Ocean-had only one entrance from the east. There is no commercial route round the north of America or the north of Asia. The Panama Canal, midway from north to south, cuts through this immense land barrier that lies athwart the world almost from pole to pole. Its influence, therefore, on trade routes is great in readjusting regular lines, in adding new ones and above all in facilitating the passage of tramp steamers to and from Pacific ports.

The manufacturing countries of the world, with the exception of Japan, lie on the Atlantic and its seas. The United States of America and even Canada are no exceptions to this statement 
because their industrial centres lie in the east separated by long overland journeys of over 3,000 miles from the Pacific. The first result of the Panama Canal has bcen to put the Pacific into closer relations with the manufacturing countries, an adjustment which operates more in favour of the United States than of Europe.

By Magellan Straits the distance between New York and San Francisco is 13,135 miles : by Panama it is only 5,262, a saving of 7,873 miles, or, in other words, a month's steaming Distances via Panama

for an 11 knot tramp. From Liverpool to San Francisco the canal effects a saving of 5,666 miles, or about twenty-one days for the same vessel. There is, of course, the same saving between New York or Liverpool and Vancouver or other Pacific ports of North America. Again the many Pacific ports of South America, so isolated in the past, are brought into close relationship with Atlantic ports. Thus Guayaquil in Ecuador, the most northern of these ports is 10,215 miles from New York via Magellan, but only 2,810 miles via Panama. From Liverpool it is 10,582 miles, so the saving is less $(5,200$ miles), but even that is important. To Callao the canal shortens the route from New York by 6,250 miles, from Liverpool by 4,443 miles; while to Valparaiso, the chief port of Chile and one of the most southerly Pacific ports of importance the figures are 3,747 and 1,540 respectively in miles saved from New York and Liverpool. The distance from Liverpool to Valparaiso via Magellan (8,747 miles) is only 367 miles longer than from New York; and actually 49 miles shorter than from New Orleans. To othcr Pacific ports of the Americas there is a like difference.

So it is obvious that while by the Magellan route Europe is about equally placed with United States as far as distance is concerned in trading with these ports, the canal will materially change that and give the decided advantage to the United States. Needless to say the same applies to the Hawaiian Islands.

Now as regards Asiatic ports of the Pacific. Formerly all their trade to and from Europe and Atlantic ports of America passed either via Suez or via the Cape of Good Hope.

Asiatic Ports From New York to Yokohama by Suez is 13,564 miles, by the Cape of Good Hope 15,155 miles, and by Panama 9,835 milcs. The Cape route may be ruled out in these considerations. From Liverpool to Yokohama by Suez is 
11,678 miles, by Panama 12,372 miles, and the distances from other European Atlantic ports show a comparable advantage in favour of the Suez route. The distance from New York to Hong Kong via $S u \in z$ is 11,655 miles against 11,744 by Panama : that is to say, the Suez route is shorter by nearly 100 miles, a negligible mileage however in so long a stretch: other circumstances might easily counterbalance it. Liverpool to Hong Kong by Suez is 9,785 miles, and by Panama 13,957 miles. The conclusion is that for Asiatic ports east of Hong Kong the Panama route is an advantage to the United States but for no Asiatic ports is it an advantage to vessels from Europe. Needless to say, the advantage of the Sucz route to Europcan traffic for Indian Ocean ports is even more pronounced, and the same is true for American traffic, though not to the same degree.

But it must not be overlooked that the above figures show that Japanese and northern Chinese ports are, by the Panama Canal, Advantages of Panama Route brought nearer to the eastern or manufacturing side of the United States than they are to Europe. The reverse was formerly the case. So here again America benefits from the new canal.

We have seen that fast traffic to Australia from Europe follows the Suez route, but from New York the distance is shorter by the Cape of Good Hope. From New York to Melbourne by the Cape is 13,083 miles, by Panama it is 10,392 miles. From Liverpool to Melbourne by Suez is 11,654 miles and by Panama 12,966 miles. Therefore to Melbourne the new route is advantageous only to American traffic and it puts Melbourne nearer to America than to British and North Sea ports by a few miles, but not enough to give a decided advantage. To Sydney, however, the advantage is more decided. Sydney used to be 1,423 miles nearer to Liverpool than to New York by the shortest route: it is now 2,383 miles nearer to New York than to Liverpool, and that is not a negligible distance for it means about nine days steaming for a tramp and about six days steaming for a 16 -knot liner.

Lastly, there is New Zealand. New York to Wellington, N.Z., via Magellan Straits, formerly the shortest route, is 11,414 miles, but via Panama is only 8,872 miles. Liverpool to Wellington, N.Z., via Cape Town is 13,157 miles, via Suez is 12,989 miles, and via Panama 11,058 miles. That is to say, the Panama Canal brings 
Britain nearer to New Zealand than it used to be, but gives a greater advantage to America.

It may be useful to summarize these conclusions as follows-

1. The canal most considerably reduces the distance between eastern and western ports of Canada and the United States.

2. It brings the Pacific seaboard of South America into near contact with the manufacturing part of the United States, and to a less extent with Europe.

3. It brings Chinese and Japanese ports (from Hong Kong northwards) nearer to the Atlantic ports of North America than they are at present, but not nearer than European ports.

4. It brings Australian ports nearer to the Atlantic ports of North America but not to European ports and gives them a slight advantage compared with European ports.

5. It brings New Zealand slightly nearer to Britain than it used to be, but gives a decided advantage to North America.

6. It does not shorten the road to Indian Ocean or Pacific ports as far east as Cochin China from either America or Europe.

Thus it will be seen that the Panama Canal is of far greater value to the United States than to Britain and, moreover, that to a great extent it reduces the disadvantages which the United States, compared with this country, has in distance to trading countries. To connect its widely-separated coasts was the principal aim of the Americans in undertaking this colossal work. In the SpanishAmerican war of 1898 the United States battleship Oregon had to travel from San Francisco via Cape Horn to the West Indies, where her services were required. Not only did the long road cause much delay but it exposed the Oregon to the dangers of attack and wreck. It was a perilous journey for a solitary battleship to take at top speed in time of war. The strategic consideration of the possible necessity of transferring her fleet rapidly from Atlantic to Pacific is one that the United States would be foolish to overlook. The Panama Canal makes the United States a Pacific as well as an Atlantic power.

The extent to which the Panama Canal will draw traffic away from the Suez Canal cannot be altogether foreseen until trade becomes normal, but certainly it will not be great. The bulk of the tonnage that passes through the Suez Canal bound East is from European ports to East African, India, Burmese Malayan, 
Australian, Chinese, and Japanese ports. It has been shown that the Panama Canal will shorten none of those routes. And while the new canal shortens certain routes from

Panama

$v$.

Suez Canal America which might therefore be expected to abandon the old Suez route, another consideration must not be overlooked. The route from Panama across the Pacific to Australia has no ports of call except Tahiti that would be profitable. From Panama to Japan and China it has been shown above (p. 172) that a call could easily be made at San Francisco, but there is no other. The Sandwich Islands are not on a direct route though it might be profitable to make a diversion to call there. The Panama route to Asia and Australia takes vessels across great void tracks of waste ocean. On the other hand the Suez route is studded with great ports serving rich and populous hinterlands. This may quite probably make it the preferable route of the two even in a case where it is longer in mileage. The question of canal dues must also be remembered since they make it costly to use a ship canal. The dues for the Panama Canal are 4s. 10d. per ton, that is for 100 cubic $\mathrm{ft}$. of carrying capacity. For vessels in ballast the dues are 40 per cent. less. In the case of the Suez Canal dues for loaded vessels are $8 \mathrm{fr}$. 50 centimes per ton. Vessels in ballast pay 6 francs a ton. There is also a toll of 10 francs per passenger over 12 years of age and 5 francs for every child. There are no passenger tolls in the Panama Canal.

While the Panama Canal will principally benefit the United States, Canada will reap many advantages. Her eastern and western ports

Effect on Export of Commodities

are now connected by a comparatively short sea route, but a more important result is that grain, lumber, tinned salmon and other commodities of export from the West will be able to reach Europe without the long journey round Cape Horn. The enormous deposits of coal in British Columbia will find a ready market at Panama and perhaps at San Francisco, coaling ports on the new routes; and her coal and iron resources in general as well as her water power will be developed as British Columbia emerges from her present isolation.

As coaling stations and repairing yards, more than one of our West Indian ports may be on the eve of more fruitful days, if the opportunities are seized before other nations in the West Indies forestall the British. The United States, with a quick eye to profit,

12-(1909) 
bought the Danish Virgin Islands in 1917, and will be able to build an important coaling station at the fine harbour of St. Thomas.

During the first six months of the Panama Canal as a waterway 95 per cent. of the vessels traversing it were on one of four routes, first, between Atlantic and Pacific coasts of the

Annual

Panama

Tonnage

United States; second, between the Pacific ports of North America and Europe; third, between the Pacific Coast of South America and Atlantic ports of North America and Europe; and fourthly, between Atlantic ports of the United States and the Far East.

It is interesting to note that the cargoes from the Pacific coast of South America were chiefly composed of nitrates and that the return freights were much less in bulk.

Now that shipping. has returned to its normal routes the use to which the Panama Canal is put can be more clearly seen. As regards liner routes from the British Isles, the New Zealand mail boats now go via Panama in place of Cape Horn, and fast traffic to Pacific ports of South America also uses the canal. These diversions of route have not affected the volume of traffic via the Suez Canal. 


\section{CHAPTER XVIII}

\section{LAND ROUTES}

\section{EUROPE}

THE dense population, high degree of development, and the relatively short distances have resulted in a network of routes in nearly all directions in Europe, the chief exceptions being the less developed mountainous lands of the Balkan Peninsula and the unproductive thinly populated Arctic borderlands. The configuration of Europe prevents the development of large rivers with long navigable courses except in Russia. Yet navigable rivers, even if short, are of much importance, especially in giving access to inland seaports.

The principal waterway of western Europe is the Rhine and its tributary, the Main. Light draught sea-going vessels reach Cologne, but the traffic is mainly by tugs and

The Rhine barges. The river is in use as far as Basel, some 500 miles from the mouth. Barge canals link Strassburg with the Marne, and Strassburg by the Burgundy Gate with the Doubs and Rhone.

The Rhone is not navigable from the sea owing to a delta, but suggestions have been made to circumvent the delta by a ship canal from Marseilles. Recently a remarkable

The Rhone canal was opened between Marseilles and the Rhone at Arles, a distance of 50 miles, of which $4 \frac{1}{2}$ miles are through a rock tunnel in the hills behind Marseilles. This canal has $10 \mathrm{ft}$. of water throughout.

In Germany the Elbe and the Oder are both navigable for long distances and can be entered from the sea. The Elbe is navigated at least to Prague in Cecho-Slovakia and the Oder to Breslau. There is canal connection between the two rivers. By the Treaty of Versailles these and other rivers are made open to the vessels of all nations (p. 124). 
The Danube, another international river, is the finest waterway in Europe. Sea-going vessels use the ports within 100 miles of the mouth and can ascend as high as the Iron The Danube Gates where the Danube breaks through the Transylvanian Alps. From there to Ulm, in south-western Germany, steamers navigate the river. The main tributaries of the Danube, the Tisza, Drave and Save are all important waterways. Danube navigation is linked by barge canals with that of the Rhine and the Oder.

The great plain of Russia has many navigable rivers but all are frozen for several months in winter. Their tortuous courses and shifting sandbanks do not facilitate their use, but

Russia's Navigable Rivers on account of the great distances and the comparatively poor development of railways, they are of importance. It was the rivers and easy passages from one to another that helped to knit the Russian plains into one political unit. After the storm of to-day has blown over the ease of communication on the Russian plain will probably lead again to a similar unity. In this connection it is of interest to remember that Russia, lying as it does between Europe and Asia, was in its early days a commercial rather than an industrial nation. The best waterway is the Volga but its great drawback is that it opens to the isolated Caspian and not the open sea. The Don and the Dnieper, the two main streams to the Black Sea, flow through productive lands but are fit only for shallow-draught vessels. Canals connect the chief Russian waterways, and in places are built beside unnavigable stretches with the result that water-borne traffic can pass from one end of the country to the other. 1 During the early years of the war several submarines were transported by river and canal from the White Sea to the Baltic.

The Arctic rivers have a future before them as routes for timber exports. The Pechora and its tributarics comprise several thousand miles of waterways fit for floating timber and in parts for steamers.

The distribution of relief in most parts of Europe offers few hindrances to the construction of railways. The chief physical obstacles are the inland seas which necessitate break in transit. Train ferries partly overcome this difficulty in the Baltic between Sweden and Denmark and Sweden and Germany. 
The existence of the broad mountain barrier in southern Europe extending from the Pyrenees to the Caucasus has given great importance to certain lowland routes and passes, notably the Rhone and Rhine valleys, the valleys leading to the Alpine passes, the Austrian and Carpathian gates, and the great Balkan valleys of the Morava, Maritza and Vardar.

Paris, Berlin and Moscow are the chief focal points of European railways. The course of only a few trunk lines can be noted here. From Paris a trunk route goes direct to the western

European Railway Centres end of the Pyrenees, then over the Iberian plateau avoiding the heights of the Sierra Guadarrama to Madrid (902 miles). From Madrid it continues south to the Guadalquivir valley and Cadiz, the port for Tangiers and Morocco. At Medina, 124 miles before Madrid, the main route to Lisbon, branches south-west : another line to Lisbon descends the Tagus valley from Madrid. South American mails used to be loaded at Lisbon where the steamer called four days out of Liverpool.

From Paris up the Yonne valley past Dijon and down the Rhone valley to Marseilles (535 miles) is the chief way from north-west Europe to the Mediterranean. It is the present route of all overland mail and passenger traffic between Britain and the Far East. This route saves six days on the voyage to or from London. The ParisMarseilles route continues eastward past Toulon along the Riviera and joins the Italian railways leading to Genoa, Rome and Naples. Express traffic to Italy from Paris takes a more direct route which leaves the Dijon-Marseilles line at Maçon and passes by Chambery, the Mont Cenis tunnel, Turin, Genoa and Pisa to Rome (900 miles) and Naples (1,060 miles). A route to Taranto and Brindisi, which used to be mail ports for the Far East, leaves this line at Turin and passes along the east of the Apennines. Another route from Paris leads from Dijon by the Lake of Geneva and the Simplon tunnel to Milan (552 miles), Venice ( 717 miles), and Trieste $(870$ miles). The shortest route from Calais, and therefore London, to Italy is across Flanders by Amiens and Châlons and through the Vosges mountains to Basel, by Lake Lucerne and the St. Gotthard tunnel to Milan (755 miles).

The Orient express from Paris to Constantinople ascends the Marne valley for some miles beyond Châlons. It then strikes eastward by Nancy and Strassburg, crosses the Rhine and descends 
its valley to Carlsruhe where it again turns eastward via Stuttgart, Ulm, and Munich to the Danube valley and Vienna (868 miles). From Vienna the train follows the Danube valley

The Orient Express to Budapest (163 miles), and Belgrade (388 miles). At Belgrade the line enters the Balkan valleys, first ascending the Morava valley to Nish (whence a branch runs south to Salonika over the watershed and down the Vardar valley), then crossing high ground via Sofia to the Maritza which it descends until it cuts across the plains to Constantinople, 1,960 miles from Paris. On this route at Vienna there joins the line from Berlin via the Elbe valley, Prague and the highlands of Moravia (446 miles).

An overland route to Constantinople via Milan is complete save for about 100 miles. From Milan it would pass north of the Adriatic and Trieste into the Save valley which it would descend to Belgrade there joining the present overland route to the East. It is claimed that by this route there would be a saving of some four hours, as compared with the Orient express via Vienna, between London and Belgrade.

An important southern route from Berlin is the route of the Nord-Sud express by Munich and the low Brenner Pass into the Trentino and the north Italian plain. By this route Venice is 800 miles from Berlin.

Across the plains of central Europe railways have to contend with few physical obstacles and go direct from centre to centre. To Berlin from the west important trunk routes Railways lead from Paris by the Oise and Meuse valleys
of Central Europe and Cologne (310 miles), joining there the route from Ostend and Brussels across the plain of Flanders. From Cologne to Berlin is 370 miles. Eastward from Berlin there are three trunk lines, the most northern to Danzig and Petrograd (984 miles), the middle one to Warsaw and Moscow (1,200 miles) and the southern one skirting the north of the Carpathians to Lemberg and Odessa (1,040 miles). Petrograd and Moscow both have direct lines to the Siberian railway (p. 186).

One branch line in Scandinavia must be noted. Copenhagen is connected by rail and train ferries with Esberg on the North Sea, Kiel for Hamburg on the Elbe, and Warnemünde for Berlin. From Malmö (15 miles across the Sound from Copenhagen) a line 
crosses the plains of southern Sweden to Stockholm (373 miles) and continues northward along the Baltic plains to Haparanda on the

Scandinavian Railways
Finnish frontier (809 miles from Stockholm).

About 135 miles north of Stockholm there joins the line from Bergen (631 miles) and Christiania, which includes the difficult route through the mountains of southern Norway where the line has to traverse 23 miles of tunnels and rise to a height of $4,268 \mathrm{ft}$. At Boden the Lapland railway from Narvik (272 miles) joins the northern branch line from Stockholm. Haparanda is being connected by bridge with the Finnish railways at Tornea whence a line goes south and east skirting the plateau of Finland, sending branches to the chief ports and reaching Petrograd after a course of 735 miles. The northern links of this route to Russia were completed in 1915 when the war gave it a value which has now been much lessened by the re-opening of Baltic navigation and the land routes through central Europe. The new line from Petrograd to Murmansk, through Russian Karelia, past several White Sea ports, has a length of 955 miles.

The various countries of Europe have many gauges which necessitates break of transit in through traffic. The standard gauge of Great Britain, $4 \mathrm{ft} .8 \frac{1}{2}$ ins., is also the normal European
Railway Gauges
gauge of Norway, Sweden, Germany, Austria, and
central Europe generally, and is much used in France. A metre gauge is used on local lines in France. Spain and Portugal have a $5 \mathrm{ft} .5 \frac{3}{4}$ in. gauge. Russia and Finland have a $5 \mathrm{ft}$. gauge. In Ireland a $5 \mathrm{ft} .3 \mathrm{in}$. gauge is common.

\section{ASIA}

From the earliest days of civilization there have been caravan routes linking China and India with the Near East through the desert and arid countries of central and south-western Asia. Such routes persist, especially in those regions where railways have not replaced the earlier means of transport.

Along other caravan routes railways have been built or are projected. Across Siberia nearly the whole route of the overland tea trade is now covered by rail. In central Asia lines have been built to tap the trade of great caravan centres like Semipalatinsk 
and Tashkent. A railway is rapidly supplanting the caravan on one of the oldest trade routes in the world, that between the Persian

Railways

Supersedo

Caravans Gulf, Mesopotamia, and the Levant. Damascus is now a railway junction and a line goes south to Medina in Arabia within measurable distance of the holy city of Mecca.

Navigable rivers play a considerable part in internal traffic in the peripheral lands of Asia. The interior, with its highlands and lack of rainfall, has few rivers of use to man except in the central plains of the west.

Asia Minor now has a trunk line practically complete from Scutari opposite Constantinople to Basra, a port on the Shat-cl-Arab within 60 miles of the Persian Gulf. This is the

Route of

Baghdad

Railway. Baghdad railway conceived and built largely by German enterprize. It has a gauge of $4 \mathrm{ft} .8 \frac{1}{2} \mathrm{in}$. The chief constructional difficulty was in piercing the four tunnels of the Taurus Range, near Adana. There is now through access from Smyrna or Scutari to Aleppo, some 840 miles, with branches to Levant ports of Messina and Alexandretta. From Aleppo, or rather a junction 8 miles north, the line continues eastward crossing the Euphrates at Jerablus and reaching the Tigris at Mosul which it follows to Baghdad, 1,500 miles from Constantinople. From Baghdad the line continues down the Tigris valley, a further 300 miles to Basia. It is claimed that by express train Basra will be within sixty-six hours of Constantinople and six days of London. A fast steamer from Basra could reach Bombay in three and a-half days. That is to say, Bombay will be nine and a-half days from London instead of thirteen, which was the pre-war record.

At Aleppo the Syrian railways join the Baghdad line. A trunk line runs the whole length of Syria breaking gauge at Rayak, the junction for the port of Beirut, to $3 \mathrm{ft}$. $5 \cdot 3$ in. from

The Syrian Railways

$4 \mathrm{ft} .8 \frac{1}{2}$ in. At Damascus, 24 miles from Aleppo, begins the Hedjaz railway which runs a distance of $\mathbf{8 2 0}$ miles through the desert to Medina.

The Syrian railways are now linked through Sinai to the Egyptian railways with a swing bridge over the Sucz Canal.

As regards inland navigation the Tigris is much more useful than the Euphrates. From Basra, which ocean-going vessels can reach, 
river steamers go to Mosul. The Euphrates is intermittently navigable as far up as Jerablus but vesscls seldom ascend beyond Hit.

India is well provided with railways. In the main they radiate from the western ports of Karachi, Bombay, and Goa, and the eastern ports of Madras and Calcutta. Several

Indian

Railways routes cross the country and trunk lines lead to the Punjab from Karachi, Bombay and Calcutta.

From the Karachi-Punjab line a branch runs into Baluchistan to Quetta and the borders of Afghanistan. Political complexities no less than engineering difficulties have so far prevented the extension of this line some 400 miles across Afghanistan to meet the Russian railways of central Asia. So far India has no trunk railway line with lands beyond its frontiers. Through rail connection with Ceylon is interrupted by only 20 miles of sea in Palk Strait. The chief gauges in India are $5 \mathrm{ft} .6 \mathrm{in}$. and 1 metre.

The river routes of India are the Indus with its tributaries in the Punjab, the Ganges, and the lower Brahmaputra. The Indus

India's River Routes is difficult to navigate and little used by steamers. Occan steamers ascend the Ganges delta to Calcutta, and river steamers can go as far as Allahabad in the heart of northern India.

Burma has a trunk line from Rangoon to Mandalay and the upper valley of the Irrawaddi. The Irrawaddi is easily navigable by steamers as high as Bhamo over 900 miles from the sea.

In the Malay Peninsula a trunk line has recently been opened joining Singapore, Penang, and Bangkok, and the upper Menam valley. The journey from the Siamese capital to Singapore now takes thirty-six hours by land in place of six days by sea. There is no other rail connection with Siam.

China for long has made use of her rivers as the chief highways of the country. In this respect the Yangtse is far the most important. Steamers can ascend 1,000 miles, and Chinese Rivers even ocean-going vessels use the port of Hankow 680 miles from the mouth. Above steamer navigation, in spite of the rapids, the river is used by boats for another 400 miles. The lower reaches of the Yangste are connected by a canal with the Hoang $\mathrm{Ho}$ and Tientsin, the port of Peking on the Pei Ho. The Grand Canal is 660 miles long but in few places 
over $6 \mathrm{ft}$. in depth. It was constructed in the seventh century and has been in use ever since. The Hoang is very swift, and being liable to floods is little used for navigation. The Pei is navigable 50 miles to Tientsin. Tributaries of the Yangste and Sikiang flow in valleys which afford easy communication between Canton and northern China by river and road.

Railway construction in China began late but is now making progress. An important trunk line links Tientsin to Peking and

Railways in China Hankow. From Tientsin a line goes to Mukden, in Manchuria, 522 miles, connecting there with the South Manchurian railway which joins the Siberian system. This makes through rail communication between Europe and China. Tientsin has also direct railway connection over the Hoang flood plains with Shanghai. The Peking-Hankow line is now being extended by the Siang, the Cheling Pass (1,300 ft.), and the Pei valley to Canton. Sections of this line totalling more than half its length have been built from either end.

From Peking a line also goes north-west to Kalgan. Eventually this will be extended along the old tea route to Urga, Kyakhta, and the Siberian railway.

Japan has now an extensive railway system and has lately adopted $4 \mathrm{ft} .8 \frac{1}{2}$ in. in place of $3 \mathrm{ft} .6 \mathrm{in}$. as the standard gauge.

The Siberian railway follows more or less the old trakt or great military road across Siberia and the age old route of the trade between Russia and the Far East. The building

The Siberian Railway was begun in 1891 and finished in 1905. It traverses the southern part of Siberia, crossing all the great navigable rivers which serve as feeders for north and south traffic. Two lines, one from Petrograd and the other from Moscow, join at Omsk on the Irtish after passing through the Urals and traversing the agricultural lands of the northern steppe provinces. Omsk is 1,857 miles from Petrograd and 1,860 miles from Moscow. From Omsk eastward the line, which has a $5 \mathrm{ft}$. gauge, is double-tracked the whole way. At Novo-Nikolaevsk the $\mathrm{Ob}$ is crossed and a branch, known as the Altai railway, turns southward for Barnaul, Biisk, and Semipalatinsk. At Krasnoyarsk the Yenisei is crossed, and soon after the line follows the Angara valley to Irkutsk and Lake Baikal, 1,560 miles from Omsk. Railway wagons and carriages used to cross Lake Baikal on a train ferry, 
and even on rails laid over the ice, but a line built round the southern end at great difficulty now obviates this crossing. Ascending from the lake the line attains its summit level at $3,137 \mathrm{ft}$. and reaches Chita; descending into the Amur basin, it soon divides into two branches. At the junction the double track ends. The original line strikes south-east leaving the Amur valley to cross the high inhospitable plateau of Chinese Manchuria, where it climbs to over $3,300 \mathrm{ft}$. Its terminus is Vladivostok, on the Pacific, 5,400 miles from Moscow. In Manchuria the line throws off a southern branch at Kharbin, which connects with the Chinese railways and leads also to Port Arthur. A later development was the construction of the Amur railway, which leaves the main line at the junction some 60 miles east of Chita and follows an allRussian route to the Pacific, crossing the Amur at Khabarovsk by a bridge a mile and a quarter long and then ascending the Ussuri valley to Vladivostok. By the Amur line the distance from Moscow to the Pacific is nearly 5,500 miles.

The Siberian railway is the one real artery of Siberia and the one link by which the far eastern parts are in touch with Russia. Practically all the settlement of central and eastern Siberia depends on the railway. It has a further value as a quick route between Europe and the Pacific for passengers and mails. In normal times Vladivostok is within 12, Peking within 14 and Yokohama within 16 days of London. By sea the time required from London to Japan is six weeks.

Siberia is well endowed with navigable rivers, but most of them flow from south to north, that is across the narrow belt of settlement and lead to the useless Arctic Ocean. The $\mathrm{Ob}$ Siberia's is navigable by river steamers to Biisk, 2,300 miles
Navigable Rivers from the sea. Its tributary, the Irtish, is navigable to the Chinese frontier. The upper courses of these rivers and their tributaries bear many vessels. The Yenisei has 2,045 miles and the Lena 2,700 miles of navigable waters, both exclusive of tributaries. In eastern Siberia the Amur alone of great Siberian rivers, has an easterly course. With its main tributary the Shilka, it can be navigated for 2,000 miles from its mouth. All Siberian rivers are frozen or unnavigable on account of drifting ice from about November to May. When the ice is firm and smooth it forms an excellent sledge route. 
The construction of a few short canals and the canalization of a few difficult reaches of the rivers would make water-borne traffic possible between European Russia and Lake Baikal.

Two important trunk lines link the Russian railway system with central Asia. The Tashkent line from Moscow passes south of the Urals by Orenburg, over the Caspian steppes and The past the Sea of Aral to Tashkent, a distance of Trans-Caspian
Railway tinues 100 miles to meet the Trans-Caspian line. The Trans-Caspian line runs from Krasnovodsk, on the Caspian Sea, eastward for about 1,200 miles into the heart of the cotton-growing region of Turkestan throwing off a branch to the Afghan frontier from Merv to Kushk. Opposite Krasnovodsk is Baku, the terminus of a line from Moscow about 1,500 miles long. The steamer route between the two railway ports is about 200 miles in length.

The Trans-Caspian railway is part of a possible railway route between Europe and India (p. 185).

In recent years a railway has reached Persia. From Tiflis, on the line from Baku to the Black Sea, a branch strikes south across the Caucasus, and passing through eastern Armenia reaches Tabriz in the north of Persia, about 400 miles north of Baghdad This line has the Russian gauge. 


\section{CHAPTER XIX}

\section{LAND ROUTES (CONTINUED)}

\section{AFRICA}

NEARER to civilized Europe than any other continent, Africa was nevertheless late in coming into the world's trade. With the exception of the Barbary States and Lower Egypt, which belong rather to Europe than to Africa, the continent remained closed to commerce till late in the nineteenth century. In the fifteenth century and earlier there was coastal trade and a little trickled down to the trading ports from the interior (slaves, ivory, gold, ostrich feathers, and so forth), but even now the trade of Africa is small in comparison with her potential wealth.

Many factors, several of them geographical, have contributed to the isolation of Africa. It is a most compact continent, more so than any other except Australia, which is Africa's considerably smaller. No convenient inlets of Geographical Drawbacks

the sea serve as gates to the interior: the rivers though large, are not navigable far from the sea without interruption. African harbours are notoriously bad. The coast opens direct to the ocean with few islands or landlocked seas to reduce the ceaseless swell that breaks in surf upon the shore. Most of the coasts are backed by low plains, often densely clothed in thick and impenetrable forest, reeking with moisture and infested with disease-bearing insects. Beyond this plain Africa rises in jagged steps to the height of the plateau. It is little to be wondered that a continent, whose greater area has a tropical if not equatorial climate, proved difficult to penetrate, uninviting and mysterious. The Barbary States and Lower Egypt are cut off from tropical Africa by the Sahara, while the more attractive temperate south of the continent is separated at least on the west by the Kalahari desert from the Congo region. Tropical Africa is bulwarked by Nature against white invasion. It is true that its very mystery originated tales like those of the wealth of Timbuktu, and the power and splendour of Prester John, both of which lured men on, 
but after all Africa, except for slaves, was only a stopping place and sometimes merely a hindrance, on the road to the East.

With the scramble for Africa and its partition among the powers of Europe in the closing decades of the nineteenth century, came the passing of the Dark Continent and the shedding of light on Africa.

One of the great difficulties in opening Africa to trade was the lack of transport, except human porterage, until railways were introduced. Camels are employed to cross the

Early Trade Difficulties
Sahara but in tropical Africa the inroads of the tsetse fly make it impossible to use horses or cattle as beasts of burden (see p. 26). Finally it must be remembered that the greater part of Africa is peopled by negroes, a race not conspicuous for initiative and enterprize and one which in the stagnation of a tropical climate has made little advance.

The main highways of Africa have always been the rivers. In view of the great distances to be traversed they are likely to remain of first importance. Several of the railways in

\section{Africa's}

Chief Rivers

Africa are built to link navigable stretches and to circumvent rapids, falls, or circuitous detours of the river. The Nile can be navigated as far up as Gondokoro in Uganda, but at low water the cataracts are an impediment. Channels in the delta give access to the seaports. The Zambesi is navigable from the mouth to Tete, a distance of about 250 miles. The Limpopo has only a short navigable stretch and the Orange is unnavigable. In these respects South Africa is poorly endowed, although several of the upper reaches of the Zambesi and its tributaries can be navigated. The Congo system affords a magnificent series of waterways, but unfortunately for the development of tropical Africa navigation is interrupted between the seaport of Matadi, 85 miles from the coast, and Stanley Pool. These difficulties are overcome by a railway 247 miles long from Matadi to Leopoldville. From Stanley Pool vessels can pass up the main stream about 1,000 miles to Stanley Falls, whence there is a railway to Ponthierville, 78 miles. Navigation then continues 200 miles to Kindu and is again interrupted. A railway from Kindu to Kongolo is 217. miles long. Steamers ply for another 50 miles up the Lualaba, the head stream of the Congo, to Kabalo, whence there 
is a railway along the Lukuga valley to Albertville, on Lake Tanganyika, 165 miles. Tugs and barges can ascend the Lualaba from Kabalo some 400 miles to Bukama, the present terminus of the Rhodesian railways. The Ubangi, the main right tributary of the Congo, can be navigated almost to its head within about 250 miles of the navigable headstreams of the Nile.

The Niger can be ascended 500 miles as far as the vicinity of the Bussa rapids. Many of the upper reaches are navigable, notably between Kabara, the port of Timbuktu, and Bamako, whence a railway $\mathbf{3 4 0}$ miles long has been built to the head of navigation on the Senegal, about 400 miles from the seaport of St. Louis at its mouth. An extension of this line to Dakar will soon be completed. The Benue is an important tributary of the Niger, which vessels can ascend as far as Yola. In the wet season practically the whole course of Niger, including the Bussa rapids, can be navigated. The Gambia River is accessible to vessels for 200 miles, a fact which led originally to the foundation of the Gambia as a British possession. The value of the great lakes as waterways must not be overlooked.

Railway construction in Africa in the main takes two forms, lines from the interior to the coast, and lines such as those mentioned above, linking up navigable stretches of African Railway rivers. There is at present no trans-continental
Construetion line. Such a route would have little value for through trade since the whole of the African continent is washed by navigable seas and the Suez Canal has made Africa an island. Several trans-continental routes, however, are projected. The idea strikes the imagination and the scheme portrayed on a map makes a strong appeal to imperial sentiment, even if its practical realization is a little doubtful.

In Egypt there is railway connection from Alexandria and other delta ports to Cairo and up the Nile to Aswan at the first cataract

Egyptian Rallways
(713 miles). The gauge breaks at Luxor. From Aswan to Wadi Halfa, at the second cataract, the navigable Nile takes the place of a railway for 208 miles. From Wadi Halfa rail goes to the third cataract, but a more important line cuts across the desert meeting the Nile again at Abu-Hamed and follows the river to Atbara and Khartum (579 miles) with a branch from Atbara to Port Sudan and Suakin, 
on the Red Sea (305 miles). Beyond Khartum the line continues south to Sennar (168 miles) and then west to El Obeid, a centre of the gum trade in Darfur.

The Egyptian railways are connected through the peninsula of Sinai with the railways of Syria, and westward projections are destined to reach Tripoli and Tunis.

In the east of tropical Africa several disconnected lines bring the interior into relation with the coast. The Abyssinian railway runs from Addis Abbaba, at an altitude of 7,732 ft. The to the French port of Jibuti, on the Gulf of Aden Abyssinian Railway (500 miles). The Uganda railway runs from Port Florence, on Lake Victoria, to Mombasa (584 miles), and the former German line through the Tanganyika territory connects Kigoma near Ujiji on Lake Tanganyika, with Daressalam (778 miles). All these lines involve heavy gradients but are routes of first importance in the development of the interior.

South Africa has a well-developed railway system with trunk lines from Cape Town and east coast ports. Mining activity has stimulated northward extensions to Rhodesia and Railway System the lake region while war was responsible for South Africa extensions in South-West Africa. The railhead of the Rhodesian line is at present at Bukama, on the head stream of the Congo in Belgian Khatanga, 2,700 miles from Cape Town by way of Bulawayo.

A shorter route to Rhodesia from the sea is projected and partly built from Beira, which already has circuitous rail connection with Khatanga, and a line from the navigable Zambesi is approaching completion northwards to Lake Nyassa.

Several lines from the interior reach Atlantic ports north of Cape Town. There are two good harbours in South-West Africa, Lüderitz Bay and Walfish Bay, from each of which a railway runs to a considerable system in the interior. It may prove advisable in the future to build a short route into Rhodesia from Walfish Bay in spite of the obstacle of the Kalahari desert. In Angola a line from Lobito Bay, already built 400 miles to Bihé at an altitude of $5,000 \mathrm{ft}$., is projected to Khatanga, and will eventually form part of a trans-African route. The Congo railways have been mentioned above (p. 190): 
In West Africa the railway lines in the main are complementary to river routes. An important line is from Lagos by Jebba (307 miles) on the River Niger to Kano (700 miles),

West African

Railways in the productive heart of northern Nigeria. Lines on the upper Niger are mentioned above. In French West Africa several lines link the interior with the coast at Dakar, Konakri, etc.

Morocco until recently had no railways, but there is now a considerable length of track projected and partly under construction. A line joins the capital, Fez, to several coast towns and a further extension to the Algerian railways is almost completed. The Algerian railways are mainly coast lines with inland branches in places. The line from Oran to Ain-Sefra and Colomb-Bechar, 465 miles in length, is part of the projected trans-Saharan railway.

The much discussed Cape to Cairo route resolves itself into the best means of connecting Bulawayo with Khartum. Railway from Cape Town to Bulawayo is 1,362 miles. Cape to Combined rail and navigable river route from Cairo Railway
Route Cairo to Khartum is 1,242 miles. There remains a gap of 3,000 to 4,000 miles depending on the route chosen. Considerable difficulties have to be faced, among which the most formidable are the sudd of the Bahr el Ghazel region, the forests of the eastern Congo and the mountainous nature of the central lake region. The obstacle of foreign territory in the way of an all-British line has now been removed. The principal alternative routes suggested are as follows. It will be noted that two of them reduce railway construction by utilizing the lakes as much as possible. (See Geographical Journal, Feb., 1920. Article and map by Mr. Wilson Fox.)

1. From Bulawayo to Bukama by rail, and thence by rail or river to Stanleyville, by rail eastward past Lake Albert to Dufile, Gondokoro, and between the White Nile and the Abyssinian highlands to Sennar and Khartum. This route would entail about 2,500 miles of new railroad construction.

2. From Bulawayo via Salisbury to Beira on the coast, and then north to Malindi, on Lake Nyassa, by steamer to the north end, by rail to Lake Tanganyika, by steamer to Ujiji, by rail via Tabora to the south end of Lake Victoria, by steamer to Entebbe, then rail to Dufile and Khartum as above. This route would entail 
1,600 miles of new railway and would embrace only 800 miles of lake transit.

3. From Bulawayo to Broken Hill and Tanganyika and then as above. This route embraces 500 miles of lake transit, and 1,700 miles of new railways.

The last route, with 5,870 miles between Cape Town and Cairo, is the shortest, and at an average speed throughout of about 12 miles an hour would entail a journey of some seventeen to eighteen days.

The projected flying route from Cairo to Cape Town follows in the main the last of the above routes. The demands of an aerial route in convenient landing places, accessible for Aerial Route supplies and clear of obstructions, are met by much the same considerations as favour railway construction. The projected route is 5,206 miles in length and has forty-three aerodrome sites. The time taken, including delays for one reason or another, will probably be four or five days.

Another projected trans-continental railway is that across the Sahara either from Tangier or from Igli, the present railhead of the line from Oran. Originally projected as a Proposed
Transeontinental route to Timbuktu, when that city still had a

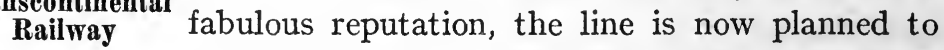
go further east, and passing by Agades to reach Lake Chad and French tropical Africa. A branch is proposed to Gao, on the navigable Niger. The main line is planned to follow the easiest route and one which will link many large oases to one another and to the coast. Its length to Lake Chad would be about 2,000 miles.

The majority of African railways, including those of South Africa, have a $3 \mathrm{ft} .6$ in. gauge but most French lines, and those of former German possessions, have a metre gauge. The Egyptian lines have a $3 \mathrm{ft} .6$ in. gauge from Luxor southward and a $4 \mathrm{ft} .8 \frac{1}{2}$ in. gauge northward. The guage in Morocco is to be $4 \mathrm{ft}$. $8 \frac{1}{2} \mathrm{in}$.

\section{AUSTRALIA}

Australia is largely a desert fringed with fertile lands. Its civilized population is, and probably always will be, mainly peripheral. One of the many peculiarities of the continent is its lack of rivers. The Murray-Darling system comprises the only rivers of any size and their intermittent water supply makes navigation 
uncertain and at best seasonal. With high water the Murray is navigated as far as Albury, about 1,400 miles from the mouth. The Darling can be ascended in favourable conditions for 1,200 miles.

The railways of Australia are chiefly lines linking mining, pastoral, and agricultural regions with seaports. Those in New South Wales radiate from Sydney and those in Victoria from

Australian

Railways

Melbourne. Each State originally chose its own gauge regardless of the probability of interstate connections. Now that trunk lines have been built the inconvenience and expense of the breaks in gauge are considerable. Suggestions for the unifications of the gauge throughout the Commonwealth have made little progress. Interstate rivalry seems to prevent any one of the three chief gauges being adopted. Eventually $4 \mathrm{ft}$. $8 \frac{1}{2}$ in., the New South Wales and the Federal gauge, will probably become the standard. All the State capitals are now linked together by railway and lines are under construction to Canberra, the new Federal capital which is also to have a line 135 miles long, to its own seaport in Jervis Bay. From Brisbane to Adelaide via Sydney and Melbourne is 1,790 miles. From Adelaide the line continues to Port Augusta, at the head of Spencer Gulf, crossing on the way the important mineral route from Broken Hill to Port Pirie. At Port Augusta begin two long trans-continental lines, one to Kalgoorlie, Perth, and Fremantle, which is complete, a distance of over 1,400 miles, and the other to Oodnadatta, 478 miles, but planned eventually to cross the interior to Port Darwin in the Northern Territory.

The southern trans-continental line which has a gauge of $4 \mathrm{ft}$. $8 \frac{1}{2}$ in., brings the distant south-western corner of Australia into touch with the rest of the Commonwealth with which its former relations were solely by sea. It also brings eastern Australia two days nearer to Europe for mails and passengers if these are landed at Fremantle, to continue their journey overland.

The proposed line from Port Darwin to Adelaide would help to open to stock-grazing the lands of the artesian basin and the Macdonnell Ranges. It already forms an im-

Port Darwin to Adelaide Project portant stock route between Oodnadatta and the south coast. By means of the completed line the Northern Territory would lose its present isolation from the other parts of the Commonwealth. Its advocates 
maintain that the completion of this trans-continental route would put Adelaide within seventeen days of London via the Siberian and Chinese railways and steamer from Hong Kong. These advantages are more likely to be gained by the construction of a line from Port Darwin through the western part of Queensland to the New South Wales railway system. The extension of several of the disconnected Queensland lines would meet this trunk line.

Railway construction on the interior plains and plateaus of Australia finds its chief difficulty in the drought conditions, but the lines from the east coast to the interior have severe gradients.

New Zealand has a trunk line practically from north to south of both islands. 


\section{CHAPTER XX}

\section{LAND ROUTES (CONTINUED)}

\section{NORTH AMERICA}

BEFORE the advent of railways water routes tock a great part in transportation in North America and they are still of much importance. The early history of colonization of the continent centred round the valleys of the St. Lawrence, Hudson, and Mississippi.

The great lakes linked to one another and the St. Lawrence by canals are busy waterways with an enormous volume of traffic in iron-ore, wheat, etc., during seven or eight months

North America's of the year. The Erie-Mohawk-Hudson water Water Routes route links the lake system to the United States seaboard, and is joined to the St. Lawrence by the Champlain Canal. To improve further the water connections with the western plains it is proposed to dig a ship canal from Georgian Bay, on Lake Huron, to Ottawa whence the Ottawa River is navigable to the St. Lawrence. From Georgian Bay to Montreal the distance would be some 400 miles, but only about 40 miles of canal would be required, natural waterways serving the rest of the route. The Georgian Bay canal, planned to be $20 \mathrm{ft}$. deep, would allow sea-going vessels to reach the great lakes with ease and would save 300 miles on the present route by Lake Erie.

The Mississippi mouth is blocked by a delta but the river, although liable to heavy floods and very prone to shift its channels, is navigable by light draught river steamers as far as St. Paul, while its tributary, the Ohio, is navigated into Pennsylvania. The Missouri is subject to floods to a greater extent than the other tributaries but can be navigated almost to the foot of the Rockies, not many miles from the Canadian frontier. Several of the other tributaries of the Mississippi are useful water routes: the whole river system furnishing about 16,000 miles of navigable rivers. As a rule navigation is interrupted for several months of the year. Several other North American rivers are of minor and local value as waterways. Of these the Columbia, on the Pacific coast, is 
open to vessels for some 250 miles. In Alaska the Yukon is the main route to the goldfields and is navigable for about 1,500 miles during a few months of summer.

A number of trunk railways cross the continent from Atlantic to Pacific. They have importance not only in joining the populated centres of east and west but serve as links in routes Trunk Railways from Europe to Japan, China and Australasia. The first through route in the United States was opened only fifty years ago, and in Canada less than forty.

The chief physical obstacles controlling the course of transcontinental railways are the rugged Appalachian mountains in the east, the great lakes in the north-east of the plains, and the numerous ranges of the western cordilleras. Routes wind considerably in crossing the western ranges in taking advantage of the easiest passes, while gaps in the northern Appalachians, decide the course of the lines to the Atlantic seaports. The great lakes necessitate a southward deviation of several routes.

Canada has three trans-continental railways. Owing to the closing of the waterways in winter these and other lines are vital to the development of the country. As through routes to the Pacific the Canadian lines are shorter than those of the United States. In proximity to Europe and Asia their Atlantic and Pacific termini also have an advantage over the ports of the United States. For through traffic to Australia and New Zealand the United States lines, preferably extended to Mexican ports, have the advantage.

The Canadian Pacific railway runs from Halifax and St. Johns, ice-free ports in winter, across United States territory in Maine to Montreal. From Montreal it ascends the

Canadian-

Railway Ottawa valley, passes north of the great lakes and reaches Winnipeg, which, with lakes and barren lands to the north and the United States frontier to the south, lies at a nodal point of all east and west traffic. From Winnipeg the line crosses the plains via Regina, to the Rockies, dividing at Medicine Hat, the main line going north-west to the Kicking Horse Pass (5,300 ft.). It is proposed to save much of the climb to this pass by a 16-mile tunnel. From the Rockies the line passes through the Selkirks and at length by the Fraser valley to Vancouver (3,595 miles from Halifax). By following the Intercolonial line from Halifax through New Brunswick and along the 
St. Lawrence to Montreal it is possible to remain on Canadian territory by adding about 200 miles to the length of the route.

The Grand Trunk Pacific railway starts at Moncton, at the head of the Bay of Fundy on the line between Halifax and St. John.

It follows a circuitous route to Quebec, in order

Grand Trunk to remain on Canadian territory, and then goes Pacifie Railway across country to Winnipeg. From there it strikes north-west into the great plains via Edmonton to the Yellowhead Pass (3,700 ft.), and thence by a somewhat devious route following various valleys to Prince Rupert, on the Pacific, the most northerly Canadian port. From Halifax to Prince Rupert is 3,746 miles. Lastly, there is the new Canadian Northern railway which, when complete, will afford a route from Quebec and Montreal via the great lakes to Winnipeg, Saskatoon, Edmonton, the Yellowhead Pass and Vancouver. Several lorg sections are already constructed.

The Hudson Bay railway is now nearing completion. It runs from the Canadian Northern line, in the heart of the wheat region with connections from Winnipeg, Regina, and Hudson Bay Saskatoon via Le Pas to Port Nelson on Hudson
Railway

Bay, a distance of 510 miles. The value of this route for wheat export has already been discussed (p. 168).

One other Canadian railway must be mentioned. That is the Yukon railway from the United States port of Skagway in the Alaskan "pan handle" to Whitehorse, on the navigable Yukon. The line climbs over the White Pass at a height of 2,897 ft. Of its 120 miles the first few are in United States territory.

The United States has a highly developed railway system with a total mileage of over 266,000 miles. The standard gauge, like that of Canada, is now $4 \mathrm{ft}$. $8 \frac{1}{2}$ in.

United States From New York a line follows the HudsonRailway System Mohawk valley through the region of the great lakes, by Buffalo and Detroit, to Chicago (980 miles). Chicago is the starting point of through lines north-west of St. Paul, with connections to Winnipeg (868 miles), and Montreal (850 miles), through the western cordilleras to Puget Sound and Seattle (1,911 miles), and west via Omaha, Ogden, and the Great Basin to San Francisco (2,275 miles). Other lines go north-east 
to Toronto and Montreal (850 miles) and south by the Mississippi valley to New Orleans (912 miles). Chicago is also linked direct with Philadelphia and New York by a route which takes the Susquehanna valley through the Appalachians. By this route the distance from New York is about 70 miles less than by Buffalo. From Philadelphia and Baltimore there is a more southerly transcontinental route. It crosses the Appalachians by the Potomac valley and reaches St. Louis, the great focus of the Mississippi navigation after a distance of 920 miles from Baltimore. Thence the line goes west by Kansas City, Sante Fé, and the arid lands of Arizona to Los Angelos on the Pacific (1,917 miles), and down the San Joaquin to San Francisco (2,395 miles from St. Louis).

Lastly there is the most southerly trunk route from Baltimore and Washington south-west to New Orleans and therice along the gulf plains and skirting the Mexican frontier to Los Angelos. At several places on this line there are connections with the railways of Mexico most notably at Laredo and El Paso.

Mexico is not ill-provided with railways despite difficulties in construction between plateau and coast, but many lines suffer from gaps in construction which lessen their value.

Mexican Railways

Lines focus on the mining towns of the north, on Mexico City, and on the east-coast ports. Several west-coast ports have rail connections with the United States but few are linked to the plateau and east coast of Mexico. The route from Topolobampo north-east across Mexico and the United States via Presideo, on the frontier, and St. Louis to New York, which lacks two stretches of about 100 miles each, would afford a link in a quick route from Europe to Australasia but one which has lost importance since the Panama Canal was built. The Tehuantepec railway from Salina Cruz to Puerto Mexico, across the narrow isthmus of that name, was the forerunner of the Panama Canal and still has some value.

tral American lines merit no special notice, except the short Panama railway from sea to sea, near the route of the canal. There are many gaps in the proposed trunk line along

Central

American Railways the isthmus between North and South America. Heavy gradients, volcanic activity, and luxuriant vegetation are all hindrances to railway construction in Central America. 


\section{SOUTH AMERICA}

South America is a compact and in the main a tropical country. The mountains which fringe its entire western coast and the plateau of Brazil in the east limit water routes to a few great rivers which flow to the Atlantic, but unlike the great rivers of Africa, these are navigable for long distances from the sea. The Amazon is the most important in length of waterways. Its system comprises 50,000 miles of safe navigation in the wet season and some 20,000 in the dry season. Ocean-going vessels ascend at all seasons to Iquitos on the Maranon, or Upper Amazon in Peru, 2,500 miles from the Atlantic. Under favourable conditions they can go 500 miles further up-stream. In the wet season occangoing vessels can ascend the Madeira, the chief tributary of the Amazon, to Santo Antonio, 1,500 miles from the sea, where rapids close the navigable channel. These rapids are circumvented by a railway 226 miles long above which the river has another 500 navigable miles to Santa Cruz. About 400 miles of railway eastward from Santa Cruz would link the navigable system of Amazon and Parana. Manaos, at confluence of the Rio Negro, another navigable tributary of the Amazon, is an ocean port although some 800 miles from the sea. The Tapajoz is navigable 200 miles, the Purus about 1,000 miles. Many other of the Amazon tributaries will probably prove to be of use for river steamers when adequately charted. Excellent as the Amazon waterways are they are still of relatively little use because they lead through a densely forested swampy region scantily populated, little developed and largely unexplored.

The Orinoco of Venezuela is another long waterway. It is navigable for sea-going vessels for about 150 miles, and for river steamers for another 650 miles. The Meta, its Waterways of chief tributary, is navigable for some 200 miles.
South America In Colombia the Magdalena and the Atrato both have long navigable stretches. It is said that a canal of a few hundred yards between the Atrato and the San Juan would complete a waterway between the Atlantic and Pacific.

The most useful river system in South America is the Parana system since much of it lies in temperate lands well suited for agriculture and cattle ranching. It provides a waterway into the heart of the Argentine, Paraguay, Uruguay, and southern Brazil. 
Rosario, 240 miles above Buenos Aires, is a busy seaport and large steamers can ascend another 100 miles to Santa Fé. River steamers ply as far as Ascuncion, the capital of Paraguay, 940 miles above Buenos Aires, and Concepcion. The upper Parana is navigated as far as Posados. On the Uruguay sea-going vessels reach Paysandu and river steamers go to Salto and beyond.

Lastly the Rio Negro, in Patagonia, may be mentioned. It traverses a good sheep country and is navigable for nearly 300 miles.

Railway construction in South America has to face the physical obstacles of mountains, jungle, and swamp. Divided political control is another hindrance to the conSouth
Ameriean
Railways struction of trunk lines and shows its influence in the many different gauges of the continent. The metre gauge is commonest on the whole, but South American railways have been constructed on no less than fourteen gauges ranging between $5 \mathrm{ft} .6$ in. and $1 \mathrm{ft} .8$ in. Population being chiefly peripheral, railways (like in Africa) are mainly useful in linking seaports to their hinterlands, but the necessity for joining the distant west coast to Atlantic seaports has not been wholly obviated by the construction of the Panama Canal. The pampas of the Argentine is the only region well served by railways : they radiate on Buenos Aires and are an expression of rapid settlement of rich pastoral and agricultural lands.

So far the only trans-continental railway in South America is between Buenos Aires and Valparaiso. The distance is 894 miles of which 650 miles are on the Argentine plain and on the Chilean lowlands. The railway climbs in the Andes to a height of $10,338 \mathrm{ft}$. where it runs under the Uspallata Pass in a 2-mile tunnel. In the Andes the gauge is a metre: on the plains to east and west, $5 \mathrm{ft} .6 \mathrm{in}$.

A line, which is nearly complete across the continent, is that from Buenos Aires north-west ward by Rosario and Tucuman to Jujuy (940 miles), skirting the Andes to the west and the wild Chaco on the east. A stiff gradient necessitating the use of rack leads to the Argentine frontier, whence a short gap of some 120 miles is being constructed to join the Argentine system with the railways of the Bolivian and Peruvian highlands and their coastal connections to the west.

Another trunk line of importance is that from Monte Video northward with connection from Buenos Aires. This line traverses 
the valuable southern provinces of Brazil to Sao Paulo and Rio de Janeiro (1,986 miles). From Rio de Janeiro a line runs north (625 miles) to the head of inland navigation on the Sao Francisco. About 675 miles of river navigation lead to the railhead of a line, 360 miles long, to the seaport of Bahia.

Chile is the only other South American state which has a considerable railway system. A longitudinal line extends from Pisagua, in the north, to Puerto Montt in the south, a distance of 2,000 miles: there are connections to all the principal ports. Several breaks in gauge are a hindrance to through traffic. 


\section{APPENDIX}

\section{REFERENCES TO BOOKS}

THIs list, in addition to some of the chief works consulted, contains mainly volumes that will prove useful for reference. It is, of course, far from exhaustive, and in the main cites only volumes in English.

Handbook of Commercial Geography. G. G. Chisholm (1908)

Industrial and Commercial Geography. J. Russell Smith (1913).

Physical and Commercial Geography. H. E. Gregory, A. G. Keller, and A. L. Bishop (1910).

Economic Geography. J. Macfarlane (1913).

Atlas of the World's Commerce. J. G. Bartholomew and G. G. Chisholm (1907).

An Atlas of Economic Geography. J. G. Bartholomew and L. W. Lyde (1914).

An Atlas of Commercial Geography. F. Allen and D. A. Jones (1913). Mercantile Marine Atlas. G. Philip (1916).

"Times" Survey Atlas of the World. J. G. Bartholomew (1920-21). The International Geography. H. R. Mill (1907).

The Oxford Survey of the British Empire. A. J. Herbertson and O. J. R. Howarth (1914).

The Continent of Europe. L. W. Lyde (1913).

Physical Geography. M. I. Newbigin (1912).

Soils. E. W. Hilgard (1907).

Influences of Geographic Environment. E. C. Semple (1911).

Geographic Infuences in American History. A. P. Brigham (1903)

L'Homme et la Terre. E. Reclus (1905-8).

La Géographie Humaine. J. Brunhes (1911).

Man and his Work. A. J. Herbertson (1909).

Geography and World Power. J. Fairgrieve (1915).

Our Social Inheritance. P. Geddes and V. Branford (1919).

Handbook of Climatology. J. Hann (1903).

Climate and Weather. H. N. Dickson (1911).

Climate: especially in Relation to Man. R. de C. Ward (1918).

Climate and Civilization. E. Huntington (1915).

Plant Geography. A. F. W. Schimper (1903).

The Geography of Plants. M. Hardy (1920).

Animal Geography. M. I. Newbigin (1913).

Agriculture in the Tropics. J. C. Willis (1909).

The Commercial Products of India. Sir George Watt (1908).

The Mineral Industry during 1917. G. A. Roush (1918).

Mines and Minerals of the British Empire. R. Stokes (1908).

The Dawn of History. J. L. Myres (1911). 
A Historical Geography of the British Colonies. Sir C. P. Lucas (1913). The Far Eastern Tropics. A. Ireland (1905).

The Colonization of Africa. Sir H. H. Johnston (1913).

Tie Negro in the New IVorld. Sir H. H. Johnsten (1910).

The Story of Africa and its Explorers. R. Brown (1895).

The Origin and Growth of English Colonics. H. E. Egerton (1904).

Human Geography in Western Europe. H. J. Fleure (1918).

Seaways of the Empire. A. J. Sargent (1918).

The Panama Canal. J. Barrelt (1913).

The Scottish Geographical Magazine. Quarterly ; formerly monthly.

The Geographical Review (New York). Monthly.

The Geographical Joumal. Monthiy.

The Board of Trade Journal. Weeily.

The Statesman's Year Book. Annusl.

The Canada Year Book: The Year Book of the Commonwealth of Australia; and other similar annuals.

Diplomatic and Consular Reports. Various.

Shipping World Year Book.

British Association Handbooks. Various towns and countrics. 


\section{INDEX}

Acclimatization, 105-110

Afforestation, 21

Africa, Arab influence on, 23, 140, 151-152

- Portuguese influence on, 23, 145-146, 151-152

- , slave trade in, 149-152

_. trade difficulties with, 189-190

Agriculture and civilization, $\mathrm{x}, 22$, 89-91, 94, 113

Alcohol as fuel, 81

Aluminium, 66

America, Portuguese influence on, 146

- , slave trade with, 149-152

_- Spanish influence on, 147-149

Animals, domestic, 31-33, 56-60

- hostile, 25-26

Arab traders, 140-141

Architecture and climate, 11-12

Asbestos, 70

Asiatic migration, see Emigration, Asiatic

BARLEY, 38

Barter, 138

Beef, see Meat production

CAmel, 118, 140

Canals, 125-130

Canal, Caledonian, 130

-.., Erie, 126

- - Forth and Clyde, 130

- Grand (China) 185

- Huddersfield, 127

$\longrightarrow$ Kiel, 130

- Manchester Ship, 129

- Panama, 105, 128-129

-, Panama, routes, 173-178

_, "Soo," 126

170, 177

, Trollhättan, 127

- Welland, 126, 127

Caste system, 101

Cattle breeding, 32-33, 56-57

Chromium, 64

Climate, 3-8

-, influence of, 9-15, 163-164

Coal, 75-79

Coaling stations, 134, 177
Cocoa, 46-47

Coffee, 44-45

Colonies, Greek, 141

—_, kinds of, 110-111

- , Phoenician, 139

Colonization, 106-116

Conquest of Nature, xi

Copper, 64-65

Copra, 44

Cotton, 51-53

Crops, origin of, 22-23

DAIRY farming, 33, 56-57

Diamonds, 71

Donkeys, 60

Drang nach Osten, 154

Dutch voyagers, 146

Elephant, 118

Emigration, 111-116

—-, Asiatic, 97-103, 115-116

FISHERIES, 28-30

Fishing, 88

Flax, 44, 53

Food supply and population, 19, 87-92

$\longrightarrow$, trade in, 156

- values, 34-35

Forests, 19-21

Fox farms, 27

Fruits in commerce, 24

Fuel, 75-81

Fur trading, 27

GEOGRAPHy, functions of, xiii

-, economic, xi-xii

Geographical inertia and momentum, 84-85, 129

Gold, 68-69

Graphite, 69

Great circle routes, 132, 171, 172, 173

Gregariousness, 11, 157

Gypsum, 70

Health and climate, 11

Hemp, 54

Horns, 57

Horses, 31-32, 59-60, 118

Hunting, 27, 31, 88 
INDUSTRIAL crops, 49-55

towns, 161

India, European influence on, 72, 101, 145-147

Insect pests, 26, 47, 105

Iron, 61,64

Irrigation, 90-91

JUTE, 54

LABOUR, alien, 99-101

Asiatic, 97-103

- forced, 97

- imported, 97-98, 101 , native, 95-97

- skilled, 84

Land forms, 1

Languages of commerce, 137

Lead, 63

Linseed, 44, 53

MaI7e, 22, 39-40

Malaya, Dutch influence on, 146

- Portuguese influence on, 145

Manganese, 64

Manufactures and climate, 13

- development of, 155

- location of, $13,73-74,81-86$, 92-93

Meat production, 32, 56-57

Mental life and climate, 13-15

Mercury, 67

Milk production, 33, 56

Millet, 41

Mining populations, 92-93

- railways, 122

- regions, 62

- towns, 92, 162

Molybdenum, 67

Mutton, see Meat production.

Nationality, xiv-xv

Negroes in America, 149-150

Negro labour, 96, 99 ; see also Slave trade

- republics, 149, 152

Nickel, 64

Nitrates, 70

North-east passage, 153

North-west passage, 152

OATS, 38

Oil, mineral, see Petroleum

$\longrightarrow$, vegetable, 43-44

PAPER fibres, 55

Pasturage, 31-32, 58, 88-89

Pearls, 31, 71
Petroleum, 79-81

Phoenician trade, 139

Phosphates, 70

Pigs, 59

Platinum, 67

Population, demand for, 94, 102

- density of, 87-94, 157, 161-162

Portuguese voyagers, 144-146 ; see also Slave trade

Postal services, 135-136

Poultry, 60

Power, animal, 72

-, electric, 73-74

- human, 72

-, mechanical, 72-31

—, water, 73-75

- wind, 72

Pressure, atmospheric, 4-5

QUicksilver, 67

RACES, xiii-xiv

and climate, 14-15, 104-112 , extinction of, 100

Railways, 121-123

-, African, 190-194

- Asiatic, 184-188

- Australian, 195-196

- Baghdad, 154, 184

- Cape to Cairo, 193-194

- European, 181-183

- gauge of, $123,183,184,185$, $186,194,195,199,202$

-, North American, 197-198

-, South American, 201-203

- Trans-Saharan, 191, 193, 194

- Trans-Siberian, 122, 186-187

Rainfall, 5-6

Reindeer, 119

Rice, $40-41$

Rivers, African, 190-191 Asiatic, 184-185, 187

-, Australian, 194-195

-, European, 179-180

- international, 124-125, 179-

180

-, North American, 197-198

-, South American, 201-202

- transport by, 123-125

Roads, 119-120

"Robber economy," 61

Rocks, 2

Routes, African, 189-194

-, Asiatic, 183-188

- Atlantic, 166-169

-, Australian, 194-196

- caravan, 140, 183

-, Eastern, 168-171. 
Routes, European, 179-183

-, North American, 197-200

-, Pacific, 172-178

- , sailing ship, 12, 163-165

- South American, 201-203

- steamer, 132-133, 165-178

Rubber, 49-50

Rye, 39

SAILING ships, 131

- , routes, $12,163-165$

Seamanship, 29, 142, 144

Seaports, origin and growth of, 159161

Self-determination, $\mathrm{xv}$

Sheep, 57-59

Ship-building, 83

Shipping, 131-135

Silk, 54-55

Silver, 67-68

Skilled labour, 84

Slave trade, 95-96, 140, 149-152

Soils, 2-3, 18

Spanish voyagers, $147-149$; see also Slave trade

Spice trade, 143, 145, 146

Steamships, 132-135

Steel, 64 routes, $165-178$

Sugar, 41-43

Sulphur, 69

TEA, 45-46

Telegraphs, 136

Temperament, national, 14

Temperature, 3-4

Timber, 19-21

Tin, as fuel, 75

Tin, 61,65

Tobacco, 48

Towns, origin and growth of, 157-162

Trade, African, 139-140, 144-147, 189-190

- Arab, 140-141

- Eastern, 141-149

- Greek, 141

- Mediterranean, 139-144, 153

- modern, nature of, 153-156, 166-178
Trade, oceanic, $144,-149$

- , origin of, 138-139

-, Phoenician, 139

- Portuguese, 144-146

- Roman, 142 routes; see Routes and climate, 12-13 , slave, 95-96, 140, 149-152 , spice, 143, 145-146 , Venetian, $143,-144$

Trading stations, British, 147, 150

—— Dutch, 146

-

- - Greek, 141 - $\longrightarrow$ Phoenician, 139

150

- Portuguese, 145-146, 149,

Traditions, xii

Train-ferries, 134, 180

Tramways, 121

Transport, aerial, 135, 194

- animal, 31-32, 60, 118-119

- canal, 125-130

166

economy in, 85, 131, 133, 165-

-, human, 117-118

- motor, 120

- ocean, 130-135

- orography, and, 117

-, rail, 121-123

-, river, 123-125

-, wheeled, 119-123

Trees and climate, 17

VANADIUM, 64

Vegetation, 16-20

Vine, 47-48

WATER power, 73-75

Whaling, 30

Wheat, 35-38

Winds, 4-5

Wine, 47-48

Wood : see Timber

Wood pulp, 55

Wool, 58-59

ZINC, 65 


\section{PITMAN'S}

\section{BUSINESS HANDBOOKS}

AN ABRIDGED LIST OF PRACTICAL GUIDES FOR :: BUSINESS MEN AND ADVANCED STUDENTS ::

\section{B00K=KEEPING AND ACCOUNTS}

ADVANCED ACCOUNTS. A Manual of Advanced Book-keeping and Accountancy for Accountants, Book-keepers and Business Men. Edited by Roger N. Carter, M.Com., F.C.A., Lecturer on Accounting at the University of Manchester. In demy 8vo, cloth gilt, $988 \mathrm{pp} ., 10 \mathrm{~s} .6 \mathrm{~d}$. net. AUDITING, ACCOUNTING AND BANKING. By FraNk Dowler, A.C.A. and E. MARDINOR HARRIS, Associate of the Institute of Bankers. In demy 8vo, cloth gilt, 328 pp., 7s. 6d. net.

THE PRINCIPLES OF AUDTTING. A Practical Manual for Advanced Students and Practitioners. By F. R. M. DE PAULA (of the firm of De Paula, Turner, Lake \& Co.), F.C.A. In demy 8vo, cloth gilt, 224 pp., 7s. 6d, net.

ACCOUNTANCY. By F. W. Pixley, F.C.A., Barrister-at-Law, Ex-President of the Institute of Chartered Accountants. In demy 8vo, cloth gilt, 318 pp., 78. 6d. net.

AUDITORS: THEIR DUTIES AND RESPONSIBILITIES. By the same Author. Eleventh Edition. In demy 8vo, cloth gilt, 732 pp., 21s. net.

COST ACCOUNTS in Principle and Practice. By A. Clifford Ridgway, F.C.A. In demy $8 \mathrm{vo}$, cloth gilt, with 40 specially prepared forms, $5 \mathrm{~s}$. net.

COMPANY ACCOUNTS. By ARThur Coles, F.C.I.S. With a Preface by Charles Comins, F.C.A. In demy 8vo, cloth gilt, 356 pp., 7s. 6d. net.

DICTIONARY OF BOOK-KEEPING. By R. J. PORTERs. In demy 8vo, 780 pp., 7s. 6d. net.

MANUFACTURING BOOK-KEEPING AND COSTS. By George Johnson, F.C.I.S. In demy 8 vo, cloth gilt, 120 pp., 5s. net.

GOLD MINE ACCOUNTS AND COSTING. A Practical Manual for Officials, Accountants, Book-keepers, etc. By G. W. TAIT. In demy 8 vo, cloth gilt, $5 \mathrm{~s}$. net.

THE ACCOUNTS OF EXECUTORS, ADMINISTRATORS AND TRUSTEES. With a Summary of the Law in so far as it relates to Accounts. By William B. Phillips, A.C.A. (Hons. Inter. and Final), A.C.I.S. Fourth Edition, Revised. In demy $8 \mathrm{vo}$, cloth gilt, 150 pp., 5 s. net.

PRACTICAL BO0K-KEEPING. By GEo. JoHnson, F.C.I.S. In crown 8vo, clcth, 420 pp., 6s. net.

RAILWAY ACCOUNTS AND FINANCE. Railway Companies (Accounts and Returns) Act, 1911. By AlleN E. Newhook, A.K.C. In demy 8vo, cloth gilt, 148 pp., 5s. net.

DEPRECIATION AND WASTING ASSETS, and their treatment in computing annual profit and loss. By P. D. LEAKE, F.C.A. In demy 8vo, cloth gilt, 257 pp., 12s. 6d. net

G $w-1$ 
ACCOUNTIN. By S. S. DAwson, F.C.A. and R. C. DE Zoucre, F.C.A. In demy 8 vo, cloth gilt, 290 pp., 10s. ed. net.

MANUAL OF COST ACCOUNTS. By JULIUS LUNT, A.C.A. (Hons.). In demy 8vo, cloth gilt, 124 pp., 6s. net.

\section{BUSINESS TRAINING}

ECCTURES ON BRITSH COMMERCE, including Finance, Insurance, Business and Industry. By the RT. HON. Frederick Huth JAexson, G. Armitage-Smith, M.A., D.Lit., Robert Bruce, C.B., Sir Douglas Owen, W. E. Barling, J. J. Bisgood, B.A., Allan Greenwell, F.G.S., Iames Graham. With a Preface by the Hon. W. Pember Reeves. In demy 8vo, cloth gilt, 295 pp., 7s. 6d, net.

IIE THLOEY AND PRACTCE OF COBDERCE. Being a Complete Guide to Methods and Machinery of Business. Editcd by F. HEELIS, F.C.I.S., Assisted by Specialist Contributors. In demy 8vo, cloth gilt, 620 pp., with many facsimile forms, 6s. net. Also in 2 vols., each, price 3 . 6.1. ret.

THE PRINCIILS AND PRACTCE GF COMBERCE. BY JAMES STEPHENson, M.A., M.Com., B.Sc. In demy 8 vo, cloth gilt, 650 pp., with many facsimile forms, $10 \mathrm{~s}$. Ed. net.

THE PRINCIPLES AND PRACTICE OR CORMERCIAL CORRESPONDENCE. By the same Author. In demy 8vo, 320 pp., 7s. 6d. net.

THE PRICORLES OF COMIERCLAL MSTORY. By the same Author. In demy 8vo, 279 pp., 73. 6l. net.

THE PRINCIPLS AND PRACICE OF COMMERCIAL ARITHIETIC. By P. W. Norris, M.A., B.Sc. (Hons.). In demy 8 vo, 452 pp., 7s. 61. net.

MODERN BUSINRSS AND ITS METHODS. A Manual of Business Organization, Management and Office Procedure for Commercial Students and Business Mien. By W. Campbell, Chartered Secretary. In crown 8vo, cloth, 493 pp., 7s. Cd. net. Also in 2 vols., each 8s. 6u. net.

\section{INSURANCE}

INSURAYCE. A Practical Exposition for the Student and Business Man. Ey 'i. E. Young, B.A., F.R.A.S. With a Practical Section on Workmen's Compensation Insurance, by W. R. STRong, F.I.A.; and the National Insurance Scheme, by VyVyan MARR, F.F.A., F.I.A. Third Edition. Revised and Enlarged. In demy 8vo, cloth gilt, 440 pp., 10s. \&l. r.ct.

INSURANCE OFFICE ORGANISATION, MANAGENENT, AND ACCOUNTS. By T. E. Young, B.A., F.R.A.S., and Richard Masters, A.C.A. Second Edition, Revised. In demy $8 \mathrm{vo}$, cloth gilt, $150 \mathrm{pp}$., Es. net.

TALIS ON INSJPANCE LAW. By Jos. A. WATSON, B.Sc., LL.B. In crown 8 vo, cloth, 140 pp., 5s. net.

\section{ORGANISATION AND MANAGEMENT}

OFFICR OPGANISATION AND MANAGEMENT. Including Secretarial Work. By LAwRence R. Dicksee, M.Com., F.C.A., and H. E. Blain. Late Tramways Manager, County Borough of West Ham. Fourth Edition, Revised. In dciny 8vo, cloth gilt, $314 \mathrm{pp}$., "s. 6f. net.

COUNTING HOUSE AND FACTORY ORGANISATION. A Practical Manual of Modern Methods applied to the Counting House and Factory. By J. Girmour Williamson. In demy $8 \mathrm{vo}_{2}$ cloth gilt, $182 \mathrm{pp}$., 6s. net. 
FILING SYSTElis. Their Principles and their Application to Moderi Office Requirements. By EDWARD A. COPE. In crown 8vo, cloth gilt, $200 \mathrm{pp}$. with illustrations, 2s. 6l. net.

INDUSTRIAL TRAFFIC MANAGEMENT. By Geo. B. Lissenden, A uthnr of "Railway (Rebates) Case Law," elc., etc. With a Foreword by CHARLeS E. Musgrave, Secretary, London Chamber of Commarce. In demy 8vo, cloth gilt, 260 pp., 7s. 6d. net.

MOTOR ROAD TRANSPORT FOR COMHEEAII PURPGGRS. By JOHN Phillimore. With an Introduction by Sir H. P. MAYBury, K.C.M.G., C.B. In demy $8 \mathrm{vo}$, cloth gilt, 216 pp., 12s. 61. net.

THE PSYCHOLGGY OF MANAGEHENT. By L. M. Gilbretr. In demy 8 vo, 354 pp., 7s. 6d. net.

EMPLOYMENT' MANAGEMENT'. Compiled and edited by DANIII BloomField. In demy 8vo, 507 pp., 8s. 6u. net.

LECTURES ON INDUSTRIAL ADHINISTRATION. Edited by B. MUScio, M.A. In crown 8vo, cloth, 276 pp., 6. net.

OUTLINES OF INDUSTIIAL ADMINISTRATIOY. By R. O. HERTORD, H. T. Hildage, and H. G. Jenkins. In demy 8vo, cloth gilt, 124 pp., 6s. net.

INDUSTRIAL CONTROL. By F. M. LAwson. In demy 8vo, cloth gilt, 130 pp., 8s. 6d. net.

MUNICIPAL OFFICE ORGANISATION AND MANAGEMENT. Edited by WILliam BAteson, A.C.A., F.S.A.A. With contributions by eminent authorities on Municipal Work and Practice. In crown 4to, half-leather gilt, with about 250 diagrams and forms, 503 pp., 25s. net.

CLUBS AND THEIR MANAGENENT. By Francis W. PixLeY, F.C.A., Barrister-at-Law. In demy 8vo, cloth gilt, 240 pp., 78. 6d. net.

SOLICITOR'S OFFICE ORGANISATION, MANAGEHENT, AND ACCOUNTS. By E. A. Cope and H. W. H. Roeins. In demy 8 vo, cloth gilt, 176 pp., with numerous forms, 5s. net.

COLLIERY OFFICE ORGANISATION AND ACCOUNTS. By J. W. INNES, F.C.A., and T. Colin CAMPBELL, F.C.I. In demy 8vg, 6s. net.

DRAPERY BUSINESS ORGANISATION AND MANAGEMENT. BY J. ERNEST BAYLEY. In demy 8vo, cloth gilt, 300 pp., 7s. 6d, net.

GROCERY BUSINESS ORGANISATION AND HANAGEHEN'. By C. L. T. BEECHING. With Chapters on Buying a Business, Grocers' Office Work and Book-keeping, etc., by J. A. SMART. Sccond Edition. In demy 8vo, cloth, 160 pp., $6 s$. net.

THE HISTORY, LAW, AND PRACTICE OF THE STOCK EXCHANGE. By A. P. Poley, B.A.. Barrister-at-Law; and F. H. CARruthers Gould. Third Edition, revised. In demy $8 v o$, cloth gilt, 348 pp., $7 \mathrm{~s}$. 6d. net.

\section{SHIPPING}

SHIPPING OFFICE ORGANISATION, MANAGEMENT, AND ACCOUNTS. A comprehensive Guide to the innumerable details connected with the Shipping Trade. By Alrred Calvert. In demy 8vo, cloth gilt, 203 pp., with numerous forms, $6 \mathrm{~s}$. net.

THE EXPORTER'S HANDBOOK AND GLOSSARY. By F. M. DÜENEY. Foreword by W. EgLINGTON, Founder and Editor of "The British Export Gazette." In demy 8vo, cloth gilt, 254 pp. 6s. net.

THE PRINCIPLES OF MARINE LAW. (See p. 7.)

CASE AND FREIGHT COSTS. The Principles of Calculation relating io the Cost of, and Freight on, Sea or Commercial Cases. By A. W. E. Crosfield. In crown $8 \mathrm{vo}$, cloth, 62 pp., 2s. net. 


\section{BANKING AND FINANCE}

110NEY, EXCHANGE AND BANKING, in their Practical, Theoretical, and Legal Aspects. A complete Manual for Bank Officials, Business Men, and Students of Commerce. By H. T. EAston, Associate of the Institute of Bankers. Second Edition, Revised. In demy 8vo, cloth gilt, 312 pp., 6.. net.

IOREIGN EXCHANGE AND FOREIGN BILLS IN THEORY AND IN PRACIICE. By W. F. SPALDING, Certificated Associate, Institute of Bankers, etc., etc. Third Edition. In demy 8vo, cloth gilt, 227 pp., 7s. 6d, net.

EASTERN EXCIANGE, CURRENCY AND FINANCE. By the same Author. Third Edition. In demy 8vo, cloth, 375 pp., with 1 coloured and 6 black-and-white full-page plates, 15s. net.

FOREIGN EXCHANGE, A PRIMER OF. By the same Author. In crown 8vo, cloth, 108 pp., 3s. 6d. net.

PRACTICAL BANKING. By J. F. G. BAGSHAw, Certificated Associate of the Institute of Bankers. With chapters on "The Principles of Currency," by C. F. HANNAFORD, Associate" of the Institute of Bankers, and "Bank Book-keeping,' by W. H. PEARD, Member of the Institute of Bankers in Ireland. In demy 8vo, cloth gilt, 397 pp., 7s. 6d. net.

BANK ORGANISATION, MANAGEMENT, AND ACCOUNTS. By J. F. DAvis, D.Lit., M.A., LL.B. (Lond.). In demy 8vo, cloth gilt, 165 pp., 6s. net

BHILS, CHEQUES, AND NOTES. A Handbook for Business Men and Lawyers. Together with the Bills of Exchange Act, 1882, the Amending Act, Bills of Exchange (Crossed Cheques) Act, 1906, and the Bills of Exchange (Time of Noting) Act, 1917. By J. A. Slater, B.A., LL.B. Lond.). Third Edition. 'In demy 8vo, cloth gilt, 214 pp., 6s. net.

BANKERS' SECURITIES AGAINST ADVANCES. By LAWRENCE A. Fogg, Certificated Associate of the Institute of Bankers. In demy 8vo, cloth gilt, 120 pp. 6s. net.

BANKERS' ADVANCES. By F. R. Stead. Edited by Sir John Paget, K.C. In demy 8vo, cloth, 144 pp., 6s. net.

THE EVOLUTION OF THE MONEY IIARKET (1385-1915). An Historical and Analytical Study of the Rise and Development of Finance as a Centralised, Co-ordinated Force. By Ellis T. Powell, LL.B. (Lond.), D.Sc. (Econ., Lond.), Barrister-at-Law. In demy 8vo, cloth gilt, 748 pp., 10s. 6d. net.

SIMPLE INTEREST TABLES. By SIR Wм. Schooling, K,B.E. In crown8vo, cloth gilt, 188 pp., $21 \mathrm{~s}$. net.

TALKS ON BANKING TO BANK ClERKS. By Harold E. Evans, Certificated Associate of the Institute of Bankers. In crown 8vo, cloth, 152 pp., 2s. 6d. net.

DICTIONARY OF BANKING. A Complete Encyclopaedia of Banking Law and Practice. By W. Thomson, Bank Inspector. Third Edition, Revised and Enlarged 1919. In crown 4to, half-leather gilt, 642 pp., sos. net.

\section{SECRETARIAL WORK}

THE COMPANY SECRETARY'S VADE MECUM. Edited by PHIIP TOVEY, F.C.I.S. Third Edition. In foolscap 8vo, cloth, 3s. 6d. net. 
SECRETARY'S HANDBOOK. A Practical Guide to the Work and Duties in connection with the Position of Secretary to a Member of Parliament, a Country Gentleman with a landed estate, a Charitable Institution, with a section devoted to the work of a Lady Secretary and a chapter dealing with Secretarial work in general. Edited by H. E. BlaIN, C.B.E. In demy 8vo, cloth gilt, 168 pp., 6s. net.

GUIDE FOR THE COMPANY SECRETARY. A Practical Manual and Work of Reference for the Company Secretary. By ARTHuR Coles, F.C.I.S. Second Edition, Enlarged and thoroughly Revised. With 76 facsimile forms, and the full text of the Companies Acts, 1908 and 1913, the Companies Clauses Act, 1845, Companies (Foreign Interest) Act, 1917, Companies (Particulars as to Directors) Act, 1917, and War Legislation. In demy 8vo, cloth gilt, 432 pp., 6s. net.

COMPANY ACCOUNTS. By the same Author. (See p. 1.)

DICTIONARY OF SECRETARIAL LAW AND PRACTICE. A Comprehensive Encyclopaedia of Information and Direction on all matters connected with the work of a Company Secretary. Fully illustrated with the necessary forms and documents. With Sections on special branches of Secretarial Work. Edited by PHILIP TOVEY, F.C.I.S. With contributions by nearly 40 eminent authorities on Company Law and Secretarial Practice, including : The Rt. Hon. G. N. Barnes, M.P. ; F. Gore-Browne, K.C., M.A. ; A. Crew, F.C.I.S. ; J. P. Earnshaw, F.C.I.S.; M. Webster Jenkinson, F.C.A. ; F. W. Pixley, F.C.A. Third Edition, enlarged and revised. In one volume, cloth gilt, $1011 \mathrm{pp}$., 42s. net.

THE TRANSFER OF STOCKS, SHARES, AND OTHER MARKETABLE SECURITIES. A Manual of the Law and Practice. By F. D. HeAD, B.A. (Oxon.), Barrister-at-Law. Second Edition, Revised and Enlarged. In demy $8 \mathrm{vo}$, cloth gilt, 220 pp., 5s. net.

THE CHAIRMAN'S MANUAL. Being a guide to the management of meetings in general, and of meetings of local authorities, with separate and complete treatment of the meetings of public companies. By GuRDON Palin, Barrister-at-Law, and ERnest Martin, F.C.I.S. In crown 8vo, cloth gilt, 192 pp.. 3s. 6d, net.

HOW TO TÁKE MINUTES. Edited by ERnest Martin, F.C.I.S. Second Edition, Revised and Enlarged. In demy 8vo, cloth gilt, 130 pp., 2s. 6d. net.

WHAT IS THE VALUE OF A SHARE? Tables for readily and correctly ascertaining (1) the present value of shares; and (2) what dividends should be paid annually to justify the purchase or market price of shares. By D. W. Rossiter. In demy 8vo, limp cloth. 20 pp., 28. 6d. net.

PROSPECTUSES: HOW TO READ AND UNDERSTAND THEH. By Philip Tovey, F.C.I.S. In demy 8 vo, cloth, 109 pp., 5s. net.

\section{INCOME TAX}

INCOME TAX AND SUPER-TAX PRACTICE. Incorporating the Consolidation Act of 1918 and the Finance Acts, 1919 and 1920. Fourth Edition. By W. E. SNelling. In demy 8vo, cloth gilt, 15s. net.

INCOME TAX AND SUPER-TAX LAW AND CASES. A Practical Exposition of the Law, for the use of Income Tax Officials, Solicitors, Accountants, etc. Fourth Edition (in the press). By W. E. SNeling.

COAL MINES EXCESS PAYMENTS, Guarantee Payments and Levies for Closed Mines. By W. E. Snelling. Demy 8vo, cloth gilt, 176 pp., 12s. 6d. net. 
LXCESS PROFITS (Including Excess J̈Lineral Rights) DUTY, and Levies under the Hunitions of War Ads. Incorporating the Provisions of the Income Tax Acts made applicable by Statute and by Regulation, the provisions of the Finance Act, 1920, and also the Regulations of the Commissioners of Inland Revenue, and of the Minister of Munitions. By W. E. Snelling. Sixth Edition, Revised and Enlarged. In demy 8 vo, cloth gilt, 516 pp., 21 s. net.

SUPER TAX TABLES. By G. O. PARsons. 16 pp., 1s. net.

\section{ECONOMICS}

ECONOHIC GEOGRAPHY. By J. McFarLane, M.A., M.Com. In demy 8vo, cloth gilt, 568 pp., with 18 illustrations, $10 \mathrm{~s}$. 6d. net

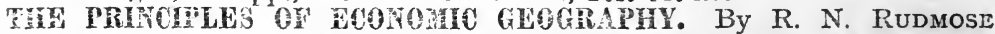
Brown, D.Sc., Lecturer in Geography in the University of Sheffield. In demy 8vo, cloth gilt, 223 pp., 10s. 6d. net.

OUTLINES OF THE ECONOHIC IISTORY OF ENGLAND. A Study in Social Development. By H. O. Meredith, M.A., M.Com., Fellow of King's College, Cambridge. In demy $8 \mathrm{vo}$, cloth gilt, 376 pp., 7s. 6d. net.

THE UISTORY AND ECONOHICS OF TRANSPORT. BY ADAM W. KIRKaldy, M.A., B.Ljtt., Oxford ; M.Com., Birmingham; and Alrred Dudley Evans. In demy 8vo, cloth gilt, 348 pp., 1 is. net.

TUE ECONOMICS GF TELEGRAPHS AND TELEPIONES. BY JOHN LEP, M.A., Traffic Manager, Post Office Te?egraphs. In crown 8vo, cloth gilt, 92 pp., 2s. 6t, net.

INDUSTRY AND FINANCE. (Supplementary Volume.) Edited by ADAм W. KIRKALDY, M.A., B.Litt., M.Com. Deals with the results of inquiries arranged by the Section of Economic Science and Statistics of the British Association. In demy 8vo, cloth, 5s. net.

TALKS WITH WORIKERS. On Wealth, Wages and Production. In crown 8vo., 124 pp,, limp cloth, 2s. net.

\section{ADVERTISING AND SALESMANSHIP}

TIL CRAFT OF SILENT SALESMANSHIP. A Guide to Advertisement Construction. By C. Maxwell Tregurtha and J. W. Frings. Size, $6 \frac{1}{2}$ in. by $9 \frac{1}{4}$ in., cloth, 98 pp., with illustrations. 5s. net.

THE NEW BUSINESS. A Handbook dealing with the Principles of Advertising, Selling, and Marketing. By HARry TIPPER, President, Advertising Men's League, New York. In demy 8vo, cloth gilt, 406 pp., 8s. 6d. net.

SALESIIANSHI': By W. A. CorbIoN and G. E. Grimsdale. In crown 8vo, cloth, 166 pp.. 2s. 6d. net.

PRACTICAL SALESMANSHIP. By N. C. Fowler, Junr. In crown 8vo. 337 pp., 7s. 6d. net.

COHMEPCIAL TRA TELLING. By Albert E. BuLl. In crown 8vo, clotb gilt. 174 pp., 3s. 6l. net.

THEORY AND PRACTICE OF ADVERTISING. By W. DILl ScotT, Ph.D. In large crown 8vo, cloth, with 61 illustrations, 240 pp., 7s. 6d. net.

TIE PSYCHOLOGY OF ADVERTISING. By the same Author. In large crown 8vo, cloth, with 67 illustrations, 282 pp., 7s. 6d. net.

ADVERTISING AS A BUSINESS FORCE. By P. T. CHERINGTON. In demy 8vo, cloth, 586 pp., 8s. 6d. net.

HOW TO ADVERTISE. By G. French, Editor of the "Advertising News." In crown 8 vo., 8s. 6d. net.

THE MANUAL OF SUCCESSFUL STOREKEEPING. By W. A. HotchKIN. In demy 3vo, 298 pp., 8s, 6d, net, 
ADS. AND SALES. By Herbert N. Casson. In demy 8vo, cloth, $167 \mathrm{pp}$. 8s. 6d. net.

THE PRINCIPLES OF PRACTICAL PUBLICTTY. By Truman A. De Weese. In large crown 8vo, cloth, with 43 illustrations, 266 pp., 7s. 6d. net.

\section{LAW}

HERCANTIL LAW. By J. A. Slater, B.A., LL.B. A practical exposition for Law Students, Business Men, and Advanced Classes in Commercial Colleges and Schools. Fourth Edition. In demy 8vo, cloth gilt, 464 pp., 7s. 6d. net.

CODIPANIES ANI) COMPANY LAW. Together with the Companics (Consolidation) Act, 1903, and the Act of 1913. By A. C. Cownell, LL.B. (Lond.), of the Middle Temple, Barrister-at-Law. Sccond Edition, Revised. In demy $8 v 0$, cloth gilt, 348 pp., Gs. net.

COHPANY CASE LAW. By F. D. HEAD, B.A. (Oxon.), Barrister-at-Law. In demy 8 vo, cloth gilt, 314 pp., 7s. Gd. net.

THE LAW OF CARRIAGE. By J. E. R. Stiphens, B.A., of the Middle Temple, Barrister-at-Law. In deiny $8 v o$, cloth gilt, 340 pp., ss. net.

THE LA W RELATING TO TII CARKIAGE BY IAND OF PASSENGERS, ANHALS, AND G00DS. By S. W. ClARKE, Barrister-at-Law. In demy $8 \mathrm{vo}$, cloth gilt, $350 \mathrm{pp}$., 7@. 6d, net.

INCOHE TAX AND SUPFPETX HiY ATD CASES. (See p. 5.)

THE IAW RELATING TO SECBET COHMISSIONS AND BRIBES (Christmas Boxes, Gratuities, Tips, etc.) ; The Prevention of Corruption Acts, 1906 and 1916. By Albert CRew, Barrister-at-Law; Lee Prizeman of Gray's Inn. Second Edition. In demy 8vo, cloth gilt, 252 pp., 16s. 6i. net.

BANKRUPTCY, DEEDS OF ARRANGEHENT, AND BILLS OF SALE. By W. Valentrne Ball, M.A., and G. Mills, B.A., Barristers-at-Law. Third Edition, Revised in accordance with the Bankruptcy and the Deeds of Arrargement Acts, 1914. In demy 8vo, 364 pp., 5s. net.

PRINCIPLES OF MARINE IAW. BY LAWRENCE DUCKWORTH, Barristera!-Laथ. Third Edition, Revised. In demy 8 vo, about 400 pp. 7s. 6i. net.

GUIDE TO THE IAW OF LICENSING. The Handbook for all Licenceholders. By J. Wells Thatcher, Barrister-at-Law. In demy 8vo, cloth gilt, 200 pp., 5s. net.

RAILWAY (REBATES) CASE LAW. By Geo. B. Lissenden. In demy 8 vo, cloth gilt, 450 pp., $10 \%$. 6h, net.

PARTNERSHIP LAW AND ACCOUNTS. By R. W. Holland, O.B.E., M.A., M.Sc., LL.D., Barrister-at-Law. In demy 8vo, cloth gilt, 159 pp., is. net.

THE IAW OF CONTRACT. By the same author. In demy 8vo, cloth, $123 \mathrm{Fp}$., 5.3. net.

THE LA W RelatiNg To The CiILD: Its Protection, Education, and Employment. With Introduction on the Laws of Spain, Germany, France and Italy; and Bibliography. By the same author. In deny 8vo, 166 pp., 5s. net.

GUIDE TO THE REGISTRATION OF BUSINESS NAMES ACT, 1916. By KENNETH BROWN, Solicitor. In crown 8vo, paper boards, is, net.

CONVEYANGING. By E. A. Cope. In crown 8vo, cloth, 206 pp., 3s. 6d. net.

WILLS, EXECUTORS, AND TRUSTEES. By J. A. Slater, B.A., LL.B. With a chapter on Intestacy. In foolscap 8vo, cloth, 122 pp., 2s. 6d. net.

INHABITED HOUSE DUTY. By W. E. SNELLING, In deny 8vo, cloth gilt, 356 pp., 12s. Gd, net. 
THE LAW OF REPAIRS AND DILAPIDATIONS. By T. Cato Worsfold, M.A., LL.D. In crown 8vo, cloth gilt, 104 pp., 3s. 6d. net.

THE LAW OF EVIDENCE. By W. NEmbHaRd HibBert, LL.D. Barristerat-Law. Third Edition, Revised. In crown 8vo, 120 pp., 7s. 6d. net.

THE LAW OF PROCEDURE. By the same Author. In demy 8vo, cloth gilt, 122 pp., 5s. net.

BILLS, CHEOUES, AND NOTES. (See page 4.)

THE HISTORY, LAW, AND PRACTICE OF THE STOCK EXCHANGE. (See page 3 )

\section{BUSINESS REFERENCE BOOKS}

ISUSINESS MAN'S ENCYCLOPAEDIA AND DIC'IONARY OF COMMERCE. A reliable and comprehensive work of reference on all commercial subjects, specially designed and written for the busy merchant, the commercial student, and the modern man of affairs. Edited by J. A. Slater, B.A., LL.B. (Lond.) Assisted by upwards of 50 specialists as contributors. With numerous maps, illustrations, facsimile business forms and legal documents, diagrams, etc. In 4 vols., large crown 4 to (each $450 \mathrm{pp}$.), cloth gilt, $f 4$ 4s. 0d. net.

BUSINESS MAN'S GUIDE. Seventh Revised Edition. With French, German, Spanish and Italian equivalents for the Commercial Words and Terms. Edited by J. A. Slater, B.A., LL.B. (Lond.). The work includes over 2,000 articles. In crown $8 v o$, cloth, 520 pp., 6s. 6l. net.

COMMERCIAL ARBITRATIONS. By E. J. PARRY, B.Sc., F.I.C., F.C.S. An invaluable guide to business men who are called upon to conduct arbitrations. In crown $8 v o$, cloth gilt, $8 \mathrm{~s}$. 6d. net.

PERSONAL EFWCILNCY IN BUSINESS. By E. E. PURINGTON. In crown 8vo, cloth gilt, 341 pp., 7s. 6d. net.

DICTIONARY OF COMMERCIAL CORRESPONDENCE IN SEVEN LAN. GUAGES : ENGLISH, FRENCH, GERMAN, SPANISH, ITALHA, PORTUGUESE AND RUSSIAN. In demy 8vo, cloth, 718 pp., 12s.6d. net. Third Edition.

A MANUAL OF DUPLICATING METHODS By W. Desborough. In demy 8 vo, cloth, 90 pp., illustrated, 2 s. 6u. net.

COMHON COMMODITIES AND INDUSTRIES SEIRIES. Each book in crown 8vo, cloth, illustrated, 3s. net. Volumes already published on Tea, Coffee, Sugar, 0ils, Wheat, Rubber, Iron and Steel, Copper, Coal, Timber, Cotton, Silk, Wool, Linen, Tobaceo, Leather, Clays, Paper, Soap, Glass, Gums and Resins, The Motor Industry, Boct and Shoe Industry, Gas and Gas Making, Petrolenm, Salt, Furniture, Coal Tar, Knitted Fabries, Zine, Asbestos, Photography, Silver, Carpets, Paints and Varnishes, Cordage and Cordage Hemp and Fibres, Acids and Alkalis, Gold, Electricity, Butter and Cheese, Aluminium, The British Corn Trade, Engraving, Lead, Stones and Quarries, Clotling Trades Industry, Modern Explosives, Electric Lamp Industry, Perfumery, Ice and Cold Storage, Telegraphy Telephony and Wireless.

\section{BUSINESS ORGANISATION AND MANAGEMENT.}

A Monthly Magazine of High Standard for Business Men.

Price 1s. 6d. Post Free, 1s. 9d. Annual Subscription 18s.

COMPLETE LIST POST FREE ON APPLICATION

Sir Isaac Pitman \& Sons, Ltd., Parker Street, Kingsway, W.C.2

And at Bath, Melbourne, Toronto and New York 
. 


\section{UNIVERSITY OF CALIFORNIA LIBRARY BERKELEY}

Return to desk from which borrowed.

This book is DUE on the last date stamped below.

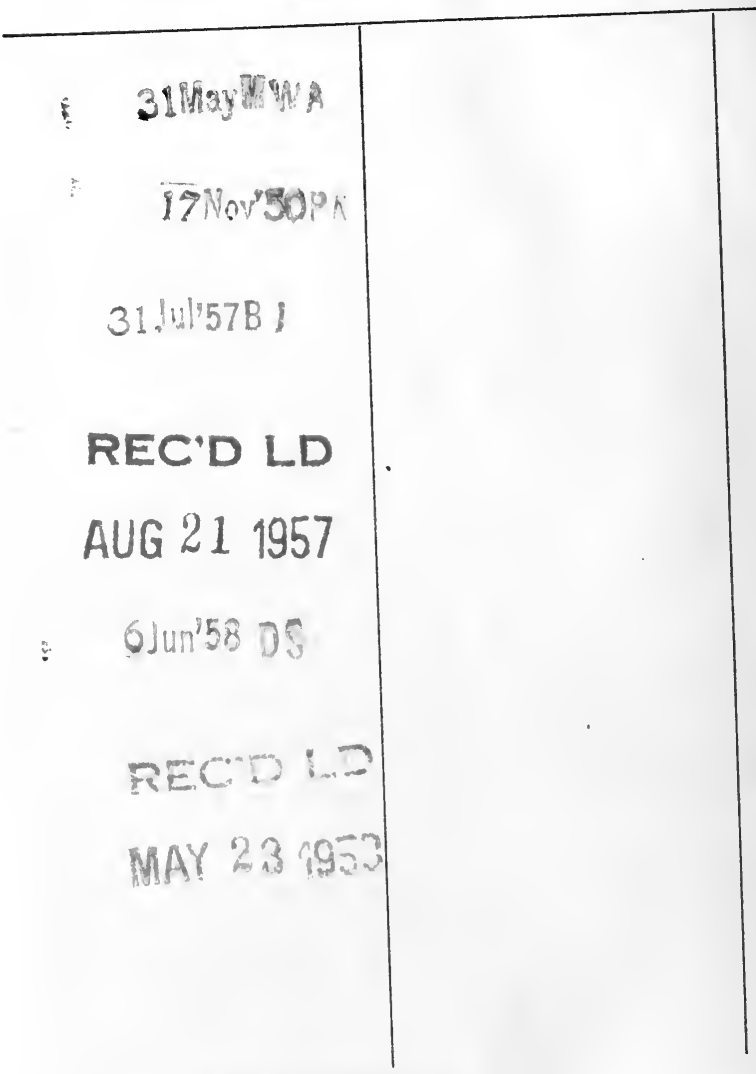

LD 21-100m-9,'48(B399s $16 \lcm{476}$ 
$35^{2}$

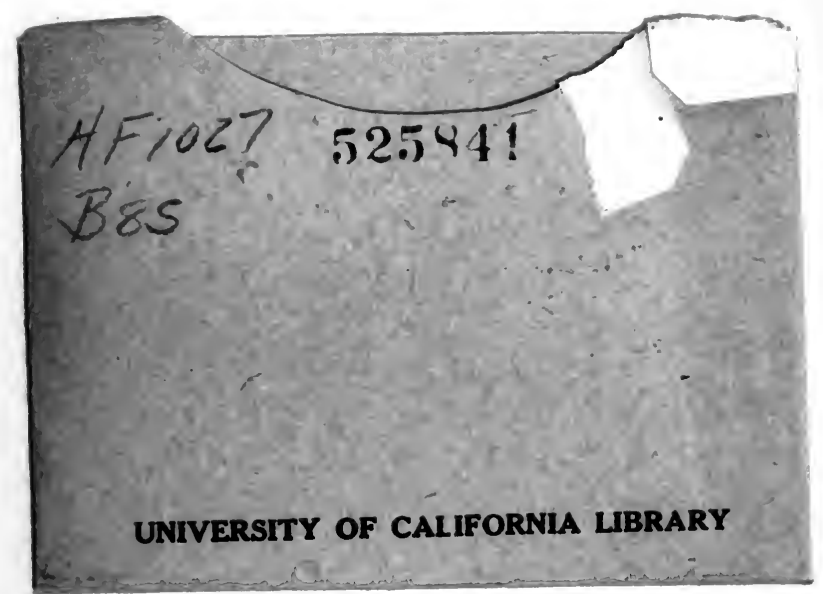


